BRUNO MACIEL DOS SANTOS

\title{
A UTILIZAÇÃO DE PRECATÓRIOS COMO FORMA DE EXTINÇÃO DE CRÉDITOS TRIBUTÁRIOS
}

Faculdade de Direito da Universidade de São Paulo São Paulo - 2013 
BRUNO MACIEL DOS SANTOS

\title{
A UTILIZAÇÃO DE PRECATÓRIOS \\ COMO FORMA DE EXTINÇÃO DE \\ CRÉDITOS TRIBUTÁRIOS
}

\begin{abstract}
Dissertação de mestrado apresentada ao Departamento de Direito Econômico, Financeiro e Tributário da Faculdade de Direito da Universidade de São Paulo, na subárea de Direito Tributário, como requisito parcial para obtenção de título de Mestre, sob a orientação do Professor Doutor Roberto Quiroga Mosquera.
\end{abstract}

Faculdade de Direito da Universidade de São Paulo

São Paulo - 2013 
Santos, Bruno Maciel dos.

A utilização de precatórios como forma de extinção de créditos tributários São Paulo, 2013.

Dissertação apresentada à Banca Examinadora do Departamento de Direito Econômico, Financeiro e Tributário da Faculdade de Direito da Universidade de São Paulo, na subárea de Direito Tributário, como requisito parcial para obtenção de título de Mestre.

Orientador: Professor Doutor Roberto Quiroga Mosquera

1. Precatórios. 2. Extinção do crédito tributário. 3. Pagamento. 4. Compensação. 5. Execução fiscal. 
BANCA EXAMINADORA 
Dedico este trabalho aos meus pais

Thaís e Maciel, às minhas irmãs

Bianca e Aline, e aos meus irmãos de coração, Eric e Fernando. À Mayara, pelo amor que me fortalece diariamente. Ao meu sobrinho Breno, que se mostrou um gigante com apenas $600 \mathrm{~g}, 30 \mathrm{~cm}$ e 24 semanas de vida! 


\section{AGRADECIMENTOS}

No momento em que salvamos aquela que pretensamente seria a última versão da dissertação a ser apresentada aos professores que comporão a banca examinadora, lembramo-nos daqueles que foram essenciais ao desenvolvimento deste trabalho, a quem gostaria de registrar meus sinceros agradecimentos.

Ao professor Roberto Quiroga Mosquera, expoente nacional tanto na advocacia como na academia, agradeço não só a oportunidade de tê-lo como orientador, mas principalmente pelo convívio nestes últimos anos, nos quais recebi valiosos ensinamentos que guardarei por toda vida.

Aos professores José Maurício Conti e Fernando Facury Scaff pelos precisos e preciosos apontamentos, sem os quais não seria possível aprumar o presente estudo.

Ao Paulo Camargo Tedesco, dedicado revisor, notável jurista e amigo verdadeiro para todas as horas.

Aos Procuradores do Estado de São Paulo Eduardo José Fagundes e Alexandre Aboud pelo aprendizado diário e, principalmente, por deixarem o ambiente de trabalho prazeroso e propício ao desenvolvimento deste estudo.

Muito obrigado a todos! 


\section{RESUMO}

A presente dissertação focaliza a utilização do precatório judicial como meio de extinção do crédito tributário. Parte-se da seguinte hipótese: é possível a utilização de precatórios como forma de extinção do crédito tributário? Em quais situações? Para que se possa responder com segurança às indagações acima, são analisadas as modalidades de extinção do crédito tributário previstas no Código Tributário Nacional, especificamente o pagamento e a compensação, apontando-se os seus requisitos essenciais e as limitações impostas pelo ordenamento jurídico para a realização de ambos. Com suporte nessas considerações são fixadas as premissas que servirão para o enfrentamento das teses envolvendo a extinção dos créditos tributários por meio de precatórios. A partir disso, adentra-se ao estudo dos precatórios, desde a sua origem no Direito Constitucional Brasileiro, até o seu atual regramento na Constituição da República. São também estudadas as mudanças empreendidas após a promulgação da Constituição Federal de 1988, com destaque para as Emendas Constitucionais $n^{\circ} 30$ de 2000 e 62 de 2009. Isso porque as referidas emendas instituíram, respectivamente, o parcelamento decenal e o regime especial de pagamento de precatórios vencidos, que ensejaram as grandes questões em matéria tributária que são enfrentadas nesta oportunidade, como a utilização de precatórios em compensações ou como garantia da execução fiscal. Ao final do trabalho são expostas as conclusões obtidas.

PALAVRAS-CHAVE: Constituição; Emenda Constitucional; Precatório; Código Tributário Nacional; Pagamento; Compensação; Execução Fiscal. 


\begin{abstract}
This dissertation focuses on the Court-Ordered debt payment to settle taxes. Starts with the following hypothesis: it is possible to use a Court-Ordered debt payment for pay a tax debit? In what situations? To respond this questions safely, was studied the conditions for the payment of tax debit, specifically the payment in the tax law and compensation, pointing to their requirements and limitations imposed by law. This rules will used to be set the possibility to pay a tax debit with the judicial order. After this, will be studied the court ordered in the Brazilian Constitutional Law and the changes performed, especially the Constitutional Amendments No. 30 of 2000 and 62 of 2009. That's because those amendments introduced like the special parceling for payment the public debt are the focus of the the major questions concerning tax matters that were worked at this opportunity. At the end of this work will be exposed the conclusions.
\end{abstract}

KEYWORDS: Constitution; Constitutional Amendments; Court-ordered debt payment; Tax Law; payment; compensation; lawsuit. 


\section{LISTA DE ABREVIATURAS E SIGLAS}

ADC - Ação Declaratória de Constitucionalidade

ADI - Ação Direta de Inconstitucionalidade

ADCT - Ato das Disposições Constitucionais Transitórias

AgR. - Agravo Regimental

AI - Agravo de Instrumento

Art. - Artigo

C.F. - Constituição Federal

CPC - Código de Processo Civil

CTN - Código Tributário Nacional

E.C. - Emenda Constitucional

ECT - Empresa Brasileira de Correios e Telégrafos

EResp - Embargos em Recurso Especial

FDICs. - Fundos de Direitos Creditórios

ICMS - Imposto sobre a Circulação de Mercadorias e sobre Prestações de Serviços de Transporte Interestadual e Intermunicipal e de Comunicação

IPI - Imposto sobre Produtos Industrializados

IPVA - Imposto sobre a Propriedade de Veículos Automotores

Min. - Ministro

RE - Recurso Extraordinário

Rel. - Relator(a)

REsp - Recurso Especial

RPV - Requisição de Pequeno Valor

STF - Supremo Tribunal Federal

STJ - Superior Tribunal de Justiça

TJ - Tribunal de Justiça 


\section{SUMÁRIO}

\section{INTRODUÇÃO}

1 A FORMAÇÃO E A EXTINÇÃO DO CRÉDITO TRIBUTÁRIO …............................12

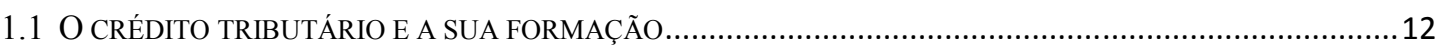

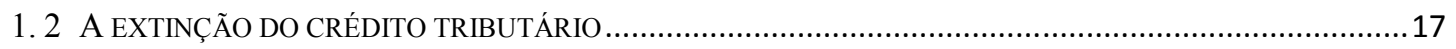

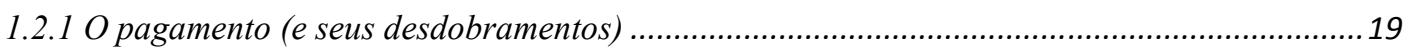

1.2.2 A compensação tributária e a repetição do indébito tributário...............................................25

1.2.3 A compensação tributária com outros créditos (créditos não relacionados ao indébito tributário)

20 PAGAMENTO DA DÍVIDA PÚBLICA DECORRENTE DE DECISÃO JUDICIAL

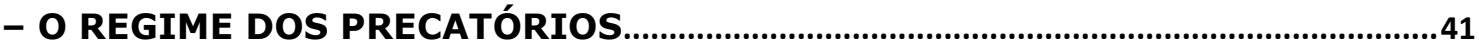

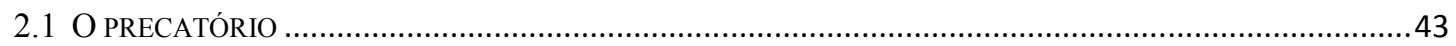

2.2 O PRECATÓRIO NO DiREITO CONSTITUCIONAL BRASILEIRO ………………………........................46

2.2.1 Evolução constitucional da disciplina do precatório ..............................................................47

2.2.2 O regime dos precatórios na Constituição da República de 1988...........................................51

2.2.3 O estoque de precatórios, o poder liberatório para pagamentos de tributos e a criação de um

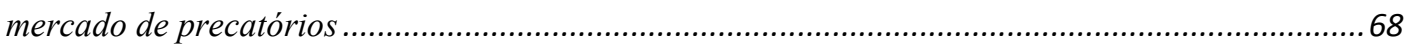

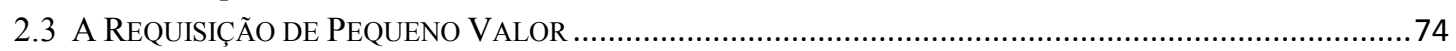

\section{A UTILIZAÇÃO DE PRECATÓRIOS COMO FORMA DE EXTINÇÃO DE} CRÉDITOS TRIBUTÁRIOS.

3.1 O PRECATÓRIO E A EXTINÇÃO DO CRÉDITO TRIBUTÁRIO PELO PAGAMENTO ......................................79

3.2 O PRECATÓRIO E A COMPENSAÇÃO TRIBUTÁRIA................................................................................8 82

3.2.1. A compensação entre créditos tributários e precatórios que não sejam constitucionalmente dotados de poder liberatório para o pagamento de tributos...

3.2.2 A compensação com fundamento no artigo $78, \S 2^{\circ}$ do Ato das Disposições Constitucionais

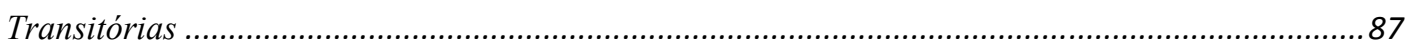

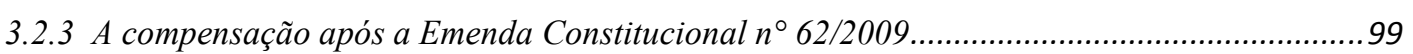

3.2.4 A compensação e os precatórios alimentares.................................................................... 101

3.2.5 A compensação entre pessoas jurídicas diferentes ............................................................... 105

3.2.6 A compensação do artigo 100, $\S 9^{\circ}$ da Constituição Federal.................................................108

3.3 O PRECATÓRIO COMO GARANTIA DA EXECUÇÃO FISCAL ..............................................................118

3.3.1 O regramento da garantia à execução fiscal ...........................................................................118

3.3.2 A natureza do precatório oferecido à penhora na execução fiscal........................................120

3.3.3 O problema da efetivação da garantia ............................................................................... 122

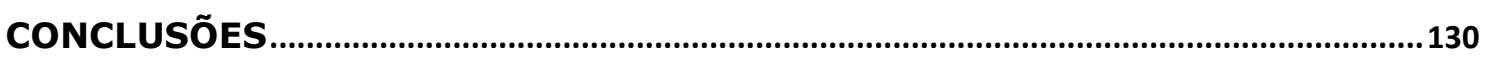

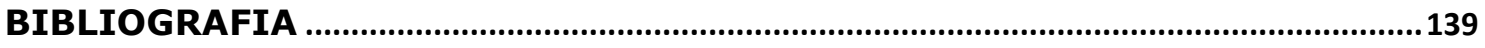

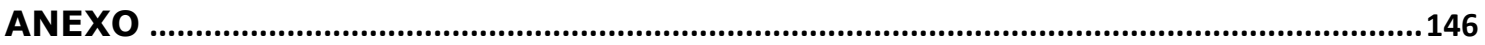




\section{INTRODUÇÃO}

A presente dissertação parte da seguinte hipótese: é possível a utilização de precatórios como forma de extinção do crédito tributário? Se sim, em quais situações?

Tal assunto mostra-se instigante pelo fato de que, ao nosso sentir, ainda não havia sido tratado deforma sistematizada pela doutrina nacional.

Essa percepção restou evidenciada com a edição de Emenda Constitucional $n^{\circ} 62$, de 9 de dezembro de 2009, que além de reavivar antigas discussões, ensejou o desenvolvimento de novas teses, tornando o tema extremamente atual.

Com efeito, o Brasil adotou a sistemática dos precatórios como forma de pagamento da dívida pública decorrente de decisões judiciais desfavoráveis à Fazenda Pública que tenham transitado em julgado.

Referida modalidade de pagamento, em linhas gerais, garante que a dívida pública seja quitada sem abalo ao orçamento, já que estará nele inserida, como também resguarda o credor de qualquer preferência ao recebimento que não as expressamente previstas na Constituição de República, pois, no regime dos precatórios, a dívida é solvida seguindo uma ordem cronológica de pagamento.

Ocorre que, ao longo dos anos, diversos fatores de ordem política, econômica e jurídica contribuíram para que a dívida pública decorrente das decisões judiciais não fosse quitada no prazo constitucionalmente previsto, formando verdadeiro "estoque" de precatórios.

Assim, buscando solucionar o que alguns consideravam um verdadeiro "calote" público, foram adotadas algumas alternativas, como o parcelamento dos precatórios, previsto inicialmente no artigo 33 do Ato das Disposições Constitucionais Transitórias e, posteriormente, nas Emendas Constitucionais 30/2000 e 62/2009 ${ }^{1}$.

\footnotetext{
${ }^{1}$ Nessa linha, Carlos Valder do Nascimento assevera que: "Tem sido recorrente a inserção, por meio de emendas, de normas infraconstitucionais na Constituição Federal. [...] Com esse mesmo propósito, acaba de ser aprovada a Emenda Constitucional n ${ }^{\circ}$ 62/2009, que implantou uma nova sistemática para o pagamento de precatórios, que logo recebeu o tratamento adequado, isto é, de emenda do calote. (NASCIMENTO, Carlos Valder do; FILHO, Marçal Justen. Emenda dos precatórios: fundamentos de sua inconstitucionalidade. Belo Horizonte: Fórum, 2010, p. 11-12).
} 
Estes dois últimos parcelamentos de precatórios, introduzidos pelas citadas Emendas Constitucionais, suscitaram diversas discussões doutrinárias e jurisprudenciais, pois neles foi previsto a possibilidade de a Fazenda Pública utilizar a sua "dívida passiva" como forma de extinção dos créditos tributários, sobretudo, por meio de compensações.

E é sobre esse pano de fundo que se desenvolverá o presente estudo.

De início, com vistas à almejada sistematização da matéria em exame, serão fixadas as premissas que servirão para as respostas às indagações acima formuladas, analisando-se a formação e a extinção do crédito tributário, com ênfase no pagamento e na compensação.

Em seguida será estudado o regramento constitucional para o pagamento da dívida pública decorrente de sentença judicial, com destaque para as situações em que se permite a atribuição de poder liberatório ao precatório para o pagamento de tributos.

A partir dessas considerações, serão enfrentadas as questões decorrentes da utilização do precatório como forma de extinção do crédito tributário.

Tais questionamentos vão desde a simples tese de que seria possível o precatório servir como moeda para o pagamento de um tributo, passando pelas compensações e finalizando com o estudo do precatório como garantia da execução fiscal.

Estarão também incluídas nessas discussões as novas controvérsias que surgiram com a Emenda Constitucional n. 62/09, a qual, como já mencionado, promoveu várias alterações tanto no regime jurídico dos precatórios expedidos após a sua edição (artigo 100 da Constituição da República) como para os valores remanescentes dos parcelamentos previstos pelas emendas anteriores, alcunhados de "estoque de precatórios".

Diante do regramento constitucional atualmente vigente, questiona-se, dentre outras coisas, a constitucionalidade da compensação de ofício pela Fazenda Pública devedora (artigo 100, § $9^{\circ}$, da Constituição da República) e a manutenção da vedação da utilização de precatórios alimentares e dos oriundos do saldo remanescente do parcelamento previsto no artigo 33 do ADCT para a quitação de tributos.

Destaca-se que, neste estudo, procurou-se seguir a linha da dogmática jurídica, analisando-se o tema a partir da legislação aplicável, sem olvidar os conceitos doutrinários e jurisprudenciais. 
Ademais, observou-se o método dedutivo de pesquisa, pois, como bem pontua José Souto Maior Borges": "A indução, em qualquer plano do conhecimento, é simplesmente inviável".

Adverte-se, contudo, que não será exaustivo o estudo da formação e extinção do crédito tributário, bem como do próprio regime constitucional e infraconstitucional dos precatórios, sendo apenas apresentados os conceitos que serão adotados para a formulação das respostas às indagações específicas da área tributária.

A ressalva acima é importante não só para a delimitação do objeto da dissertação ora apresentada, como também para que se evite incorrer naquilo que Umberto Eco ${ }^{3}$ denomina de "tese panorâmica".

É importante também observar que o tema exige constante visitação a outros ramos didáticos do Direito, como o Financeiro ${ }^{4}$. Entretanto, buscou-se manter o foco no Direito Tributário $^{5}$, utilizando-se os conceitos e institutos próprios de outras áreas apenas como elemento útil à solução de questões atinentes à área enfocada ${ }^{6}$.

${ }^{2}$ BORGES, José Souto Maior. Obrigação tributária (uma introdução metodológica). 2. ed. São Paulo: Malheiros, 1999. p. 21.

3 "Mas uma coisa é usar um panorama como pano de fundo, e outra é elaborar um quadro panorâmico. Uma coisa é pintar o retrato de um cavalheiro sobre o fundo de um campo cortado por um regato, e outra pintar campos, vales e regatos. Tem de mudar a técnica, tem de mudar, em termos fotográficos, o foco. Partindose de um único autor, o panorama pode afigurar-se um tanto desfocado, incompleto ou de segunda mão." (ECO, Umberto. Como se faz uma tese [Título original: Come si fa uma tesi de láurea, 1932]. trad. Gilson Cesar Cardoso de Souza. 23. ed. São Paulo: Perspectiva, 2010, p. 10.).

${ }^{4}$ Nesse ponto, cabe destacar a importante colocação de Ruy Barbosa Nogueira: "É evidente que em qualquer elaboração científica do Direito Tributário não se pode perder de vista as relações que este ramo mantém com outros ramos do Direito ou com ciências afins. É preciso não esquecer que estamos falando do Direito Tributário como um ramo autônomo, sem perder de vista sua posição, integrado na unidade do Direito. O Direito Tributário é a parte mais desenvolvida e destacada do Direito Financeiro. Toda a atividade financeira do Estado, quando reduzida à categoria jurídica ou submetida à metodologia da Ciência Jurídica, assume o aspecto de Direito Financeiro: é uma ciência jurídica. [...] O direito Tributário é o capítulo destacado do Direito Financeiro e se refere àquela parte da receita que diz respeito ao fenômeno jurídico da relação entre tesouro público e contribuinte." (NOGUEIRA, Ruy Barbosa, Curso de Direito Tributário, 4a . ed. São Paulo: Edição do Autor, sob os auspícios do Instituto Brasileiro de Direito Tributário, 1976, p. 24).

${ }^{5}$ Note-se também, como bem observa Vincenzo Demetrio Florenzano, que as questões envolvendo a sistemática dos precatórios extrapolam o universo jurídico, pois o "não-pagamento de precatório é, sem dúvida, um problema grave que poderíamos classificar como transdisciplinar complexo, sendo ao mesmo tempo jurídico, econômico e social. É um problema jurídico, porque o não-pagamento dos precatórios configura um descumprimento de decisões judiciais transitadas em julgado. Ora, se o próprio Estado não cumpre as decisões judiciais, não se pode sequer falar em Estado de Direito. É também, no entanto, um problema econômico, porque afeta o desenvolvimento da atividade econômica e diz respeito à alocação de recursos escassos. É, ainda, um problema social, porque envolve a distribuição e aplicação de recursos públicos. (FLORENZANO, Vincenzo Demetrio. A emenda constitucional n. 30, de 13.9.2000, sob a perspectiva da análise econômica do Direito. In: VAZ, Orlando (Coord.). Precatórios: problemas e soluções. Belo Horizonte: Del Rey, 2005. p. 217.).

${ }^{6}$ Nessa linha observa Paulo de Barros Carvalho: "É tarefa sobremodo árdua traçar os lindes da área que interessa ao estudo do Direito Tributário, mesmo que o cientista se proponha a fazê-lo para efeitos exclusivamente didáticos. E o motivo dessa dificuldade emerge cristalino, assente que parece estar o 
Por fim, não obstante o tema seja comum a todas as esferas da federação, objetivouse, para fins metodológicos, manter o foco no Estado de São Paulo, principalmente no que tange ao regime especial de pagamento de precatórios e à compensação, haja vista ser este o Estado com o maior estoque de precatórios ${ }^{7}$.

De todo modo, não se descuidou da legislação federal sobre a matéria, procurandose, da mesma forma, mencionar as legislações de outros Estados e Municípios em diversas passagens.

É claro que o assunto não está por completo abrangido neste estudo, mas acreditamos que tenha sido alcançado o objetivo de apresentá-lo de forma sistemática, o que poderá contribuir para o avanço de sua reflexão acadêmica, além de servir como instrumento prático aos operadores do Direito.

pressuposto da unidade do sistema jurídico. Mesmo a despeito desse pretexto - 'finalidade didática'-, não deixa de ser a cisão do incindível, a secção do inseccionável. A consideração desse fato possivelmente possa explicar a grande dificuldade que a doutrina tem encontrado quando se dispõe ao trabalho de explicitar o setor que se pode designar de tributário, dentro do Direito positivo e, bem assim, de conceituar a matéria que estuda esse objeto, em outras palavras, a ciência do Direito Tributário." (CARVALHO, Paulo de Barros. Teoria da norma tributária. 4. ed. São Paulo: Max Limonad, 2002. p. 78).

${ }^{7}$ Valor dos precatórios incluídos no orçamento e não pagos - período de referência 2011 - (Data-base 31/12/2011): R\$ 14.719.671.198,16. Disponível em: <http://www.contaspublicas.caixa.gov.br/ sistncon_internet $/$ consultaDeclaracoes.do?acao $=$ imprimir\&numeroDeclaracao $=366639>$. Acesso em: 23 nov. 2012). Em 30/04/2012, o estoque de precatórios no Estado de São Paulo ultrapassava 19 bilhões de reais. (Fonte: Secretaria da Fazenda. Disponível em: <http://www.fazenda.sp.gov.br/contas/ precatorios/precatorios_estoque.pdf $>$. Acesso em 22 nov. 2012). 


\section{A FORMAÇÃO E A EXTINÇÃo DO CRÉDITO TRIBUTÁRIO}

Para que se possa adentrar a discussão acerca da utilização de precatórios na extinção de créditos tributários, mostra-se imprescindível que se determine como se origina um crédito tributário, bem como que se estabeleça quais são as hipóteses legalmente previstas para sua extinção, identificando, dentre estas, aquelas em que se permitiria a utilização de precatórios. É o que se passa a fazer.

\subsection{O crédito tributário e a sua formação}

Ocorrido no mundo fenomênico um fato previsto na hipótese de incidência de uma norma geral e abstrata instituidora de tributo (fato gerador), e mediante o relato desse evento em linguagem competente (lançamento) ${ }^{8 / 9}$, instalar-se-á uma relação obrigacional de natureza tributária que imporá ao sujeito passivo o dever de entregar certa quantia em dinheiro aos cofres públicos. Essa quantia em dinheiro, objeto da prestação da relação obrigacional instaurada, denomina-se crédito tributário.

Assim, pode-se conceituar o crédito tributário como o objeto da prestação da relação jurídico-tributária, instaurada com a verificação do fato jurídico tributário previsto no critério material do antecedente de uma regra-matriz de incidência tributária, que terá

\footnotetext{
${ }^{8}$ Paulo De Barros Carvalho assim define lançamento tributário: "é o ato jurídico administrativo, da categoria dos simples, constitutivos e vinculados, mediante o qual se insere na ordem jurídica brasileira u a norma individual e concreta, que tem como antecedente o fato jurídico tributário e, como consequente, a formalização do vínculo obrigacional, pela individualização dos sujeitos ativo e passivo, a determinação do objeto da prestação, formado pela base de cálculo e correspondente alíquota, bem como pelo estabelecimento dos termos espaço-temporais em que o crédito há de ser exigido." (Curso de Direito Tributário. 22. ed. São Paulo: Saraiva, 2010. p. 458). Nessa esteira também é a definição de Eurico Marcos Diniz de Santi, para quem "lançamento" é "o ato-norma administrativo que apresenta estrutura hipotético-condicional, associando à ocorrência do fato jurídico tributário (hipótese) uma relação jurídica intranormativa (consequência), que em tem por termos o sujeito ativo e o sujeito passivo, e por objeto a obrigação deste em prestar a conduta de pagar quantia determinada pelo produto matemático da base de cálculo pela alíquota". (Lançamento tributário. 3. ed. São Paulo: Saraiva, 2010, p. 114-115).

${ }^{9}$ São três as modalidades de lançamento previstas no Código Tributário Nacional (artigos 147 a 150): (i) direto ou de ofício, (ii) misto, ou por declaração e (iii) lançamento por homologação. A distinção entre as modalidades de lançamento está relacionada à participação do sujeito passivo (contribuinte, substituto ou responsável) na elaboração do lançamento. Na primeira hipótese (ofício), toda a atividade é realizada pela Administração Tributária, sendo o sujeito passivo apenas notificado do lançamento. Já na segunda (declaração), o lançamento é realizado com base nas informações prestadas pelo contribuinte. Ou seja, o lançamento só será levado a efeito se o Fisco obtiver as informações que devem ser prestadas pelo contribuinte. Na última hipótese, por homologação, o sujeito passivo deverá identificar a hipótese de incidência, calcular o montante devido, realizar o pagamento e aguardar a sua homologação.
} 
como sujeito ativo o ente político a quem foi outorgada a competência tributária e como sujeito passivo o contribuinte, ou responsável tributário, que deverá adimplir a referida obrigação.

A relação obrigacional de índole tributária, assim como as demais relações obrigacionais, somente se instalará se presentes todos os seus elementos, a saber: sujeito ativo, sujeito passivo e objeto da pretensão.

Logo, no instante em que verificado o fato jurídico tributário serão imediatamente determinados os componentes da obrigação tributária. Não existe obrigação com apenas dois de seus componentes. Do mesmo modo, extinto seu objeto (crédito tributário), extinta estará a obrigação tributária.

Assim, não há dúvida de que o crédito tributário nasce com a obrigação principal e dela faz parte ${ }^{10}$.

Tal assertiva explicita a posição tomada acerca das discussões que giram em torno da natureza e eficácia do lançamento, em virtude das possíveis interpretações dos artigos 139, 142, caput, 144, caput e 156 do Código Tributário Nacional, as quais, embora instigantes e com grande repercussão doutrinária, não interferem no estudo ora proposto e não serão analisadas nesta oportunidade ${ }^{11}$.

Entretanto, apesar de não serem enfrentadas as questões atinentes à natureza e à eficácia do lançamento, bem como aquelas pertinentes à constituição definitiva do crédito

${ }^{10}$ Cf. SCHOUERI, Luís Eduardo. Direito tributário. São Paulo: Saraiva, 2011. p. 527-528; CARVALHO, Paulo de Barros. Curso de direito tributário. 22. ed. São Paulo: Saraiva, 2010, p. 520; CONRADO, Paulo Cesar. Compensação tributária e processo. 2. ed. São Paulo: Quartier Latin, 2010. p. 59-60; e COÊLHO, Sacha Calmon Navarro. Liminares e depósitos antes do lançamento por homologação: decadência e prescrição. 2.ed. São Paulo: Dialética, 2002. p. 11. Em sentido oposto, defendendo que a obrigação e o crédito tributário teriam origem em momentos distintos, Hugo de Brito Machado: "Em princípio o fato se rege pela lei vigente na data de sua ocorrência. Assim, é importante sabermos quando ocorre, vale dizer, quando nasce a obrigação tributária, para que se possa saber qual a lei, se tiver havido mudança, a ela se aplica. E para tanto é importante termos em mente que na terminologia adotada pelo Código Tributário Nacional a obrigação tributária e o crédito tributário não se confundem e nascem em momentos distintos. [...] A rigor, a relação jurídica surge com a ocorrência do fato previsto em lei como necessário e suficiente para produzi-la. E assim acontece com a relação obrigacional tributária. Nada impede, porém que o legislador postergue o surgimento da exigibilidade para um momento posterior , como afirmou Alfredo Augusto Becker, antes do advento do Código Tributário Nacional". (Comentários ao código tributário nacional. v. III. São Paulo: Atlas, 2005. p.100-101).

${ }^{11}$ A discussão mencionada tem como ponto central a natureza do lançamento, se constitutiva ou declaratória do crédito tributário, pois o artigo 139 do CTN dispõe que "o crédito tributário decorre da obrigação principal e tem a mesma natureza desta", e o artigo 142, caput, estabelece que à autoridade administrativa compete "constituir" o crédito tributário por meio do lançamento. Para o desenvolvimento deste trabalho nos alinhamos ao posicionamento de que a obrigação e crédito tributário nascem de modo concomitante, tendo o lançamento natureza híbrida, pois declara a relação obrigacional que teve origem com a ocorrência do fato descrito na hipótese de incidência, e permite a imediata instauração da relação obrigacional, por meio da sua natureza constitutiva, servindo o lançamento como uma norma individual e concreta que estabelece a relação jurídica tributária. 
tributário, é relevante reiterar que a instauração de uma relação jurídico-tributária somente é possível se prevista em lei (em sentido estrito - norma geral e abstrata), tendo o lançamento, assim como o autolançamento ${ }^{12}$, a finalidade precípua de verter em linguagem competente um fato ocorrido no mundo fenomênico, viabilizando a incidência da lei com a introdução de uma norma individual e concreta, que identificará os sujeitos da relação e o montante devido a título de tributo.

Posto isso, impende cuidar mais detidamente do vocábulo "tributo", diferenciandoo, para fins metodológicos, do conceito de crédito tributário acima delineado.

Isso porque "tributo" é um termo equívoco, polissêmico, e que pode ser utilizado como sinônimo de crédito tributário. Assim, para que não haja incerteza quanto ao emprego do termo tributo neste estudo, vejamos as seis acepções do vocábulo identificadas por Paulo de Barros Carvalho ${ }^{13}$ para, em seguida, apontar aquela que será adotada. São elas:

$$
\text { “tributo" como quantia em dinheiro; }
$$

12 Estevão Horvath define o termo "autolançamento" como "o ato, ou conjunto de atos do particular, que, materialmente, tem o mesmo conteúdo do lançamento, mas não pode produzir os efeitos próprios deste uma vez que não provém da Administração - a não ser por uma ficção jurídica, ou equiparação ao ato de lançamento, o que ocorrerá no caso de ser confirmado (o autolançamento) pela Administração, expressamente, ou pelo decurso de tempo apto a provocar os efeitos do silêncio positivo do Fisco." (HORVATH, Estevão. Lançamento tributário e “autolançamento". São Paulo: Dialética, 1997. p. 79). $\mathrm{O}$ artigo $5^{\circ} . \S 1^{\circ}$ do Decreto-lei n. 2.124/84 já previa que "o documento que formalizar o cumprimento de obrigação acessória, comunicando a existência de crédito tributário, constituirá confissão de dívida e instrumento hábil e suficiente para a exigência do referido crédito.” Todavia, a viabilidade de constituição do crédito tributário por meio do auto lançamento suscitou diversas discussões doutrinárias, tendo em vista a privatividade da Administração Tributária para a prática do lançamento, nos termos artigo 142 do Código Tributário Nacional. No entanto, tendo em vista que a jurisprudência do Superior Tribunal de Justiça já ratificou a validade dessa forma de constituição do crédito tributário, conforme se constata da súmula 436, que estabelece que "a entrega de declaração pelo contribuinte, reconhecendo o débito fiscal, constitui o crédito tributário, dispensada qualquer outra providência por parte do Fisco" (Precedente da Primeira Seção submetido ao rito do artigo 543-C, do CPC: REsp 962.379/RS, Rel. Ministro Teori Albino Zavascki, julgado em 22.10.2008, DJe28.10.2008), nos mesmo sentido são as decisões que dispensam a atividade de lançamento para a conversão do depósito em renda da Fazenda Pública, nas ações judiciais em que o contribuinte realiza o depósito do montante que entende ser o valor integral do débito para suspender a sua exigência, nos termos do artigo 151, inciso II do Código Tributário Nacional (Precedentes da Primeira Seção: EREsp 464.343/DF, Rel. Min. José Delgado, DJ de 29.10.2007; EREsp 898.992/PR, Rel. Min. Castro Meira, DJ de 27.8.2007; EREsp. n. 671.773-RJ, Primeira Seção, Rel. Min. Teori Zavascki, julgado em23.6.2010). Em sentido contrário, inadmitindo a existência de autolançamento, Marcelo Fortes de Cerqueira: "Não é a homologação um lançamento, nem a auto-imposição é, por si só, modalidade de lançamento. Tem-se lançamento apenas quando o ato de auto-imposição é devidamente homologado. [...] Pensar que o crédito já tivesse constituído, definitivamente, com a auto-imposição, ou que o crédito tivesse sido extinto desde o pagamento antecipado, denunciaria de pronto o equívoco de trabalhar com a concepção de 'auto-lançamento', algo que verdadeiramente não existe em nosso direito positivo" (CERQUEIRA, Marcelo Fortes de. Extinção da obrigação tributária: compensação e repetição do indébito. In: Curso de especialização em direito tributário: estudos analíticos em homenagem a Paulo de Barros Carvalho. Rio de Janeiro: Forense, 2005. p.375).

${ }^{13}$ CARVALHO, Paulo de Barros. Curso de direito tributário. 22. ed. São Paulo: Saraiva, 2010. p.51-55. 
(ii) "tributo" como prestação correspondente ao dever jurídico do sujeito passivo;

(iii) "tributo" como direito subjetivo de que é titular o sujeito ativo;

(iv) “tributo" como sinônimo de relação jurídica tributária;

(v) "tributo" como norma jurídica tributária; e

(vi) "tributo" como norma, fato e relação jurídica.

As acepções de tributo trazidas por Paulo de Barros Carvalho decorrem do enfoque que se dá à relação jurídico-tributária. Na primeira, por exemplo, a atenção é voltada ao objeto da prestação (crédito tributário), sendo o tributo conceituado como o objeto da prestação que satisfaz o dever da obrigação tributária ${ }^{14}$. Aqui há a sinonímia entre o conceito de tributo e o de crédito tributário aqui adotado.

Já a última acepção (tributo como norma, fato e relação jurídica), é aquela que parece melhor exprimir o conceito de tributo, pois, como assevera Paulo de Barros Carvalho ${ }^{15}$, é "nesse derradeiro sentido, que exprimi toda a fenomenologia da incidência, desde a norma instituidora, passando pelo evento concreto, nela descrito, até o liame obrigacional que surde à luz com a ocorrência daquele fato". É essa a acepção de tributo que será adotada neste estudo.

Esta acepção é também a que mais se amolda à definição de tributo do artigo $3^{\circ}$ do Código Tributário Nacional ${ }^{16}$, que assim está redigido: “Tributo é toda prestação pecuniária compulsória, em moeda ou cujo valor nela se possa exprimir, que não constitua sanção de ato ilícito, instituída em lei e cobrada mediante atividade administrativa plenamente vinculada."

Ademais, é possível mesclar o conceito de tributo acima trabalhado com a sua definição legal, resultando numa relação jurídico-tributária que decorre de lei e prescinde de vontade das partes (compulsória e instituída em lei), tendo como objeto a entrega de uma quantia em dinheiro (pecuniária, em moeda ou cujo valor nela se possa exprimir), que

\footnotetext{
${ }^{14}$ BECKER, Alfredo Augusto, Teoria Geral do Direito Tributário, 5. ed. São Paulo: Noeses, 2010. p. 280.

${ }^{15}$ CARVALHO , Paulo de Barros. Curso de direito tributário. 22. ed. São Paulo: Saraiva, 2010. p.56/55.

${ }^{16}$ Nesse sentido é a opinião de Paulo de Barros Carvalho: "É com esse com esse conteúdo que o art. $3^{\circ}$. Da Lei n. 5.172/66 se propõe a determiná-lo”. (Ibidem).
} 
será exigida pela Fazenda Pública por meio de atividade administrativa plenamente vinculada, ou seja, sem margem de discricionariedade por parte do agente público ${ }^{17}$.

O conceito de tributo previsto no artigo $3^{\circ}$ do Código Tributário Nacional é complementado pelo artigo $9^{\circ}$ da Lei 4.320/1964, que dispõe ser tributo toda receita derivada, instituída pelas entidades de direito público, nos termos da constituição e das leis vigentes, destinando-se seu produto da arrecadação ao custeio das atividades gerais e específicas $^{18}$.

Sobre a condição de tributo como receita derivada auferida pelo Estado, é precisa a lição de Sacha Calmon Navarro Coelho ${ }^{19}$ :

Se o Estado, tirante sua condição de contratante ou donatário, não está nem arrecadando bens pecuniários vacantes, nem recebendo multas, nem sendo indenizado em tempo de guerra ou paz, nem percebendo pecúnia excontratu, tudo o mais que entra como receita, excluídas as 'entradas de caixa', tais como cauções e fianças, ou é tributo, ou é enriquecimento sem causa. A questão é de ontologia jurídica e não de técnica legislativa.

Em linhas gerais, ainda que não se considere ser atribuição do legislador estabelecer conceitos em Direito, tem-se que a definição de tributo do artigo $3^{\circ}$ do Código Tributário Nacional se ajusta de forma satisfatória às proposições doutrinárias sobre o respectivo conceito, podendo-se, assim, considerar "tributo" como toda a exigência que se subsumir ao conceito estabelecido pelo artigo $3^{\circ}$ do Código Tributário Nacional, com a complementação do artigo $9^{\circ}$ da Lei n. $4.320 / 64^{20}$.

\footnotetext{
${ }^{17}$ Apenas uma ressalva: a previsão "cujo valor nela se possa exprimir", se refere à possibilidade de o tributo ser cobrado por meio de selos e estampilhas. Não trata o dispositivo sobre a forma pela qual poderá ser extinto o crédito tributário. Tal consideração será explorada adiante, razão pela qual remetemos o leitor ao tópico referente à extinção do crédito tributário.

${ }^{18}$ Cf. SCHOUERI, Luís Eduardo. Direito tributário. São Paulo: Saraiva, 2011. p. 131.

${ }^{19}$ Curso de direito tributário. 11. ed. Rio de Janeiro: Forense, 2010. p. 361.

${ }^{20}$ Geraldo Ataliba, apesar de ter alterado o seu pensamento, como se verá adiante, tecia duras críticas à definição legal de tributo, defendendo não ser função de lei nenhuma formular conceitos teóricos, e que o conceito de tributo é constitucional, não podendo a lei alargá-lo, reduzi-lo ou modificá-1o ${ }^{20}$. Ademais, sustentava o referido professor que o conceito de tributo é o conceito-chave para a demarcação das competências legislativas e balizador do regime tributário, conjunto de princípios e regras constitucionais de proteção do contribuinte em face do chamado "poder tributário", motivo pelo qual deveria ser vista com cautela a definição legal. Não obstante isso, reconhece Geraldo Ataliba o mérito do conceito legal quanto à impossibilidade de se inserir no conceito de tributo as multas impostas como sanção pela prática de ato ilícito (cf. ATALIBA, Geraldo. Hipótese de incidência tributária. 6. ed. 5. tir. São Paulo: Malheiros, 2004. p.31-36). Acompanhando a linha de raciocínio de Ataliba, assevera Leandro Paulsen que a Constituição permite que se extraia do seu próprio texto o conceito de tributo por ela considerado ao estabelecer as competências tributárias, as limitações ao poder de tributar e a repartição de receitas tributárias (PAULSEN, Leandro. Curso de direito tributário. Porto Alegre: Livraria do Advogado, 2008. p.25). Não é esta a posição adotada. Isso porque, além de a Constituição Federal não estabelecer o que é tributo, ela expressamente atribui essa função ao legislador complementar, conforme dispõe o artigo 146, inciso III, alínea $a$. Por isso, parece assistir razão a Luís Eduardo Schoueri quando pondera que "A existência de uma noção constitucional de tributo não afasta a importância da definição pela lei
} 
Até aqui, viu-se o crédito tributário é o objeto que materializa o tributo, considerado este como a relação jurídica tributária que impõe ao contribuinte, ou ao responsável tributário, o dever de recolher dinheiro aos cofres públicos.

Definido o crédito tributário, passa-se a perscrutar os meios pelo qual ele pode ser extinto.

\section{2 A extinção do crédito tributário}

Do mesmo modo que as demais obrigações jurídicas, a obrigação de natureza tributária se extinguirá quando não mais estiver presente um ou mais de seus elementos constitutivos. Isso porque, como dito alhures, ou a relação obrigacional está composta de todos os seus elementos ou não há que se falar em obrigação tributária.

As modalidades de extinção das obrigações de natureza tributária obedecem ao princípio da legalidade por expressa determinação do artigo 97, inciso VI, do Código Tributário Nacional, que prevê que somente a lei em sentido estrito poderá estabelecer "as hipóteses de exclusão, suspensão e extinção de créditos tributários, ou de dispensa ou redução de penalidades". Logo, não há hipótese de extinção do crédito tributário que não esteja contida em uma lei, tomado o termo "lei" em seu sentido estrito.

Nesse sentido leciona Paulo de Barros Carvalho ${ }^{21}$ :

Tanto o surgimento quanto as modificações por que passam durante sua existência, e assim também a extinção das obrigações tributárias hão de ocorrer nos precisos termos da lei. Nesse terreno, o princípio da estrita legalidade impera em toda a extensão e a ele se ajunta, em vários momentos, o postulado da indisponibilidade dos bens públicos. ${ }^{22}$

complementar (SCHOUERI, Luis Eduardo. Direito tributário. São Paulo: Saraiva, 2011. p. 131). Ademais, o próprio Geraldo Ataliba alterou seu entendimento, assim comentando o artigo $3^{\circ}$ do CTN: "Já fui dos que criticaram o Código, por conter noções doutrinárias, mas hoje me rendo inteiramente à argumentação do Prof. Rubens, há alguns anos atrás, num curso, aliás, a meu convite, aqui na Universidade Católica, quando ele muito bem demonstrou para a correta aplicação do Código, a necessidade, em primeiro lugar, de termos de referência dos seus mandamentos, e em segundo lugar, a inequívoca utilidade prática de tais termos. Disse então uma frase de grande alcance, que foi decisiva no convencimento de todo o auditório 'se isto hoje não é mais necessário, eu me felicito com o Brasil; se continuar sendo necessário, não há razão para retirar'. Isto, para mim, é razão suficiente para acolher definitivamente não só esta definição como todas as outras que se contêm no Código." (SOUSA, Rubens Gomes de; ATALIBA, Geraldo; CARVALHO, Paulo de Barros. Comentários ao código tributário nacional: parte geral. 2. ed. São Paulo: Quartier Latin, 2007. p. 44-45).

${ }^{21}$ CARVALHO, Paulo de Barros. Curso de direito tributário. 22. ed. São Paulo: Saraiva, 2010. p. 521.

${ }^{22} \mathrm{O}$ postulado indicado pelo citado jurista é um dos fundamentos da execução contra a fazenda pública, e da própria sistemática dos precatórios, motivo pelo qual será analisado adiante. 
A disciplina legal das formas de extinção do crédito tributário é encontrada no artigo 156 do Código Tributário Nacional, que traz em seus onze incisos doze modalidades de extinção do crédito tributário ${ }^{23}$, sendo elas o pagamento (inciso I), a compensação (inciso II), a transação (inciso III) ${ }^{24}$, a remissão (inciso IV) ${ }^{25}$, a prescrição e a decadência (inciso $\mathrm{V})^{26}$, a conversão do depósito em renda (inciso VI), o pagamento antecipado e a homologação do lançamento nos termos do disposto no art. 150 e seus $\S \S 1^{\circ}$ e $4^{\circ}$ (inciso VII), a consignação em pagamento, nos termos do disposto no $\S 2^{\circ}$ do art. 164 (inciso VIII); a decisão administrativa irreformável, assim entendida a definitiva na órbita administrativa, que não mais possa ser objeto de ação anulatória (inciso IX), a decisão judicial passada em julgado (inciso $X$ ) e a dação de bens imóveis, na forma e nas condições estabelecidas em lei (inciso XI) ${ }^{27}$.

${ }^{23}$ O Código Tributário Nacional traz a previsão "extinguem o crédito tributário", quando o mais apropriado seria utilizar a expressão extinguem a "obrigação tributária", uma vez que o crédito tributário é elemento constitutivo da relação jurídico-tributária. Contudo, é inequívoco que extinto o crédito tributário, extinta estará a obrigação tributária.

${ }^{24}$ A Transação é a forma de extinção da obrigação que pressupõe concessões mútuas dos sujeitos nela envolvidos. Como bem observa Luís Eduardo Schoueri "a essência da transação é um litígio (presente ou iminente), que se encerra a partir de concessões das partes", concluindo que "na transação não há ganhador ou perdedor. Há um acordo, que se deu por concessões mútuas." (SCHOUERI, Luís Eduardo. Direito Tributário. São Paulo: Saraiva, 2011. p.564.). A transação não implica a extinção do crédito tributário pelo pagamento, já que a obrigação é extinta pela transação. Daí porque se mostra inviável pretender a repetição do indébito nas hipóteses de transação, pois o pagamento que surge com ela não está relacionado à obrigação original, tendo como causa a própria transação.

${ }^{25}$ A remissão nada mais é que o perdão da dívida pelo credor, nos termos da lei, com consequente extinção da obrigação. A palavra remissão decorre do verbo remitir, que tem significado de perdão, diferente do verbo remir, que dá origem à remição, que significa resgate. Por fim, não há que se confundir a remissão, que é o perdão do crédito tributário, modalidade de extinção da obrigação tributária, com a anistia, prevista nos artigos 175, inciso II, e 180 a 182 do Código Tributário Nacional, uma vez que essa trata de hipótese de perdão de uma infração à legislação tributária (ato ilícito ou penalidade pecuniária), cuidada pelo CTN como forma de exclusão do crédito tributário.

${ }^{26}$ A decadência e a prescrição são modalidades de extinção da relação obrigacional tributária relacionadas à segurança jurídica, fundadas na ideia de que a inércia no exercício de um direito, pelo prazo legalmente assinalado, conduz ao seu perecimento (Cf. COSTA, Regina Helena. Curso de direito tributário: constituição e código tributário nacional. São Paulo: Saraiva, 2009. p. 267). O regramento dessas modalidades de extinção da obrigação tributária é reservado à lei complementar por expressa determinação do artigo 146, inciso III da Constituição da República. A decadência e a prescrição estão disciplinadas, respectivamente, pelos artigos 173 e 174 do Código Tributário Nacional. Em suma, a decadência é a perda do direito de a Fazenda Pública constituir o crédito tributário. Já a prescrição é a perda do direito de ajuizamento de ação para a cobrança do crédito tributário.

${ }^{27}$ Hugo de Brito Machado ressalta que o rol do artigo 156 do CTN não é exaustivo, apontando o jurista que, embora seja excepcional, outras poderão ser as hipóteses de extinção do crédito tributário, como a confusão, citando como exemplo um bem que passa à titularidade do Poder Público em decorrência de herança jacente. Nesse caso, em relação ao ente federado que se tornou proprietário do bem, serão extintos os créditos tributários a ele vinculados (Comentários ao código tributário nacional. v. III. São Paulo: Atlas, 2005. p. 302). Mesmo posicionamento tem Regina Helena Costa: "O rol de modalidades extintivas é longo, mas não exaustivo. Pode-se, ainda, cogitar de outras modalidades de extinção das obrigações em geral, segundo a disciplina do Código Civil, como a hipótese de confusão." (COSTA, Regina Helena. Curso de direito tributário: constituição e código tributário nacional. São Paulo: Saraiva, 2009. p. 246). 
Neste capítulo serão analisados o pagamento e a compensação, na medida em que essas são as únicas modalidades de extinção do crédito tributário que se relacionam ao estudo ora proposto, uma vez que são nessas hipóteses que o contribuinte pode tentar se valer de precatórios para se libertar do liame obrigacional.

\subsubsection{O pagamento (e seus desdobramentos)}

O pagamento é a forma ordinária de extinção de uma relação obrigacional, por meio da qual o devedor entrega ao credor o objeto da prestação.

A palavra "pagamento" apresenta mais de um sentido, exigindo seja ela delimitada para a compreensão de sua utilização neste estudo.

Pagamento pode ser considerado em seu sentido amplo, conceito tradicionalmente utilizado pelos civilistas, oriundo da "Teoria das Obrigações", o qual englobaria qualquer modalidade de adimplemento da obrigação, abarcando, inclusive, todas as causas de extinção do crédito tributário previstas no artigo 156 do Código Tributário Nacional.

Leciona Maria Helena Diniz ${ }^{28}$ que pagamento em sentido lato é aquele que designa a execução satisfatória da obrigação, ou seja, solução, adimplemento, resolução, implemento, cumprimento, assim concluindo:

\footnotetext{
[...] percebe-se daí que o vocábulo em tela [pagamento] abrange quaisquer meios extintivos da relação obrigacional, correspondendo à solutio do direito romano, pela qual se dissolvia o vinculum iuris da obrigação, incluindo não só a efetivação exata da prestação daquilo que forma o objeto da obrigação, como também a novação, a compensação, a confusão, a transação, a remissão de dívida etc.
}

Há também o sentido estrito do termo pagamento, o qual representa o ato do sujeito passivo de entregar certa quantia de dinheiro ao sujeito ativo da relação obrigacional. Em seu sentido estrito, corresponde o pagamento à efetiva entrega pelo devedor daquilo que exatamente lhe é exigido, exaurindo qualquer pretensão por parte do credor. Em sentido estrito, pagamento é espécie do gênero solução da obrigação.

Nessa esteira é a lição de Silvio de Salvo Venosa ${ }^{29}$ :

${ }^{28}$ DINIZ, Maria Helena. Curso de direito civil brasileiro: teoria geral das obrigações. v. 2. São Paulo: Saraiva, 2011. p. 238. 
Contudo, o termo pagamento, no sentido estritamente técnico e tal como está nos arts. 304 ss do Código [Código Civil], é toda forma de cumprimento da obrigação. Trata-se das solutio, solução do velho direito. A obrigação, a dívida, solve-se, resolve-se, paga-se. Tendemos a ver o termo solução da obrigação como o gênero, do qual o pagamento (em dinheiro, portanto), seria a espécie.

E é nesse sentido (estrito) que o artigo 156, inciso I do Código Tributário Nacional utiliza o termo "pagamento", uma vez que a relação tributária, à luz do artigo $3^{\circ}$ do CTN, é estritamente pecuniária.

O artigo 162, inciso I do Código Tributário Nacional determina que o pagamento do tributo seja efetuado em moeda corrente, cheque ou vale postal, ressalvando o inciso II do mesmo artigo, que nos casos previstos em lei, poderá ser o pagamento efetuado em estampilha, papel selado, ou por processo mecânico.

Luís Eduardo Schoueri ${ }^{30}$ assim explica a opção do legislador:

Mas se é 'em moeda', porque a expressão 'ou cujo valor nela se possa exprimir'? Esse cuidado do legislador se deve ao fato de que, por vezes, o tributo não é pago, diretamente, em moeda: o contribuinte compra, com moeda, um selo ou estampilha e o tributo é pago com a utilização da última. Assim, por exemplo, o selo que se põe nas embalagens de cigarros e bebidas. Ou seja: o pagamento do tributo dá-se com o uso da estampilha, mas esta, por óbvio, tem o valor expresso em moeda.

Nessa linha também se posiciona Sacha Calmon Navarro Coêlho ${ }^{31}$ :

Obviamente pode o credor, no caso o Estado, se quiser e autorizado pela lei, aceitar em dação em pagamento um bem que não dinheiro. Incidem em erronia os que enxergam na cláusula valor que nela se possa exprimir uma licença para pagar tributos com vacas, coelhos ou hortaliças. É que se pode pagar com selos ou estampilhas. A obrigação tributária é de dar coisa certa.

Assim, quando a legislação tributária se refere ao "pagamento" como meio de extinção da obrigação tributária, deve ele ser entendido como a quantia certa em dinheiro, instrumentalizada em moeda corrente, que será entregue aos cofres públicos.

Com o avanço do sistema financeiro, hoje é cada vez mais comum que o pagamento dos tributos seja realizado online, por meio da rede mundial de computadores. Esse pagamento também é considerado como realizado em dinheiro (pecúnia), pois há a transferência do numerário (em moeda corrente), correspondente ao total devido, a débito de uma conta bancária de titularidade do sujeito passivo com o respectivo crédito em conta

\footnotetext{
${ }^{29}$ VENOSA, Sílvio de Salvo. Direito civil: teoria geral das obrigações e teoria geral dos contratos. 12. ed. São Paulo: Atlas, 2012. p 172.

${ }^{30}$ SCHOUERI, Luís Eduardo. Direito Tributário. São Paulo: Saraiva, 2011. p. 133.

${ }^{31}$ COÊLHO; Sacha Calmon Navarro. Curso de direito tributário. 11. ed. Rio de Janeiro: Forense, 2010. p 660.
} 
bancária de titularidade do sujeito ativo da relação obrigacional, extinguindo a relação jurídico-tributária com a confirmação da transação financeira.

Ainda em relação ao pagamento, determina o artigo 164 do Código Tributário Nacional que nos casos de recusa de recebimento do pagamento, ou subordinação deste ao pagamento de outro tributo ou de penalidade, ou ao cumprimento de obrigação acessória, de subordinação do recebimento ao cumprimento de exigências administrativas sem fundamento legal, e de exigência por mais de uma pessoa jurídica de direito público de tributo idêntico sobre um mesmo fato gerador, que poderá o sujeito passivo "consignar em juízo" o valor integral do crédito tributário, extinguindo a obrigação tributária.

Note-se que as hipóteses de cabimento da ação de consignação em pagamento são taxativas, sendo defeso o ajuizamento desta ação sem a comprovação de prévio depósito do montante integral, em dinheiro, correspondente ao crédito tributário que se pretende pagar $^{32}$. Ademais, não se admite o ajuizamento da ação de consignação em pagamento com o oferecimento de coisa diversa de dinheiro, vez que o termo "valor" utilizado pelo artigo 164 do CTN significa exclusivamente dinheiro.

Tanto é assim que julgada procedente a consignação o pagamento se reputa efetuado (artigo 156, inciso VIII do CTN) e a importância consignada é convertida em renda. No entanto, julgada improcedente a consignação no todo ou em parte, cobra-se o crédito acrescido de juros de mora, sem prejuízo das penalidades cabíveis (artigo 164, $\S 2^{\circ}$ do CTN).

Esse raciocínio também se aplica à hipótese de extinção do crédito tributário pela conversão do depósito em renda (artigo 156, inciso VI do CTN). Isso porque o depósito realizado com a finalidade de suspender a exigibilidade do crédito tributário, nos termos do artigo 151, inciso II do CTN, deve ser efetuado necessariamente em dinheiro, correspondendo a quantia depositada ao montante total devido ${ }^{33}$.

Assim, há pagamento tanto na consignação em pagamento, como na conversão do depósito em renda, pois nas duas situações o sujeito passivo da relação jurídico-tributária entrega ao credor a quantia em dinheiro correspondente ao crédito tributário devido.

\footnotetext{
${ }^{32}$ Nesse sentido, o Superior Tribunal de Justiça já consolidou o entendimento de que "a ação de consignação em pagamento não é o instrumento processual adequado para a obtenção de parcelamento fiscal"(REsp 1095240/RS, Rel. Ministra Eliana Calmon, Segunda Turma, julgado em 09/12/2008, DJe 27/02/2009,AgRg no REsp 969.554/RS, Rel. Ministro Francisco Falcão, Primeira Turma, julgado em 02/10/2007, DJ 12/11/2007, p. 195).

${ }^{33}$ Nesse sentido é a súmula $\mathrm{n}^{\circ} 112$ do Superior Tribunal de Justiça: "O depósito somente suspende a exigibilidade do credito tributário se for integral e em dinheiro".
} 
Por fim, constatando-se que o pagamento se deu de modo indevido, nascerá ao sujeito passivo que o realizou o direito à restituição do valor indevidamente despendido, $\mathrm{o}$ que poderá ser pleiteado administrativa ou judicialmente.

Não há uma definição em lei do que seja "indébito tributário". Porém, o direito à repetição do indébito tributário é disciplinado pelo artigo 165 do CTN, o qual determina que, ressalvado as hipóteses de perda ou destruição da estampilha, ou o erro no pagamento por esta modalidade, o sujeito passivo tem direito, independentemente de prévio protesto, à restituição total ou parcial do tributo, seja qual for a modalidade do seu pagamento, nos casos de: (a) cobrança ou pagamento espontâneo de tributo indevido ou maior que o devido nos termos da legislação tributária aplicável, ou da natureza ou circunstâncias materiais do fato gerador efetivamente ocorrido (artigo 165, inciso I); (b) erro na identificação do sujeito passivo, na determinação da alíquota aplicável, no cálculo do montante do débito ou na elaboração ou conferência de qualquer documento relativo ao pagamento (artigo 165, inciso II); e (c) reforma, anulação, revogação ou rescisão de decisão condenatória (artigo 165, inciso III).

No termos do artigo 167 do Código Tributário Nacional, a restituição total ou parcial do tributo será acrescida, na mesma proporção, dos juros de mora e das penalidades pecuniárias, salvo as referentes a infrações de caráter formal não prejudicadas pela causa da restituição.

A restituição do indébito poderá ser requerida dentro do prazo de cinco anos, contados nas hipóteses de pagamento espontâneo indevido, maior que o devido e erroneamente calculado, da data da extinção do crédito tributário (artigo 168, I do CTN), e nos casos de reforma, anulação, revogação ou rescisão de decisão condenatória, da data em que se tornar definitiva a decisão administrativa ou passar em julgado a decisão judicial que tenha reformado, anulado, revogado ou rescindido a decisão condenatória.

Requerida administrativamente a restituição dos valores indevidamente recolhidos, prescreverá, nos termos do artigo 169 do CTN, em dois anos o prazo para o ajuizamento de ação anulatória da decisão administrativa que denegar o pedido de restituição, interrompendo-se tal prazo pelo início da ação judicial, recomeçando o seu curso, pela metade, a partir da data da intimação validamente feita ao representante judicial da Fazenda Pública interessada (artigo 169, parágrafo único, do CTN). 
Até aqui, pode-se concluir que o termo "pagamento" para fins tributários é aquele realizado em dinheiro (moeda corrente), permitindo-se a sua restituição nas hipóteses em que for reconhecido como indevido.

Entretanto, o fato de a obrigação tributária exigir que a prestação seja adimplida com a entrega de dinheiro (moeda corrente) aos cofres públicos não impede, caso haja interesse do ente tributante, e nos termos de lei específica, que o pagamento seja efetuado pela entrega de coisa diversa de dinheiro.

É a hipótese, por exemplo, do artigo 156, inciso XI do Código Tributário Nacional $^{34}$ que permite, como meio extintivo da obrigação tributária, "a dação em pagamento em bens imóveis, na forma e condições estabelecidas em lei”.

Contudo, em situações como a do citado dispositivo legal, em que o termo "pagamento" estiver relacionado a uma entrega de coisa que não seja moeda, este somente poderá ser entendido em seu sentido amplo (lato), de modo geral de satisfação da obrigação. Do que se conclui que na "dação em pagamento", o crédito tributário será extinto pela "dação de bem imóvel”, que é uma das espécies do gênero "extinção de obrigações" (artigos 356 a 359 do Código Civil), e não pelo "pagamento" no sentido em que o termo é utilizado pelo artigo 156, inciso I do CTN.

Alfredo Augusto Becker sustenta em sua obra que a obrigação tributária apresentaria diversas configurações, agrupando-as em pecuniária, in natura e in labore, sendo que estas últimas, por vontade do ente competente, e também nos termos da lei, poderiam ser adimplidas por outra forma de prestação que não em moeda ${ }^{35}$.

Defende o aludido jurista que "o objeto da prestação é que poderá variar segundo critério de política fiscal; esta poderá escolher (mediante criação de regra jurídica) em lugar do dinheiro, um outro bem (ex. imóvel) ou um serviço pessoal." 36

Para Becker, os tributos in natura ou in labore não seriam alternativos aos tributos pecuniários, mas se relacionariam com estes de forma integrativa ${ }^{37}$.

O raciocínio do citado jurista toma como ponto de partida um conceito jurídico de dinheiro diferente do conceito econômico de dinheiro, salientando a importância de se

\footnotetext{
${ }^{34}$ Alteração promovida pelo artigo $1^{\circ}$ da Lei Complementar n ${ }^{\circ}$ 104, de 10 de janeiro de 2001.

${ }^{35}$ BECKER, Alfredo Augusto. Teoria geral do direito tributário. 5. ed. São Paulo: Noeses, 2010. p. 658677.

${ }^{36}$ Ibidem. p. 677.

${ }^{37}$ Ibidem. p. 661.
} 
determinar a função, ou funções essenciais do dinheiro, porque de tal determinação decorrerá a conclusão de que será dinheiro aquele bem que exerça tal ou tais funções ${ }^{38}$.

Becker demonstra que o dinheiro no plano econômico desempenharia as funções (i) de meio geral de escambo, (ii) meio de transporte, no tempo e no espaço, da medida comum (unidade ideal ou abstrata) de valor e (iii) meio geral de pagamento ou mais precisamente: meio geral de satisfação de prestações do dever jurídico ${ }^{39}$.

Já no plano jurídico, o dinheiro poderia ser conceituado como o meio geral de satisfação das prestações de dever jurídico, de modo que o bem escolhido pelo direito pode não ser o bem que, no plano econômico e em determinadas condições de tempo e espaço, esteja desempenhando as funções econômicas do dinheiro. O dever jurídico de prestação em dinheiro é dever de dar determinada quantidade unidade ideal de valor conduzido (ou incorporados) pelo dinheiro ${ }^{40}$.

Seguindo essa linha de raciocínio, estabelece Becker que para a relação jurídica ter natureza tributária pouco importa que a obrigação por ela gerada seja satisfeita por uma prestação em dinheiro, in natura ou in labore, pois, nestas três hipóteses, o conteúdo jurídico da prestação será sempre um prestar, isto é, um ato positivo (facere) ou negativo (non facere) do sujeito passivo da relação jurídica ${ }^{41}$.

Desse modo, tendo em conta as premissas por ele fixadas, Becker entende serem de natureza tributária as relações de desapropriação, requisição administrativa e prestação de serviço militar ${ }^{42}$.

Em que pese o raciocínio muito bem desenvolvido pelo mencionado jurista ${ }^{43}$, pelas razões até aqui delineadas, não há como se sustentar a existência de uma relação jurídica de índole tributária que não seja pecuniária, e muito menos que se tenha sob o império da legislação tributária vigente o termo "pagamento", em seu sentido estrito, representado pelo adimplemento de uma prestação que não seja a entrega de moeda (dinheiro). Ademais

\footnotetext{
${ }^{38}$ Ibidem. p. 671.

${ }^{39}$ Ibidem. p. 671-672.

${ }^{40}$ Ibidem. p. 675.

${ }^{41}$ Ibidem. p. 677-678.

${ }^{42}$ BECKER, Alfredo Augusto. Teoria geral do direito tributário. 5. ed. São Paulo: Noeses, 2010. p. 677680.

${ }^{43}$ Paulo de Barros Carvalho, levando em consideração as características da obrigação tributária e do próprio conceito de tributo, tece o seguinte comentário à teoria exposta: "Não compreendemos, assim, que A. A. Becker possa vir a abrangê-los numa só figura, sem sacrifício da própria precisão terminológica que se entende essencial ao estudo de qualquer ciência". (Teoria da norma tributária. 4. ed. São Paulo: Max Limonad, 2002. p. 104).
} 
não é possível aproximar o conceito de moeda (dinheiro) ao de modo geral de satisfação das prestações de dever jurídico.

Isso porque "moeda" é um termo juridicamente definido, de modo que será moeda apenas o que uma norma jurídica disser que é.

Nesse sentido ensina Roberto Quiroga Mosquera ${ }^{44}$ :

O Direito dirá o que é moeda, logo, nesse sentido, moeda é norma, é estrutura de linguagem, linguagem prescritiva. Sem dúvida esta é a marca mais forte do conceito de moeda. Nas economias modernas e no Direito contemporâneo, a moeda tem estatura legal. Só é moeda aquilo que o Direito disser que é.

O conceito jurídico de "moeda" atualmente é determinado pelo artigo $1^{\circ}$ da Lei 9.069 de 29 de junho de 1995, que assim está redigido: “A partir de $1^{\text {o }}$ de julho de 1994, a unidade do Sistema Monetário Nacional ${ }^{45}$ passa a ser o REAL, que terá curso legal em todo o território nacional".

Logo, somente haverá obrigação de natureza tributária se esta for pecuniária (artigo $3^{0}$ do $\mathrm{CTN}$ ), bem como a extinção do liame obrigacional por meio do pagamento, nos estritos termos do artigo 156, inciso I do Código Tributário Nacional, ocorrerá apenas se este for realizado em REAL, ou seja, pelo ato de entrega de dinheiro pelo sujeito passivo da relação jurídico-tributária aos cofres públicos.

\subsubsection{A compensação tributária e a repetição do indébito tributário}

A compensação é a modalidade de extinção do liame obrigacional que pressupõe a existência de duas relações jurídicas, em que o credor de uma é o devedor de outra e vice$\operatorname{versa}^{46}$.

O termo compensação derivaria das expressões latinas cum pensare e cum pendere, que significariam pesar junto ou ao mesmo tempo, nos pratos de uma balança, até que se

\footnotetext{
${ }_{44}^{44}$ Direito monetário e tributação da moeda. São Paulo: Dialética, 2006. p. 58.

45 Roberto Quiroga Mosquera explica que “a locução 'sistema monetário' contemplaria uma noção mais adequada para o termo moeda, uma vez que explicita ser a moeda o instrumento universal de troca na sociedade e define qual a unidade monetária com que se deve valorar as mercadorias e serviços; no caso do Brasil, o real, isto é, uma unidade monetária de real, duas unidades monetárias de real etc." (Direito monetário e tributação da moeda. São Paulo: Dialética, 2006. p. 51).

${ }^{46}$ Cf. CARVALHO, Paulo de Barros. Curso de direito tributário. 22. ed. São Paulo: Saraiva, 2010. p. 530.
} 
alcançasse o equilíbrio, que representaria a igualdade de créditos, permitindo-se a extinção de duas obrigações em que credores e devedores ocupam lugares opostos.

Com efeito, nesse período os metais eram a medida comum de valor (moeda) e, assim, necessitavam serem pesados e precisados para que fosse possível se aferir o seu valor, já que os metais não traziam consigo o seu valor.

São esses os ensinamentos de Maria Helena Diniz ${ }^{47}$ :

O termo compensação deriva etimologicamente do substantivo latino compensatio, onis, significando compensação, balança, remuneração, que se origina do verbo latino compensare, ou seja, compensar, remunerar, colocar em balança, contrabalançar, que, por sua vez, advém de compendere, isto é, pesar com, pesar juntamente. Os dois verbos apresentam como prefixo a preposição com (cum pensare e cum pendere no sentido de pesar com ou de pesar ao mesmo tempo nos pratos de uma balança). Isto porque, para medida comum de valor, os romanos se utilizavam de metais que precisavam ser pesados, pois naquela época não traziam o seu valor marcado por qualquer sinal.

Determina o artigo 368 do Código Civil que "se duas pessoas forem ao mesmo tempo credor e devedor uma da outra, as duas obrigações extinguem-se, até onde se compensarem". Complementa esse dispositivo o artigo 369 do mesmo diploma legal, que estabelece que "a compensação efetua-se entre dívidas líquidas, vencidas e de coisas fungíveis".

Destarte, os requisitos para a compensação das obrigações em geral são: reciprocidade de obrigações, liquidez de dívidas, exigibilidade das prestações e fungibilidade das coisas devidas ${ }^{48}$.

Tais requisitos, em se tratando de obrigações tributárias, são ajustados ao regramento específico dos artigos 170 e 170- A do Código Tributário Nacional.

O artigo 170 do Código Tributário Nacional estabelece que somente por meio de lei, em sentido estrito, emanada dos entes políticos competentes, pode-se, nas condições e sob as garantias que ela estipular, ou cuja estipulação em cada caso atribuir à autoridade administrativa, autorizar a compensação de créditos tributários com créditos líquidos e certos, vencidos ou vincendos, do sujeito passivo contra a Fazenda Pública ${ }^{49}$.

${ }^{47}$ DINIZ, Maria Helena. Curso de direito civil brasileiro: teoria geral das obrigações. v. 2. São Paulo: Saraiva, 2011, p. 309/310.

${ }^{48}$ Cf. CARVALHO, op. cit. p. 530-531.

${ }^{49} \mathrm{O}$ parágrafo único do citado artigo esclarece que sendo vincendo o crédito do sujeito passivo, a lei determinará a apuração do seu montante, não podendo, porém, cominar redução maior que a correspondente ao juro de $1 \%$ (um por cento) ao mês pelo tempo a decorrer entre a data da compensação e a do vencimento. 
Verifica-se aqui a primeira particularidade da compensação tributária, pois esta não é limitada aos créditos vencidos, sendo admitida a sua realização com créditos vincendos, desde que observado no cálculo do crédito o mínimo de juro fixado pelo parágrafo único do artigo 170 do Código Tributário Nacional.

Outra especificidade da compensação tributária, desta vez mais marcante, é a de não haver nela margem para a discricionariedade da Administração Tributária, pois a compensação deverá ser realizada de acordo com a previsão legislativa que a regulamente. A observância à lei é estrita.

Paulo de Barros Carvalho assevera que a lei que autoriza a compensação pode estipular condições e garantias, ou instituir os limites para que a autoridade administrativa assim o faça, mas num ou noutro caso a atividade será vinculada ${ }^{50}$.

Esse também é o caminho trilhado por Marcelo Fortes de Cerqueira ${ }^{51}$, para quem “não consiste o direito à compensação numa exigência impostergável do Sistema Constitucional Tributário. Logo, em sendo a sua previsão uma prerrogativa do legislador ordinário, aceitará vedações, restrições e condicionamentos criados por este, desde que mediante lei.",52

A lei autorizadora da compensação poderá ser editada pelos mesmos entes políticos detentores de competência tributária, de modo que haverá regulamentação específica para a compensação nas três esferas da Federação: União, Estados-membros e Municípios, além do Distrito Federal, que detém as competências tributárias estaduais e municipais.

Demais disso, o artigo 170-A do Código Tributário Nacional condiciona a compensação decorrente de sentença que reconheça a ilegitimidade da cobrança do crédito tributário (indébito tributário) ao trânsito em julgado da respectiva decisão judicial.

Sobre o teor da decisão judicial alerta Leandro Paulsen que: "Não é imprescindível que o dispositivo mencione o direito à compensação, porém deverá ser inequívoco o

${ }^{50}$ Cf. CARVAlHO, Paulo de Barros. Curso de direito tributário. 22. ed. São Paulo: Saraiva, 2010. p. 531.

${ }^{51}$ CERQUEIRA, Marcelo Fortes de. Extinção da obrigação tributária: compensação e repetição do indébito. In: Curso de especialização em direito tributário: estudos analíticos em homenagem a Paulo de Barros Carvalho. Rio de Janeiro: Forense, 2005. p. 401.

${ }^{52}$ Alinha-se a esse pensamento Eudimar Alves Ferreira, ao ponderar que: "Não é demais afirmar que o art. 170 do CTN, como regra geral de Direito Tributário, é dirigido ao legislador de todos os entes políticos, sendo insuficiente, de per si, para conferir ao sujeito passivo da obrigação tributária o direito à compensação. Inexistindo lei autorizadora específica e, também, regra regulamentar, que prevejam as condições e as garantias em que a compensação deva se realizar, inexiste direito subjetivo do sujeito passivo à compensação. Daí concluir-se que a compensação que tem por objeto créditos proveniente de exigências de natureza fiscal não se opera automaticamente, nem tampouco é obrigatória, como ocorre no Direito Privado". (Um estudo sobre a compensação tributária. In: SCAFF, Fernando Facury (coord.). Direito tributário e financeiro aplicado. São Paulo: Quartier Latin, 2010. p.235). 
reconhecimento do indébito, com a declaração de inexistência da obrigação tributária na hipótese". 53

Cabe lembrar que antes da vigência do artigo 170-A do CTN diversos foram os questionamentos judiciais por parte dos contribuintes em torno da compensação pleiteada em juízo, o que possibilitou fossem proferidas decisões outorgando o direito à compensação, com a consequente extinção do crédito tributário, antes do trânsito em julgado da decisão que reconhecesse a inexigibilidade do tributo. Por vezes tal pedido era deferido até mesmo em decisões liminares ${ }^{54}$.

Assim, com a alteração legislativa acima (artigo 170-A do CTN), não há mais dúvida de que a compensação lastreada em decisão que reconheça o tributo como indevido, somente poderá ser autorizada com o trânsito em julgado daquela decisão, ou seja, quando a decisão não puder mais ser reformada ${ }^{55}$.

O artigo 170-A do CTN, além de determinar o termo inicial para a compensação reconhecida judicialmente, reafirma importante peculiaridade da compensação tributária, qual seja, a de que a compensação sempre esteve relacionada à repetição do indébito tributário.

Com efeito, para a efetivação de uma compensação tributária exige-se que o encontro de contas tenha como suporte duas relações jurídicas onde haja perfeita identidade de elementos, permitindo-se que se proceda apenas à inversão dos sujeitos em cada polo.

Essa identidade entre sujeitos da relação obrigacional - devedor e credor, em Direito Tributário, somente se verifica de forma perfeita quando se está diante de um indébito tributário.

Portanto, a compensação tributária é caracterizada pelo confronto de uma relação jurídica que apresenta o Fisco como credor tributário com outra, também de natureza

${ }^{53}$ PAULSEN, Leandro. Curso de Direito Tributário. Porto Alegre: Livraria do Advogado, 2008. p.192.

${ }^{54}$ Essa situação ensejou a edição da Súmula $n^{\circ} 212$ do Superior Tribunal de Justiça com o seguinte verbete: “A compensação de créditos tributários não pode ser deferida em ação cautelar ou por medida liminar cautelar ou antecipatória". Ressalte-se que essa redação foi deliberada em 11/05/2005, substituindo a redação de 23/09/1998, que determinava que "a compensação de créditos tributários não pode ser deferida por medida liminar."

55 A Primeira Seção do Superior Tribunal de Justiça, no julgamento dos recursos especiais 1.164.452/MG e 1.167.039/DF (DJe 01/09/2010), submetidos ao regime do artigo 543-C do Código de Processo Civil (recursos repetitivos), reafirmou o entendimento consolidado pela própria Primeira Seção de que, em se tratando de compensação de crédito objeto de controvérsia judicial, não se aplica às demandas ajuizadas anteriormente à vigência da LC104/2001, de 10.1.2001, o disposto no artigo 170-A do Código Tributário Nacional. 
tributária, na qual este mesmo ente tributante se afigure como devedor de um indébito tributário.

É o que leciona Marcelo Fortes de Cerqueira ${ }^{56}$ : "A própria compensação é, num dado sentido, uma forma de se proceder à repetição do indébito, ou melhor, é a causa de extinção tanto da obrigação tributária quanto da relação jurídica de repetição.”

É ainda o entendimento de Diva Malerbi ${ }^{57}$ :

como norma geral, a Lei 5.172/66 não cria por si direito subjetivo à compensação tributária. Este é o fruto exclusivo da lei, da pessoa política competente, que conterá a previsão das condições e garantias sob as quais as dívidas recíprocas serão compensadas. São, assim, requisitos da compensação tributária: a) a existência de crédito do Fisco; b) a existência de débito do Fisco; c) ato, quer do Fisco, quer do particular, que realize esse encontro de relações jurídicas; e d) lei, da pessoa política competente, que autorize.

Logo, reconhecido no âmbito administrativo, ou por decisão judicial, o direito do sujeito passivo à restituição do indébito tributário, dada a ilegitimidade de sua cobrança, poderá o sujeito passivo pleitear a restituição desse valor por meio precatório, ou optar pela compensação, nos termos da legislação que a regulamenta.

Nessa linha é o entendimento sumulado pelo Superior Tribunal de Justiça de que “O contribuinte pode optar por receber, por meio de precatório ou por compensação, o indébito tributário certificado por sentença declaratória transitada em julgado" ${ }^{, 58}$.

No entanto, é sabido que o contribuinte que optar pelo pedido de restituição poderá aguardar por um longo período até o efetivo recebimento dos valores indevidamente recolhidos.

Por essa razão, surge a compensação tributária como alternativa vantajosa ao sujeito passivo, que poderá não se submeter à morosa espera dessa restituição, pleiteando a extinção de sua dívida tributária até o limite dos valores que foram reconhecidos como indevidamente recolhidos, por meio de um procedimento compensatório, que não raro, é muito mais rápido do que a repetição.

Nesse sentido pondera Paulo Cesar Conrado ${ }^{59}$ : "Com isso, temos de conclusivo, afora o que já foi expedido, que a compensação é, sob certa ótica, verdadeiro sucedâneo da

\footnotetext{
${ }^{56}$ CERQUEIRA, Marcelo Fortes de. Extinção da obrigação tributária: compensação e repetição do indébito. In: Curso de especialização em direito tributário: estudos analíticos em homenagem a Paulo de Barros Carvalho, Rio de Janeiro: Forense, 2005. p. 375.

57 MALERBI, Diva Prestes Marcondes. A cláusula pétrea da legalidade tributária e o instituto da compensação. Revista de direito tributário, n 67, São Paulo: Malheiros, 1995. p. 280.

${ }^{58}$ Súmula 461 STJ.

${ }^{59}$ CONRADO, Paulo Cesar. Compensação tributária e processo. 2. ed. São Paulo: Quartier Latin, 2010. p. 101.
} 
execução decorrente da prolatação de sentença condenatória em ação de repetição do indébito."

Contudo, ressalva Conrado ${ }^{60}$ que essa situação:

[...] se dá, marque-se, não porque esse último instituto esteja à beira da falência, ou porque o seu sistema, pela via judicial, padeça do problema do precatório. Tratamento desse jaez importaria a colocação da compensação sob a amesquinhada rubrica de paliativo, de um remédio, imagem que até poderia ser traçada se se estivesse cuidando do tema sob o prisma econômico, ético, etc.; juridicamente, porém, a relação que existe entre a compensação e execução via precatório tem seu ponto de apoio na circunstância de a primeira, tanto quanto a segunda, configurar iniludível mecanismo de desintegração da relação de débito do fisco, pertencente a uma classe onde se supõe, segundo ressaltado, a provocação do contribuinte.

Em suma, defende Conrado, sob o ponto de vista jurídico, não se poder atribuir à compensação tributária a pecha de "simples paliativo" ao demorado procedimento de restituição do indébito tributário, alocando, por esse motivo, o instituto como um importante mecanismo de extinção da obrigação tributária, inserido nas modalidades de extinção que exigem postura ativa do sujeito passivo.

Em que pese tal consideração, dúvida não há de que o viés econômico aludido pelo citado jurista, corolário da rapidez e eficácia do procedimento de compensação, valorizou sobremaneira o instituto, ensejando, inclusive, a edição do artigo 170-A do Código Tributário Nacional, que é voltado especificamente à compensação de tributos com créditos decorrentes de um indébito tributário.

Nesse ponto, pode-se concluir que a compensação em Direito Tributário será realizada sempre em estrita observância à legislação específica, editada pelos entes políticos detentores da competência tributária relativa ao tributo que será extinto por meio da compensação, a qual não é limitada aos créditos tributários vencidos.

Ademais, verificou-se que a compensação tributária está diretamente relacionada ao indébito tributário, em virtude da perfeita identidade dos elementos da relação obrigacional, ressalvando o Código Tributário Nacional que para a compensação de valores cuja ilegitimidade da exigência é pleiteada judicialmente, deve-se aguardar o trânsito em julgado da decisão que assim o reconheça.

Corroborando essas conclusões, nota-se que o legislador ordinário, na esfera federal, sempre restringiu as hipóteses e possibilidades de compensação, limitando-as aos créditos de natureza tributária, decorrentes do pagamento indevido ${ }^{61}$.

${ }^{60}$ Ibidem. loc. cit. 
Em breve síntese de legislação federal, a compensação, no âmbito federal, vinha disciplinada no artigo $7^{\circ}$ do Decreto-Lei n 2.287 de 23 de julho de 1986, que determinava, nas hipóteses de restituição ou ressarcimento de tributos, que "existindo débito em nome do contribuinte, o valor da restituição ou ressarcimento será compensado, total ou parcialmente, com o valor do débito".

Já em 30 de dezembro de 1991, foi editada a Lei $n^{\circ} 8.383^{62}$ que em seu artigo 66 deu novo regramento à compensação tributária, assim dispondo:

Art. 66. Nos casos de pagamento indevido ou a maior de tributos e contribuições federais, inclusive previdenciárias, mesmo quando resultante de reforma, anulação, revogação ou rescisão de decisão condenatória, o contribuinte poderá efetuar a compensação desse valor no recolhimento de importância correspondente a períodos subseqüentes.

$\S 1^{\circ}$ A compensação só poderá ser efetuada entre tributos e contribuições da mesma espécie.

$\S 2^{\circ}$ É facultado ao contribuinte optar pelo pedido de restituição.

$\S 3^{\circ}$ A compensação ou restituição será efetuada pelo valor do imposto ou contribuição corrigido monetariamente com base na variação da Ufir.

$\S 4^{\circ}$ O Departamento da Receita Federal e o Instituto Nacional do Seguro Social (INSS) expedirão as instruções necessárias ao cumprimento do disposto neste artigo.

O artigo 66 da Lei $n^{\circ} 8.383 / 91$ teve sua redação dada pelo artigo 58 da Lei $n^{\circ} 9.069$

de 29 de junho de 1995, passando a dispor que:

Art. 66. Nos casos de pagamento indevido ou a maior de tributos, contribuições federais, inclusive previdenciárias, e receitas patrimoniais, mesmo quando resultante de reforma, anulação, revogação ou rescisão de decisão condenatória, o contribuinte poderá efetuar a compensação desse valor no recolhimento de importância correspondente a período subseqüente.

$\S 1^{\circ}$ A compensação só poderá ser efetuada entre tributos, contribuições e receitas da mesma espécie.

$\S 2^{\circ}$ É facultado ao contribuinte optar pelo pedido de restituição.

$\S 3^{\circ}$ A compensação ou restituição será efetuada pelo valor do tributo ou contribuição ou receita corrigido monetariamente com base na variação da UFIR.

${ }^{61}$ No âmbito federal, a compensação pode ser efetuada a partir de iniciativa do contribuinte, ou pelo Fisco, de ofício. A compensação pelo Fisco no seu próprio interesse é realizada antes da restituição pretendida pelo contribuinte, momento em que se constata a existência de débitos, os quais serão compensados com o saldo a restituir, podendo, desse modo, a compensação de ofício ser total ou parcial, conforme previsto no artigo $7^{\circ}$ do Decreto-lei $2.287 / 86$ e artigo $89, \S 8^{\circ}$ da Lei $n^{\circ} 8.212 / 91$, ambos com a redação dada pela Lei $\mathrm{n}^{\circ} 11.196 / 05$, dispondo ainda sobre a matéria o artigo 74 da Lei $\mathrm{n}^{\circ}$ 9.430/96 (cf. PAULSEN, Leandro, Curso de Direito Tributário, $1^{\mathrm{a}}$ ed. - Porto Alegre: Livraria do Advogado, 2008, p.192).

${ }^{62}$ Anota Leandro Paulsen que o regime da Lei $n^{\circ}$ 8.383/91 é "aplicável às contribuições previdenciárias e a terceiros (assim entendidos aquelas incidentes sobre a folha de salários, fiscalizadas e cobradas juntamente com as contribuições previdenciárias, mas destinadas a outros entes como o SESI e o INCRA), bem como a tributos não administrados pela Receita Federal do Brasil" (cf. PAULSEN, Leandro. Curso de direito tributário. Porto Alegre: Livraria do Advogado, 2008. p. 193). Ressalte-se que para as contribuições previdenciárias, a compensação é limitada a $30 \%$ do valor a ser recolhido em cada competência, conforme dispõe o $\S 3^{\circ}$, do artigo 39 da Lei $n^{\circ} 9.250 / 95$. 
$\S 4^{\circ}$ As Secretarias da Receita Federal e do Patrimônio da União e o Instituto Nacional do Seguro Social - INSS expedirão as instruções necessárias ao cumprimento do disposto neste artigo.

Percebe-se que a Lei $\mathrm{n}^{\circ} 8.383 / 91$ ampliou as possibilidades de reconhecimento de crédito ao contribuinte, bem como de utilização desse crédito para compensação, inclusive com a possibilidade de se compensar um valor reconhecido como indevido com débitos relativos aos períodos subsequentes.

No entanto, nos termos do $\S 1^{\circ}$ do artigo 66 da Lei $n^{\circ} 8.383 / 91$, tal compensação estava restrita aos "tributos e contribuições da mesma espécie", facultando, em seu parágrafo segundo, ao contribuinte "optar pelo pedido de restituição".

Com o advento da Lei n 9.430 de 27 de dezembro de 1996, a compensação tributária assume novos contornos na esfera federa, com notável ampliação das possibilidades de compensação.

O artigo 74 da Lei $n^{\circ}$ 9.430/96 estabelece que

O sujeito passivo que apurar crédito, inclusive os judiciais com trânsito em julgado, relativo a tributo ou contribuição administrado pela Secretaria da Receita Federal, passível de restituição ou de ressarcimento, poderá utilizá-lo na compensação de débitos próprios relativos a quaisquer tributos e contribuições administrados por aquele Órgão ${ }^{63}$.

Da simples leitura do dispositivo, constata-se a importante alteração em relação à disciplina anterior, pois foi retirada a restrição de que a compensação fosse realizada apenas com créditos de tributos da mesma espécie, bastando fossem eles administrados pela Secretaria da Receita Federal, hoje Receita Federal do Brasil.

Outra inovação foi passar a ser de iniciativa do contribuinte a compensação tributária na esfera federal, efetuada mediante a entrega, pelo sujeito passivo, de uma "declaração" e não mais um "pedido", devendo constar nessa declaração as informações relativas aos créditos utilizados e aos respectivos débitos compensados ${ }^{64}$. Referida declaração de compensação "extingue o crédito tributário, sob condição resolutória de sua ulterior homologação" ${ }^{65}$. O prazo para o Fisco realizar a homologação é de cinco anos, contados da entrega da declaração de compensação ${ }^{66}$ (homologação tácita).

\footnotetext{
${ }^{63}$ Dispositivo com a redação dada pelo artigo 49 da Lei n ${ }^{\circ} 10.637$, de 30 de dezembro de 2002.

${ }^{64}$ Artigo $74, \S 1^{\circ}$ da Lei ${ }^{\circ} 9.430 / 96$.

${ }^{65}$ Artigo 74, $\S 2^{\circ}$ da Lei $n^{\circ} 9.430 / 96$.

${ }^{66}$ Artigo $74, \S 5^{\circ}$ da Lei ${ }^{\circ} 9.430 / 96$.
} 
Na hipótese de não homologação da compensação declarada nos termos acima, é facultado ao sujeito passivo, no prazo de 30 dias, apresentar manifestação de inconformidade, dotada esta de efeito suspensivo ${ }^{67}$.

A Lei $n^{\circ}$ 9.430/96 também estabelece expressamente os casos em que não se admite a compensação tributária por meio de declaração do contribuinte. Nessas hipóteses a declaração de compensação não poderá ser objeto de homologação, sendo considerada como "não declarada" ${ }^{68}$, persistindo a cobrança do crédito tributário. Ademais, eventual recurso interposto contra o ato da Administração Tributária que considera "não declarada" a compensação não será dotado de efeito suspensivo ${ }^{69}$.

Várias são as possibilidades de uma "compensação" ser considerada "não declarada"; porém, dado o escopo deste trabalho, destacam-se a que veda a compensação em que o crédito apresentado pelo sujeito passivo seja de terceiros e as que se refiram a "crédito-prêmio", instituído pelo art. $1^{\circ}$ do Decreto-Lei n ${ }^{\circ} 491$, de 5 de março de $1969^{70}$, ou a título público (artigo 74, $\S 12$, inciso II, alíneas $a, b$ e $c$, da Lei ${ }^{\circ}$ 9.430/96).

Observa-se, portanto, que a legislação que regulamenta a compensação tributária esfera federal não só exige que a declaração de compensação seja lastreada em crédito tributário (decorrente do reconhecimento do pagamento indevido), eis que veda a utilização de "crédito-prêmio" e títulos públicos, como também impõe que este crédito tributário não seja de terceiros, inviabilizando a cessão de créditos tributários para fins de compensação tributária.

Dessa maneira, em âmbito federal, a legislação reforça a ideia de que, na compensação tributária, sempre se procurou estabelecer uma relação entre o indébito tributário e o crédito tributário.

Em síntese, tem-se que a compensação em Direito Tributário é restrita, exigindo regulamentação por legislação específica, nos termos do artigo 170 do Código Tributário Nacional. Ademais, inferiu-se que a compensação tributária guarda relação direta com a repetição do indébito tributário, notadamente no que tange à perfeita identidade dos sujeitos da relação obrigacional.

${ }_{67}^{67}$ Artigo $74, \S \S 7^{\circ}, 9^{\circ}$ e 11 da Lei $n^{\circ} 9.430 / 96$.

${ }^{68}$ Artigo 74, $\S \S 3^{\circ}$ e 12 da Lei ${ }^{\circ} 9.430 / 96$.

${ }^{69}$ Artigo 74, § 13 da Lei ${ }^{\circ} 9.430 / 96$.

${ }^{70}$ O Supremo Tribunal Federal, ao julgar caso com repercussão geral reconhecida, concluiu que o "incentivo fiscal (crédito-prêmio) deixou de vigorar dois anos após a promulgação da Constituição Federal de 1988, como determinou o art. 41 do Ato das Disposições Constitucionais Transitórias, pois não foi confirmado por lei, extinguindo-se, desta forma, em 1990.” (AI 617694 AgR, Rel. Ministra Ellen Gracie, Segunda Turma, julgado em 08/09/2009). 
De todo modo, não há no ordenamento jurídico restrição quanto à possibilidade de compensação tributária com créditos que não tenham natureza tributária (aqueles não decorram do indébito tributário).

Assim, sem perder o foco deste estudo, mostra-se relevante verificar quais são as balizas impostas à compensação tributária com créditos que não decorram de indébito tributário, especialmente pelo fato é nessa hipótese de compensação, de acordo com o que será exposto adiante, que se poderia incluir o precatório. É o que se passa a fazer.

\subsubsection{A compensação tributária com outros créditos (créditos não relacionados ao indébito tributário)}

A legislação tributária, conforme visto acima, sempre procurou aproximar a compensação tributária à repetição do indébito tributário, apesar de o artigo 170 do CTN não exigir que o crédito levado à compensação decorresse de indébito tributário, bastando que este fosse do sujeito passivo contra a Fazenda pública, além, é claro, de ser líquido e certo, e vencido ou vincendo.

É que ao tratar a compensação tributária dessa maneira, restringindo-a ao indébito tributário, evitou-se qualquer discussão acerca das relações obrigacionais que seriam contrapostas, bem como do próprio crédito levado ao procedimento compensatório, bastando que o sujeito passivo fosse titular de crédito que já tivesse sido reconhecido como "indébito tributário".

Entretanto, como adiantado acima, é possível, e por vezes até obrigatório, que o ordenamento jurídico vigente contemple compensações tributárias com créditos não relacionados ao indébito tributário.

Por essa razão, impende investigar os requisitos para realização dessa modalidade de compensação, na medida em que é nessa hipótese que se vislumbra a possibilidade de se utilizar um precatório judicial com o objetivo de extinguir o crédito tributário.

Um caso importante de compensação tributária com crédito não relacionado ao indébito tributário é a que decorre da regra da "não-cumulatividade", prevista inicialmente na Constituição da República de 1988 para o Imposto sobre Produtos Industrializados - IPI (artigo $153, \S 3^{\circ}$, inciso II) e para o Imposto sobre as operações relativas à circulação de 
mercadorias e sobre prestação de serviços de transporte interestadual e intermunicipal e de comunicação - ICMS (artigo 155, §2 $2^{\circ}$ inciso I) e, posteriormente, ampliada para as contribuições sociais incidentes sobre a receita ou o faturamento, bem como para as devidas pelo importador de bens ou serviços do exterior, ou de quem a lei a ele equiparar (artigo 195, §12, com a redação dada pela Emenda Constitucional n. 42/03) ${ }^{71}$.

A técnica de apuração da não-cumulatividade tem por finalidade desonerar a cadeia produtiva ou de circulação de produtos e serviços, evitando a ocorrência do "efeito cascata" resultante do repasse do ônus tributário incidente em cada etapa do ciclo ao preço final do produto ou serviço, haja vista a característica plurifásica da tributação nessas hipóteses. A manutenção da sobrecarga tributária é indesejável economicamente para todo o país ${ }^{72}$, motivo pelo qual optou o legislador por tratar da matéria em sede constitucional.

No caso do IPI, por exemplo, é possível que haja a incidência do imposto desde o mero beneficiamento da matéria-prima até o acondicionamento do produto na embalagem que será encaminhada ao comércio, de modo que os valores recolhidos a título do imposto em cada uma dessas etapas da produção seriam repassados à seguinte, aumentando sobremaneira o preço final do produto.

Para evitar tal acumulação de imposto sobre imposto, com o consequente repasse do encargo financeiro para o próximo participante da cadeia de produção, estabeleceu a Constituição da República que o IPI "será não-cumulativo, compensando-se o que for devido em cada operação com o montante cobrado nas anteriores" (artigo 153, §3 $3^{\circ}$ inciso II) ${ }^{73}$.

Nestes termos, o valor cobrado a título de IPI na etapa anterior se torna "crédito" do adquirente do produto, o qual será utilizado em procedimento próprio de "compensação" para abater o valor por ele devido a título de IPI na venda do produto (transformado), neutralizando-se, assim, os efeitos do acúmulo de IPI no preço do produto final.

\footnotetext{
${ }^{71}$ No caso das contribuições sociais a Constituição da República não prevê que o valor cobrado a título de imposto na operação anterior será compensado na etapa subsequente, como faz para o IPI e para o ICMS, apenas estabelecendo que a lei definirá os setores da atividade econômica para os quais as contribuições serão não-cumulativas. Contudo, para o desenvolvimento do presente estudo, as discussões que decorrem dessa diferenciação são irrelevantes.

72 Nesse sentido são os ensinamentos de Roque Antonio Carrazza: "Como, economicamente, o ICMS é transferido para o adquirente, pelo mecanismo dos preços, sua carga tributária acaba sendo suportada, em definitivo, pelo consumidor final. Mas este é simples contribuinte de fato, já que não integra a relação jurídica tributária. Nesta acepção -meramente econômica -, o ICMS (tanto quanto o IPI) é um imposto que onera o consumo." (CARRAZZA, Roque Antonio. ICMS. 14. ed. São Paulo: Malheiros, 2009. p. 357)

${ }^{73} \mathrm{O}$ mesmo comando é dado ao ICMS no artigo $155, \S 2^{\circ}$, inciso I da Constituição da República.
} 
Logo, a regra da não-cumulatividade do IPI pressupõe a regular incidência e recolhimento do imposto em todas as etapas do ciclo produtivo. Tanto é assim que a Constituição Federal utiliza a expressão “cobrado nas [operações] anteriores”, permitindose concluir que a "compensação" a que alude o texto constitucional não leva em consideração um "indébito tributário", pois, como visto, o montante recolhido na etapa anterior a título de IPI era devido, e a "compensação" só será permitida se houver a cobrança do imposto na etapa antecedente $\mathrm{e}^{74}$.

Assim, se não há indébito tributário na não-cumulatividade do IPI e do ICMS, a compensação tributária será efetivada com a diminuição do montante de crédito tributário devido na operação realizada pelo valor do crédito gerado na etapa anterior.

Nessa situação, os sujeitos das relações obrigacionais contrapostas são diferentes, assim como é diversa a natureza do crédito, realizando-se tal compensação por determinação expressa da Constituição Federal.

Na hipótese, apesar de se tratar de compensação tributária, não é possível se pensar em um mero encontro de contas, pois tanto o crédito como os sujeitos das relações obrigacionais são distintos.

De fato, a compensação decorrente da não cumulatividade é viabilizada por crédito que foi gerado pela regular cobrança e recolhimento do tributo incidente na etapa anterior. $\mathrm{O}$ ente tributante não tem o dever de restituir o valor recolhido, não há o indébito tributário.

Não há dúvida, portanto, de que seja possível a compensação tributária com créditos que não estejam relacionados a valores indevidamente recolhidos.

De outro lado, é sobremaneira importante observar que nessa hipótese de compensação, não obstante estarem o próprio direito à compensação e os requisitos para a sua realização expressamente assegurados pela Constituição da República (montante

\footnotetext{
${ }^{74}$ Corrobora esse entendimento o julgamento realizado pelo plenário do Supremo Tribunal Federal, no qual restou vedada a compensação, à luz da regra da não-cumulatividade, do montante acumulado no decorrer do ciclo produtivo com os valores devidos a título de IPI se o tributo não incidir em alguma das etapas da cadeia produtiva (RE 475551, Relatora para acórdão Ministra Cármen Lúcia, Tribunal Pleno, 06/05/2009). A única exceção a esse entendimento, reconhecida pelo Supremo Tribunal Federal no acórdão citado, é a versada pelo artigo 11 da Lei n. 9. 779/99, a qual foi teve seus efeitos restringidos às hipóteses em que o produto for isento ou tributado à alíquota zero na etapa anterior, ocorridos após a sua vigência (Resp 860369/PE, Rel. Min. Luiz Fux, Primeira Seção, julgado em 25/11/2009, julgado sob o regime dos recursos repetitivos, nos termos do artigo 543-C do Código de Processo Civil). No caso do ICMS não discussão, pois há previsão expressa da Constituição Federal estabelecendo que os casos de isenção ou de não incidência, salvo disposição em lei em sentido contrário, não implicam crédito relativos às operações anteriores (artigo 155, $\S 2^{\circ}$, inciso II, alíneas $a$ e $b$ ).
} 
cobrado na etapa anterior, artigos $153, \S 3^{\circ}$,II e $155, \S 2^{\circ}$, I), a sua efetivação está condicionada à regulamentação por meio de uma lei específica.

A imprescindibilidade de lei específica regulamentando a compensação não é mera exigência formal do artigo 170 do Código Tributário Nacional, ao contrário, é a lei específica que assegurar a própria aplicabilidade da regra da não-cumulatividade no caso concreto, pois sem a regulamentação pormenorizada de uma lei não seria possível se operacionalizar a desoneração pretendida pela não-cumulatividade, tendo em vista que tanto o ICMS como IPI são impostos complexos, sendo necessária a construção de uma regra-matriz de incidência tributária para cada fato descrito na hipótese de incidência, como por exemplo, na importação ou em uma operação interestadual (para o ICMS).

A lei específica que regulamentará a compensação decorrente da aplicação da regra da não-cumulatividade deverá ser editada pelos detentores de competência tributária, a União no caso do IPI e os Estados-membros e Distrito Federal para o ICMS.

Anote-se que para o ICMS, dado o seu caráter nacional, há disposição expressa da Constituição da República, no artigo 155, § $2^{\circ}$, XII, $c$, determinando caber à lei complementar "disciplinar o regime de compensação do imposto". Assim, a lei complementar estabelecerá as regras gerais para a compensação, norteando a elaboração das leis estaduais e distrital.

Outro ponto a ser observado em relação à não-cumulatividade do IPI e do ICMS é o fato de que a compensação é essencial estes aos impostos, já estando inclusive prefigurada no desenho constitucional da competência tributária outorgada à União (IPI) e aos Estados e Distrito Federal (ICMS), de modo que a própria instituição e cobrança desses impostos estará condicionada à previsão de regulamentação da não-cumulatividade ${ }^{75}$.

Portanto, só poderá ser cobrado o IPI e o ICMS se no mesmo instante em que a cobrança for intentada já estiver em vigor uma lei operacionalizando a não-cumulatividade.

Disso se infere que a compensação decorrente da não-cumulatividade não decorre de uma faculdade do detentor da competência tributária, antes, lhe é imposta pela Constituição da República.

\footnotetext{
${ }^{75}$ Nessa linha são os ensinamentos do professor Paulo de Barros Carvalho, que retira a facultatividade do rol de características da competência tributária, sustentando que o ICMS, imposto de competência estadual, apresenta caráter nacional, o que impediria que o titular da competência impositiva deixasse de legislar, sob pena de deflagração de verdadeira "guerra fiscal", e conseqüente abalo ao sistema federativo (CARVAlHO, Paulo de Barros. Curso de direito tributário. 22. ed. São Paulo: Saraiva, 2010. p. 273).
} 
Ora, se a não-cumulatividade é inerente ao ICMS e ao IPI, e para se operacionalizar a compensação dela decorrente exige-se lei (em sentido estrito), o que fazer na hipótese de omissão legislativa? Ou seja: é juridicamente possível uma lei instituidora desses impostos que não contenha previsão sobre a sistemática de créditos e compensações (incidência não cumulativa) constitucionalmente exigida?

Roque Antonio Carrazza ${ }^{76}$ parece responder a essa indagação quando leciona que se lhe for negado o direito de ver abatido, ao pagar o imposto, o montante de ICMS devidos nas operações ou prestações anteriores, o contribuinte poderá, com base exclusivamente na Lei Maior, fazer valer o seu direito constitucional à não-cumulatividade.

Assim, o contribuinte que eventualmente não pudesse se valer da regra da nãocumulatividade em razão de uma omissão da lei instituidora do imposto poderia pleitear judicialmente a inaplicabilidade dessa lei por manifesta inconstitucionalidade. Do mesmo modo, os legitimados do rol do artigo 103 da Constituição da República poderiam ajuizar ação direta de inconstitucionalidade requerendo a retirada da lei que contenha a omissão do ordenamento jurídico de normas válidas e vigentes.

Ou seja, sendo a não-cumulatividade essencial ao IPI e ao ICMS, não se afigura possível a instituição e cobrança desses impostos sem a regulamentação legal da regra constitucional da não cumulatividade.

Em síntese, para o IPI e para o ICMS, a própria Constituição da República estabelece hipótese obrigatória de compensação tributária com créditos não oriundos de procedimento de repetição do indébito tributário. Contudo, tal determinação constitucional não dispensa a edição de lei regulamentadora específica.

Há também hipóteses de compensação tributária com crédito não decorrente de indébito tributário inseridas no campo de discricionariedade do detentor da competência tributária.

É o caso da compensação, embora tratada como "pagamento", prevista pela Lei $\mathrm{n}^{\circ}$ 14.097/2005 do Município de São Paulo ${ }^{77}$, que permitem, em seus artigos $2^{\circ}$ e $3^{\text {o }}$, que o tomador de serviços se valha de parcela do valor recolhido pelo prestador de serviços a título de Imposto sobre Serviços de Qualquer Natureza - ISSQN para quitar débitos de Imposto Predial Urbano - IPTU de imóveis localizados no Município de São Paulo,

\footnotetext{
${ }^{76}$ CARRAZZA, Roque Antonio. ICMS. 14. ed., São Paulo: Malheiros, 2009. p. 356.

${ }^{77}$ Com as alterações introduzidas pelas Leis $n^{\circ} 14.256 / 2006,14.449 / 2007$ e 14.865/2008.
} 
limitado tal valor a cinqüenta por cento do valor do débito de IPTU, não sendo exigido que os imóveis que receberão o abatimento sejam de propriedade do tomador do serviço.

Ou seja, parte do valor recolhido a título de ISSQN é considerado crédito passível de ser utilizado em procedimento de compensação tributária (quitação de IPTU).

Referida compensação foi idealizada como forma de incentivar a emissão de notas fiscais de prestação de serviços no Município de São Paulo, com a consequente diminuição da sonegação fiscal.

Logo, o Município de São Paulo, por sua conveniência, e nos termos da lei citada, permitiu o "pagamento" do IPTU, ainda que de forma parcial, fosse realizado por coisa diversa de dinheiro - parcela de ISSQN recolhido pelo prestador dos serviços contratados por quem pediu a nota fiscal paulistana.

Note-se que na hipótese normativa acima mencionada, não há "pagamento" de IPTU no sentido estrito do artigo 156, inciso I do CTN, mas verdadeira compensação realizada com crédito não decorrente de repetição do indébito, uma vez que o ISSQN que incidiu era devido, e o crédito para a compensação só foi gerado porque houve regular pagamento.

Trata-se, pois, de compensação de tributos com créditos não decorrentes de indébito tributário, previsto em lei específica, emanada do titular da competência tributária, a partir da sua conveniência.

Do mesmo modo, o Estado de São Paulo com o declarado objetivo de "incentivar os adquirentes de mercadorias, bens e serviços de transporte interestadual e intermunicipal a exigir do fornecedor a entrega de documento fiscal hábil”, instituiu por meio da Lei Paulista $n^{\circ}$ 12.685/07 o "Programa de Estímulo à Cidadania Fiscal do Estado de São Paulo", que, dentre outras coisas, estabelece que o consumidor que adquirir mercadorias ou serviços de contribuintes do Imposto sobre Circulação de Mercadorias, Bens e Prestação de Serviços de Transporte Interestadual e Intermunicipal - ICMS terá direito a créditos do Tesouro do Estado (artigo $2^{\circ}$ ), que poderão ser utilizados para reduzir o valor do débito do Imposto sobre a Propriedade de Veículos Automotores - IPVA do exercício seguinte (artigo $5^{\circ}$, inciso I) ${ }^{78}$.

\footnotetext{
${ }^{78}$ Há outras possibilidades de utilização desses créditos previstos na Lei Paulista ${ }^{\circ} 12.685 / 07$, tais como: transferir os créditos para outra pessoa natural ou jurídica, solicitar depósito dos créditos em conta corrente ou poupança, mantida em instituição do Sistema Financeiro Nacional, ou ainda utilizar os créditos em outras finalidades, conforme disciplina a ser estabelecida pelo Poder Executivo.
} 
No exemplo do Estado de São Paulo fica ainda mais nítida a ideia da discricionariedade conferida ao detentor da competência tributária, pois este poderá abrir mão do pagamento do IPVA em moeda corrente, permitindo a sua efetivação, ainda que parcial, por meio de compensação com "créditos do Tesouro do Estado", tendo em vista um objetivo maior que faça parte de sua política fiscal.

Diante dessas considerações, pode-se concluir que é possível, e o ordenamento contempla, hipótese de compensação tributária com créditos não tributários (que não decorram do indébito tributário). Ademais, contatou-se que há compensações que são de necessária observância pelo detentor da competência tributária e outras que poderão serão instituídas de acordo com a sua conveniência, exigindo-se, no entanto, regulamentação em legislação específica para todos os casos. 


\title{
2 O PAgAMENTO DA díVIDA PÚbliCA DECORRENTE DE DECISÃo JUDICIAL - O REGIME DOS PRECATÓRIOS
}

A realização de créditos pecuniários contra a Fazenda Pública, não obstante seja ela presumidamente solvente, não segue o procedimento aplicável aos particulares, pois às Fazendas Públicas não se estendem as regras que dão efetividade à execução de quantia certa contra credor solvente, como a penhora e a alienação de bens em hasta pública, na medida em que os bens públicos se revestem de impenhorabilidade e inalienabilidade.

De outro lado, o pagamento de qualquer dívida pela Fazenda Pública exige elevado grau de certeza quanto ao débito e ao credor, seja pelo simples fato de que se trata de recurso público gerado por toda a sociedade para ser utilizado no seu interesse, ou mesmo para que se evite possível tratamento desigual entre os detentores de crédito contra o ente público.

Assim, em razão do cuidado que se deve ter na gestão de recursos públicos, e levando-se em consideração que os bens públicos são impenhoráveis e inalienáveis, adotase para a execução contra a Fazenda Pública um regramento específico, que impõe o pagamento da dívida pública por meio de precatório, nos termos do artigo 100 da Constituição da República de 1988 e dos artigos 730 e 731 do Código de Processo Civil.

Nesse sentido leciona Leonardo José Carneiro da Cunha $^{79}$ :

\begin{abstract}
Nesse caso, ou seja, sendo o executado a Fazenda Pública, não se aplicam as regras próprias da execução por quantia certa contra devedor solvente, não havendo a adoção de medidas expropriatórias para a satisfação do crédito. Diante da particularidade e da situação da Fazenda Pública, a execução por quantia por quantia certa contra ela intentada contém regras próprias. Põe-se em relevo, no particular, a instrumentalidade do processo, a impor adequação procedimental, na exata medida em que as exigências do direito material na disciplina das relações jurídicas que envolvem a Fazenda Pública influenciam e ditam as regras processuais. Isso porque os pagamentos feitos pela Fazenda Pública são despendidos pelo Erário, merecendo tratamento específico a execução intentada contra as pessoas jurídicas de direito público, a fim de adaptar as regras pertinentes à sistemática dos precatórios.
\end{abstract}

Na mesma linha também é o entendimento de Celso Ribeiro Bastos e Ives Gandra da Silva Martins ${ }^{80}$ :

${ }^{79}$ CUNHA, Leonardo José Carneiro da. A fazenda pública em juízo. 8. ed. São Paulo: Dialética, 2010. p. 271.

${ }^{80}$ BASTOS, Celso Ribeiro; MARTINS, Ives Gandra da Silva. Comentários à constituição do Brasil. v. 4. t. III. 2. ed. São Paulo: Saraiva, 2000. p. 116. 


\begin{abstract}
é de notar-se que se os bens públicos fossem penhoráveis, como são os bens dos particulares, não haveria necessidade de precatório. Este só foi criado em virtude da impenhorabilidade desses bens. A propósito, o precatório tem sua origem no direito processual civil, mais precisamente na prática forense. Ao que parece, sua forma mais rudimentar nasceu da imaginação de um juiz diante de um problema surgido na execução da sentença contra uma Câmara Municipal, em que um particular pleiteava o pagamento de certa quantia. A impenhorabilidade dos bens públicos não poderia isentar a Fazenda Pública de pagar o seu débito. $O$ engenhoso magistrado resolveu a questão expedindo precatória de vênia, com o que determinou a penhora do próprio dinheiro da tesouraria da Câmara. Surgia, assim, a forma primitiva de requisição que seria mais tarde encampada pelo precatório.
\end{abstract}

O regime de precatório para o pagamento da dívida pública decorrente de decisão judicial, como se verá adiante, é aplicável às "Fazendas Públicas Federal, Estaduais, Distrital e Municipais" por expressa disposição do artigo 100, caput, da Constituição Federal de 1988.

Note-se que, em virtude da locução "Fazendas Públicas", do citado dispositivo constitucional, estão abrangidas pelo regime especial dos precatórios todas as situações em que a dívida pública decorrente de decisão judicial é de responsabilidade do erário, incluindo-se, neste regime, portanto, as autarquias e fundações públicas ${ }^{81}$.

Também por esse motivo não estão subordinadas à sistemática dos precatórios as empresas públicas e as sociedades de economia mista, eis que sujeitas ao regime jurídico próprio das empresas privadas, de acordo com o artigo 173 da Constituição da República. A Empresa Brasileira de Correios e Telégrafos - ECT é exceção a essa regra, pois, apesar de ser empresa pública, goza do privilégio da impenhorabilidade de seus bens, determinada pelo artigo 12 do Decreto-lei $n^{\circ}$ 509/1969, recepcionado pela Constituição de 1988, submetendo-se, dessa forma, ao pagamento de suas dívidas também por meio dos precatórios, conforme jurisprudência do Supremo Tribunal Federal ${ }^{82}$ e do Superior Tribunal de Justiça ${ }^{83}$.

Em vista disso, tem-se que a dívida das Fazendas Públicas decorrente de decisões judiciais transitadas em julgado, deverá ser quitada por meio de precatórios, os quais possuem sistemática própria de pagamento determinada pela Constituição da República ${ }^{84}$.

${ }^{81}$ Cf. ASSIS, ARAKEN. Manual da execução. 14. ed. rev. atual. ampl. São Paulo: RT, 2012. p.1101.

${ }^{82}$ RE 230.051, Relator Min. Maurício Corrêa, Tribunal Pleno, DJ 08-08-2003 e RE 225011, Relator Min. Marco Aurélio, Relator p/ Acórdão Min. Maurício Corrêa, Tribunal Pleno, DJ 19-12-2002.

${ }^{83}$ REsp 397.853/CE, Rel. Ministro Franciulli Netto, Segunda Turma, DJ 24/11/2003 e REsp 463.324/PE, Rel. Ministro Ruy Rosado de Aguiar, Quarta Turma, DJ 16/12/2002.

${ }^{84}$ Anote-se que a sistemática diferenciada de pagamento da dívida pública por meio de precatórios, conforme melhor se verá adiante, é matéria tratada em sede constitucional desde a Constituição da República dos Estados Unidos do Brasil de 1934. 
A disciplina constitucional e legal do precatório será analisada no tópico subsequente, motivo pelo qual, passa-se a definir o termo "precatório".

\subsection{O precatório}

O "precatório" é uma a ordem de pagar quantia certa decorrente de decisão judicial transitada em julgado contra a Fazenda Pública, emitida pelo Presidente do Tribunal nos estritos termos da solicitação a ele dirigida pelo do juízo da execução ${ }^{85}$.

Leciona José Cretella Júnior ${ }^{86}$ que o termo "precatório" origina do "vocábulo precatoriu $(\mathrm{m})$, cognato do verbo depoente, precor (= pedir, rogar, solicitar)" e tem o significado de "carta ou requisição expedida ao Presidente do Tribunal pelo magistrado da execução da sentença, em que a Fazenda Pública foi condenada a pagamento de quantia líquida e certa, a fim de que se expeçam as necessárias ordens de pagamento às repartições pagadoras."

O "precatório" na prática forense é também nomeado "precatório requisitório". Acerca dessa nomenclatura, Américo Luís Martins da Silva ${ }^{87}$ explica que a requisição seria a determinação do juiz para que a parte realize determinado ato, enquanto o precatório

${ }^{85}$ Algumas definições de precatório: "Precatório ou ofício precatório é a solicitação que o juiz da execução faz ao presidente do tribunal respectivo para que este requisite verba necessária ao pagamento de credor de pessoa jurídica de direito público, em face de decisão judicial transitada em julgado" (OLIVEIRA, Régis Fernandes de. Curso de direito financeiro. 2. ed. São Paulo: Revista dos Tribunais, 2008. p. 534); “o precatório ou requisitório não passa de uma carta de sentença, processada perante o presidente do Tribunal, consoante normas regimentais" (JUNIOR, Humberto Teodoro. Comentários ao código de processo civil. v. 4. Rio de Janeiro: Forense, 1979. p. 536); “O precatório é uma ordem de pagar quantia certa decorrente de decisão judicial transitada em julgado contra a Fazenda Pública” (SCAFF, Fernando Facury. O uso de precatórios para pagamento de tributos. In: ROCHA, Valdir de Oliveira (coord.). Grandes questões atuais de direito tributário. v. 13. São Paulo: Dialética, 2009. p. 102); "o Precatório é a requisição formal de pagamento que a Fazenda Pública é judicialmente a realizar.” (ABRAHAM, Marcus. Reflexões sobre a EC 62/2009: a compensação de precatórios com créditos da Fazenda Pública. Revista tributária e de finanças públicas, São Paulo: RT, a. 18, n. 94, set.-out. 2010. p. 230); “Os chamados precatórios requisitórios são o instrumento através do qual os juízes de Direito requisitam aos Tribunais o pagamento de condenações judiciais já acobertadas pelo 'manto' da coisa julgada" (GRUPENMACHER, Betina Treiger. $\mathrm{O}$ uso de precatórios para pagamento de tributos. Revista dialética de direito tributário, São Paulo, n. 175, 2010, p. 35); e "Precatório é uma solicitação, efetuada por meio de ofício, dirigida pelo juiz competente para o processo de execução contra a Fazenda Pública ao Presidente do Tribunal ao qual estiver vinculado para que este requisite verba necessária ao pagamento de crédito contra pessoa jurídica de direito público, decorrente de sentença judicial transitada em julgado" (PIMENTA, Paulo Roberto Lyrio. O Pagamento de Tributos por meio de créditos relativos aos precatórios judiciais. Revista dialética de direito tributário, São Paulo, n. 177, 2010, p. 121).

86 JÚNIOR, José Cretella, Comentários à constituição de 1988. v. VII. Rio de Janeiro: Forense Universitária, 1992. p. 3055.

${ }^{87}$ SILVA, Américo Luís Martins da, Precatório-requisitório e requisição de pequeno valor (RPV). 4. ed. São Paulo: Revista dos Tribunais, 2010. p. 162. 
representaria a solicitação de um juiz a outro (carta judicial) para que este, em seu lugar, determine a realização de certos atos processuais, assim concluindo:

\begin{abstract}
Portanto, se a diligência de requisição parte do juízo da execução especial, ela somente se completa com a intermediação do Presidente do Tribunal, de maneira que o "precatório" é um instrumento no qual se distingue 2 (duas) fases procedimentais: a) a expedição de carta (o instrumento de precatório), encaminhada ao Presidente do Tribunal; b) após registro e tramitação de regularidade perante o Tribunal, a expedição do oficio de requisição ou oficio requisitório dirigido ao órgão público encarregado do cumprimento da condenação pecuniária. Daí o uso da expressão "precatório-requisitório".
\end{abstract}

Identificam-se, pois, na expressão precatório-requisitório, duas fases bem delimitadas na sistemática dos precatórios, sendo a primeira relativa à sua expedição, formação e autuação, e a segunda referente à emissão de ofício de requisição de pagamento pelo Presidente do Tribunal à pessoa jurídica de direito público responsável pelo débito.

Isso porque a competência para expedir o ofício requisitando a disponibilização dos valores para o pagamento dos precatórios é do Presidente do Tribunal de origem, aquele em que a decisão contrária à Fazenda Pública transitou em julgado. Já o processo de execução, com todos os atos a ele inerentes, é de competência do juiz singular.

O precatório, desse modo, nada mais é do que a carta expedida pelo juízo da execução, endereçada ao Presidente do Tribunal, para que este emita ordem de pagamento aos órgãos da administração pública responsáveis pela quitação da dívida decorrente de decisões judiciais.

Daí porque na sistemática dos precatórios há uma troca de informações no âmbito do Poder Judiciário semelhante a que se verifica com a expedição de carta precatória, que é o instrumento utilizado para a comunicação e solicitação de providências entre juízes de diferentes localidades. Explica-se: na carta precatória, o intercâmbio jurisdicional se dá em virtude dos limites territoriais da jurisdição, no precatório, por sua vez, o intercâmbio decorre da limitação funcional ${ }^{88}$.

Não por outro motivo, Oscar Joseph De Plácido e Silva ${ }^{89}$ define o precatório como “cartas expedidas pelos juízes da execução aos Presidentes dos Tribunais de Justiça, a fim

\footnotetext{
${ }^{88}$ Cf. Ibidem. p. 164-165.

${ }^{89}$ Cf. DE PLÁCIDO E SILVA, Oscar Joseph. Comentários ao código de processo civil. 3. ed. v. 4.Curitiba /Rio de Janeiro/São Paulo: Guaíra: 1948. p. 1766-1767 apud SILVA, Américo Luís Martins da. Precatório-requisitório e requisição de pequeno valor (RPV). 4. ed. rev. atual. ampl. São Paulo: Revista dos Tribunais, 2010. p. 163.
} 
de que, por seu intermédio, se autorizem e se expeçam as respectivas ordens de pagamento às repartições pagadoras" ${ }^{\prime 90}$.

Havia certa discussão doutrinária sobre a natureza jurídica dos atos praticados pelo presidente de um tribunal relativos à administração dos precatórios, se jurisdicional $^{91}$ ou administrativa.

Hoje está consolidado o entendimento de que tanto os atos praticados pelo juiz da execução como aqueles de competência do presidente do tribunal são considerados atos administrativos, na medida em que destituídos de caráter jurisdicional.

É o que se depreende da súmula 311 do Supremo Tribunal Federal, que estabelece que "os atos do presidente do tribunal que disponham sobre o processamento e pagamento de precatório não têm caráter jurisdicional". Ressalte-se que esse entendimento foi reafirmado no julgamento de ADI 1.098/SP $\mathrm{SP}^{92}$.

Da ausência de atividade jurisdicional nos atos praticados pelo presidente do tribunal na administração de precatórios, conclui-se pela impossibilidade de impugná-los por meio de recursos extraordinário e especial. Nessa esteira é a súmula 733 do Supremo Tribunal Federal: "Não cabe recurso extraordinário contra decisão proferida no processamento de precatórios".

Como alternativa, defende Araken de Assis que tais atos seriam passíveis de controle através de mandado de segurança ${ }^{93}$. Esse entendimento é igualmente esposado por Fredie Didier Jr., Leonardo J. C. Cunha, Paula Sarno Braga e Rafael Oliveira ${ }^{94}$ :

\footnotetext{
Justamente por ser administrativa a atividade do presidente no processamento do precatório, não cabe a interposição nem de recurso especial, nem de recurso extraordinário, mas se revela possível a impetração de mandado de segurança contra alguma determinação tida por ilegal ou abusiva.
}

\footnotetext{
${ }^{90}$ Nessa linha também é o conceito de precatório proposto por Américo Luís Martins da Silva, para quem: “o precatório é uma carta expedida pelo juízo do processo de execução, em virtude dos limites de sua competência funcional, dirigida ao presidente do Tribunal a que é imediatamente subordinado, a fim de que seja, por seu intermédio, autorizado e expedido ofício à pessoa jurídica de direito público executada, através do qual determina o pagamento de quantia requisitada pelo juízo de origem". (SILVA, Américo Luís Martins da. Precatório-requisitório e requisição de pequeno valor (RPV). 4. ed. rev. atual. ampl. São Paulo: Revista dos Tribunais, 2010. p. 166).

${ }^{91}$ Cf. FREDERIGHI, Wanderley José. A execução contra a Fazenda Pública. São Paulo: Saraiva, 1996. p. 59.

${ }^{92}$ ADI 1098/SP. Rel. Min. Marco Aurélio, Tribunal Pleno, julgado em 14/12/1994, DJ 28-04-1995.

${ }^{93}$ Cf. ASSIS, ARAKEN. Manual da Execução. 14. ed. rev. atual. ampl. São Paulo: RT, 2012. p.1108.

94 DIDIER JUNIOR, Fredie; CUNHA, Leonardo José Carneiro da; BRAGA, Paula Sarno; OLIVEIRA, Rafael. Curso de direito processual civil: execução. 4. ed. v. 5. Salvador: Jus Podium, 2012 p. 734.
} 
Definido o precatório, apontando-se as suas principais características, passa-se a investigar o seu regramento constitucional e infraconstitucional.

Reitera-se, apesar de acima já advertido ${ }^{95}$, que a sistemática de pagamento de uma dívida pública decorrente de decisão judicial por meio de precatório é peculiar ao Direito Brasileiro, não havendo similar em legislação estrangeira ou tratamento análogo no direito comparado $^{96}$.

\subsection{O Precatório no Direito Constitucional Brasileiro}

O instituto do precatório foi criado no final do século XIX pela legislação processual brasileira (Decreto 3.084, de 05 de novembro de 1898) ${ }^{97}$, porém a sistemática de pagamento da dívida pública por meio de precatórios foi constitucionalmente disciplinada pela primeira vez na Constituição de 1934, sendo mantida em sede constitucional em todas as Constituições posteriores. Por essa razão, cuida-se neste estudo apenas do precatório à luz da Constituição.

${ }^{95}$ Pede-se vênia para repetir nota de rodapé da apresentação: "Nesse sentido: FLAKS, Milton. Precatório judiciário na constituição de 1988. Revista de processo. n. 58, a. 15, São Paulo: RT, 1990. p. 87; VIANA, Juvêncio Vasconcelos. Execução contra a fazenda pública. São Paulo: Dialética, 1998. p. 64; e DANTAS, Francisco Wildo Lacerda. Execução contra a fazenda pública: regime de precatório. 2. ed. São Paulo: Método, 2010. p. 86. Observa Marçal Justen Filho que no direito comparado, a matéria não é objeto de disciplina em nível constitucional e não merece tratamento diferenciado daquele reservado para o pagamento das dívidas dos particulares (cf. Estado democrático de direito e responsabilidade civil do estado: a questão dos precatórios. Biblioteca Digital Revista de Direito Público da Economia - RDPE, Belo Horizonte, a. 5, n. 19, jul. 2007)".

${ }^{96}$ Francisco Wildo Lacerda Dantas chama a atenção para o Uruguai, apontando ser esse país o único a ter um regramento próximo ao do Brasil, especificamente no tocante à execução contra a Fazenda Pública, sem, contudo, estar a matéria tratada em sede constitucional, ficando restrita ao Código General del Processo de la República del Uruguai, Lei 16.170/90, alterada pela Lei 15.982/99. (DANTAS, Francisco Wildo Lacerda. Execução contra a fazenda pública: regime de precatório. 2. ed. São Paulo: Método, 2010. p. 200-201).

${ }^{97}$ Cf. ABRAHAM, Marcus. Reflexões sobre a EC 62/2009: a compensação de precatórios com créditos da Fazenda Pública. Revista tributária e de finanças públicas, São Paulo: RT, a. 18. n. 94. Set.-out. 2010. p. 230 . 


\title{
2.2.1 Evolução constitucional da disciplina do precatório
}

A Constituição de 1934 regrava o pagamento da dívida pública por meio do precatório em seu artigo 182 , que estabelecia que ${ }^{98}$ :

\begin{abstract}
os pagamentos devidos pela Fazenda federal, em virtude de sentença judiciária, far-se-ão na ordem de apresentação dos precatórios e à conta dos créditos respectivos, sendo vedada a designação de caso ou pessoas nas verbas legais.

Parágrafo único - Estes créditos serão consignados pelo Poder Executivo ao Poder Judiciário, recolhendo-se as importâncias ao cofre dos depósitos públicos. Cabe ao Presidente da Corte Suprema expedir as ordens de pagamento, dentro das forças do depósito, e, a requerimento do credor que alegar preterição da sua precedência, autorizar o seqüestro da quantia necessária para o satisfazer, depois de ouvido o Procurador-Geral da República.
\end{abstract}

Até a vigência da Constituição de 1934, os pagamentos devidos pela Fazenda Pública Federal em decorrência das condenações judiciais processavam-se perante as autoridades administrativas federais (Ministério da Fazenda e Tesouro Nacional), as quais, por sua vez, enviavam ao Congresso Nacional a inclusão dos respectivos necessários ao pagamento das dívidas judiciais ${ }^{99}$.

Contudo, esses pagamentos não eram realizados em uma pré-determinada ordem, como a cronológica, o que permitia toda sorte de abusos e irregularidades, principalmente de advocacia administrativa.

Portanto, mostrou-se salutar à moralidade administrativa a previsão constitucional do citado artigo 182, de que os pagamentos de precatórios seriam realizados na ordem de sua apresentação, sendo vedada a designação de casos e pessoas nas verbas destinadas ao seu pagamento. Nessa esteira também o parágrafo único do artigo 182, que autorizou o sequestro da quantia devida em caso de preterição da ordem de pagamento.

José Augusto Delgado ${ }^{100}$ sustenta que o "O surgimento do precatório, na Carta de 1934, por se constituir em expediente processual pioneiro em nosso ordenamento, se

98 Anote-se a pontual observação de Ricardo Perlingeiro Mendes da Silva: "Vale frisar que a novidade da Constituição de 1934 não foi propriamente o surgimento do precatório, mas sim a sua previsão constitucional com a exigência da observância da ordem cronológica, pois sistema semelhante ao precatório judicial já existia por força do artigo 14 da Instrução Normativa de 10 de abril de 1851, do Directorio do Juízo Fiscal e Contencioso dos Feitos da Fazenda." (SILVA, Ricardo Perlingeiro Mendes da. Execução contra a fazenda pública. São Paulo: Malheiros, 1999. p. 31).

${ }^{99}$ Cf. SILVA, Américo Luís Martins da. Precatório-requisitório e requisição de pequeno valor (RPV). 4. ed. São Paulo: Revista dos Tribunais, 2010. p. 73.

${ }^{100}$ DELGADO, José Augusto. In: Revista de Processo, n. 57, a, 15, São Paulo: Revista dos Tribunais, 1990, p. 13. 
revestiu de determinada timidez." Demonstrando a aludida timidez constitucional, o autor $^{101}$ assinala os seguintes aspectos:

a)só se referiu aos pagamentos devidos pela Fazenda Federal, deixando, consequentemente, ao sabor das Constituições estaduais os débitos dos Estados e Municípios; b) o total do crédito orçamentário destinado ao pagamento dos precatórios ficava a critério do Poder Executivo Federal, o que, na prática, resultava em um controle direto do referido Poder sobre o quantitativo da dívida reconhecida pelo Poder Judiciário, causando, consequentemente, imensa demora na liquidação do processo executivo; c) o Presidente da Suprema Corte era a única autoridade judicial que tinha competência para expedir as ordens de pagamento, dentro das forças do depósito.

A Constituição de 1937 não alterou o modelo de pagamento dos precatórios instituído pela sua antecessora, motivo pelo qual as críticas acima também lhe são aplicáveis. Apenas insta observar que esta Constituição considerou necessária a inclusão de verba orçamentária específica para os pagamentos decorrentes de sentença judiciais ${ }^{102}$, bem como substituiu a denominação "precatório" para "precatória". A matéria estava prevista no seu artigo 95, in verbis:

\begin{abstract}
os pagamentos devidos pela Fazenda federal, em virtude de sentenças judiciárias, far-se-ão na ordem em que forem apresentadas as precatórias e à conta dos créditos respectivos, vedada a designação de casos ou pessoas nas verbas orçamentárias ou créditos destinados àquele fim.

Parágrafo único - As verbas orçamentárias e os créditos votados para os pagamentos devidos, em virtude de sentença judiciária, pela Fazenda federal, serão consignados ao Poder Judiciário, recolhendo-se as importâncias ao cofre dos depósitos públicos. Cabe ao Presidente do Supremo Tribunal Federal expedir as ordens de pagamento, dentro das forças do depósito, e, a requerimento do credor preterido em seu direito de precedência, autorizar o seqüestro da quantia necessária para satisfazê-lo, depois de ouvido o Procurador-Geral da República.
\end{abstract}

Na Constituição de 1946 o regime dos precatórios era disciplinado pelo artigo 204, o qual imprimiu cinco mudanças em relação às Constituições de 1934 e $1937^{103}$, a seguir analisadas.

A primeira alteração solucionava um dos problemas suscitados por José Augusto Delgado, na medida em que elevava ao patamar constitucional o regramento dos precatórios estaduais e municipais. Com a Constituição de 1946, o pagamento da dívida

\footnotetext{
${ }^{101}$ Ibidem. loc. cit.

${ }^{102}$ Acerca da necessária previsão orçamentária, Américo Luís Martins Da Silva esclarece que "as verbas destinadas à formação do depósito deveriam ser, preliminarmente, votadas e incluídas no orçamento. As verbas orçamentárias e os créditos votados para os pagamentos devidos em virtude de sentença eram, pois, preceitos de ordem constitucional.” (SILVA, Américo Luís Martins da. Precatório-requisitório e requisição de pequeno valor (RPV). 4. ed. rev. atual. ampl. São Paulo: Revista dos Tribunais, 2010. p. 76).

${ }^{103}$ Cf. SILVA, Américo Luís Martins da. Precatório-requisitório e requisição de pequeno valor (RPV). 4. ed. rev. atual. ampl. São Paulo: Revista dos Tribunais, 2010. p. 84-86.
} 
pública estadual e municipal decorrente de decisões judiciais passou a seguir a mesma sistemática dos precatórios federais, que já eram disciplinados pelas Constituições de 1934 e 1937. Dessa alteração decorrem as três últimas que serão apontadas.

A segunda modificação se refere às verbas orçamentárias que eram destinadas ao pagamento da dívida da Fazenda Pública decorrente de sentenças judiciais. Acerca dessa modificação leciona Américo Luís Martins da Silva:

\begin{abstract}
Enquanto a Carta de 1937 usava a expressão "nas verbas orçamentárias ou créditos destinados àquele fim", a Constituição de 1946 usou a expressão "nas dotações orçamentárias e nos créditos extraorçamentários abertos para este fim". Assim, a Carta de 1946 aludia não somente às dotações orçamentárias, como aos créditos extraorçamentários abertos para atenderem os pagamentos requisitados pelo Poder Judiciário para cumprimento de seus decisórios contra a Fazenda Pública ${ }^{104}$.
\end{abstract}

Logo, a Constituição de 1946 ampliou a possibilidade de aplicação de recursos para o pagamento da dívida pública decorrente de sentenças judiciais, permitindo que "créditos extra-orçamentários" fossem utilizados para tal finalidade.

A terceira alteração diz respeito à forma de disponibilização dos valores que seriam utilizados para o pagamento dos precatórios, pois estes não eram mais recolhidos aos “cofres do Depósito Público", mas sim "à repartição competente”. Assim, transferiu-se ao Tesouro Nacional a atribuição de pagar as dívidas da União na Capital, e às Delegacias Fiscais nas demais capitais dos Estados. Já as dívidas estaduais eram pagas pelas próprias tesourarias anexas às Secretarias de Fazenda de cada Estado, sendo também das próprias tesourarias municipais o dever de adimplir a dívida local ${ }^{105}$.

A quarta modificação foi transferir a competência para a expedição de ordens de pagamento do Presidente do Supremo Tribunal Federal para o Presidente do Tribunal Federal de Recursos e, conforme o caso, ao Presidente do Tribunal de Justiça local.

Por fim, a quinta alteração promovida pela Constituição de 1946 se refere aos casos de autorização de sequestro, os quais passaram a depender de prévia oitiva do chefe do Ministério Público local, que poderia ser não ser o Procurador Geral da República, como nas Constituições anteriores, haja vista que a ordem de pagamento no regime de 1946 poderia ser expedida tanto pelo Presidente do Tribunal Federal de recurso como pelo Presidente de Tribunal de Justiça.

O artigo 204 da Constituição de 1946 tem a seguinte redação:

\footnotetext{
${ }^{104}$ Ibidem. p. 84.

${ }^{105}$ Cf. SILVA, De Plácido e. Comentários ao código de processo civil. 3. ed. Rio de Janeiro: Guaíra, 1948. p. 1766.
} 
Os pagamentos devidos pela Fazenda federal, estadual ou municipal, em virtude de sentença judiciária, far-se-ão na ordem de apresentação dos precatórios e à conta dos créditos respectivos, sendo proibida a designação de casos ou de pessoas nas dotações orçamentárias e nos créditos extra-orçamentários abertos para esse fim.

Parágrafo único - As dotações orçamentárias e os créditos abertos serão consignados ao Poder Judiciário, recolhendo-se as importâncias à repartição competente. Cabe ao Presidente do Tribunal Federal de Recursos ou, conforme o caso, ao Presidente do Tribunal de Justiça expedir as ordens de pagamento, segundo as possibilidades do depósito, e autorizar, a requerimento do credor preterido no seu direito de precedência, e depois de ouvido o chefe do Ministério Público, o seqüestro da quantia necessária para satisfazer o débito.

A Constituição de 1967 não alterou a sistemática de pagamento dos precatórios que vinham preconizando as constituições anteriores. Entretanto, a Constituição de 1967 introduziu norma de inequívoca importância ao ordenamento jurídico, pois determinou a obrigatoriedade de inclusão no orçamento de verba para o pagamento dos débitos referentes aos precatórios apresentados até o dia primeiro de julho de cada ano (artigo 112, $\left.\S 1^{\circ}\right)$.

Tal alteração tinha como objetivo por fim à alegação de falta de verba como justificativa para a inadimplência das Fazendas Públicas no pagamento dos precatórios.

Acrescenta Américo Luís Martins da Silva que "o dever de inclusão no orçamento da verba para o pagamento dos débitos constantes dos precatórios, apresentados até $1^{\circ}$ de julho, era um dever do Presidente, do Governador de Estado-membro ou do Prefeito. Se não o fazia, cometia crime de responsabilidade." 106

Essa era a redação do artigo 112 da Constituição de 1967:

Os pagamentos devidos pela Fazenda federal, estadual ou municipal, em virtude de sentença judiciária, far-se-ão na ordem de apresentação dos precatórios e à conta dos créditos respectivos, proibida a designação de casos ou de pessoas nas dotações orçamentárias e nos créditos extra-orçamentários abertos para esse fim.

$\S 1^{\circ}$ - É obrigatória a inclusão, no orçamento das entidades de direito público, de verba necessária ao pagamento dos seus débitos constantes de precatórios judiciários, apresentados até primeiro de julho.

$\S 2^{\circ}$ - As dotações orçamentárias e os créditos abertos serão consignados ao Poder Judiciário, recolhendo-se as importâncias respectivas à repartição competente. Cabe ao Presidente do Tribunal, que proferiu a decisão exeqüenda determinar o pagamento, segundo as possibilidades do depósito, e autorizar, a requerimento do credor preterido no seu direito de precedência, e depois de ouvido o chefe do Ministério Público, o seqüestro da quantia necessária à satisfação do débito.

${ }^{106}$ SILVA, Américo Luís Martins da. Precatório-requisitório e requisição de pequeno valor (RPV). 4. ed. São Paulo: Revista dos Tribunais, 2010. p. 90. 
A Emenda Constitucional $\mathrm{n}^{\mathrm{o}} 1$ de 17 de outubro de 1969 manteve inalterada a redação do artigo 112 da Constituição de 1967, reproduzindo-a no seu artigo 117, o qual vigorou até a atual ordem constitucional.

Destarte, resta perquirir o regramento dos precatórios estabelecido com a promulgação da Constituição da República de 1988, bem como as emendas constitucionais que o alteraram.

\subsubsection{O regime dos precatórios na Constituição da República de 1988}

O pagamento da dívida pública decorrente de decisão judicial é disciplinado pelo artigo 100 da Constituição da República de 1988, com as alterações promovidas pelas Emendas Constitucionais 20/1998, 30/2000, 37/2002 e 62/2009 ${ }^{107}$.

A matéria também é regrada pelo Ato das Disposições Constitucionais Transitórias, com a ressalva de que a parte transitória da Constituição Federal cuida do estoque da dívida representada por precatórios, seja aquele existente à época da promulgação da Constituição, como também o consolidado no momento em que promulgadas as emendas constitucionais que estabeleceram o parcelamento e os regimes especiais de pagamento de precatórios.

Em relação à legislação infraconstitucional, destacam-se os artigos 730 e 731 do Código de Processo Civil, que versam sobre a execução movida contra a Fazenda Pública, ambos recepcionados pela Constituição da República de 1988.

Esse é o arcabouço normativo dos precatórios que se passa a analisar, em linhas gerais.

${ }^{107}$ Importante observar que tanto a Emenda Constitucional $\mathrm{n}^{\circ} 20$, de 30 de setembro de 2000, como a Emenda Constitucional $n^{\circ}$ 62, de 9 de dezembro de 2009, estão sendo questionadas em diversas Ações Diretas de Inconstitucionalidade. Cite-se, por exemplo: ADI n ${ }^{\circ} 356$ (julgamento em conjunto com a ADI 2362), na qual foi deferida medida cautelar para suspender a eficácia do artigo $2^{\circ}$ da Emenda Constitucional $n^{\circ} 30 / 2000$, que introduziu o artigo 78 no Ato das Disposições Constitucionais Transitórias da Constituição de 1988 (ADI 2356 MC, Relator Ministro Néri da Silveira, Relator p/ Acórdão Ministro Ayres Britto, Tribunal Pleno, julgado em 25/11/2010, Publicado em 19-05-2011); e a ADI $\mathrm{n}^{\circ} 4357$ (chamada para julgamento em conjunto às Ações Diretas de Inconstitucionalidade $n^{\circ} 4.357,4.372,4.400$ e 4.425) que conta com voto do Ministro Relator, Ayres Britto, pela parcial procedência em relação à inconstitucionalidade da Emenda Constitucional $n^{\circ}$ 62/2009, estando o julgamento aguardando o pedido vista do Senhor Ministro Luiz Fux, em 06/10/2011. 


\subsubsection{O regramento dos precatórios na parte permanente da Constituição Federal}

$\mathrm{O}$ artigo 100, caput da Constituição Federal estabelece que "Os pagamentos devidos pelas Fazendas Públicas Federal, Estaduais, Distrital e Municipais, em virtude de sentença judiciária, far-se-ão exclusivamente na ordem cronológica de apresentação dos precatórios e à conta dos créditos respectivos, proibida a designação de casos ou de pessoas nas dotações orçamentárias e nos créditos adicionais abertos para este fim"108.

Do dispositivo acima transcrito, depreende-se que foi mantida a antiga fórmula já contida na ordem constitucional precedente de que o pagamento de dívida da Fazenda Pública decorrente de decisão judicial seja realizado por precatório, em ordem cronológica, seguindo prévia dotação orçamentária ou nos limites dos créditos adicionais abertos para essa finalidade.

De acordo com o artigo 100, $\S 5^{\circ}$ da Constituição da República, é obrigatória a inclusão no orçamento das entidades de direito público de verba necessária ao pagamento dos precatórios judiciários apresentados até $1^{\circ}$ de julho de cada ano, de modo a possibilitar a sua quitação até o final do exercício seguinte, quando terão seus valores atualizados monetariamente ${ }^{109}$.

Assim, os precatórios apresentados após $1^{\circ}$ de julho de cada ano não serão quitados no exercício financeiro seguinte, ficando para o exercício financeiro subsequente.

Veja-se o seguinte exemplo: apresentado um precatório no dia 30 de agosto de 2012, depois, portanto, de $1^{\mathrm{o}}$ de julho de 2012, este precatório não será pago no final do exercício de 2013, mas tão somente no final do exercício de 2014.

108 Nos termos do artigo 97, caput do Ato das Disposições Constitucionais Transitórias, com a redação dada pela Emenda Constitucional $n^{\circ} 62 / 2009$, a sistemática de pagamento de precatórios prevista na parte permanente da Constituição da República não aplicável aos Estados, ao Distrito Federal e aos Municípios que, na data de publicação Emenda Constitucional $n^{\circ} 62 / 2009$, estejam em mora na quitação de precatórios vencidos, relativos às suas administrações direta e indireta, inclusive os emitidos durante o período de vigência do regime especial por ela instituído. Excetuam-se do regime especial, aplicando-lhes de imediato a regra do artigo 100, caput da Constituição da República: os créditos cujos titulares tenham 60 (sessenta nos ou mais) ou sejam portadores de doenças graves (artigo 100, $\S 2^{\circ}$ da Constituição da República) e as obrigações definidas como de pequeno valor (artigo 100, $\S 3^{\circ}$ da Constituição Federal). Sobre essa postergação de vigência, interessante a observação de Fernando Facury Scaff: "Tal diferimento das regras permanentes é, para dizer o mínimo, um excrescência, uma inversão de valores constitucionais, além de má técnica normativa ao inverter o sentido da disposição transitória". (SCAFF. Fernando Facury. O uso de precatórios para pagamento de tributos após a EC 62. Revista Dialética de Direito Tributário. São Paulo, n. 175, abr. 2010. p. 93).

109 O artigo 100, § 12 da Constituição da República determina que a partir da promulgação da emenda constitucional n 62/2009 “a atualização de valores de requisitórios, após sua expedição, até o efetivo pagamento, independentemente de sua natureza, será feita pelo índice oficial de remuneração básica da caderneta de poupança, e, para fins de compensação da mora, incidirão juros simples no mesmo percentual de juros incidentes sobre a caderneta de poupança, ficando excluída a incidência de juros compensatórios". 
A regra de inclusão de verba específica no orçamento para o pagamento de precatório garante que a dívida decorrente de decisão judicial contrária à Fazenda Pública seja quitada sem abalo ao orçamento do ente público, pois para a despesa de precatório haverá dotação orçamentária específica.

Seguindo o entendimento manifestado pelo Supremo Tribunal Federal, consubstanciado na súmula vinculante $\mathrm{n}^{\circ} 17^{110}$, durante o período correspondente à apresentação do precatório para inclusão no orçamento do exercício seguinte, até o seu efetivo pagamento, prazo constitucionalmente previsto para o seu regular pagamento, não incidem juros de mora sobre os precatórios.

Serão também pagos por meio de precatórios os débitos de natureza alimentícia ${ }^{111}$, os quais compreendem, nos termos do artigo $100, \S 1^{\circ}$ da Constituição da República ${ }^{112}$, os decorrentes de salários, vencimentos, proventos, pensões e suas complementações, benefícios previdenciários e indenizações por morte ou por invalidez, fundadas em responsabilidade civil, em virtude de sentença judicial transitada em julgado ${ }^{113}$.

Os precatórios de natureza alimentícia serão pagos com preferência sobre todos os demais débitos, exceto sobre os débitos de natureza alimentícia cujos titulares tenham 60 (sessenta) anos de idade ou mais na data de expedição do precatório, ou daqueles que sejam portadores de doença grave ${ }^{114}$, definida em da lei ${ }^{115}$, que terão os seus créditos

${ }^{110}$ Súmula vinculante $n^{\circ} 17$ : "Durante o período previsto no parágrafo $1^{\circ}$ do artigo 100 da Constituição, não incidem juros de mora sobre os precatórios que nele sejam pagos". O artigo $100, \S 1^{\circ}$ referido na súmula vinculante corresponde ao atual artigo $100, \S 5^{\circ}$ da Constituição da República.

111 Segundo o entendimento do Supremo Tribunal Federal: "os honorários advocatícios incluídos na condenação pertencem ao advogado e possuem natureza alimentícia. A satisfação pela Fazenda Pública se dá por precatório, observada ordem especial restrita aos créditos de igual natureza". (RE 415950 AgR, Relator Ministro Ayres Britto, Segunda Turma, DJe-162 DIVULG 23-08-2011). Na mesma linha, foi a decisão proferida nos autos do recurso extraordinário n 470.407-DF, Relator Ministro Marco Aurélio, Primeira Turma, DJU 10-10-2006.

$112 \mathrm{O}$ atual artigo $100, \S 1^{\circ}$ da Constituição Federal manteve a definição dos precatórios alimentares que foi introduzida pela Emenda Constitucional n 30, de 13 de setembro de 2000.

113 Aqui uma importante mudança promovida pela Emenda Constitucional n ${ }^{\circ}$ 62/2009, pois o artigo 100 , caput, da Constituição de 1988, na sua redação original, continha ambígua previsão de que os créditos de natureza alimentícia seriam exceção ao pagamento seguindo a ordem cronológica de apresentação dos precatórios. Sobre esse tema, o Supremo Tribunal Federal sumulou o entendimento de que "A exceção prevista no art. 100, "caput", da constituição, em favor dos créditos de natureza alimentícia, não dispensa A expedição de precatório, limitando-se a isentá-los da observância da ordem cronológica dos precatórios decorrentes de condenações de outra natureza" (Súmula 665, DJ de 9/10/2003, p. 3). Essa era a linha que seguia o Superior Tribunal de Justiça, conforme súmula 144 que determina que "Os créditos de natureza alimentícia gozam de preferência, desvinculados os precatórios da ordem cronológica dos créditos de natureza diversa". Assim, existiam duas classes de credores, uma dos detentores de precatórios alimentares, preferencial e outra dos credores comuns.

${ }^{114}$ Araken de Assis observa que apesar de o dispositivo aludir tão só a doença grave, abrangeria as "moléstias contagiosas e incuráveis, que se subentendem 'graves' para esse efeito". (ASSIS, Araken. Manual da Execução. 14. ed. rev. atual. ampl. São Paulo: RT, 2012. p. 1096). 
adimplidos com preferência sobre todos os demais débitos, até o valor equivalente ao triplo do fixado em lei para os fins de determinação das obrigações de pequeno valor, sendo admitido o fracionamento para essa finalidade, hipótese em que o restante será pago na ordem cronológica de apresentação do precatório (artigo 100, $\S 2^{\circ}$ da Constituição Federal).

Vê-se, portanto, que por razões humanitárias foi criada uma hipótese prioritária de recebimento dos precatórios, que se sobrepõe até mesmo à preferência dos créditos de natureza alimentar, estando, porém, os valores a serem recebidos preferencialmente pelos idosos e enfermos graves limitados ao triplo do valor máximo ao fixado em lei pelos entes políticos para o pagamento das obrigações de pequeno valor.

As obrigações de pequeno valor devidas pelas Fazendas Públicas em virtude de sentença judicial transitada em julgado não estão sujeitas à sistemática dos precatórios ${ }^{116}$, motivo pelo qual serão estudadas em tópico próprio, que abaixo será desenvolvido, adiantando-se, por oportuno, que poderão ser fixados como sendo obrigações de pequeno valor, desde que por lei própria, distintos valores para os diversos entes federados, segundo as diferentes capacidades econômicas, respeitado o valor mínimo igual correspondente ao valor do maior benefício do regime geral de previdência social, conforme determina o artigo 100, $\S 4^{\circ}$ da Constituição Federal. E, enquanto não estabelecidos tais valores pelos entes federados, aplica-se a regra do artigo 87 do Ato das Disposições Constitucionais Transitórias, que fixa em as obrigações de pequeno valor em quarenta salários-mínimos, para a Fazenda dos Estados e do Distrito Federal e em trinta salários-mínimos, perante a Fazenda dos Municípios.

Com suporte nessas considerações, Marcus Abraham ${ }^{117}$ aponta a existência de três métodos de pagamento da dívida pública decorrente de decisão judicial contrária à Fazenda Pública, quais sejam: os precatórios comuns, os precatórios alimentares e os créditos de pequeno valor, assim expondo:

\footnotetext{
115 Nos termos do artigo 13 artigo da Resolução n ${ }^{\circ}$ 115/2010 do Conselho Nacional de Justiça (com as alterações promovidas pela Resolução CNJ n $\left.{ }^{\circ} 123 / 10\right)$, são consideradas doenças graves as moléstias indicadas no inciso XIV do artigo $6^{\circ}$ da Lei ${ }^{\circ} 7.713 / 88$ (com a redação dada pela Lei $\left.n^{\circ} 11.052 / 04\right)$. Esse rol de doenças graves é também observado pelo Tribunal de Justiça de São Paulo (Ordem de serviço ${ }^{\circ}$ 3/2010, DEPRE, item II, 10.1).

${ }^{116}$ Artigo 100, $\S 3^{\circ}$ da Constituição da República.

117 ABRAHAM, Marcus. Reflexões sobre a EC 62/2009: a compensação de precatórios com créditos da Fazenda Pública. Revista tributária e de finanças públicas. São Paulo: RT, n. 94, set.-out. 2010. p. 230.
} 


\begin{abstract}
Além dos créditos comuns que são pagos regularmente através da metodologia da expedição dos precatórios, existem outras duas espécies de pagamentos decorrentes de condenação judicial da Fazenda Pública, que possuem especificidades próprias nas regras dos precatórios. São os créditos de natureza alimentar e os créditos de pequeno valor. Os primeiros são igualmente pagos por precatórios, mas antes dos demais precatórios comuns, e os segundos ficam fora da metodologia de pagamento por precatórios.

Portanto, dentro do regime de pagamento de condenações judiciais da Fazenda Pública que a Constituição disciplina, identificamos três métodos: a) os precatórios comuns, pagos segundo as regras ora analisadas; b) os precatórios alimentares, que preferem aos comuns; c) os créditos de pequeno valor, que não se submetem às regras dos precatórios.
\end{abstract}

Já para Araken de $\operatorname{Assis}^{118}$, os créditos na execução contra a Fazenda Pública dividem-se em cinco classes de pagamento, confira-se:

\begin{abstract}
À luz dessas considerações, há cinco classes de créditos na execução contra a Fazenda Pública: (a) créditos de pessoas idosas e doentes, até o triplo do crédito de pequeno valor, consoante a definição própria de cada pessoa jurídica de direito público (art. 100, $\S 2^{\circ}, \mathrm{c} / \mathrm{c} \S 3^{\circ}$, e art. 97, $\S 12$, I e II, do art. 97 do $\mathrm{ADCT}$ ); (b) créditos alimentares de pequeno valor; (c) créditos comuns de pequeno valor; (d) créditos alimentares de maior valor; (e) créditos comuns de maior valor, parcelados ou não. Em relação aos créditos alimentares e comuns de maior valor, além disso, no regime excepcional do art. 97 do ADCT, há uma preferência específica, beneficiando credores que hajam completado sessenta anos na data da promulgação da EC 62/2009, segundo $\S 18$ daquele dispositivo.
\end{abstract}

Não obstante ainda não se tenha adentrado à análise da parte transitória da Constituição da República, o que se fará a seguir, a classificação dos créditos decorrentes de ações judiciais propostas contra a Fazenda Pública em três classes, como proposto por Marcus Abraham, mostra-se mais adequada diante do texto constitucional vigente.

Isso porque os créditos que preferem os alimentares, de titularidade de idosos e para portadores de doenças graves, não irão compor uma lista específica de pagamento, como se dá com os precatórios alimentares, os comuns e as obrigações de pequeno valor.

Ao contrário, os pagamentos feitos aos idosos e portadores de doenças graves, a par de serem limitados no valor, serão sempre esporádicos, casuísticos, não havendo que se falar em uma classe própria. Com efeito, estes créditos serão alimentares ou comuns, apenas adiantando-se parte de seu pagamento por questões humanitárias.

Do mesmo modo, não há razão para se diferençar obrigações de pequeno valor pela natureza do crédito, pois, sendo de pequeno valor, o crédito de natureza alimentar ou comum será pago da mesma maneira, bem como estará ele fora da sistemática dos precatórios.

${ }^{118}$ ASSIS, Araken. Manual da Execução. 14. ed. rev. atual. ampl. São Paulo: RT, 2012. p. 1096. 
Posto isso, importante observar que é vedada expedição de precatórios comuns e alimentares $^{119}$, bem como de requisições para pagamento de obrigações de pequeno valor $^{120}$, antes do trânsito em julgado da decisão que condenar a Fazenda Pública.

Anote-se, ainda, que o transito em julgado exigido pelo artigo 100 da Constituição da República refere-se à última decisão proferida no processo, que na maioria dos casos será a decisão prolatada no processo de execução intentada contra a Fazenda Pública.

Por essa razão, eventuais embargos à execução ou recurso de apelação interposto pela Fazenda Pública serão recebidos necessariamente no efeito suspensivo.

De outro lado, caso não sejam opostos embargos à execução ${ }^{121}$, ou na hipótese de serem estes apenas parciais, permite-se seja expedida requisição de pagamento, na ordem de apresentação do precatório, da parte incontroversa, não implicando tal situação o fracionamento do precatório, que é vedado pelo artigo $100, \S 8^{\circ}$ da Constituição Federal $^{122}$.

Nesse sentido é a sedimentada jurisprudência do Superior Tribunal de Justiça, que considera que "é possível a expedição de precatório relativamente à parte incontroversa da dívida quando se tratar de embargos parciais à execução opostos pela Fazenda Pública ${ }^{123}$.

Essa também é a linha seguida por Fredie Didier Jr., Leonardo J. C. Cunha, Paula Sarno Braga e Rafael Oliveira ${ }^{124}$, que assim lecionam:

\begin{abstract}
Ora, se o precatório somente pode ser expedido quando já definitivo o valor, não havendo mais discussão a seu respeito - o que se pode comprovar por certidão de trânsito em julgado dos embargos à execução -, é evidente que tais embargos devem, necessariamente, ser recebidos com efeito suspensivo.
\end{abstract}

${ }^{119}$ Artigo $100, \S \S 1^{\circ}$ e $5^{\circ}$ da Constituição Federal.

${ }^{120}$ Artigo $100, \S 3^{\circ}$ da Constituição Federal.

${ }^{121}$ Discute-se o prazo para a oposição de embargos à execução pela Fazenda Pública, tendo em vista a ampliação dos prazos dos artigos 730 do Código de Processo Civil e do artigo 884 da Consolidação das Leis do Trabalho pela Medida Provisória $\mathrm{n}^{\circ}$ 2.180-35/2001, que acrescentou o artigo $1^{\circ}$-B da Lei federal $\mathrm{n}^{\circ}$ 9.494/97. Contudo, deve-se aplicar o prazo de 30 dias por força da medida cautelar deferida pelo Supremo Tribunal Federal, nos autos da Ação Declaratória de Constitucionalidade $\mathrm{n}^{\circ} 11$, que determinou a suspensão de todos os processos em que se discuta a constitucionalidade do artigo $1^{\circ} \mathrm{B}$ da Lei $\mathrm{n}^{\circ}$ 9.494/97 (ADC 11 MC, Relator Ministro Cezar Peluso, Tribunal Pleno, DJ 29-06-2007).

${ }^{122}$ Dispõe o artigo $100, \S 8^{\circ}$ da Constituição Federal: "É vedada a expedição de precatórios complementares ou suplementares de valor pago, bem como o fracionamento, repartição ou quebra do valor da execução para fins de enquadramento de parcela do total ao que dispõe o $\S 3^{\circ}$ deste artigo".

123 EREsp 638.597/RS, Rel. Ministro Francisco Falcão, Corte Especial, julgado em 01/08/2011, DJe 29/08/2011. Na mesma direção: EREsp n ${ }^{\circ}$ 759.405/PR, Corte Especial, Rel. Min. Eliana Calmon, DJe de 21/08/2008, AgRg nos EREsp n ${ }^{\circ}$ 692.044/RS, Corte Especial, Rel. Min. Arnaldo Esteves Lima, DJe de 21/08/2008, EREsp $n^{\circ}$ 658.542/SC, Corte Especial, Rel. Min. Francisco Peçanha Martins, DJ de 26/02/2007, EREsp n ${ }^{\circ}$ 668.909/RS, Corte Especial, Rel. Min. Hamilton Carvalhido, DJ de 21/08/2006. No mesmo sentido, no Supremo Tribunal Federal: RE 458110, Relator Ministro Marco Aurélio, Primeira Turma, julgado em 13/06/2006, DJ 29-09-2006, Informativo 433.

${ }^{124}$ DIDIER JUNIOR, Fredie; CUNHA, Leonardo José Carneiro da; BRAGA, Paula Sarno; OLIVEIRA, Rafael. Curso de direito processual civil: execução. 4. ed. v. 5. Salvador: Jus Podium, 2012 p. 727. 
Quando os embargos forem parciais, a execução, nos termos do $\S 3^{\circ}$ do art. 739$\mathrm{A}$ do $\mathrm{CPC}$, prosseguirá quanto à parte não embargada. Tal regra aplica-se aos embargos opostos pela Fazenda Pública. Nesse caso, a execução deve prosseguir relativamente ao valor equivalente à parte incontroversa, expedindo-se, quanto a essa parte, o precatório. Em tal situação, não está havendo o fracionamento vedado no parágrafo $8^{\circ}$ do art. 100 da Constituição Federal, eis que não se trata de intenção do exeqüente de repartir o valor para receber uma parte por requisição de pequeno valor e a outra, por precatório.

Disciplina o artigo 100, $\S 6^{\circ}$ da Constituição Federal que as dotações orçamentárias e os créditos abertos para a quitação dos precatórios serão consignados diretamente ao Poder Judiciário, cabendo ao Presidente do Tribunal que proferir a decisão exequenda determinar o pagamento integral e autorizar, a requerimento do credor e exclusivamente para os casos de preterimento de seu direito de precedência ou de não alocação orçamentária do valor necessário à satisfação do seu débito, o sequestro da quantia respectiva.

O sequestro é uma exceção constitucional à impossibilidade de constrição de bens públicos $^{125}$, caracterizando-se como medida de natureza satisfativa, consistente na efetiva entrega da quantia em dinheiro aquele que teve seu direito preterido. Por isso, tal medida muito mais se assemelharia ao arresto ${ }^{126}$ que ao sequestro.

Nesse sentido lecionam Fredie Didier Jr., Leonardo J. C. Cunha, Paula Sarno Braga e Rafael Oliveira ${ }^{127}$ :

O referido seqüestro nada mais é do que um arresto, sendo imprópria a designação de seqüestro, pois serve à execução de crédito pecuniário. Tal arresto, contudo, não ostenta a natureza de medida cautelar, consistindo numa medida satisfativa, de natureza executiva, destinada a entregar a quantia apreendida ao credor preterido em sua preferência.

Note-se que a Emenda Constitucional no 62/2009 alargou as situações em que se autoriza o sequestro de quantia para fazer frente ao pagamento de precatórios.

${ }^{125}$ Cf. MOREIRA, José Carlos Barbosa . O novo processo civil brasileiro: exposição sistemática do procedimento. 27. ed. 2. tir. Rio de Janeiro: Forense, 2009. p. 272.

${ }^{126}$ Segundo doutrina de Luiz Guilherme Marinoni e Daniel Mitidiero o aresto é "uma medida cautelar que visa resguardar temporariamente de um perigo de dano o direito à tutela ressarcitória. Protege-se a aparência de um direito de crédito. Tem por desiderato sujeitar o bem arrestado à finalidade executiva. Pouco interessa se a tutelar ressarcitória acautelada é tutela específica ou tutela pelo equivalente monetário. Para que se tenha lugar o arresto, basta que se proteja o direito à tutela ressarcitória - o direito à realização do direito ao crédito mediante a possibilidade de fruição do resultado do binômio condenação- execução forçada". (MARINONI, Luiz Guilherme; MITIDIERO, Daniel. Código de processo civil comentado artigo por artigo. 2 ed. São Paulo: Revista dos Tribunais, 2010. p. 773).

127 DIDIER JUNIOR, Fredie; CUNHA, Leonardo José Carneiro da; BRAGA, Paula Sarno; OLIVEIRA, Rafael. Curso de direito processual civil: execução. 4. ed. v. 5. Salvador: Jus Podium, 2012 p. 738. 
No regime anterior, o sequestro estava restrito aos casos de quebra na ordem cronológica de pagamento dos precatórios ${ }^{128}$, situações em que um credor era preterido no seu direito ao recebimento do precatório.

Atualmente, como visto, além da hipótese de preterição, o sequestro é autorizado também para os casos em que não há alocação de recursos suficientes no orçamento para o pagamento dos precatórios apresentados ${ }^{129}$.

Além do sequestro, a Constituição Federal prevê hipóteses de intervenção da União nos Estados e Distrito Federal (artigo 34 da Constituição Federal) e dos Estados nos Municípios (artigo 35 da Constituição Federal) e da União nos território Federais (artigo 36, da Constituição Federal), nos casos de injustificada inadimplência de precatórios ${ }^{130}$.

O instituto constitucional da intervenção federal fundamentada na inobservância de cumprimento de ordem judicial que determina o pagamento de um precatório não é observado na prática, pois o Supremo Tribunal Federal considera que a alegação de insuficiência de recursos e a ausência conduta dolosa e deliberada com finalidade de não pagamento pelo ente federado ${ }^{131}$ impedem a adoção da drástica medida interventiva ${ }^{132}$.

Esse entendimento levou o professor Araken de Assis ${ }^{133}$ a considerar que a intervenção está atualmente desmoralizada, principalmente se considerado o caso específico do Estado de São Paulo, assim pontua o citado professor:

No entanto, a descomunal dívida pública de alguns Estados, provocando a flagrante impossibilidade de solver a dívida consolidada sem prejuízo da continuidade da prestação de serviços públicos, desmoralizou a sanção constitucional. O STF reconheceu, no caso sintomático do Estado de São Paulo,

${ }^{128}$ Antes da emenda Constitucional $n^{\circ} 62 / 2009$, a matéria era tratada pelo artigo $100, \S 2^{\circ}$, com a redação dada pela emenda Constitucional $n^{\circ} 30 / 2000$, que assim dispunha: " $\$ 2^{\circ}$ As dotações orçamentárias e os créditos abertos serão consignados diretamente ao Poder Judiciário, cabendo ao Presidente do Tribunal que proferir a decisão exeqüenda determinar o pagamento segundo as possibilidades do depósito, e autorizar, a requerimento do credor, e exclusivamente para o caso de preterimento de seu direito de precedência, o seqüestro da quantia necessária à satisfação do débito."

129 O Artigo 78, $\S 4^{\circ}$ do ADCT, introduzido pela Emenda Constitucional $n^{\circ} 30 / 2000$, continha previsão semelhante, confira-se: "art. 78. [...] § $4^{\circ}$ O Presidente do Tribunal competente deverá, vencido o prazo ou em caso de omissão no orçamento, ou preterição ao direito de precedência, a requerimento do credor, requisitar ou determinar o seqüestro de recursos financeiros da entidade executada, suficientes à satisfação da prestação.

130 Segundo Fredie Didier Jr., Leonardo J. C. Cunha, Paula Sarno Braga e Rafael Oliveira a intervenção também seria possível nos casos de pagamento parcial dos precatórios. DIDIER JUNIOR, Fredie; CUNHA, Leonardo José Carneiro da; BRAGA, Paula Sarno; OLIVEIRA, Rafael. Curso de direito processual civil: execução. 4. ed. v. 5. Salvador: Jus Podium, 2012 p 740).

${ }^{131}$ Cf. MORAES, Alexandre de. Direito constitucional. 28. ed. São Paulo: Atlas, 2012. p. 609.

132 Nessa linha são os seguintes julgados: IF 5101, Relator Min. Cezar Peluso (Presidente), Tribunal Pleno, acórdão eletrônico DJe- 05-09-2012; IF 506 AgR, Relator Min. Maurício Corrêa, Tribunal Pleno, DJ 2506-2004; e IF 298, Relator Min. Marco Aurélio, Relator(a) p/ Acórdão Min. Gilmar Mendes, Tribunal Pleno, DJ 27-02-2004.

133 ASSIS, Araken de. Manual da Execução.14. ed. rev. atual. ampl. São Paulo: RT, 2012. p. 1116. 
a falta de atuação dolosa e deliberada de seus agentes políticos, retendo as verbas orçamentárias, e negou o pedido de intervenção federal.

A Constituição Federal estabelece ainda que o Presidente do Tribunal competente que, por ato comissivo ou omissivo, retardar ou tentar frustrar a liquidação regular de precatórios incorrerá em crime de responsabilidade e responderá, também, perante o Conselho Nacional de Justiça.

No que se refere à cessão de créditos de precatórios, a Constituição da República prevê que o credor poderá cedê-los, total ou parcialmente, independentemente da concordância do devedor, não se aplicando ao cessionário, contudo, as preferências, de caráter pessoal, asseguradas ao idoso e ao portador de doença grave, bem como o recebimento do valor, cedido parcialmente, pela sistemática das obrigações de pequeno valor. A cessão de precatórios somente produzirá efeitos após comunicação, por meio de petição protocolizada, ao tribunal de origem e à entidade devedora.

Consta também do regramento constitucional dos precatórios, a previsão de que a União, a seu critério exclusivo e na forma de lei, poderá assumir débitos, oriundos de precatórios, de Estados, Distrito Federal e Municípios, refinanciando-os diretamente.

Permite ainda a Constituição da República que seja editada lei da entidade federativa devedora, facultando a entrega de créditos em precatórios para compra de imóveis públicos do respectivo ente federado.

Até aqui, viu-se, em resumo, que as Fazendas Públicas condenadas judicialmente devem realizar o pagamento dessas dívidas por meio de precatório, o qual será quitado seguindo a ordem cronológica de apresentação, organizada de acordo com a natureza da dívida, com a ressalva do direito de preferência dos credores idosos e portadores de doenças graves. Ademais, constatou-se que a regra do pagamento por meio de precatórios não é aplicável aos créditos definidos como de pequeno valor.

Demais disso, pode-se inferir que tanto os precatórios, como os requisitórios de pequeno valor, somente poderão ser expedidos após o trânsito em julgado da decisão judicial, quando for definitivo o valor da dívida, admitindo-se, excepcionalmente, caso sejam opostos embargos à execução apenas parcial, a expedição de precatório de parte incontroversa.

Depreendeu-se também que as dotações orçamentárias e os créditos abertos para a quitação dos precatórios serão consignados diretamente ao Poder Judiciário que administrará o pagamento dos precatórios, que poderá a requerimento do credor, nos casos 
de preterimento de seu direito de precedência ou de não alocação orçamentária do valor necessário à satisfação do seu débito, autorizar o sequestro da quantia respectiva.

Há, também, a possibilidade de se determinar a intervenção nos entes federados, na hipótese de ser intencional e injustificado o não pagamento de precatórios.

De outro lado, poderá responder o Presidente de Tribunal por crime de responsabilidade caso sua conduta, ou sua omissão, atrase ou impeça o regular pagamento de um precatório, respondendo, ainda, perante o Conselho Nacional de Justiça.

Destaca-se que, dado o escopo do presente estudo, a compensação disciplinada pelo artigo $100, \S 9^{\circ}$ e 10 da Constituição Federal será analisada com mais detalhes adiante.

Do mesmo modo, será tratado com mais vagar o regime especial para pagamento de precatórios vencidos, inserto no artigo 97 do ADCT, também referido pelo artigo 100, $§ 15$ da Constituição Federal.

Feitas tais considerações, passa-se à parte transitória da Constituição da República, onde se concentra a quase totalidade das discussões envolvendo a utilização de precatórios como forma de extinção de créditos tributários.

\subsubsection{O pagamento do estoque de precatórios regulamentado pelo Ato das Disposições Constitucionais Transitórias - ADCT}

Na época em que promulgada a Constituição da República de 1988, o estoque da dívida pública representada por precatórios já era um grave problema para a Administração Pública, a ponto de a própria Assembleia Constituinte instituir o primeiro parcelamento de precatórios, em oito prestações anuais, o qual foi alcunhado de primeira moratória ou de primeiro "calote público".

Referido parcelamento foi previsto no artigo 33 do Ato das Disposições Constitucionais Transitórias, que assim dispõe:

Art. 33. Ressalvados os créditos de natureza alimentar, o valor dos precatórios judiciais pendentes de pagamento na data da promulgação da Constituição, incluído o remanescente de juros e correção monetária, poderá ser pago em moeda corrente, com atualização, em prestações anuais, iguais e sucessivas, no 
prazo máximo de oito anos, a partir de $1^{\circ}$ de julho de 1989 , por decisão editada pelo Poder Executivo até cento e oitenta dias da promulgação da Constituição ${ }^{134}$.

Todavia, o parcelamento do artigo 33 do ADCT não foi suficiente para estancar o crescimento da dívida de precatórios, notadamente em razão da hiperinflação que atingia o país, que fora combinada com a frequente execução de planos econômicos que não tiveram sucesso $^{135}$, além de outros fatores como, por exemplo, o endividamento público externo.

Assim, ao contrário do que se esperava, não foi possível acabar com o estoque de precatórios, que, aliás, aumentou muito nesse período.

Para solucionar esse novo quadro insustentável da dívida pública representada por precatórios, que era uma realidade para quase todos os entes federados, com destaque para os Estados do Sul e Sudeste e, dentre eles, especialmente o Estado de São Paulo, pensou-se em um novo parcelamento.

Esse parcelamento foi levado a efeito pelo artigo 78 do Ato das Disposições Constitucionais Transitórias, inserido pela emenda Constitucional n 30 de 2000, in verbis:

\begin{abstract}
Art. 78. Ressalvados os créditos definidos em lei como de pequeno valor, os de natureza alimentícia, os de que trata o art. 33 deste Ato das Disposições Constitucionais Transitórias e suas complementações e os que já tiverem os seus respectivos recursos liberados ou depositados em juízo, os precatórios pendentes na data de promulgação desta Emenda e os que decorram de ações iniciais ajuizadas até 31 de dezembro de 1999 serão liquidados pelo seu valor real, em moeda corrente, acrescido de juros legais, em prestações anuais, iguais e sucessivas, no prazo máximo de dez anos, permitida a cessão dos créditos.
\end{abstract}

$\S 1^{\circ}$ É permitida a decomposição de parcelas, a critério do credor.

$\S 2^{\circ}$ As prestações anuais a que se refere o caput deste artigo terão, se não liquidadas até o final do exercício a que se referem, poder liberatório do pagamento de tributos da entidade devedora.

$\S 3^{\circ} \mathrm{O}$ prazo referido no caput deste artigo fica reduzido para dois anos, nos casos de precatórios judiciais originários de desapropriação de imóvel residencial do credor, desde que comprovadamente único à época da imissão na posse.

$\S 4^{\circ} \mathrm{O}$ Presidente do Tribunal competente deverá, vencido o prazo ou em caso de omissão no orçamento, ou preterição ao direito de precedência, a requerimento do credor, requisitar ou determinar o seqüestro de recursos financeiros da entidade executada, suficientes à satisfação da prestação

${ }^{134}$ Note-se que esse parcelamento não se aplicava aos créditos de natureza alimentar, por expressa previsão constitucional: "ressalvados os créditos de natureza alimentar". Tal restrição, repetida no parcelamento instituído pelo artigo 78 do ADCT ensejou inúmeras discussões judiciais, conforme exposto a seguir.

${ }^{135}$ O Brasil experimentou sucessivos planos de estabilização da economia entre as décadas de 80 e 90 , em razão da insustentável inflação de até $363 \%$ ao ano que castigava o país. De início foi implementado o Plano Cruzado (1986), que procurou estabilizar a economia por meio da desindexação, alterando as regras de correção monetária vigentes, além de estabelecer o congelamento de preços e salários. Em seguida vieram o Plano Bresser (1987) e o Plano Verão (1989). Depois disso, o Plano Collor I (1990), famoso pelo "confisco" de recursos disponíveis em cadernetas de poupança e contas-corrente, e o Plano Collor II (1991). Contudo, a efetiva estabilização da economia foi conseguida apenas em 1994, com o Plano Real. 
Esse novo parcelamento do artigo 78 do $\mathrm{ADCT}^{136}$ provocou o surgimento das teses que constituem parte significativa deste estudo, tais como a alegação de inconstitucionalidade da exceção imposta aos precatórios alimentares e aos precatórios que estavam abrangidos pelo parcelamento do artigo 33 do ADCT, o eventual direito à compensação independente de lei, em virtude da previsão de permissão de cessão de créditos de precatórios combinada com a possibilidade de se atribuir poder liberatório do pagamento de tributos da entidade devedora às parcelas deste parcelamento que não adimplidas até o final do exercício financeiro a que se referiam ${ }^{137}$. Essas questões serão melhor analisadas adiante.

É importante ressaltar, no entanto, que por ter sido esse novo parcelamento instituído por uma emenda constitucional, diferente do que ocorreu com o parcelamento do artigo 33 do ADCT, que constava da redação original da Constituição, diversas ações foram ajuizadas objetivando o reconhecimento de sua inconstitucionalidade.

Dessas ações, merecem especial atenção as Ações Diretas de Inconstitucionalidade $\mathrm{n}^{\circ} \mathrm{s} 2356$ e 2362, pois nestas ações foi deferida pelo Supremo Tribunal Federal medida cautelar para suspender o artigo $2^{\circ}$ da Emenda Constitucional $n^{\circ} 30 / 2000$, que inseriu o artigo 78 no ADCT. A decisão está assim ementada:

MEDIDA CAUTELAR EM AÇÃO DIRETA DE
INCONSTITUCIONALIDADE. ART. $2^{\circ}$ DA EMENDA CONSTITUCIONAL
$\mathrm{N}^{\circ}$ 30, DE 13 DE SETEMBRO DE 2000, QUE ACRESCENTOU O ART. 78
AO ATO DAS DISPOSIÇÕES CONSTITUCIONAIS TRANSITÓRIAS.
PARCELAMENTO DA LIQUIDAÇÃO DE PRECATÓRIOS PELA
FAZENDA PÚBLICA.
1. O precatório de que trata o artigo 100 da Constituição consiste em
prerrogativa processual do Poder Público. Possibilidade de pagar os seus débitos
não à vista, mas num prazo que se estende até dezoito meses. Prerrogativa
compensada, no entanto, pelo rigor dispensado aos responsáveis pelo
cumprimento das ordens judiciais, cujo desrespeito constitui, primeiro,
pressuposto de intervenção federal (inciso VI do art. 34 e inciso V do art. 35, da
CF) e, segundo, crime de responsabilidade (inciso VII do art. 85 da CF).
2. O sistema de precatórios é garantia constitucional do cumprimento de decisão
judicial contra a Fazenda Pública, que se define em regras de natureza processual

${ }^{136}$ A Emenda Constitucional no 37 de 12 de junho de 2002, inseriu o artigo 87 no ADCT, estabelecendo os critérios para a determinação de uma obrigação de pequeno valor nos Estados, Distrito Federal e Municípios. A referida emenda constitucional também determinou a inclusão do artigo 86 ao ADCT, que excluiu do parcelamento do artigo 78, também do ADCT, as obrigações de pequeno valor que se encontravam pendentes de pagamento.

137 O Estado de São Paulo, assim como outros entes da federação, possui legislação específica regulamentando o artigo 78 do ADCT.Trata-se da Lei Estadual $n^{\circ} 11.377$ de 14 de abril de 2003, que em seu artigo $8^{\circ}$ determina que "O efeito liberatório do pagamento de tributos estaduais, que venha a ser atribuído às prestações não liquidadas, nos termos do $\S 2^{\circ}$ do artigo 78 do Ato das Disposições Constitucionais Transitórias, dependerá de requerimento expresso do credor ao juízo da execução, no processo de origem, e produzirá efeitos a partir da intimação da entidade devedora pela Presidência do Tribunal que houver requisitado o pagamento". 
conducentes à efetividade da sentença condenatória trânsita em julgado por quantia certa contra entidades de direito público. Além de homenagear o direito de propriedade (inciso XXII do art. $5^{\circ}$ da CF), prestigia o acesso à jurisdição e a coisa julgada (incisos XXXV e XXXVI do art. $5^{\circ}$ da CF).

3. A eficácia das regras jurídicas produzidas pelo poder constituinte (redundantemente chamado de "originário") não está sujeita a nenhuma limitação normativa, seja de ordem material, seja formal, porque provém do exercício de um poder de fato ou suprapositivo. Já as normas produzidas pelo poder reformador, essas têm sua validez e eficácia condicionadas à legitimação que recebam da ordem constitucional. Daí a necessária obediência das emendas constitucionais às chamadas cláusulas pétreas.

4. $\mathrm{O}$ art. 78 do Ato das Disposições Constitucionais Transitórias, acrescentado pelo art. $2^{\circ}$ da Emenda Constitucional n ${ }^{\circ} 30 / 2000$, ao admitir a liquidação "em prestações anuais, iguais e sucessivas, no prazo máximo de dez anos" dos "precatórios pendentes na data de promulgação" da emenda, violou o direito adquirido do beneficiário do precatório, o ato jurídico perfeito e a coisa julgada. Atentou ainda contra a independência do Poder Judiciário, cuja autoridade é insuscetível de ser negada, máxime no concernente ao exercício do poder de julgar os litígios que lhe são submetidos e fazer cumpridas as suas decisões, inclusive contra a Fazenda Pública, na forma prevista na Constituição e na lei. Pelo que a alteração constitucional pretendida encontra óbice nos incisos III e IV do $\S 4^{\circ}$ do art. 60 da Constituição, pois afronta "a separação dos Poderes" e "os direitos e garantias individuais".

5. Quanto aos precatórios "que decorram de ações iniciais ajuizadas até 31 de dezembro de 1999”, sua liquidação parcelada não se compatibiliza com o caput do art. $5^{\circ}$ da Constituição Federal. Não respeita o princípio da igualdade a admissão de que um certo número de precatórios, oriundos de ações ajuizadas até 31.12.1999, fique sujeito ao regime especial do art. 78 do ADCT, com o pagamento a ser efetuado em prestações anuais, iguais e sucessivas, no prazo máximo de dez anos, enquanto os demais créditos sejam beneficiados com o tratamento mais favorável do $\S 1^{\circ}$ do art. 100 da Constituição.

6. Medida cautelar deferida para suspender a eficácia do art. $2^{\circ}$ da Emenda Constitucional $n^{\circ} 30 / 2000$, que introduziu o art. 78 no ADCT da Constituição de 1988.

(ADI 2356 MC, Relator Min. Néri da Silveira, Relator p/ Acórdão: Min. Ayres Britto, Tribunal Pleno, julgado em 25/11/2010, DJe 18-05-2011)

Portanto, o artigo 78 do ADCT, atualmente, encontra-se com a sua eficácia suspensa por força da referida medida cautelar ${ }^{138}$.

Não fosse isso, o dispositivo também estaria prejudicado pela edição da Emenda Constitucional $\mathrm{n}^{\mathrm{o}} 62$ de 2009, que estabeleceu uma nova regra de transição para o pagamento do ainda existente e relevante estoque de precatórios, abrangendo todos os precatórios que haviam sido parcelados nos termos do artigo 78 do ADCT.

138 Não obstante a decisão que suspendeu a eficácia o artigo 78 do ADCT, encontram-se pendentes de julgamento no Supremo Tribunal Federal diversas ações envolvendo o citado dispositivo constitucional, como o recurso extraordinário $n^{\circ} 597.092$, em que se reconheceu a existência de repercussão geral no caso que se discute a possibilidade de o ente público optar pela realização do pagamento dos precatórios de maneira integral nos termos do artigo 100 da Constituição ou de forma parcelada, de acordo com o artigo 78 do ADCT, RE 597092 RG, Relator Min. Ricardo Lewandowski, julgado em 05/11/2009, DJe 19-11-2009. Os autos do processo encontram-se conclusos ao Ministro Relator em 04/10/2012. 
Nessa linha vem se consolidando a jurisprudência do Superior Tribunal de Justiça, afirmando que "o art. 97 do ADCT, ao regular, por inteiro, a matéria antes disciplinada no art. 78, § $2^{\circ}$, do ADCT, revogou, tacitamente, esse último dispositivo constitucional"139.

A Emenda Constitucional no 62 de 2009, como já adiantado, alterou tanto a parte permanente da Constituição quanto a transitória no que tange ao regramento dos precatórios.

Na parte transitória, a Emenda Constitucional n ${ }^{\circ}$ 62/2009 acrescentou o artigo 97 ao Ato das Disposições Constitucionais Transitórias, instituindo o regime especial para o pagamento de precatórios vencidos cuja observância é obrigatória ${ }^{140}$ para os Estados, Distrito Federal e Municípios que se encontravam em mora na data de sua promulgação ${ }^{141}$.

Segundo dispõe o artigo 97, $\S 1^{\circ}$ do ADCT, os entes federados em mora com a quitação de precatórios vencidos, tanto da administração direta quanto da indireta, podem optar por uma das duas formas de regime especial para o pagamento de tributos: (i) depósitos mensais, calculados com aplicação de percentuais sobre a receita corrente líquida, ou (ii) pelo depósito anual no prazo máximo de 15 anos, caso em que o percentual a ser depositado corresponderá ao saldo total dos precatórios devidos, acrescido do índice oficial de remuneração básica da caderneta de poupança e de juros simples no mesmo percentual de juros incidentes sobre a caderneta de poupança para fins de compensação da mora, excluída a incidência de juros compensatórios, diminuído das amortizações e dividido pelo número de anos restantes no regime especial de pagamento ${ }^{142}$.

139 AgRg nos EDcl no RMS 35.372/PR, Rel. Ministro Benedito Gonçalves, Primeira Turma, julgado em 20/10/2011, DJe 26/10/2011. Na mesma linha: RMS 31.912/PR, Rel. Ministro Benedito Gonçalves, Primeira Turma, DJe 25/11/2010; RMS 28783/PR, Rel. Ministro Mauro Campbell Marques, Segunda Turma, DJe 18/8/2011; e AgRg no RMS 34.812/PR, Rel. Ministro Herman Benjamin, Segunda Turma, julgado em 20/09/2011, DJe 23/09/2011; AgRg no RMS 28.547/PR, Rel. Ministro Napoleão Nunes Maia Filho, Primeira Turma, julgado em 16/02/2012, DJe 08/03/2012

140 Nesse sentido já decidiu a Primeira Turma do Superior Tribunal de Justiça: “As Fazendas Públicas Federal, Estaduais, Distrital e Municipais estão obrigadas a observarem as novas regras constitucionais trazidas pela EC n. 62/2009, razão pela qual, diante da revogação do art. $78, \S 2^{\circ}$, do ADCT, estão impossibilitadas de pagarem os precatórios de forma contrária à previsão constitucional, caso optem pelo regime especial, como no caso; daí porque prejudicado o mandado de segurança pela superveniência da referida emenda constitucional'. (AgRg nos EDcl no RMS 35.372/PR, Rel. Ministro Benedito Gonçalves, Primeira Turma, julgado em 20/10/2011, DJe 26/10/2011).

141 O artigo 100, § 15 da Constituição determina que: "Sem prejuízo do disposto neste artigo, lei complementar a esta Constituição Federal poderá estabelecer regime especial para pagamento de crédito de precatórios de Estados, Distrito Federal e Municípios, dispondo sobre vinculações à receita corrente líquida e forma e prazo de liquidação". Contudo, enquanto não editada lei complementar a que aludo o artigo $100, \S 15$, é obrigatória a adesão ao regime especial pelos entes federados em mora no pagamento de precatórios vencidos, nos termos do artigo 97 do ADCT.

${ }^{142}$ Nos termos do artigo $4^{\circ}$ da Emenda Constitucional $n^{\circ} 62 / 2009$, o ente federado em mora no pagamento dos precatórios, somente deixará o regime especial do artigo 97 do ADCT para seguir os ditames do artigo 100 da Constituição Federal, se tiver optado pelos depósitos mensais, quando o valor dos 
A primeira opção, de depósitos mensais, é a que traz implicações tributárias, motivo pelo qual a análise do regime especial se concentrará nessa modalidade.

Escolhido o depósito mensal, deve-se notar que os percentuais a serem depositados são estabelecidos de acordo com o valor do estoque de precatórios em relação à receita corrente líquida do respectivo ente federado, ou ainda de acordo com a sua localização geográfica no território nacional.

Para os Estados e para o Distrito Federal, o depósito mensal deverá corresponder a, no mínimo, 1,5\% (um inteiro e cinco décimos por cento), para os Estados das regiões Norte, Nordeste e Centro-Oeste, além do Distrito Federal, ou cujo estoque de precatórios pendentes das suas administrações direta e indireta corresponder a até 35\% (trinta e cinco por cento) do total da receita corrente líquida. Ou de, no mínimo, 2\% (dois por cento), para os Estados das regiões Sul e Sudeste, cujo estoque de precatórios pendentes das suas administrações direta e indireta corresponder a mais de $35 \%$ (trinta e cinco por cento) da receita corrente líquida ${ }^{143}$.

Já para os Municípios, o percentual será de, no mínimo, 1\% (um por cento), para Municípios das regiões Norte, Nordeste e Centro-Oeste, ou cujo estoque de precatórios pendentes das suas administrações direta e indireta corresponder a até 35\% (trinta e cinco por cento) da receita corrente líquida, e de, no mínimo, 1,5\% (um inteiro e cinco décimos por cento), para Municípios das regiões Sul e Sudeste, cujo estoque de precatórios pendentes das suas administrações direta e indireta corresponder a mais de $35 \%$ (trinta e cinco por cento) da receita corrente líquida.

Exige o artigo 97 do ADCT, para os que optarem pelos depósitos mensais, que pelo menos $50 \%$ dos recursos de que tratam sejam utilizados para pagamento de precatórios em ordem cronológica de apresentação, respeitadas as preferências dos créditos de natureza alimentícia, para os requisitórios do mesmo ano, e para os créditos de natureza alimentícia para os idosos e portadores de doença grave para requisitórios de todos os anos.

precatórios devidos for inferior ao dos recursos destinados ao seu pagamento. De outro lado, escolhendo o depósito anual, ao final do prazo necessário para a liquidação de seu estoque, lembrando-se do prazo máximo de 15 anos estabelecido pelo artigo 97 do ADCT.

${ }^{143}$ A solução de pagamento do estoque de precatórios a partir de percentuais sobre a receita corrente líquida foi aventada no Voto do Ministro Gilmar Mendes no julgamento da Intervenção federal $n^{\circ} 2.127$, ao entendimento de que "não seria possível exigir o pagamento da totalidade dos precatórios relativos a créditos alimentares sem que, em contrapartida, se estabeleça uma análise sobre se tal pagamento encontra respaldo nos limites financeiros de um Estado zeloso com suas obrigações constitucionais". (IF 2127, Relator Min. Marco Aurélio, Relator p/ Acórdão: Min. Gilmar Mendes, Tribunal Pleno, julgado em 08/05/2003, DJ 22-08-2003). 
O restante dos recursos depositados poderá ser aplicado isoladamente ou simultaneamente para o pagamento dos precatórios por meio do leilão; para o pagamento à vista de precatórios não quitados em ordem única e crescente de valor por precatório; e ainda, poderão ser destinados a pagamento por acordo direto com os credores, na forma estabelecida por lei própria da entidade devedora, que poderá prever criação e forma de funcionamento de câmara de conciliação.

O Estado de São Paulo optou pelo depósito mensal de 1,5\% vezes 1/12 da receita corrente líquida de 12 meses encerrados no segundo mês anterior ao mês do depósito (conforme o artigo $1^{\circ}$ do Decreto estadual $\mathrm{n}^{\mathrm{o}}$ 55.300, de 30/12/2009 ${ }^{144}$ ), sendo mensalmente publicada Resolução da Secretaria da Fazenda que divulga o valor da receita corrente líquida do mês de referência.

Além disso, destina o Estado de São Paulo o restante dos recursos depositados para o pagamento à vista de precatórios não quitados, em ordem única e crescente de valor por precatório (conforme artigo $1^{\circ}$ do Decreto 56.646, de 06/01/2011).

O regime especial de depósitos mensais traz consequências relevantes para o Direito Tributário, como acima se mencionou, pois a teor do artigo 97, $\S 10$, inciso II do ADCT, no caso de não liberação tempestiva dos recursos relativos aos depósitos, poderá o Presidente do Tribunal requerido ordenar seja constituído em favor dos credores de precatórios, contra Estados, Distrito Federal e Municípios devedores, direito líquido e certo, autoaplicável e independentemente de regulamentação, à compensação automática com débitos líquidos lançados por esta contra aqueles, e, havendo saldo em favor do credor, o valor terá automaticamente poder liberatório do pagamento de tributos de Estados, Distrito Federal e Municípios devedores, até onde se compensarem.

Portanto, nãos sendo depositados os valores no seu correto tempo, confere-se ao Presidente do Tribunal requerido autorização para a determinação de compensação dos créditos de precatórios inadimplidos com os débitos que este por ventura tenha com o ente federado devedor.

Nessa situação, responderá o chefe do Poder Executivo na forma da legislação de responsabilidade fiscal e de improbidade administrativa. E, enquanto perdurar a omissão, enquanto perdurar a omissão, a entidade devedora não poderá contrair empréstimo externo ou interno, ficando, ainda, impedida de receber transferências voluntárias.

$\overline{1^{44} \text { Opção mantida pelos Decretos n }}{ }^{\circ}$ s. 57.658/2011 e 58.298/2012. 
Note-se que a constituição expressamente afastou a exigência de lei nessa hipótese de compensação. Ademais, por estarem os precatórios alimentares também abrangidos pelo regime especial do artigo 97 do ADCT, a possibilidade de compensação os alcança de igual maneira.

E, ainda que não esteja prevista expressamente a possibilidade de cessão de créditos inseridos no regime especial de pagamento do artigo 97 do ADCT, esta autorização é retirada diretamente do artigo 100 da Constituição da República ${ }^{145}$.

Nesse sentido leciona Fernando Facury Scaff ${ }^{146}$ :

A última norma que dispõe sobre os aspectos tributários na atual sistemática dos precatórios é o art. 97, parágrafo $15 \mathrm{da}$, e que contém uma "casca de banana interpretativa"em seu bojo.

Estabelece a norma que os precatórios parcelados na forma do art. 33 ou do art. 78 do ADCT e ainda pendentes de pagamento ingressarão no regime especial de criado pelo art. 97 (EC 62) com o valor atualizado das parcelas não pagas relativas a cada precatório, bem como com o saldo dos acordos judiciais e extrajudiciais.

A "casca de banana interpretativa" está no fato de que os precatórios alimentícios encontram-se expressamente excluídos dos parcelamentos compulsórios estabelecidos tanto pelo art. 33, quanto pelo art. 78 do ADCT. Ou seja, aparentemente, em uma leitura apressada, poder-se-ia concluir que os precatórios alimentícios teriam ficado de fora deste grande parcelamento estabelecido pelo art. 97 do ADCT.

Todavia, interpretar desse modo seria um erro, pois, embora seja verídico que os precatórios alimentícios não tenham entrado nos parcelamentos doas arts. $33 \mathrm{e}$ 78 do ADCT, uma vez que deveriam ser pagos a vista - e muitos não o foram, como acima comprovado, o caput do art. 97 alcança todos os valores que “estejam em mora na quitação de precatórios vencidos". Logo, os precatórios alimentares que estejam em mora encontram-se incluídos no parcelamento do artigo 97 do ADCT.

Desta forma, mesmo os precatórios alimentícios podem ser usados para pagamento de tributos, na hipótese do art. 97, parágrafo 10, II do ADCT e estão sujeitos à compensação compulsória prevista no artigo 97 , parágrafo $9^{\circ}$, II do ADCT.

${ }^{145}$ Observa-se que o artigo $5^{\circ}$ da Emenda Constitucional $n^{\circ} 62$ convalidou todas as cessões de precatórios efetuadas antes da promulgação desta Emenda Constitucional, independentemente da concordância da entidade devedora. No entanto, só a que se falar em convalidação se a cessão foi realizada de forma regular. $\mathrm{O}$ mesmo entendimento se aplica à convalidação das compensações, prevista no artigo $6^{\circ}$ da citada emenda constitucional. Sobre a convalidação das cessões, interessante comentário faz Fernando Facury Scaff: "Este é um aspecto muito importante para as operações fiscais anteriores à EC 62, pois várias dúvidas haviam no âmbito judicial sobre a possibilidade de cessão de créditos de precatórios. Alguns desses dissídios jurisprudenciais foram apresentados no meu trabalho antes mencionado. Logo, a disposição expressa convalidando todas as operações antes efetuadas é positiva, pois afasta dúvidas existentes nos tribunais - desde que realizadas de conformidade com o Direito então vigente, pois não pode haver convalidação contrária ao Direito, mesmo pela via constitucional." (SCAFF, Fernando Facury. Uso de precatórios para pagamento de tributos após a EC 62. Revista dialética de direito tributário, São Paulo, n. 175, abr. 2010. p. 94).

${ }^{146}$ Ibidem. p. 104. 
Por fim, reitera-se o alerta já feito, de que a Emenda Constitucional n ${ }^{\circ}$ 62/2009 é objeto de diversas Ações Diretas de Inconstitucionalidade. Cite-se a ADI n 4357/DF, que já apresenta voto do Ministro Relator, Ayres Britto, reconhecendo: a inconstitucionalidade da $E C n^{\circ} 62 / 2009$ por vício formal, vez que a proposta foi apresentada e votada no Senado Federal em duas sessões realizadas no mesmo dia, com intervalo de apenas uma hora entre elas; a inconstitucionalidade da expressão "na data da expedição do precatório", contida no $\S 2^{\circ}$ do art. 100 da Constituição Federal; como também julgou inconstitucionais os $\S \S 9^{\circ} \mathrm{e}$ 10 do artigo 100 da Constituição da República, por entender que o citado dispositivo ofende o direito ao devido processo legal, ao contraditório e à ampla defesa ao permitir que o Estado realizar a compensação de ofício, dentre outras. No que tange ao artigo 97 do ADCT, o voto do in. Relator é pela inconstitucionalidade de todo o dispositivo.

A questão da compensação será retomada adiante.

\subsubsection{O estoque de precatórios, o poder liberatório para pagamentos de tributos e a criação de um mercado de precatórios}

Viu-se acima que o pagamento parcelado dos precatórios existentes à época da promulgação da Constituição da República de 1988, em oito anos, conforme idealizado pelo artigo 33 do Ato das Disposições Constitucionais Transitórias ${ }^{147}$, não foi suficiente para evitar a formação de um novo estoque de precatórios.

Pode-se atribuir o insucesso da medida a diversos fatores, tais como a descontrolada inflação que assolava o país, a escassez dos recursos públicos e a alternância de grupos políticos no poder, em razão de certa indisposição política dos novos governantes eleitos em pagar dívidas públicas originadas nas gestões anteriores.

Contudo, a justificativa mais comum para o não pagamento de precatórios, e que há tempos é acolhida pelo Supremo Tribunal Federal ${ }^{148}$, é ausência de dolo na inadimplência,

\footnotetext{
${ }^{147}$ Art. 33 do ADCT: "Ressalvados os créditos de natureza alimentar, o valor dos precatórios judiciais pendentes de pagamento na data da promulgação da Constituição, incluído o remanescente de juros e correção monetária, poderá ser pago em moeda corrente, com atualização, em prestações anuais, iguais e sucessivas, no prazo máximo de oito anos, a partir de $1^{\circ}$ de julho de 1989 , por decisão editada pelo Poder Executivo até cento e oitenta dias da promulgação da Constituição".

${ }^{148}$ Nessa linha, cite-se, novamente, os seguintes julgados: IF 5101, Relator Min. Cezar Peluso (Presidente), Tribunal Pleno, acórdão eletrônico DJe- 05-09-2012; IF 506 AgR, Relator Min. Maurício Corrêa,
} 
sob o fundamento de que o pagamento de precatórios poderia comprometer, ou no mínimo prejudicar, a efetivação de outros direitos constitucionalmente protegidos como a saúde, a educação e a segurança pública, que comprometem parte significativa do orçamento. Isso sem mencionar o alegado óbice à realização das políticas públicas consideradas essenciais àquele ente federado, sustentando-se, ainda, que o pagamento da dívida de precatórios poderia por em risco a folha de pagamento dos servidores públicos.

O fato é que a ineficácia do parcelamento de precatórios em oito anos e o constante crescimento da dívida pública da União, dos Estados e dos Municípios nos anos que se seguiram à promulgação da Constituição de 1988, contribuíram, sem sombra de dúvida, para que fosse pensada uma nova modalidade de parcelamento que pudesse por fim ao problema do não pagamento de precatórios, sem, contudo, comprometer a situação financeira de Estados e Municípios devedores.

Referido parcelamento, como adiantado no tópico precedente, foi concretizado com pela Emenda Constitucional n ${ }^{\circ} 30$, de 13 de setembro de 2000, que inseriu o artigo 78 ao Ato das Disposições Constitucionais Transitórias, com a seguinte redação:

\begin{abstract}
Art. 78. Ressalvados os créditos definidos em lei como de pequeno valor, os de natureza alimentícia, os de que trata o art. 33 deste Ato das Disposições Constitucionais Transitórias e suas complementações e os que já tiverem os seus respectivos recursos liberados ou depositados em juízo, os precatórios pendentes na data de promulgação desta Emenda e os que decorram de ações iniciais ajuizadas até 31 de dezembro de 1999 serão liquidados pelo seu valor real, em moeda corrente, acrescido de juros legais, em prestações anuais, iguais e sucessivas, no prazo máximo de dez anos, permitida a cessão dos créditos.
\end{abstract}

Note-se que o parcelamento constitucional de precatórios instituído pela Emenda Constitucional $n^{\circ} 30 / 2000$ excepcionava diversos créditos, como os precatórios alimentares. De outro lado, ampliou-se o número de parcelas em relação ao parcelamento anterior, do artigo 33 do ADCT, passando de oito para dez as parcelas anuais para a quitação do débito representado pelo precatório.

No entanto, a inovação introduzida pela Emenda Constitucional $n^{\circ} 30 / 2000$ que mais causou polêmica, foi a previsão do $\S 2^{\circ}$ do artigo 78 do ADCT que preconizava que as prestações anuais do parcelamento que não fossem liquidadas até o final do exercício a que ele se referia teriam "poder liberatório do pagamento de tributos da entidade devedora".

Tribunal Pleno, DJ 25-06-2004; e IF 298, Relator Min. Marco Aurélio, Relator(a) p/ Acórdão Min. Gilmar Mendes, Tribunal Pleno, DJ 27-02-2004. 
Somados o poder liberatório para o pagamento de tributos e a possibilidade de cessão dos precatórios, previstos, respectivamente, no parágrafo segundo e na parte final do caput do artigo 78 do ADCT, ter-se-ia uma solução de mercado para o pagamento do estoque de precatórios no Brasil ${ }^{149}$.

Segundo defende Vincenzo Demetrio Florenzano ${ }^{150}$, a solução de mercado teria sido o verdadeiro objetivo da Emenda Constitucional $n^{\circ} 30 / 2000$, pois a criação de um mercado para o problema do estoque de precatórios representaria alternativa possivelmente eficiente e, talvez, a melhor forma de se forçar o pagamento dos precatórios.

Pondera ainda Vincenzo Demetrio Florenzano"151, a partir de uma "Análise Econômica do Direito", que "formando-se um mercado de precatórios, é possível transformar esse capital morto que temos hoje (precatório) em capital vivo, capaz de dinamizar a propriedade."

De outro lado, Vincenzo Demetrio Florenzano ${ }^{152}$ se questiona se os precatórios poderiam desempenhar as funções de uma mercadoria, pois a formação de um mercado não dependeria apenas de um título representativo de crédito, mas, sobretudo, que este título tivesse valor mobiliário. Nesse diapasão, sugere o aludido autor a seguinte proposta formação de mercado ${ }^{153}$ :

Como o milho, a soja, o trigo ou qualquer outra commodity, o crédito dos precatórios pode ser alocado por meio de um sistema de preços que direciona o bem para o usuário que the atribui maior valor. No caso do crédito, o preço são os termos em que o banco pode negociar no contrato de empréstimo. Se as instituições financeiras podem conseguir melhores termos de troca, não há por que impedir a transferência do crédito para o usuário que lhe atribui maior valor.

Além disso, o mercado pode promover maior especialização, porque os bancos e as demais instituições financeiras que se interessarem pelo mercado de precatórios teriam maior incentivo em desenvolver know-how em realizar esse tipo de operação. Podem surgir também outros interessados em atuar nesse mercado. Aqueles que forem mais bem-sucedidos nesse tipo de operação poderão vender seus serviços às demais instituições. Por intermédio da concorrência, os mais eficientes nas realizações dessas operações conquistariam essa nova fatia do mercado.

O grande benefício para os credores de precatório, portanto, segundo aponta Florenzano ${ }^{154}$, seria a possibilidade de transformar o crédito representado por um precatório

\footnotetext{
${ }^{149}$ Cf. FLORENZANO, Vincenzo Demetrio. A emenda constitucional n. 30, de 13.9.2000, sob a perspectiva da análise econômica do direito. In: VAZ, Orlando (coord.). Precatórios: problemas e soluções, Belo Horizonte: Del Rey, 2005. p. 218.

${ }^{150}$ Ibidem. loc. cit.

${ }^{151}$ Ibidem. loc.cit.

${ }^{152}$ Ibidem. p. 220

${ }^{153}$ Ibidem. p. 232.

${ }^{154}$ Ibidem. p. 218.
} 
em dinheiro vivo, ainda que com significativo deságio e considerável custo operacional. Em contrapartida, para Fazenda Pública haveria o aspecto negativo da diminuição da arrecadação, na medida em que estes créditos fossem compensados com tributos devidos pelos adquirentes de precatórios.

Nesse ponto, já é possível vislumbrar as duas formas de fomento do mercado de precatórios. A primeira, que é o escopo deste estudo, se caracterizaria com a aquisição de precatórios pelos devedores de tributos por valores bem inferiores ao de face, com o objetivo de utilizá-los em procedimento de compensação tributária. A segunda hipótese, por sua vez, verificar-se-ia com a aquisição de precatórios por instituições financeiras, em regra, para a constituição de fundos de investimentos, que lucrariam tanto pelo pagamento do valor de face superior ao de aquisição (deságio), como também pela atualização dos valores no momento do pagamento. Neste último caso não haveria compensação, ou qualquer violação à ordem cronológica de pagamento dos precatórios, pois os "fundos de precatórios" receberão como se credores originais fossem.

A primeira opção - compensação-, foi a que mais chamou a atenção a partir da vigência do artigo $78, \S 2^{\circ}$ do $\mathrm{ADCT}$, pois, diante da enorme oferta de precatórios, e respectivo deságio para a sua compra, somado a novidade da previsão de cessão de precatórios em sede constitucional, além do fato de ser uma novidade legislativa, não havendo posicionamentos firmados administrativa como judicialmente, este era o caminho que se mostrava mais atraente economicamente.

Não é difícil compreender esse fenômeno, pois, conquanto fosse incerta a realização da compensação tributária e temerárias as teses defendidas pelos contribuintes, a simples existência de uma norma constitucional conferindo ao precatório força suficiente para liberar o devedor de um tributo do vínculo obrigacional, mesmo que não fosse ele o credor original deste precatório, aliada ao fato de que era baixíssimo o valor de mercado de um precatório, cerca de $30 \%$ do seu valor de face, já tornava extremamente lucrativo o comércio de precatórios com vistas à utilização em procedimento de compensação, mesmo que, por vezes, aquela compensação fosse, em verdade, apenas um "fôlego fiscal" que os cessionários obtinham, tanto administrativamente como judicialmente, já que, em regra, os pedidos eram indeferidos, pelas razões que adiante serão analisadas.

Isso não significa discordar do fato de que a previsão de atribuição de poder liberatório para pagamento de tributos aos precatórios cujas parcelas fossem inadimplidas, conforme artigo $78, \S 2^{\circ}$ do ADCT, conjugada com a possibilidade de cessão desses 
precatórios inserta no caput do referido artigo constitucional, tinham como finalidade fomentar a realização de compensações.

Contudo, essa opção não se mostrou a melhor, muito em razão das restrições impostas pelo próprio ordenamento jurídico para a realização de compensações em matéria tributária, como a exigência de lei, nos termos do artigo 170 do Código Tributário Nacional, a vedação constitucional em relação aos precatórios alimentares, além da restrição quanto a compensação entre pessoas jurídicas distintas, questões que adiante serão analisadas, em capítulo específico.

Em contrapartida, as aquisições de precatórios para a constituição de "fundos de precatórios", que se mostrou tímida de início, apresentou grande crescimento nos últimos anos, notadamente com o advento da Emenda Constitucional $n^{\circ} 62 / 2009^{155}$.

Esse aumento na movimentação de precatórios por parte das instituições financeiras não está relacionado à possibilidade de se atribuir poder liberatório aos precatórios inseridos no regime especial de pagamento, para a sua utilização em compensações tributárias, ${ }^{156}$, antes, resultada da nova redação dada pela Emenda Constitucional $\mathrm{n}^{\mathbf{o}}$ 62/2009 ao artigo 100 da Constituição da República, que prevê tanto os critérios para a atualização dos precatórios, como também a possibilidade de cessão dos precatórios sem a necessidade da expressa concordância do credor.

Com efeito, desde a promulgação desta Emenda Constitucional n ${ }^{\circ}$ 62/2009, o artigo $100, \S 12$ da Constituição da República determina que a atualização dos precatórios, desde sua expedição até o efetivo pagamento, independentemente de sua natureza, será feita pelo índice oficial de remuneração básica da caderneta de poupança e, para fins de compensação da mora, incidirão juros simples no mesmo percentual de juros incidentes sobre a caderneta de poupança, ficando excluída a incidência de juros compensatórios.

No tocante à cessão, estabelece o artigo 100, § 13 da Constituição Federal que o credor poderá ceder, total ou parcialmente, seus créditos em precatórios a terceiros, independentemente da concordância do devedor, ressalvando-se, consoante o artigo 100, $\S$

${ }^{155}$ No início do ano de 2010, três novos fundos de precatórios foram registrados na Comissão de Valores Mobiliários (CVM) e um quarto estava em análise, somando R\$ 1,9 bilhão. O valor é bastante superior aos cerca de R\$ 400 milhões em fundos de precatórios criados em 2009. Fonte: Valor Econômico, $13 / 04 / 2010$.

156 Conforme já exposto, a Emenda Constitucional n 62/2009 criou previsão de atribuição de poder liberatório aos precatórios para compensação tributária, a qual será possível, sempre por ordem do Presidente do Tribunal requerido, nas hipóteses de inadimplência ou atraso do na liberação dos recursos para o regime especial dotado, nos termos do artigo 97 do ADCT (artigo 97, § 10, inciso II, do ADCT). 
14, que a cessão de precatórios somente produzirá efeitos após a comunicação, por meio de petição protocolizada, ao tribunal de origem e à entidade devedora ${ }^{157}$.

Logo, a partir da publicação da Emenda Constitucional n 62/2009, tornou-se mais segura a cessão dos créditos representados por precatórios, bem como se pôde antever com mais segurança o valor que será efetivamente pago pelo título de crédito (precatório) cedido, em razão de estarem os critérios de atualização da dívida constitucionalmente assegurados.

Tais fatores indiscutivelmente ajudaram o aquecimento do mercado, estimulando a criação dos comentados "fundos de precatórios", isso sem mencionar a atual política de redução de juros no país, que também contribuíram para que os precatórios se tornassem um bom investimento em longo prazo.

Compartilha desse entendimento Américo Luís Martins da Silva ${ }^{158}$ :

\begin{abstract}
Vale ainda acrescentar que a mudança na forma de pagamento dos precatórios (dívidas dos governos federal, estaduais e municipais) feita pela EC 62/2009 provocou a movimentação do "mercado de fundos de dívidas judiciais dos governos". Desde o início do ano de 2010 vários "fundos de precatórios" foram registrados na Comissão de Valores Mobiliários - CVM, somando cifras superiores a R\$ 2 bilhões. Com efeito, o valor é bastante superior aos cerca de R\$ 400 milhões em fundos de precatórios criados em 2009 e só se equipara aos lançamentos ao longo de 2008. Isto decorre do fato de a EC 62/2009 ter uniformizado a correção das dívidas, tornando possível, a partir de então, se ter conhecimento exato do valor do precatório que será pago, por exemplo, após 10 (dez) anos de espera, o que não ocorria antes da vigência desta Emenda Constitucional. Assim, as novas disposições transformaram os precatórios em títulos negociáveis, aos mesmos (sic) teoricamente. Certamente, com mais previsibilidade tanto para o prazo quanto para os valores de recebimento, a expectativa dos gestores dos "fundos de precatórios" é que haja maior movimentação dos títulos, o qual assegura negócio interessante para investidores, sejam eles empresas ou pessoas físicas que têm créditos a receber dos governos federal, estaduais e municipais.
\end{abstract}

Corrobora essa tendência a reportagem veiculada pelo jornal O Estado de São Paulo, em 19 de abril de $2010^{159}$, na qual se constata que, depois da publicação da Emenda Constitucional $n^{\circ} 62 / 2009$, o próprio valor de aquisição dos precatórios no mercado foi elevado, sendo estes agora adquiridos pelos "Fundos de Direitos Creditórios- FDICs" por $70 \%$ do respectivo valor de face, enquanto antes do novo regramento constitucional, o preço não chegava a $30 \%$ do valor de face.

\footnotetext{
${ }^{157}$ Anote-se que aos cessionários não se estendem os privilégios do artigo $100, \S 2^{\circ}$ e tampouco a sistemática das obrigações de pequeno valor, previstas no artigo $100, \S 3^{\circ}$.

${ }^{158}$ SILVA, Américo Luís Martins da, Precatório-requisitório e requisição de pequeno valor (RPV). 4. ed. São Paulo: Revista dos Tribunais, 2010. p. 235.

159 Disponivel em: <http://www.estadao.com.br/noticias/impresso,mercado-de-precatorios,540186,0.htm>. Acesso em: 19 nov. 2012.
} 
Em síntese, pretendeu-se demonstrar neste tópico que a criação de uma solução de mercado para o problema dos precatórios não está necessariamente atrelada à ideia de compensação tributária, e, nessa linha, que a opção de formação de um mercado de precatórios é mais interessante no que se refere aos "fundos de precatórios" criados e administrados por instituições financeiras, na medida em que, nesta opção, não se faz necessário o enfrentamento dos controvertidos pontos que cercam as compensações tributárias, como a ordem cronológica para o pagamento do precatório e a necessidade de se honrar as vinculações constitucionais sem o respectivo ingresso de receita, problemas que adiante serão melhores analisados.

\subsection{A Requisição de Pequeno Valor}

O artigo 100 da Constituição da República estabelece a regra geral de que o pagamento dos valores devidos pela Fazenda Pública em decorrência de sentenças judiciais transitadas em julgado seja realizado de acordo com a sistemática dos precatórios.

Contudo, a Lei $n^{\circ} 8.213$ de 24 de julho de 1991, que dispõe sobre os Planos de Benefícios da Previdência Social, em seu artigo 128, na sua redação original, excetuou da regra geral dos precatórios as condenações de menor monta que eram impostas ao Instituto Nacional do Seguro Social - INSS, criando uma espécie de liquidação imediata de dívidas originadas em ações judiciais cujo valor não superasse $\mathrm{Cr} \$ 1.000 .000,00$ (um milhão de cruzeiros), não sendo aplicáveis, nestes casos, as disposições dos artigos 730 e 731 do Código de Processo Civil.

O valor máximo para o referido pagamento imediato foi aumentado para Cr\$1.000.000,00 (um milhão de cruzeiros) por autor pela Lei $n^{\circ} 8.620 / 93$, e para $\mathrm{R} \$$ 4.988,57 (quatro mil, novecentos e oitenta e oito reais e cinqüenta e sete centavos de real) pela Lei $n^{\circ} 9.032 / 95$.

O citado artigo 128 da Lei $n^{\circ} 8.213 / 91$ (e suas alterações até a Lei $n^{\circ}$ 9.032/95) foi objeto da ação direta de inconstitucionalidade, ADI $n^{\circ} 1252 / \mathrm{DF}$, a qual foi julgada parcialmente procedente, sendo reconhecida pelo Supremo Tribunal Federal a inconstitucionalidade da seguinte expressão contida no artigo 128 da Lei 8.213/91: "e 
liquidadas imediatamente, não se lhes aplicando o disposto nos arts. 730 e 731 do Código de Processo Civil". Assim restou ementado o acórdão:

\begin{abstract}
AÇÃO DIRETA DE INCONSTITUCIONALIDADE. DÉBITO JUDICIAL. DISPENSA DE PRECATÓRIO TENDO EM CONSIDERAÇÃO O VALOR DA CONDENAÇÃO: ART. 128 DA LEI 8.213/91. INCONSTITUCIONALIDADE PARCIAL DA NORMA FRENTE AO DISPOSTO NO ART. 100 DA CONSTITUIÇÃO FEDERAL. RESOLUÇÃO N ${ }^{\circ}$ 5 DO CONSELHO NACIONAL DE PREVIDÊNCIA SOCIAL: ART. $5^{\circ}$. NÃO CONHECIMENTO.
\end{abstract}

1. O preceito ínsito ao art. 100 da Constituição Federal proíbe a designação de casos ou de pessoas nas dotações orçamentárias e nos créditos adicionais, tendo em vista a observação de preferência. Por isso, a dispensa de precatório, considerando-se o valor do débito, distancia-se do tratamento uniforme que a Constituição objetivou conferir à satisfação dos débitos da Fazenda. 1.1. Inconstitucionalidade da expressão contida no art. 128 da Lei 8.213/91: "e liquidadas imediatamente, não se lhes aplicando o disposto nos arts. 730 e 731 do Código de Processo Civil".

2. Art. $5^{\circ}$ da Resolução $n^{\circ} 5$ do Conselho Nacional de Previdência Social. Controvérsia que se circunscreve à legalidade e não constitucionalidade do ato normativo. Ação Direta de Inconstitucionalidade não conhecida, nesta parte.

2.1. A Resolução está umbilicalmente vinculada ao art. 128 da Lei 8.213/91, e a declaração de inconstitucionalidade parcial deste preceito retira-lhe 0 sustentáculo para a sua existência na ordem jurídica e, por conseqüência, a sua aplicabilidade. Ação direta de inconstitucionalidade parcialmente procedente.

(ADI 1252, Relator MinistroMaurício Corrêa, Tribunal Pleno, julgado em 28/05/1997, DJ 24-10-1997, PP-54156 EMENT VOL-01888-01 PP-00082)

A ausência de previsão constitucional para a validade de pagamento diferenciado para as dívidas de pequeno valor foi suprida pelo artigo $1^{\circ}$ da Emenda Constitucional $n^{\circ} 20$ de 1998 , que inseriu o parágrafo $3^{\circ}$ ao artigo 100 , que passou a prever que a sistemática dos precatórios não mais se aplicava "aos pagamentos de obrigações definidas em lei como de pequeno valor que a Fazenda Federal, Estadual ou Municipal deva fazer em virtude de sentença judicial transitada em julgado".

Observa-se que a redação do citado dispositivo não contemplava as obrigações de pequeno valor devidas pelo Distrito Federal. Tal omissão foi sanada pela Emenda Constitucional $\mathrm{n}^{\circ} 30$ de $2000^{160}$, que determinou a seguinte redação ao artigo $100, \S 3^{\circ}$ da Constituição de 1988:

$\S 3^{\circ} \mathrm{O}$ disposto no caput deste artigo [artigo 100], relativamente à expedição de precatórios, não se aplica aos pagamentos de obrigações definidas em lei como de pequeno valor que a Fazenda Federal, Estadual, Distrital ou Municipal deva fazer em virtude de sentença judicial transitada em julgado.

${ }^{160}$ Foi reconhecido pelo Supremo Tribunal Federal, nos autos do recurso extraordinário n ${ }^{\circ}$ 578.812/RG, a existência de repercussão geral sobre a possibilidade de conversão de precatório expedido antes da Emenda Constitucional $n^{\circ}$ 37/2002 em requisição de pequeno valor (RE 578812 RG, Relator Ministro Ricardo Lewandowski, DJe 23-10-2008). 
Assim, com fundamento no artigo $100, \S 3^{\circ}$ da Constituição da República foi editada a Lei $\mathrm{n}^{\circ} 10.099$ de 12 de dezembro de 2000, que alterou o artigo 128 da Lei $\mathrm{n}^{\circ}$ $8.213 / 91$, o qual passou a conter a seguinte redação:

Art. 128. As demandas judiciais que tiverem por objeto o reajuste ou a concessão de benefícios regulados nesta Lei cujos valores de execução não forem superiores a R $\$ 5.180,25$ (cinco mil, cento e oitenta reais e vinte e cinco centavos) por autor poderão, por opção de cada um dos exeqüentes, ser quitadas no prazo de até sessenta dias após a intimação do trânsito em julgado da decisão, sem necessidade da expedição de precatório.

Logo, permite-se hoje que o exequente receba em até sessenta dias o valor devido pelo INSS, desde que tal quantia esteja limitada ao teto do pequeno valor, sem que haja necessidade de expedição de precatório.

Deve-se notar que os parágrafos do artigo 128 da Lei ${ }^{\circ}$ 8.213/91 impõem restrições ao pagamento realizado pelo INSS fora da sistemática dos precatórios, a saber:

(i) é vedado o fracionamento, repartição ou quebra do valor da execução, de modo que o pagamento se faça, em parte, na forma estabelecida no caput e, em parte, mediante expedição do precatório;

(ii) também é vedada a expedição de precatório complementar ou suplementar do valor pago em sessenta dias sem expedição de precatório; e

(iii) se o valor da execução ultrapassar o estabelecido como teto para o pagamento de pequeno valor, este deverá ser realizado por meio de precatório.

De outro lado, faculta a lei que o exequente renuncie ao montante do crédito que excede o estabelecido como sendo de pequeno valor, para que ele possa optar pelo pagamento do saldo sem o precatório. Conforme expressamente previsto pelo artigo $128, \S$ 50: "A opção exercida pela parte para receber os seus créditos na forma prevista no caput implica a renúncia do restante dos créditos porventura existentes e que sejam oriundos do mesmo processo".

A mesma sistemática de pagamento para valores de menor monta é aplicada no juizado especial federal, instituído pela Lei $\mathrm{n}^{\circ} 10.259$, de 12 de julho de 2001, cuja competência é limitada às causas cujo valor não exceda sessenta salários mínimos, cabendo-lhe, também, a execução de suas decisões.

Com efeito, nos termos do artigo 17 da Lei $\mathrm{n}^{\circ}$ 10.259/01, após o trânsito em julgado da decisão proferida no processo que teve trâmite no juizado especial federal, o 
pagamento da dívida imposta à Fazenda Federal será efetuado no prazo de sessenta dias, contados da entrega da requisição, por ordem do Juiz, à autoridade citada para a causa, independentemente de precatório.

A não sujeição das obrigações de pequeno valor à sistemática dos precatórios foi mantida pela Emenda Constitucional n ${ }^{\circ} 62$ de 2009, permanecendo o artigo 100, $\S 3^{\circ}$ com a mesma redação dada pela Emenda Constitucional n 30 de 2000.

A novidade trazida pela Emenda Constitucional $n^{\circ} 62 / 09$, no que se refere às obrigações de pequeno valor, é a já citada inclusão do artigo $100, \S 4^{\circ}$ da Constituição da República, que estabelece que o "pequeno valor" poderá ser fixado por leis próprias da União, Estados, Distrito Federal e Município, inclusive com valores distintos às entidades de direito público, segundo as diferentes capacidades econômicas, sendo o mínimo igual ao valor do maior benefício do regime geral de previdência social ${ }^{161}$.

Ademais, nos termos do artigo 87 do Ato das Disposições Constitucionais Transitórias, também regulamentado pela Emenda Constitucional $\mathrm{n}^{\circ}$ 62/09, serão considerados de pequeno valor, até que se dê a publicação oficial das respectivas leis definidoras pelos entes da Federação, observado o disposto no $\S 4^{\circ}$ do artigo 100 da Constituição Federal, os débitos ou obrigações consignados em precatório judiciário, que tenham valor igual ou inferior a quarenta salários-mínimos, perante a Fazenda dos Estados e do Distrito Federal e trinta salários-mínimos, perante a Fazenda dos Municípios.

Se o valor da execução ajuizada contra a Fazenda Pública ultrapassar o estabelecido no artigo 87 do ADTC, o pagamento deverá ser realizado por meio de precatório, sendo, contudo, facultada à parte exequente a renúncia ao crédito do valor excedente, para que possa optar pelo pagamento do saldo sem o precatório, na forma prevista no artigo 100, $\S$ $3^{\circ}$ da Constituição da República (artigo 87, parágrafo único do ADCT).

Os valores considerados como obrigações de pequeno valor, estabelecidos pelo artigo 87 do ADCT, também deverão ser observados pelos os Juizados Especiais da Fazenda Pública no âmbito dos Estados, do Distrito Federal, dos Territórios e dos Municípios, até que haja lei específica ${ }^{162}$.

\footnotetext{
${ }^{161}$ O Estado de São Paulo editou a Lei n ${ }^{\circ} 11.377$, de 14 de abril de 2003, regulamentando o artigo 100, § $3^{\circ}$ da Constituição Federal, fixando como obrigação de pequeno valor aquela cujo valor seja igual ou inferior a 1.135,2885 Unidades Fiscais do Estado de São Paulo - UFESPs, independente da natureza do crédito.

${ }^{162}$ Lei n ${ }^{\circ} 12.153$ de 22 de dezembro de 2009.
} 
De acordo como a Lei $n^{\circ} 12.153 / 2009$, após o trânsito em julgado da decisão proferida pelos Juizados Especiais da Fazenda Pública, as obrigações de quantia certa serão pagas no prazo máximo de 60 (sessenta) dias, contado da entrega da requisição do juiz à autoridade citada para a causa, independentemente de precatório. De outro lado, o pagamento deverá ser realizado por precatório sempre que o montante da condenação exceder o valor definido como obrigação de pequeno valor, que para efeitos da Lei $n^{\circ}$ 12.153/09, será de 40 (quarenta) salários mínimos, em relação aos Estados e ao Distrito Federal e de 30 (trinta) salários mínimos, quanto aos Municípios.

Para o pagamento independente de expedição de precatório, nos termos da Lei $\mathrm{n}^{\circ}$ 12.153/09, são vedados o fracionamento, a repartição ou a quebra do valor da execução, de modo que o pagamento se faça, em parte, em sessenta dias e em parte, mediante expedição de precatório, bem como a expedição de precatório complementar ou suplementar do valor pago.

Ademais, do mesmo modo que nos juizados especais federais, se o valor da execução ultrapassar o estabelecido para pagamento independentemente do precatório, o pagamento será realizado por meio do precatório, sendo facultada à parte exequente a renúncia ao crédito do valor excedente, para que ele possa optar pelo pagamento do saldo sem o precatório ${ }^{163}$.

Em suma, há previsão constitucional e legal autorizando o pagamento da dívida pública decorrente de decisão judicial no prazo de sessenta dias sem que seja necessária a expedição de precatório $^{164}$, desde que o valor da condenação seja considerado por lei como obrigação de pequeno valor.

Entretanto, como não se vislumbra a utilização de obrigações de pequeno valor para fins tributários, haja vista a celeridade de seu pagamento e a inexistência de estoque de obrigações de pequeno valor pelos entes federados, e suas autarquias, estes não serão apreciados neste estudo ${ }^{165}$.

${ }^{163}$ Encontra-se pendente de julgamento no Supremo Tribunal Federal o recurso extraordinário $\mathrm{n}^{\circ} \mathrm{RE}$ 564.132, que teve reconhecida a repercussão geral sobre a possibilidade do fracionamento do valor da execução proposta contra a Fazenda Pública de Estado-membro, para pagamento de honorários advocatícios (decisão publicada em 28-03-2008, Relator Ministro Luiz Fux).

${ }^{164}$ Conforme leciona Regis Fernandes de Oliveira, para as requisições de pequeno valor "não há necessidade de expedição de precatório. A ordem é dada diretamente pelo juiz da execução à autoridade administrativa." (OLIVEIRA, Regis Fernandes de. Curso de direito financeiro. São Paulo: RT, 2006, p.524).

${ }^{165}$ Importante ressalvar que a matéria apresenta relevância no que se refere à compensação realizada antes da expedição do precatório, nos termos do artigo $100, \S 9^{\circ}$ da Constituição da República, tendo em vista a repercussão geral acerca da possibilidade, ou não, de compensação de débitos tributários com requisições 


\section{A UTILIZAÇÃo dE PRECATÓRIOS COMO FORMA DE EXTINÇÃo DE CRÉDITOS TRIBUTÁRIOS}

A presente dissertação parte da seguinte hipótese: é possível a utilização de precatórios como forma de extinção do crédito tributário? Se sim, em quais situações?

A primeira situação em que se vislumbra ser possível a utilização de precatórios como forma de extinção do crédito tributário é o pagamento, conforme se passa a expor.

\subsection{O precatório e a extinção do crédito tributário pelo pagamento}

A tese de que seriam os precatórios aptos a extinguirem o crédito tributário pelo pagamento teve origem com a promulgação da Emenda Constitucional $n^{\circ} 30$, de 13 de setembro de 2000, que instituiu o parcelamento decenal dos precatórios, inserindo o artigo 78 no Ato das Disposições Constitucionais Transitórias, prevendo, ainda, no parágrafo segundo do mesmo artigo 78 do ADCT, que as prestações anuais do parcelamento estabelecido que não fossem liquidadas até o final do exercício a que se referem, teriam poder liberatório do pagamento de tributos da entidade devedora.

É que a previsão de atribuição de poder liberatório para pagamento de tributos aos precatórios submetidos ao parcelamento decenal foi entendida por alguns como uma permissão para que se pagassem tributos com precatórios.

Essa é a leitura que faz Roberto Ferraz ${ }^{166}$, para quem "a hipótese que se identifica no parágrafo $2^{\circ}$, do art. 78 das Disposições Constitucionais Transitórias, conforme disposto na Emenda 30, é de simples pagamento de tributos com moeda própria para seu pagamento, e não de compensação". Partindo dessa premissa, pondera que "O Brasil tem hoje uma moeda universal, o real, e diversas moedas locais, com circulação restrita: os

de pequeno valor - RPV reconhecida pelo Supremo Tribunal Federal, nos autos do recurso extraordinário $\mathrm{n}^{\circ}$ 657.686/DF, em 16/12/2011. Nesse ponto, o assunto será analisado adiante.

166 FERRAZ, Roberto. O pagamento de tributos com precatórios: caso de uso de moeda e não de compensação: a inconstitucionalidade dinâmica da vedação à compensação. In: ROCHA, Valdir de Oliveira. Grandes questões atuais do direito tributário v. 13. São Paulo: Dialética, 2009 p. 352. 
precatórios vencidos e não pagos na forma da Emenda 30 e que servem para o pagamento apenas dos tributos das entidades deles devedoras" ${ } 167$.

Na mesma direção, Paulo Roberto Lyrio Pimenta ${ }^{168}$ :

Logo, a Emenda permitiu o pagamento de tributo por meio de um documento que consigna um crédito contra o Poder Público, o que vai ao encontro do conceito previsto no art. $3^{\circ}$ do CTN, o qual prescreve ser o tributo uma prestação pecuniária ou "cujo valor nela se possa exprimir".

Adiante conclui o citado professor ${ }^{169}$ : "O conceito legal transcrito no $\mathrm{CTN}$, pois, permite que o tributo possa ser pago em moeda ou em algo que tenha força de moeda, como é o caso dos precatórios em pauta".

Para se verificar a plausibilidade da tese que defende serem os precatórios aptos a extinguirem o crédito tributário pelo pagamento, mostra-se necessário recuperar algumas premissas já fixadas.

Discorreu-se no início do texto que a obrigação tributária é essencialmente pecuniária, de modo que a sua satisfação somente é possível com a entrega de dinheiro pelo sujeito passivo aos cofres públicos. Em direito tributário, portanto, o pagamento de um tributo ocorre, exclusivamente, com a entrega, pelo devedor, da moeda que tenha curso regular no país. Não há qualquer exceção a isso na redação do artigo $3^{\circ}$ do Código Tributário Nacional.

Nesse sentido, são precisos os ensinamentos, já citados, de Luís Eduardo Schoueri ${ }^{170}$, que esclarece a linguagem do legislador:

Mas se é 'em moeda', porque a expressão 'ou cujo valor nela se possa exprimir'?
Esse cuidado do legislador se deve ao fato de que, por vezes, o tributo não é
pago, diretamente, em moeda: o contribuinte compra, com moeda, um selo ou
estampilha e o tributo é pago com a utilização da última. Assim, por exemplo, o
selo que se põe nas embalagens de cigarros e bebidas. Ou seja: o pagamento do
tributo dá-se com o uso da estampilha, mas esta, por óbvio, tem o valor expresso
em moeda.

Também contundente é a lição de Sacha Calmon Navarro Côelho ${ }^{171}$, a qual se pede licença para, novamente, transcrever:

Obviamente pode o credor, no caso o Estado, se quiser e autorizado pela lei, aceitar em dação em pagamento um bem que não dinheiro. Incidem em erronia

\footnotetext{
${ }^{167}$ Ibidem. loc. cit.

${ }^{168}$ PIMENTA, Paulo Roberto Lyrio. O Pagamento de tributos por meio de créditos relativos aos precatórios judiciais. Revista dialética de direito tributário, São Paulo, n. 177, 2010, p. 124.

169 Ibidem. p. 125.

${ }^{170}$ SCHOUERI, Luís Eduardo. Direito tributário. São Paulo: Saraiva, 2011. p. 133.

${ }^{171}$ CÔELHO, Sacha Calmon Navarro. Curso de direito tributário. 11. ed. Rio de Janeiro: Forense, 2010. p 660 .
} 
os que enxergam na cláusula valor que nela se possa exprimir uma licença para pagar tributos com vacas, coelhos ou hortaliças. É que se pode pagar com selos ou estampilhas. A obrigação tributária é de dar coisa certa.

Forte nessas considerações, conclui-se que o termo "pagamento" é utilizado pelo artigo 156, inciso I do Código Tributário Nacional, em referência ao artigo $3^{\circ}$ do mesmo diploma legal, em seu sentido estrito, correspondente à entrega de dinheiro (moeda corrente) pelo sujeito passivo da obrigação tributária aos cofres públicos.

Resta, assim, definir se a partir do termo "pagamento", do artigo 78, § $2^{\circ}$ do ADCT, é válido equiparar a moeda, de que se vale o Código Tributário Nacional, nos artigos 156, inciso I e 162, inciso I, ao precatório que possua poder liberatório para pagamento de tributos.

Segundo ensina Roberto Quiroga Mosquera ${ }^{172}$, para algo ser considerado moeda, deverão estar presentes os seguintes elementos: (i) ser bem fungível, podendo ser tocado por outro de mesma qualidade, quantidade e espécie; (ii) ter sido determinado pelo Direito, na medida em que só poderá ser considerado moeda aquilo que o Direito disser que é; (iii) ser aceito de forma universal pela sociedade, ou seja, a moeda é o instrumento ordinário de efetivação do pagamento e correspondente extinção da relação obrigacional; (iv) representar sempre uma unidade ideal de medida, representativa de valores dos bens e serviços existentes no mercado; e (v) ser o instrumento utilizado por toda a sociedade como elemento de extinção das relações de caráter pecuniário.

À luz dessas considerações, infere-se, sem grandes dificuldades, que o termo "precatório", mesmo que dotado de poder liberatório, não guarda qualquer semelhança com o termo "moeda", pois além de seu poder liberatório não estar inserido no Sistema Monetário Nacional, não é ele um bem fungível de aceitação universal pela sociedade, como também não é o instrumento utilizado por toda a sociedade como elemento de extinção das relações de caráter pecuniário.

Assim, o "precatório" não pode ser tido como termo sinônimo ou equivalente de "moeda", tomada esta em seu sentido jurídico. Por essa razão, o termo "pagamento" referido no artigo 78, $\S 2^{\circ}$ do $\mathrm{ADCT}$ não é aquele do artigo 156, inciso I do Código Tributário Nacional.

${ }^{172}$ Cf. MOSQUERA, Roberto Quiroga. Direito monetário e tributação da moeda. São Paulo: Dialética, 2006. p. 58-59. 
Aliás, o já Superior Tribunal de Justiça decidiu de modo definitivo essa questão, ao apreciar a natureza do precatório como garantia em execução fiscal ${ }^{173}$, no julgamento do Recurso Especial $\mathrm{n}^{\circ} 1.090 .898 / \mathrm{SP}^{174}$, escolhido como representativo da controvérsia e julgado nos temos do artigo 543-C do Código de Processo Civil (repetitivo). Deste julgado, destaca-se o seguinte excerto: “A penhora de precatório é possível, mas não como penhora de dinheiro, e sim como penhora de crédito, que figura na última posição da lista fixada no art. 11 da LEF" ${ }^{\prime 75}$. Logo, também para o Superior Tribunal de Justiça, precatório não é equiparável à moeda.

Disso se conclui que o "precatório" não pode ser considerado "moeda" para fins de extinção do crédito tributário pelo pagamento, nos termos do artigo 156, inciso I do Código Tributário Nacional, sendo juridicamente insustentável a sua utilização como instrumento de pagamento ${ }^{176}$.

Por outro lado, como já defendido alhures, o poder liberatório para pagamento de tributos conferido aos precatórios pelo artigo 78, $\S 2^{\circ}$ do ADCT teria a finalidade de possibilitar que estes precatórios fossem utilizados em procedimento de compensação tributária, modalidade de extinção do crédito tributário prevista no artigo 156, inciso II do Código Tributário Nacional. É o que será exposto a seguir.

\subsection{O precatório e a compensação tributária}

No tópico precedente, restou deduzido que o precatório não é meio idôneo à extinção de créditos tributários pelo pagamento, uma vez que o termo "pagamento" é utilizado pelo artigo 156, inciso I do Código Tributário Nacional em seu sentido estrito, correspondente à entrega de dinheiro (moeda) pelo sujeito passivo aos cofres públicos, ante

\footnotetext{
${ }^{173} \mathrm{O}$ estudo dos precatórios como garantia da execução será realizado de forma mais detalhada adiante.

${ }^{174}$ REsp 1.090.898/SP, Rel. Ministro Castro Meira, Primeira Seção, julgado em 12/08/2009, DJe 31/08/2009.

${ }^{175}$ Apontou-se que o Superior Tribunal de Justiça teria decidido a matéria em definitivo porque o Supremo Tribunal Federal já decidiu, em suas duas Turmas, que a discussão sobre a viabilidade de caução prestada por precatório em execução fiscal tem índole infraconstitucional, e eventual ofensa à Constituição da República se daria de modo reflexo ou indireto (AI 846268 AgR, Relatora Ministra Cármen Lúcia, Primeira Turma, DJe- 17-08-2011 e AI 692.326-AgR, Relator Ministro Joaquim Barbosa, Segunda Turma, DJ 03/03/2011).

176 Poder-se-ia pensar em hipótese de dação em pagamento, mas essa modalidade encontraria as mesmas restrições apontadas para a compensação, especificamente a exigência de lei a regulamentando. Caso semelhante a esse já foi disciplinado pela Lei n. 4.3257/64 às Obrigações Reajustáveis do Tesouro Nacional para o pagamento de tributos federais, após o decurso do prazo de 30 dias para seu resgate.
} 
a natureza pecuniária da relação obrigacional de índole tributária, bem como que o precatório não é equiparável à moeda.

Por essas razões, inferiu-se que o caminho mais adequado seria o uso de precatórios em procedimento de compensação tributária.

Desse modo, para que seja possível confirmar a premissa acima lançada, de que seria viável a extinção de um crédito tributário por meio de uma compensação, consoante determina o artigo 156, inciso II do Código Tributário Nacional, mostra-se necessário o estudo da compensação de créditos tributários com precatórios, o que será realizado, com vistas a facilitar a compreensão do tema, em três situações distintas.

De início, a compensação será estudada levando-se em consideração a ausência de qualquer previsão constitucional atribuindo poder liberatório aos precatórios para o pagamento de tributos, em seguida, analisar-se-á a compensação à luz artigo $78, \S 2^{\circ}$ do Ato das Disposições Constitucionais Transitórias, especificamente para se determinar se essa compensação dispensaria a exigência de lei específica, nos termos do artigo 170 do Código Tributário Nacional e, ao final, a matéria será estudada a partir do artigo 97, § 10, inciso II, também do ADCT, tendo em vista as recentes alterações promovidas pela Emenda Constitucional n ${ }^{\circ} 62 / 2009^{177}$. É o que se passa a fazer.

\subsubsection{A compensação entre créditos tributários e precatórios que não sejam} constitucionalmente dotados de poder liberatório para o pagamento de tributos

Pergunta-se: é possível a utilização de precatórios com a finalidade de extinguir créditos tributários, mesmo que a tais precatórios a não se tenha atribuído constitucionalmente o poder liberatório para o pagamento de tributos?

A resposta é afirmativa.

\footnotetext{
${ }^{177}$ A compensação 100, $\S 9^{\circ}$ da Constituição Federal será objeto de estudo em tópico próprio, uma vez que nessa modalidade de compensação será realizada de acordo com o interesse da Fazenda Pública. A situação é oposta à desenvolvida neste tópico.
} 
Com efeito, contatou-se acima que a compensação em matéria tributária é restrita, exigindo-se, para sua efetivação, que esteja todo o procedimento regulamentado por legislação específica, nos termos do artigo 170 do Código Tributário Nacional.

Inferiu-se ainda que a compensação tributária é intrinsecamente ligada à repetição do indébito tributário, pois nessa hipótese há o perfeito encontro entre os elementos das relações obrigacionais que são contrapostas, principalmente entre os objetos das prestações - ambas terão como objeto um crédito tributário, havendo, tão somente, a inversão dos sujeitos envolvidos.

Inobstante isso, deduziu-se que o ordenamento jurídico não restringe a compensação tributária ao indébito tributário, demonstrando-se que por vezes há até a obrigatoriedade de que seja disciplinada por lei a compensação entre um crédito tributário com outro que não decorra de um indébito tributário, a exemplo da regra nãocumulatividade para o ICMS.

Diante disso, pode-se concluir que nada obsta seja editada lei permitindo a compensação de precatórios com créditos tributários, mesmo que não sejam estes precatórios constitucionalmente dotados de poder liberatório para o pagamento de tributos.

Nessa hipótese, o poder liberatório decorreria da própria lei local, que preveria os requisitos necessários para que o credor do precatório fosse "liberado" da relação jurídicotributária, extinguindo-se o crédito tributário pela compensação.

De todo modo, é novamente importante frisar que sempre que se pretenda realizar uma compensação envolvendo um crédito tributário, faz-se necessária a edição de lei específica de cada ente federado que, no caso dos precatórios, deverá ser ao mesmo tempo o devedor do precatório e o detentor da competência tributária para a instituição do tributo que será extinto por meio da compensação.

Por isso, eventual lei que discipline a compensação entre créditos tributários e precatórios deverá prever, dentre outras coisas, necessariamente, as condições para a efetivação do encontro de contas, o modo pelo qual se desenvolverá o procedimento de compensação em âmbito administrativo, quais serão os créditos passiveis de serem compensados, além, é claro, de estabelecer a maneira pela qual seriam realizados os repasses decorrentes das vinculações constitucionais. 
Corrobora esse entendimento a Lei $\mathrm{n}^{\circ} 10.339$, editada pelo Estado de São Paulo em 3 de julho de $1999^{178}$, que, regulamentando o artigo 170 do Código Tributário Nacional, permitiu a compensação de créditos tributários inscritos na dívida ativa do Estado de São Paulo com precatórios (os quais não eram dotados constitucionalmente de poder liberatório para pagamento de tributos).

A referida lei estadual, de vigência temporária, apresentava a seguinte redação ${ }^{179}$ :

Artigo $1^{\circ}$ - Fica o Poder Executivo autorizado a aceitar a compensação de débitos inscritos na Dívida Ativa e ajuizados até 31 de dezembro de 1998, inclusive, com créditos contra a Fazenda do Estado e suas autarquias, oriundos de sentenças judiciais, com precatórios pendentes de pagamento, até o exercício de competência 1998.

Parágrafo único - Para os efeitos desta lei, entende-se por:

1. crédito contra a Fazenda do Estado os valores devidos por força de sentença judicial, transitada em julgado, constante do respectivo precatório, expedido, processado e registrado pelo Tribunal competente, a respeito do qual não penda defesa ou recurso judicial;

2. crédito contra as autarquias os valores devidos por força de sentença judicial, transitada em julgado, constante do respectivo precatório, expedido, processado e registrado pelo Tribunal competente, a respeito do qual não se penda defesa ou recurso judicial, e cuja assunção pela Fazenda do Estado, mediante transferência pela autarquia responsável, fica autorizada, desde que para os fins previstos neste artigo;

3. débito inscrito na Dívida Ativa e ajuizado aquele de natureza tributária ou não-tributária, a respeito do qual não penda defesa ou recurso judicial.

Artigo $2^{\circ}$ - A compensação fica restrita aos requerimentos protocolizados no prazo de 180 (cento e oitenta) dias, a partir da regulamentação desta lei.

Parágrafo único - $\mathrm{O}$ requerimento sujeita-se a exame prévio pela Procuradoria Geral do Estado, que poderá fundamentadamente indeferi-lo.

Artigo $3^{\circ}$ - A extinção dos débitos realizada na forma prevista no artigo $1^{\circ}$ não dispensa o pagamento prévio, em dinheiro, das despesas processuais.

Artigo $4^{\circ}$ - Para os fins desta lei os honorários advocatícios incidentes sobre os débitos liquidandos serão reduzidos para no máximo $5 \%$ (cinco por cento).

Artigo $5^{\circ}$ - O Poder Executivo regulamentará esta lei no prazo de 30 (trinta) dias, contados da data de sua publicação.

Artigo $6^{\circ}$ - Esta lei entrará em vigor na data de sua publicação.

Sem que se atenha a todos os seus comandos, da simples leitura dos artigos $1^{\circ}$ e $2^{\circ}$ da lei estadual acima transcrita, depreendem-se as condições para que os contribuintes pudessem compensar seus débitos tributários com precatórios judiciais, a saber:

\footnotetext{
${ }^{178}$ A Lei $n^{\circ} 10.339 / 99$ do Estado de São Paulo foi questionada por meio da ADI $n^{\circ} 2.927$, a qual foi extinta sem julgamento de mérito, em razão do exaurimento da eficácia jurídico-normativa da lei paulista (ADI 2927, Relator Min. Dias Toffoli, DJe 11/02/2010).

${ }^{179}$ Pede-se licença para transcrever a lei na íntegra, em virtude de sua especialidade e da sua importância para o desenvolvimento do pensamento.
} 
(i) eram passíveis de compensação apenas os créditos tributários inscritos na dívida ativa do Estado de São Paulo;

(ii) desde que a inscrição dos débitos em dívida ativa e o ajuizamento da execução fiscal tivessem ocorrido até 31 de dezembro de 1998;

(iii) os precatórios passíveis de compensação eram apenas aqueles pendentes de pagamento até o exercício de competência 1998;

(iv) tanto sobre os precatórios quanto sobre os créditos tributários não poderia haver questionamento jurídico, seja no âmbito administrativo ou judicial; e

(v) a compensação deveria ser requerida à Administração Tributária no prazo de 180 dias, contados da regulamentação da citada lei estadual; estando o procedimento sujeito ao exame prévio do requerimento pela Procuradoria Geral do Estado, que poderia indeferi-lo, fundamentadamente.

A regulamentação da mencionada lei estadual deu-se pelo Decreto $n^{\circ} 44.075 / 99$, publicado no dia 3 de julho de 1999, que além de disciplinar a execução da Lei Estadual ${ }^{\circ}$ 10.339/99, determinou que a Procuradoria Geral do Estado de São Paulo editasse resolução para o cumprimento do próprio Decreto 44.075/99. Editou-se, assim, a Resolução PGE ${ }^{\circ}$ $357 / 99$.

Diante dessas considerações, conclui-se que nada impede que seja editada lei viabilizando a realização de compensação entre créditos tributários e precatórios, ainda que a estes não seja constitucionalmente atribuído poder liberatório para o pagamento de tributos, bastando que haja lei do ente federado detentor do precatório assim permitindo.

Mais do que isso, compreende-se que a atribuição de poder liberatório aos precatórios para o pagamento de tributos é apenas um dos requisitos para que seja possível a realização da compensação destes com créditos tributários, exigindo-se estejam previstos em lei os demais ${ }^{180}$.

Com suporte nessas conclusões, passa-se ao estudo da compensação fundada no artigo 78, $\S 2^{\circ}$ do Ato das Disposições Constitucionais Transitórias.

\footnotetext{
${ }^{180}$ Nesse sentido é a decisão monocrática do Ministro do Supremo Tribunal Cezar Peluso, consignando que "Todo e qualquer crédito do sujeito passivo contra a Fazenda Pública pode ser objeto de compensação, desde que líquido e certo, vencido ou vincendo, bastando para tanto previsão legal a lhe dar poder liberatório. O precatório representa um crédito líquido e certo do particular contra o Estado." (RE 538323/RS, DJe 18/02/2010).
} 


\subsubsection{A compensação com fundamento no artigo $78, \S 2^{\circ}$ do Ato das Disposições Constitucionais Transitórias}

Infere-se das conclusões acima que é possível a realização de compensação entre de precatórios e créditos tributários, bastando haja lei específica nesse sentido, consoante exigência do artigo 170 do Código Tributário Nacional.

De outro lado, no capítulo anterior, depreendeu-se que o objetivo do artigo $78, \S 2^{\circ}$ do Ato das Disposições Constitucionais Transitórias ${ }^{181}$, ao conferir poder liberatório para pagamento de tributos aos precatórios parcelados, era instituir uma solução de mercado para saldar o estoque da dívida existente, principalmente pela utilização de precatórios em compensações tributárias.

Entretanto, resta definir questão de fundamental importância, a saber: diante da previsão do artigo 78, $\S 2^{\circ}$ do $\mathrm{ADCT}$ haveria necessidade de edição de lei infraconstitucional regulamentando a compensação, nos termos do artigo 170 do Código Tributário Nacional, ou seria o citado dispositivo constitucional auto-aplicável, dispensando a regulamentação legal da compensação?

Sobre essa questão, existem duas grandes correntes de pensamento.

A primeira, consolidada pelas turmas que julgam a matéria tributária no Superior Tribunal de Justiça, é a de que a declaração do direito à compensação tributária pressupõe a existência de lei que a autorize, oriunda da pessoa jurídica de Direito Público competente para a instituição do tributo, ainda que para os fins do artigo $78, \S 2^{\circ}$, do $\operatorname{ADCT}^{182}$.

${ }^{181}$ Apesar de o artigo 78 do ADCT estar com a sua eficácia suspensa por força da medida cautelar deferida pelo Supremo Tribunal Federal nos autos da ADI 356, conforme alhures exposto, e de também ter havido a revogação tácita do dispositivo pelo artigo 97 do ADCT, a sua análise é ainda extremamente relevante, a uma porque a Emenda Constitucional n 62/2009 que inseriu o artigo 97 no ADCT é objeto de ADI no Supremo Tribunal Federal, como visto acima, e, a duas, porque o próprio Supremo Tribunal Federal julgará recursos extraordinários com repercussão geral reconhecida envolvendo o artigo $78, \S 2^{\circ}$ do ADCT, como o RE 566.349 e o RE 597.092. Assim, as questões envolvendo o artigo 78 do ADC não estão definidas.

${ }^{182}$ No Supremo Tribunal Federal a discussão sobre o tema encontra-se suspensa, uma vez que, depois de reconhecida, nos autos do $\mathrm{RE} \mathrm{n}^{\circ} 566.349 / \mathrm{MG}$, a repercussão geral sobre a "aplicabilidade imediata do art. $78, \S 2^{\circ}$, do ADCT para fins de compensação de débitos tributários com precatórios de natureza alimentar", a Corte vem sobrestando o julgamento dos recursos, e devolvendo aos tribunais de origem todos os processos cuja discussão gravite em torno desse tema. Nesse sentido são os seguintes precedentes: ARE 665799, Relator Ministro Joaquim Barbosa, DJe- 29/10/2012; AI 833872 ED, Relatora 
Isso porque, a jurisprudência da Corte Superior consolidou o entendimento de que "a compensação em matéria tributária não se opera automaticamente, exige-se para sua implementação a autorização em lei e a observância das demais disposições da legislação tributária quanto às condições e limites por ela admitidos (art. 170 do CTN)"'183.

Nesse sentido, transcrevem-se as seguintes ementas ${ }^{184}$ :

TRIBUTÁRIO. AGRAVO REGIMENTAL NO AGRAVO DE INSTRUMENTO. DÉBITOS TRIBUTÁRIOS. COMPENSAÇÃO COM CRÉDITOS DE PRECATÓRIOS. MEDIDA QUE RECLAMA A EXISTÊNCIA DE LEI LOCAL AUTORIZADORA. ENTENDIMENTO PACÍFICO NO ÂMBITO DO SUPERIOR TRIBUNAL DE JUSTIÇA. AGRAVO NÃO PROVIDO.

1. "A jurisprudência pacificada desta Corte considera que a compensação de tributos depende da existência de lei autorizativa editada pelo respectivo ente federativo" [...]

(AgRg no AREsp 120.392/RS, Rel. Ministro Arnaldo Esteves Lima, Primeira Turma, julgado em 04/09/2012, DJe 11/09/2012)

TRIBUTÁRIO. PRECATÓRIO. PARANÁ. ICMS. IPVA. COMPENSAÇÃO. DECRETO 418/2007.

1. Compete à legislação de cada ente federativo estabelecer o regramento da compensação relativa a seus tributos, ainda que para fins do art. $78, \S 2^{\circ}$, do ADCT, de forma que são legítimas as restrições do Decreto 418/2007 do Estado do Paraná. Precedentes do STJ.[...]

(AgRg no RMS 34.980/PR, Rel. Ministro Herman Benjamin, Segunda Turma, DJe $17 / 10 / 2011)$

A segunda corrente, que é prevalecente na doutrina, defende que os citados dispositivos constitucionais prescindem de regulamentação infraconstitucional. É a posição de Luís Eduardo Schoueri ${ }^{185}$ :

Uma relevante exceção deve ser mencionada em virtude do disposto no artigo 78 do Ato das Disposições Constitucionais Transitórias. Por meio daquele dispositivo, autorizou-se que os precatórios, excetuados os de pequeno valor e os de natureza alimentícia, fossem parcelados em 10 parcelas anuais e sucessivas. Prevendo o constituinte a possibilidade de que ainda assim não fossem honradas aquelas parcelas, o referido dispositivo autorizou: (i) que os créditos de tais

Ministra Rosa Weber, Primeira Turma, DJe 16-10-2012; ARE 710128, Relator Ministro Celso de Mello, DJe 18/10/2012; e ARE 696250, Relator Min. Dias Toffoli, DJe 08/10/2012.

${ }^{183}$ AgRg no AREsp 115.109/RS, Rel. Ministro HUMBERTO MARTINS, SEGUNDA TURMA, julgado em 17/05/2012, DJe 25/05/2012.

${ }^{184}$ Precedentes na mesma linha: AgRg no RMS 35.365/PR, Segunda Turma, Rel. Min. Castro Meira, DJe 10/5/12; AgRg no REsp 1238247/RS, Rel. Ministro Arnaldo Esteves Lima, Primeira Turma, julgado em 05/06/2012, DJe 13/06/2012; AgRgno Ag 1228671/PR, Rel. Ministra Eliana Calmon,Segunda Turma, DJe 03/05/2010; EDcl no AgRgnoREsp 1157869/RS, Rel. Ministro Luiz Fux, Primeira Turma, DJe 16/08/2010; AgRg no Ag 1207543/PR, Rel. Ministro Benedito Gonçalves, Primeira Turma, Dje17/06/2010; AgRg no Ag 1272393/RS, Rel. Ministro Castro Meira,Segunda Turma, julgado em 06/04/2010, DJe 14/04/2010; eAgRg no RMS30.489/PR, Rel. Ministro Hamilton Carvalhido, Primeira Turma, DJe 15/06/2010.

${ }^{185}$ SCHOUERI, Luís Eduardo. Direito tributário. São Paulo: Saraiva, 2011. p. 564. 
precatórios fossem transferidos a terceiros e (ii) as parcelas não honradas até o final do respectivo ano tivessem pode liberatório junto ao Poder Público devedor. Diante de tal dispositivo com força constitucional, é de se concluir que os créditos de precatórios incluídos naquele dispositivo podem ser compensados contra débitos junto ao Poder Público, independentemente de autorização legal.

\section{No mesmo sentido é o entendimento de Fernando Facury Scaff ${ }^{186}$, para quem:}

Deve ser aplicada a norma constitucional em sua plenitude, não cabendo aguardar lei infraconstitucional para sua plena eficácia. A Constituição deve prevalecer sobre a legislação ordinária, ou mesmo sua ausência, no caso de normas que possuam plena eficácia, como a do art. 78 , parágrafo $2^{\circ}$, do ADCT.

\section{Compartilha desse entendimento Paulo Roberto Lyrio Pimenta ${ }^{187}$ :}

Na hipótese em estudo, o parágrafo $2^{\circ}$ do art. 78 do ADCT diz expressamente que as prestações anuais devidas pelo Poder Público como crédito de precatório judicial, inadimplidos até o final do exercício a que se referem, terão, "poder liberatório" do pagamento de tributos da entidade devedora , autorizando, como salientado anteriormente, a compensação de duas dívidas de dinheiro, fungíveis, portanto.

Como nesse caso a como nesse caso a compensação foi diretamente no texto constitucional, por meio de norma de eficácia plena e de aplicabilidade imediata, vale reafirmar, não depende de edição de lei do ente federado para ser efetivada. Isso significa que a previsão do art. 170 do CTN é inaplicável à hipótese do art. 78 , parágrafo $2^{\circ}$, do ADCT, pois uma norma infraconstitucional não pode retirar ou reduzir a eficácia e aplicação de norma constitucional. Entendimento contrário importa em burla ao princípio da supremacia da Constituição ${ }^{188}$.

\section{Também nessa trilha, Sacha Calmon Navarro Côelho Navarro e Misabel Abreu}

Machado Derzi ${ }^{189}$ :

não há nenhuma cláusula geral de compensação no texto constitucional. Via de regra - e por força da norma geral de Direito Tributário (art. 170 do CTN) - a compensação depende de lei autorizadora. Pode-se extrair diretamente do Texto Constitucional, isto sim, a submissão do Estado à jurisdição e sua obrigação de efetivamente cumprir as condenações, restituindo valores indevidamente recebidos, o que se faz pelo sistema de precatório. Assim, na hipótese em que a restituição de indébito tributário não é efetiva, em face do não-pagamento de

186 SCAFF, Fernando Facury. O uso de precatórios para pagamento de tributos. In: ROCHA, Valdir de Oliveira (coord.). Grandes questões atuais de direito tributário. v. 13. São Paulo: Dialética, 2009.. p.116.

187 PIMENTA, Paulo Roberto Lyrio. O Pagamento de Tributos por meio de créditos relativos aos precatórios judiciais. Revista dialética de direito tributário, São Paulo, n. 177, 2010. p. 127.

${ }^{188}$ Para o citado autor, seria dispensável lei também na hipótese de o precatório se utilizado para pagamento de tributos, confira-se: "No caso em exame, pode-se construir a seguinte norma com base no enunciado do art. 78, parágrafo $2^{\circ}$, do ADCT: se o Poder Público não efetuar o pagamento das prestações anuais do precatório até o final do exercício a que se referem, então deve ser a permissão para o credor do Estado utilizar o valor relativo ao montante inadimplido para o pagamento de tributos. Essa norma não depende do auxílio de nenhuma outra para atuar, vale dizer, possui eficácia plena e aplicabilidade imediata, outorgando ao contribuinte uma situação subjetiva de vantagem em face do Poder Público, ou seja, um direito subjetivo."(PIMENTA, Paulo Roberto Lyrio. O Pagamento de Tributos por meio de créditos relativos aos precatórios judiciais. Revista dialética de direito tributário, São Paulo, n. 177, 2010. p. 126).

189 CÔELHO, Sacha Calmon Navarro; DERZI, Misabel Abreu Machado. Precatórios, tributos e a emenda constitucional $n^{\circ}$ 62/2009. Revista dialética de direito tributário, São Paulo, n. 180, 2010. p. 18. 
precatórios (como ocorre com vários Estados e Municípios), abre-se a possibilidade para que seja buscado diretamente no Texto Constitucional o fundamento para a compensação, de modo a impedir que haja uma ruptura dos pilares do Estado de Direito. Os fundamentos serão, justamente, o acesso à jurisdição e o princípio do Estado de Direito. Efetivamente, não efetuado o pagamento, tem o Judiciário de encontrar outro modo de dar cumprimento às suas decisões, satisfazendo o credor. A garantia de acesso à jurisdição tem de ser efetiva, mesmo contra o Estado.

\section{Em igual direção, Hugo de Brito Machado ${ }^{190}$ :}

o direito do contribuinte à compensação tem inegável fundamento na Constituição. Isto quer dizer que nenhuma norma inferior pode, validamente, negar esse direito, seja diretamente, seja por via oblíqua, tornando impraticável o seu exercício. Assim, a questão de saber se o direito à compensação tem, ou não, fundamento constitucional, é em outras palavras a questão de saber se valem as normas jurídicas inferiores que de algum modo inviabilizam a compensação.

O direito de compensar é decorrência natural da garantia dos direitos de crédito, que consubstanciam parcelas do direito de propriedade, combinada com outros preceitos constitucionais. Seria absurdo pretender que alguém, sendo credor e, também, devedor da mesma pessoa, pudesse exigir daquela o pagamento de seu crédito, sem que estivesse também obrigado a pagar o seu débito. A compensação é, na verdade, um efeito inexorável das obrigações jurídicas, e desse contesto não se pode excluir a Fazenda Pública.

Exige-se, portanto, seja tomada uma posição.

$\mathrm{O}$ entendimento que mais se mostra coerente às premissas já fixadas e consentâneo ao que até agora se deduziu da legislação de regência, é o da indispensabilidade de lei regulamentando a compensação tributária em qualquer situação, mesmo nos casos do artigo $78, \S 2^{\circ}$ do ADCT.

Esse ponto de vista leva em consideração o fato de que a compensação em matéria tributária é diferente da compensação no direito privado. Em Direito Tributário, como visto acima, não há que se falar em direito subjetivo à compensação, antes, esta decorre da discricionariedade de cada detentor de competência tributária.

É o que se depreende das lições de Aliomar Baleeiro ${ }^{191}$ :

O CTN, art. 170, acolheu a compensação 'nas condições e sob as garantias que estipula' a lei ou que a ela cometer à estipulação da autoridade em caso concreto. $[\ldots]$

A compensação dos Códigos Civil e Comercial é modalidade de pagamento compulsório ou de extinção compulsória da dívida. No sentido de que o devedor pode forçar o credor a aceitá-la, retendo o pagamento ou lhe opondo como defesa o próprio crédito à ação de cobrança caso intentada.

No direito fiscal, a compensação é condicionada ao discricionarismo do Tesouro Público.

Mas o sujeito passivo só poderá contrapor seu crédito ao crédito tributário, como direito subjetivo seu, nas condições e sob as garantias que a lei fixar. Fora disso, quando a lei o permite, se aceitar as condições específicas que a autoridade

${ }^{190}$ MACHADO, Hugo de Brito. Curso de direito tributário. 31. ed. São Paulo: Malheiros, 2010. p. 224.

${ }^{191}$ BALEEIRO, Aliomar. Curso de direito tributário brasileiro. 9. ed. São Paulo: Forense, 1995. 
investida de poder discricionário, nos limites legais, para fixá-las, estipular, julgando da conveniência e da oportunidade de aceitar ou recusar o encontro de débitos.

E o simples fato de o artigo $78, \S 2^{\circ}$ do ADCT conferir aos valores das parcelas relativas aos precatórios inadimplidos poder liberatório para o pagamento de tributos não é o bastante para que se dispense a edição de lei regulamentando a matéria, como exige o artigo 170 do Código Tributário Nacional.

Isso porque o poder liberatório é apenas um dos requisitos necessários à realização da compensação em tela, porém, os demais elementos indispensáveis devem estar previamente disciplinados em lei, sem a qual sequer é possível se operacionalizar a compensação.

A imposição de que haja lei para que se efetive uma compensação tributária não é mera exigência formal, uma vez que só a lei poderá contemplar todos os requisitos imprescindíveis à compensação entre precatórios e créditos tributários.

Com efeito, caberia a lei tratar do momento em que o crédito tributário poderia ser considerado extinto, em razão da regra constitucional de obrigatória observação da ordem cronológica para o pagamento dos precatórios. Haveria ainda a exigência de lei para que fossem regulamentados diversos outros fatores, como o modo pelo qual seriam asseguradas as vinculações da receita do tributo que deixou de ser arrecadado em virtude da compensação efetivada, além de estabelecer quais seriam os créditos abrangidos no procedimento, os documentos que comprovariam a existência do débito e do crédito, principalmente nos casos de cessão de créditos, a natureza do crédito do precatórios, eventuais preferências etc.

Por esses motivos, pode-se afirmar que o artigo $78, \S 2^{\circ}$ do ADCT não é norma constitucional de eficácia plena, vez que depende de outra norma para a sua regular produção de efeitos.

Perceba-se que não se está negando eficácia ao dispositivo constitucional, pois é incontroverso que todas as normas constitucionais possuem eficácia, ainda que mínima.

De fato o que se constata é que, diante da necessidade de edição de lei regulamentando o citado dispositivo constitucional para que sejam produzidos seus regulares efeitos, não como há se sustentar, como defendem os autores acima citados, que a norma constitucional em análise teria eficácia plena, a ponto de dispensar qualquer regulamentação em sede infraconstitucional. 
Corrobora esse entendimento a doutrina de José Afonso da Silva ${ }^{192}$ :

Temos que partir, aqui, daquela premissa já tantas vezes anunciada: não há norma constitucional alguma destituída de eficácia. Todas elas irradiam efeitos jurídicos, importando sempre uma inovação da ordem jurídica preexistente à entrada em vigor da constituição a que aderem e a nova ordenação instaurada. $\mathrm{O}$ que se pode admitir é que a eficácia de certas normas constitucionais não se manifesta na plenitude de seus efeitos jurídicos pretendidos pelo constituinte enquanto não se emitir uma normação jurídica ordinária ou complementar executória, prevista ou requerida.

Ainda com suporte nos ensinamentos de José Afonso da Silva ${ }^{193}$, pode-se concluir tratar-se a norma do artigo $78, \S 2^{\circ}$ do ADCT de uma norma constitucional de eficácia limitada, confira-se:

pode-se dizer que as normas de eficácia plena sem a de aplicabilidade direta, imediata e integral sobre os interesses objeto de sua regulamentação jurídica, enquanto as normas de eficácia limitada são de aplicabilidade indireta, mediata e reduzida, porque somente incidem totalmente sobre esses interesses após uma normatividade ulterior que lhes desenvolva a eficácia, conquanto tenham uma incidência reduzida e surtam outros efeitos não-essenciais, ou melhor, não dirigidos aos valores-fins da norma, mas apenas a certos valores $\mathrm{e}$ condicionantes, como melhor se esclarecerá depois.

Estabelecido que o artigo $78, \S 2^{\circ}$ do ADCT não é autoaplicável, passa-se a demonstrar, com mais detalhes, os requisitos que necessariamente devem estar previstos na lei específica que vier a ser editada pelo ente federado devedor do precatório para que se viabilize a compensação destes com créditos tributários, de modo a afastar qualquer dúvida acerca da imprescindibilidade da lei na hipótese em comento.

O primeiro óbice que se coloca à realização de compensação entre precatórios e créditos tributários é a exigência do artigo 100 da Constituição Federal de que os precatórios sejam liquidados de acordo com a ordem cronológica de apresentação destes.

Isso porque, realizada uma compensação em momento anterior ao que deveria ser pago o precatório, o credor deste precatório se valerá do crédito nele representado antes de outros credores que aguardavam na fila de pagamento, decorrendo daí a quebra da ordem cronológica de pagamento dos precatórios, com as consequências dela decorrentes, como a possibilidade de determinação de sequestro.

\footnotetext{
${ }^{192}$ SILVA, José Afonso da. Aplicabilidade das normas constitucionais. 7. ed., São Paulo: Malheiros, 2007. p. 81-82.

${ }^{193}$ Ibidem. p. 83.
} 
Como solução, poder-se-ia pensar no "congelamento de valores" no momento exato do encontro de contas, operando-se de imediato os efeitos da compensação para o devedor do tributo, aguardando-se, de outro lado, o pagamento do precatório de acordo com a ordem cronológica constitucionalmente exigida.

Na prática haveria uma compensação sob condição resolutória, de modo que assim que quitado o precatório, na sua regular ordem cronológica, ato contínuo, se efetivaria o recolhimento do tributo, extinguindo-se o crédito tributário que havia sido compensado, retirando-se, por conseguinte, a condição que pendia sobre a compensação.

Tal expediente já foi adotado no Estado de São Paulo pela citada Lei Estadual $n^{\circ}$ 10.339/99. É esse também o modelo de compensação regulamentado pelo Conselho Nacional de Justiça, Resolução CNJ n 115/2010, e pela Lei $n^{\circ} 12.431 / 2011$, para as compensações do artigo 100, $\S 9^{\circ}$, o que será estudado a seguir.

Referido modelo, entretanto, enfrenta uma dura crítica, especificamente no que se refere à repartição das receitas tributárias constitucionalmente exigida, como, por exemplo, a vinculação de $50 \%$ sobre a arrecadação de IPVA que os Estados devem repassar aos Municípios (artigo 158, inciso III da Constituição Federal).

Uma solução simples para essa crítica seria considerar como valor "arrecadado" o que representasse efetivo ingresso de receita nos cofres públicos. Assim, o repasse seria obrigatório, na situação acima descrita, apenas no momento do pagamento do precatório, dentro da ordem cronológica constitucionalmente exigida.

No entanto, tal solução encontra outras dificuldades, uma delas decorre do fato de que os precatórios e os créditos tributários são atualizados por índices diferentes: aqueles são atualizados pelo índice oficial de remuneração básica da caderneta de poupança, já estes podem sofrer atualização diária, como o ICMS no Estado de São Paulo.

Dessa maneira, uma transferência "congelada" representaria, considerando-se a atualização do crédito tributário pelo índice de remuneração da caderneta de poupança, significativo decréscimo no valor efetivamente repassado pelos Estados aos Municípios.

Outro impeditivo seria uma possível alegação dos Municípios de que o Estado estaria retendo indevidamente, por seu exclusivo interesse, valores que constitucionalmente deveriam lhe deveriam ser repassados de imediato. 
Para ilustrar o quão significativo são as vinculações das receitas da arrecadação de impostos $^{194}$ para o Estado de São Paulo, por exemplo, cola-se o quadro abaixo, onde se constata, com maior facilidade, o quanto do valor efetivamente arrecadado é disponibilizado nos cofres estaduais. Para facilitar o exemplo, utilizou-se um recolhimento fictício de R\$1.000,00 a título de ICMS. Confira-se:

\begin{tabular}{|c|c|c|}
\hline (I) Entrada De Recursos & $\begin{array}{c}\text { Receita de } \\
\text { ICMS R\$ } \\
\mathbf{1 . 0 0 0 , 0 0}\end{array}$ & Vinculações (referência legislativa) \\
\hline $\begin{array}{c}\text { (-) Quota-parte dos } \\
\text { municipios }(25,00 \%)\end{array}$ & $(-) 250,00$ & Constituição Federal, art. 158, IV. \\
\hline (-) FUNDEB $(20,00 \%)$ & $(-) 150,00$ & $\begin{array}{c}\text { Emenda Constitucional 53/2006, art. } \\
60 \text { do ADCT e Lei } 11.494 / 2007 .\end{array}$ \\
\hline Valor líquido (relativo ao ICMS arrecadado) & $\mathbf{R \$ \mathbf { 6 0 0 , 0 0 }}$ \\
\hline
\end{tabular}

\begin{tabular}{|c|c|c|}
\hline (II) Outras vinculações & Em reais & Referência legislativa \\
\hline Educação $(30,00 \%)$ & 225,00 & $\begin{array}{l}\text { Constituição Federal artigo } 212 \\
\text { (mínimo de } 25,00 \% \text { ) e Constituição } \\
\text { Estadual, artigo } 225 \text {. }\end{array}$ \\
\hline Dívida com a União $(13,00 \%)$ & 97,50 & $\begin{array}{l}\text { Contrato de Refinanciamento de } \\
\text { Dívidas entre União e Estado } \\
\text { (cláusula } 5^{\circ} \text {, caput e } \S 1^{\circ} \text { ). }\end{array}$ \\
\hline Saúde $(12,00 \%)$ & 90,00 & $\begin{array}{l}\text { EC 29/2000, Constituição Federal } \\
\text { art. } 198 \text { e art. } 77 \text { do ADCT cc/ } \\
\text { Constituição Estadual art. } 222 \\
\text { parágrafo único. }\end{array}$ \\
\hline Universidade $(9,57 \%)$ & 71,78 & 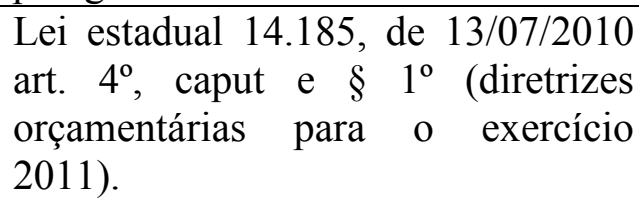 \\
\hline Precatórios $(1,50 \%)$ & 11,25 & $\begin{array}{l}\text { Emenda Constitucional 62/2009, art. } \\
97 \text { do ADCT. }\end{array}$ \\
\hline FAPESP $(1,00 \%)$ & 7,50 & Constituição Estadual art. 271. \\
\hline Cultura $(0,50 \%)$ & 3,75 & $\begin{array}{l}\text { Constituição Estadual art. 263-A } \\
\text { (opcional). }\end{array}$ \\
\hline \multicolumn{2}{|l|}{ Total das outras vinculações } & R\$ 506,78 \\
\hline
\end{tabular}

\footnotetext{
${ }^{194} \mathrm{O}$ termo vinculação de receita será tratado sem o rigor de considerá-la apenas quando há elo jurídico entre fonte e destino da receita. Sobre o tema, confira-se: CARVALHO, André Castro. Vinculação de receitas públicas. São Paulo: Quartier Latin, 2010. p. 117.
} 


\begin{tabular}{|l|l|}
\hline (III) Total vinculado & Em reais \\
\hline Quota-parte dos municípios & 250,00 \\
\hline (+) FUNDEB & 150,00 \\
\hline (+) total das outras vinculações & 506,78 \\
\hline & \\
\hline valor total de receitas vinculadas (ICMS) & $\mathbf{9 0 6 , 7 8}$ \\
\hline
\end{tabular}

\begin{tabular}{|l|l|}
\hline (IV) Valor efetivo de receita de ICMS & $\mathbf{R} \$ \mathbf{1 . 0 0 0 , 0 0}$ (recolhidos) \\
\hline & \\
\hline valor total vinculado & $\mathbf{( - )} 906,78$ \\
\hline subtotal & 93,23 \\
\hline (+) recuperação do FUNDEB & $\mathbf{1 5 0 , 0 0}$ \\
\hline Saldo disponível & $\mathbf{R} \mathbf{2 4 3 , 2 3}$ \\
\hline
\end{tabular}

Logo, para cada R\$ 1.000,00 recolhidos aos cofres do Estado de São Paulo a título de ICMS, principal imposto estadual, apenas $\mathrm{R} \$ 243,23$ podem ser considerados como saldo disponível deste ente federado.

No mesmo exemplo, verifica-se que mais de $70 \%$ do valor total arrecadado é repassado por força das vinculações ${ }^{195}$ constitucionais.

Essas considerações são mais do que suficientes para se afirmar a imprescindibilidade de lei especifica regulamentando a compensação com fundamento no artigo $78, \S 2^{\circ}$ ADCT.

Como o exemplo utilizado foi o do Estado de São Paulo, que é o maior devedor de precatórios do país, abaixo segue também um levantamento sobre o comportamento do Tribunal de Justiça de São Paulo nas ações em que se busca a realização de compensação de créditos de precatórios com tributos, sem que haja lei específica.

Neste primeiro gráfico é relacionada a quantidade de acórdão proferido por cada Câmara de Direito Público do Tribunal de Justiça de São Paulo, citando o posicionamento firmado.

${ }^{195}$ Aqui também não utilizada em sentido técnico. 


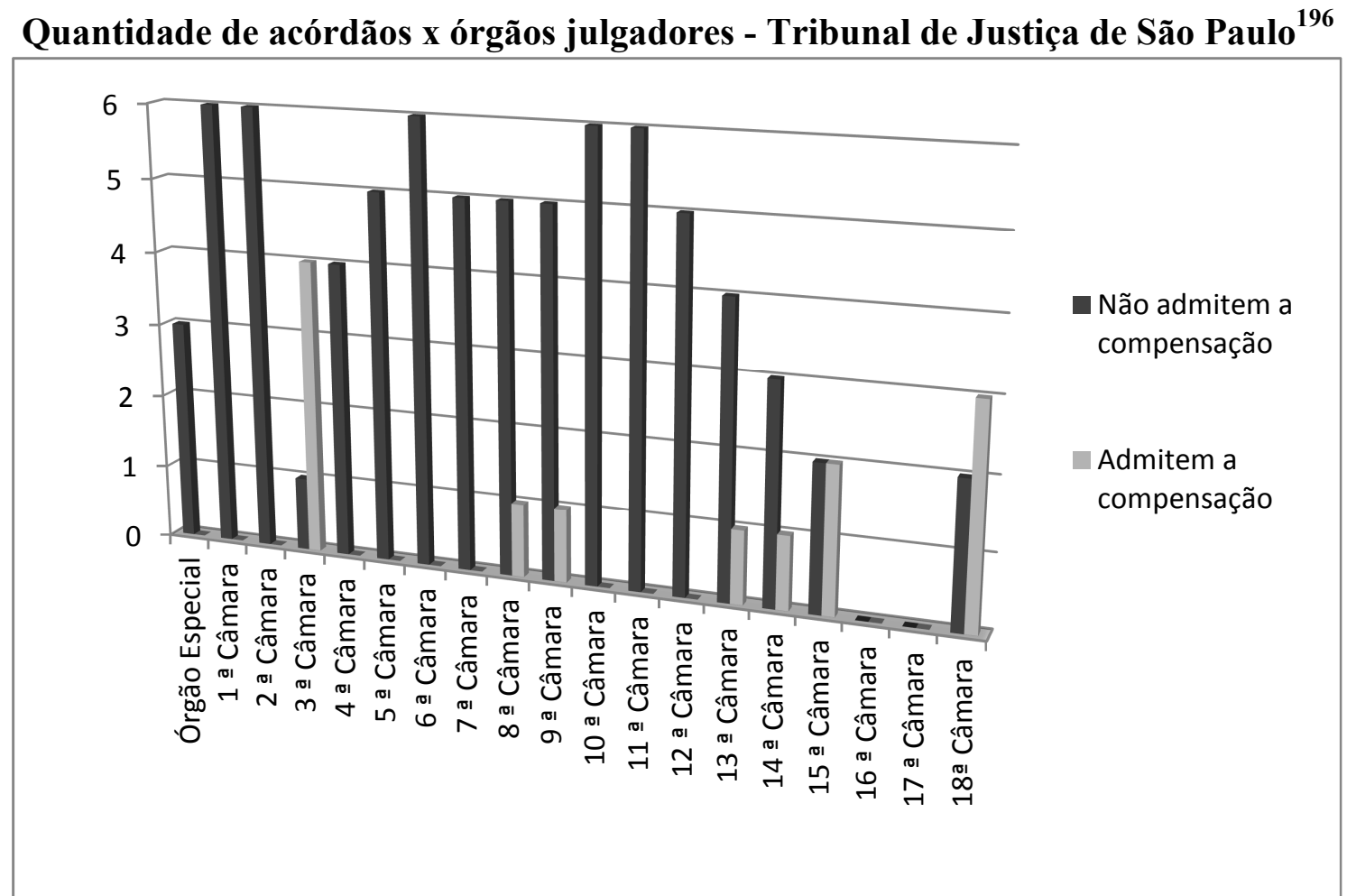

Fonte: o próprio autor.

Já no gráfico abaixo, pode-se constatar que num universo de 84 acórdãos pequisados, apenas 13 reconhecem a possibilidade de compensação de créditos tributários com precatórios, sem que seja editada lei específica. Contudo, chama-se a atenção para o fato de que o Órgão Especial do Tribunal de Justiça já firmou o entendimento no sentido não ser possível a compensação sem lei a autorizando ${ }^{197}$. Desse modo, esse quandro deverá ser alterado em breve.

\footnotetext{
${ }^{196}$ Os acórdãos do Tribunal de Justiça de São Paulo que foram pesquisados encontram-se no anexo.

${ }^{197}$ Confira-se: processo $\mathrm{n}^{\circ}$ 0064705-27.2011.8.26.0000, Órgão Especial, Relator Mário Devienne Ferraz, julgado em 16 de novembro de 2011; processo $\mathrm{n}^{\circ}$ 0074431-25.2011.8.26.0000, Órgão Especial, Relator Samuel Júnior, julgado em 14 de dezembro de 2011 e processo $n^{\circ}$ 0230854-81.2009.8.26.0000, Órgão Especial, Relator A.C. Mathias Coltro, julgado em 02 de março de 2011.
} 


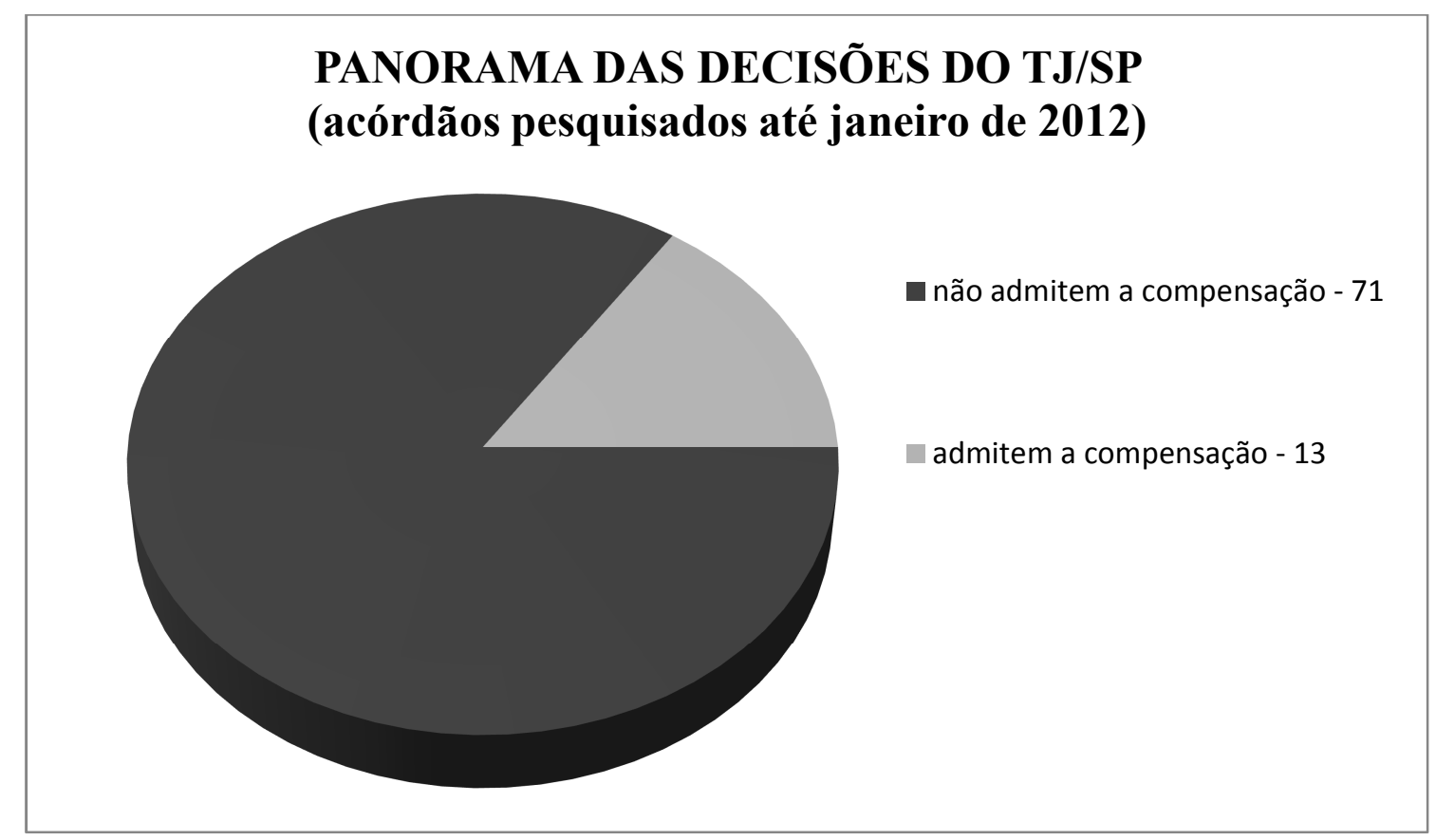

Fonte: o próprio autor

Logo, a exigência de lei, nos termos do artigo 170 do Código Tributário Nacional é inafastável.

Atualmente, como dito acima, não há lei no Estado de São Paulo disciplinado a compensação entre débitos tributários e créditos representados por precatórios.

Há, contudo, diversos projetos de lei tramitando na Assembleia Legislativa do Estado de São Paulo que versam sobre a utilização de precatórios em procedimento de compensação tributária, destacando-se: o PL n ${ }^{\circ}$ 1.297/2009 que dispõe sobre a forma de aquisição de precatório judicial e sua subsequente utilização para compensação de débitos tributários inscritos; o PL n 301/2010 que disciplina a compensação de débitos de IPVA com precatórios; o PL n 303/2010 e o PL n 800/2011 que autoriza, nos termos do artigo 170 do Código Tributário Nacional, a compensação parcial ou total de débitos originários de sentenças judiciais com precatórios pendentes de pagamento contra a Fazenda Pública.

Não há também lei disciplinando a compensação de precatórios com créditos tributários em outros Estados da federação, como o Paraná, o Rio Grande do Sul ${ }^{198}$, Bahia, Espírito Santo, Goiás e o Distrito Federal ${ }^{199}$.

\footnotetext{
${ }^{198}$ No Estado do Rio Grande do Sul já autorizou a compensação por lei, revogando-a, posteriormente (Leis $11.472 / 2000$ e 12.209/2004, respectivamente).

${ }^{199}$ No Distrito Federal já houve lei autorizando a compensação, Lei Complementar nº 52/1997.
} 
Em contrapartida, o Estado do Rio de Janeiro, editou a lei ${ }^{\circ} 5.647 / 2010$ instituindo um programa de parcelamento incentivado de tributos, prevendo a possibilidade de compensação de tributos com precatórios. No artigo 10, a citada lei, com base na EC $n^{\circ}$ $62 / 2009$, estabelece que poderão ser liquidados à vista, mediante a compensação com créditos representados por precatórios judiciais pendentes contra o Estado, suas Autarquias e Fundações, os débitos, tributários ou não, além do saldo remanescente dos débitos consolidados de parcelamentos anteriores, desde que relativos a fatos geradores até $31 / 12 / 2008$.

Ademais, a Lei. 6.136/2011, também do Estado do Rio de Janeiro permite o pagamento, o parcelamento ou a compensação dos débitos inscritos em dívida ativa com créditos de precatórios.

Já o Estado de Santa Catarina, por meio da Lei 15.300/2010, autoriza a compensação de crédito tributário, inscrito em Dívida Ativa até 31/12/2009, com débito da Fazenda Pública (inclusive de autarquias e fundações) decorrente de precatório judiciário pendente de pagamento.

Cabe ressaltar que a lei catarinense veda a cessão parcial do direito individual sobre precatório. Além disso, de acordo com o previsto no Decreto 3.591/2010, os pedidos de compensação deveriam ser requeridos até 13/12/2010.

Nessa mesma esteira, o Estado de Minas Gerais (Lei 19.407/2010 - Decreto 45.564/2011) instituiu a possibilidade de compensação de precatórios com créditos tributários inscritos até 30/11/2010, tendo como base legal o inciso III, $\S 8^{\circ}$ do artigo 97 do ADCT.

Vale lembrar que tal lei autoriza a realização de acordo direto com detentor de precatórios (original, sucessor ou cessionário) em que será admitida a compensação. Entretanto, destaca-se que não será admitido o acordo sobre parte do valor devido a um mesmo credor em determinado precatório, devendo o ato abranger a totalidade do respectivo crédito.

De outro lado, o Estado de Mato Grosso, conforme dispõe a Lei 8.672/2007 (e alterações até a Lei 9.563/2011), permite a compensação de dívidas relativas a fatos geradores até 31/12/2008. A teor dessa legislação, os débitos poderão ser liquidados à vista, com as reduções dos incisos do art. $8^{\circ}$ da Lei (ex: abatimento de $95 \%$ sobre os juros e multa de mora para dívida tributária; abatimento de $95 \%$ sobre as penalidades decorrentes da inadimplência, quando se tratar de dívida não tributária; abatimento de $80 \%$ sobre 
montante em decorrência de multas infracionais), mediante a compensação com créditos representados por precatórios judiciais.

Ressalte-se que é exigido o prévio recolhimento de honorários e, no caso do ICMS não inscrito, pagamento deverá ser à vista ou parcelado da quota-parte de $25 \%$ dos municípios.

Por fim, o Estado de Pernambuco regula a compensação por meio da Lei complementar 105/2007 e Decreto $\mathrm{n}^{\mathrm{o}}$ 32.549/2008. Inicia-se com análise prévia de requerimento do devedor pela Procuradoria da Fazenda Estadual, que irá observar o interesse público, a conveniência administrativa e a vantagem financeira. Em caso de aprovação, o requerimento será remetido para manifestação dos dirigentes dos órgãos e entidades estaduais interessados. Em caso de aprovação, segue para a manifestação do Conselho de Programação Financeira, sobre a viabilidade orçamentário-financeira da transação. O Conselho aprovando, a transação será assinada pelas partes, seguindo para homologação judicial e devido cumprimento.

Logo, a compensação do artigo $78, \S 2^{\circ}$ do ADCT não dispensa a edição de lei específica, que podem ser encontradas em diversos Estados.

\subsubsection{A compensação após a Emenda Constitucional n ${ }^{62} / 2009$}

Com a promulgação da Emenda Constitucional $n^{\circ}$ 62/2009, duas novas modalidades de compensações foram inseridas na Constituição da República, uma na parte permanente, prevendo a compensação que é realizada no interesse da Fazenda Pública antes da expedição do precatório (artigo 100, $\S \S 9^{\circ}$ e 10 ), e a outra regrada na parte transitória, que se caracteriza como uma espécie de "sanção" que o Presidente do Tribunal poderá aplicar na hipótese de não liberação tempestiva dos recursos relativos aos depósitos mensais para o pagamento de precatórios dos entes federados que estão no regime especial de pagamento (artigo 97, § 10, inciso II do ADCT).

A compensação que é realizada antes da expedição do precatório, prevista no artigo $100, \S 9^{\circ}$ da Constituição Federal, será estudada adiante.

Em relação à compensação "sanção", já mencionada no capítulo anterior, observase que esta modalidade de compensação independe de lei por expressa determinação artigo 
97, § 10, inciso II do ADCT, bastando seja expedida ordem de compensação pelo Presidente do Tribunal. Verifique-se a redação do artigo 97, § 10, inciso II do ADCT:

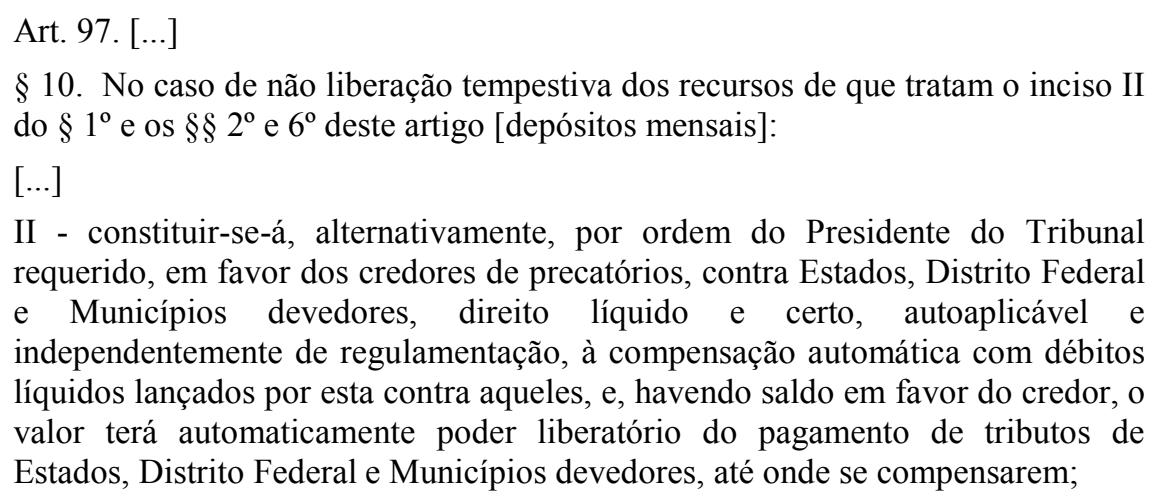
requerido, em favor dos credores de precatórios, contra Estados, Distrito Federal e Municípios devedores, direito líquido e certo, autoaplicável e independentemente de regulamentação, à compensação automática com débitos líquidos lançados por esta contra aqueles, e, havendo saldo em favor do credor, o valor terá automaticamente poder liberatório do pagamento de tributos de Estados, Distrito Federal e Municípios devedores, até onde se compensarem;

Parece evidente que, caso seja expedida ordem reconhecendo o direito à compensação, deverá o Presidente do Tribunal, no mesmo instrumento, prescrever de forma pormenorizada o modo pelo qual tal determinação deverá ser cumprida. Dessa maneira, a ordem judicial fará às vezes da lei exigida para a compensação tributária, em razão de expressa autorização da Constituição da República.

Note-se que enquanto vigente o regime especial instituído pelo artigo 97 do ADCT, não poderá ser aplicado o parcelamento de débitos do artigo 78 do ADCT, do que se infere que a possibilidade de atribuição de poder liberatório para o pagamento de tributos atualmente existente, nos termos da legislação vigente, é apenas a do artigo 97, §10, inciso II do ADCT.

Nesse sentido vem se posicionando o Superior Tribunal de Justiça, estabelecendo que "O poder liberatório do pagamento de tributos, nessa nova disciplina constitucional, não mais decorre da não liquidação das parcelas do precatório vencido, conforme dispunha $\mathrm{o} \S 2^{\circ}$ do art. 78 do ADCT; agora, está restrito à hipótese do inciso II do $\S 10^{\circ}$ do art. 97 do ADCT" 200 .

Ademais, o Superior Tribunal de Justiça vem firmando o entendimento de que as regras do novo regime especial aplicam-se também aos pedidos de compensação formulados anteriormente à edição da Emenda Constitucional n 62/2009, uma vez que "não há direito adquirido a determinado regime jurídico ${ }^{201}$ ".

Além disso, tendo em vista que o regime especial instituído pelo artigo 97 do ADCT abarcou os créditos alimentares, nos termos do artigo 97, $\S 10$, inciso II do ADCT,

\footnotetext{
${ }^{200}$ RMS 31.912/PR, Rel.Ministro Benedito Gonçalves, Primeira Turma, DJe 25/11/2010; No mesmo sentido: RMS 28783/PR, Rel. Ministro Mauro Campbell Marques, Segunda Turma, DJe 18/8/2011.

${ }^{201}$ AgRg no RMS 35.365/PR, Rel. Ministro Castro Meira, Segunda Turma, DJe 10/05/2012.
} 
hoje também é possível, nesta estrita hipótese, a compensação para os créditos dessa natureza.

Contudo, a compensação envolvendo precatórios alimentares ainda é polêmica sob o regime jurídico do artigo 78 do ADCT, como se verifica a seguir.

\subsubsection{A compensação e os precatórios alimentares}

Linhas acima, constatou-se que o artigo $78, \S 2^{\circ}$ do ADCT é norma constitucional de eficácia limitada no que diz respeito à possibilidade de realização de compensações tributárias, na medida em que depende de regulamentação em legislação específica, nos termos do artigo 170 do Código Tributário Nacional para sua efetivação.

O artigo 78 do ADCT suscita, todavia, outra questão de extrema relevância, consistente em se definir se aos precatórios alimentares poderiam ser aplicáveis os efeitos do seu parágrafo segundo. Ou seja, a controvérsia gira em torno da possibilidade de se estender aos precatórios alimentares que não fossem quitados no prazo constitucionalmente previsto os efeitos do artigo 78, 2 do ADCT, especificamente, o efeito liberatório para o pagamento de tributos.

O debate poderia ser evitado pela interpretação literal e isolada do artigo 78 do $\mathrm{ADCT}$, pois este dispositivo constitucional exclui expressamente os créditos alimentares do parcelamento por ele instituído, in verbis:

\footnotetext{
Art. 78. Ressalvados os créditos definidos em lei como de pequeno valor, os de natureza alimentícia, os de que trata o art. 33 deste Ato das Disposições Constitucionais Transitórias e suas complementações e os que já tiverem os seus respectivos recursos liberados ou depositados em juízo, os precatórios pendentes na data de promulgação desta Emenda e os que decorram de ações iniciais ajuizadas até 31 de dezembro de 1999 serão liquidados pelo seu valor real, em moeda corrente, acrescido de juros legais, em prestações anuais, iguais e sucessivas, no prazo máximo de dez anos, permitida a cessão dos créditos.
}

No entanto, outros fatores de inegável relevância fizeram com que a restrição aos créditos alimentares fosse questionada judicialmente, encontrando-se, inclusive, algumas poucas decisões determinando o afastamento da restrição constitucional. Cite-se, como exemplo, a decisão do então Ministro do Supremo Tribunal Federal Eros Grau que, ao se deparar com o tema no controle difuso de constitucionalidade, houve por bem dar provimento ao recurso extraordinário que era objeto de análise, com fundamento no 
disposto no artigo 557, $\S 1^{\circ}$-A, do Código de Processo Civil, reconhecendo a aplicabilidade do poder liberatório para o pagamento de tributos também para os precatórios alimentares (RE no 550.400, DJ de 18/09/2007),

Essa decisão, contudo, foi desafiada por agravo regimental, o qual foi julgado pelo Ministro Luiz Fux, que a tornou sem efeito (RE 550400 AgR, DJe 16/06/2011). No entanto, ainda que sem efeito, a citada decisão serve como demonstrativo da controvérsia provocada pela vedação constitucional acima referida.

O fato é que a matéria ainda não foi decidida de forma definitiva, e os julgamentos dos recursos envolvendo essa discussão estão sendo suspensos no âmbito do Supremo Tribunal Federal, em razão de estar pendente de julgamento do recurso extraordinário $\mathrm{n}^{\circ}$ 566.349 , no qual foi reconhecida a repercussão geral, in verbis:

\footnotetext{
PRECATÓRIO. ART. $78, \quad \S 2^{\circ}, \quad$ DO ATO DAS DISPOSIÇÕES CONSTITUCIONAIS TRANSITÓRIAS. COMPENSAÇÃO DE PRECATÓRIOS COM DÉBITOS TRIBUTÁRIOS. REPERCUSSÃO GERAL RECONHECIDA. Reconhecida a repercussão geral dos temas relativos à aplicabilidade imediata do art. $78, \S 2^{\circ}$, do Ato das Disposições Constitucionais Transitórias - ADCT e à possibilidade de se compensar precatórios de natureza alimentar com débitos tributários.

(RE 566349 RG, Relator(a): Min. CÁRMEN LÚCIA, julgado em 02/10/2008, DJe-206 DIVULG 30-10-2008 PUBLIC 31-10-2008 EMENT VOL-02339-09 PP-01769 )
}

Não obstante isso, centrando-se no mencionados fatores que deram força ao questionamento judicial da exceção constitucionalmente imposta aos precatórios alimentares, observa-se que estes podem ser resumidos em dois, mais relevantes, quais sejam: (i) o volume de precatórios alimentares é muito superior ao de precatórios não alimentares e (ii) o estabelecimento de duas ordens de pagamento de precatórios: alimentares e não alimentares, provocou efeito inverso ao pretendido, pois os precatórios não alimentares foram inseridos no parcelamento decenal, o qual teve foi em grande parte observado pelos entes públicos em mora, ao passo que a ordem cronológica de pagamento dos precatórios alimentares estagnou.

Sobre os precatórios alimentares serem muito mais vultosos que os não alimentares, confira-se o quadro abaixo que demonstra o estoque da dívida de precatórios no Estado de São Paulo em 30/04/2012: 


\begin{tabular}{|l|l|l|}
\hline \multicolumn{3}{|c|}{ Estoque de precatórios do Estado de São Paulo (Referência 30/04/2012) } \\
\hline & Quantidade de Precatórios & Valor (R\$) \\
\hline Administração direta & $8.323($ total a + b) & $16.486 .511 .000,00$ \\
\hline a) Precatórios alimentares & 7.815 & $13.262 .546 .000,00$ \\
\hline b) Precatórios não alimentares & 508 & $3.223 .965 .000,00$ \\
\hline & $2.282($ total c + d) & $2.523 .315 .000,00$ \\
\hline Administração indireta & 2.007 & $1.504 .472 .000,00$ \\
\hline c) Precatórios alimentares & 275 & $1.018 .843 .000,00$ \\
\hline d) Precatórios não alimentares & 275 \\
\hline \multicolumn{2}{|l}{} \\
\hline Valor total do estoque de precatórios (a + b + c + d) & $\mathbf{1 9 . 0 0 9 . 8 2 6 . 0 0 0 , 0 0}$ \\
\hline
\end{tabular}

Da simples leitura do quadro, infere-se, sem sombra de dúvida, que os precatórios alimentares representam a dívida de maior vulto do Estado de São Paulo.

Já em relação à inversão do objetivo constitucional, em virtude da demora no pagamento de precatórios alimentares se comparados ao pagamento dos não alimentares, precisas são as palavras de Fernando Facury Scaff ${ }^{203}$.

\begin{abstract}
O afastamento dos alimentícios se deu em razão do pressuposto de que sempre seriam pagos antes do demais. Ocorre que este pressuposto se revelou falso na prática, uma vez que os atrasos se sucederam e esta classe de precatório permanece no fim da fila de recebimento. É um típico caso em que se evidencia a diferença usualmente exposta pela doutrina norte-americana entre law in books e law in pratice. $\mathrm{O}$ que era para ser um privilégio se revelou um malefício.
\end{abstract}

Ocorre que, não obstante a vedação constitucional tenha gerado flagrante injustiça aos credores originais de precatórios alimentares, que esperam mais pelo pagamento de seus créditos que os credores de precatórios não alimentares, não há como simplesmente se ignorar a vedação constitucional. Se há a restrição, esta deve ser observada.

Nesse sentido é consolidada a jurisprudência no Superior Tribunal de Justiça. Citese a seguinte ementa ${ }^{204}$ :

202 Fonte: Secretaria da Fazenda. Disponível em: <http://www.fazenda.sp.gov.br/contas/precatorios/ precatorios_estoque.pdf $>$. Acesso em 22 nov. 2012.

${ }^{203}$ SCAFF, Fernando Facury. O uso de precatórios para pagamento de tributos após a EC 62. Revista dialética de direito tributário. São Paulo, n. 175, abr. 2010. p. 95-96. 
TRIBUTÁRIO. PROCESSO CIVIL. AGRAVO REGIMENTAL NO AGRAVO DE INSTRUMENTO. COMPENSAÇÃO DE DÉBITO DE ICMS COM CRÉDITOS ALIMENTARES. IMPOSSIBILIDADE. ENTENDIMENTO FIRMADO PELA PRIMEIRA SEÇÃO DO STJ. AGRAVO NÃO PROVIDO.

1. $\mathrm{O}$ art. 78, caput, do ADCT dispõe que os créditos de natureza alimentícia não podem ser objeto de parcelamento e, por consequência, também não podem ser objeto de compensação.

2. A Primeira Seção do Superior Tribunal de Justiça tem entendimento firmado pela impossibilidade de compensação de créditos de natureza alimentar. Precedente.

3. Agravo regimental não provido.

(AgRg no Ag 1256130/PR, Rel. Ministro ARNALDO ESTEVES LIMA, PRIMEIRA TURMA, julgado em 01/12/2011, DJe 12/12/2011)

Ademais, não há argumentos jurídicos que permitam o reconhecimento da inconstitucionalidade da exceção do artigo 78, caput, do ADCT em relação aos precatórios alimentares.

Com efeito, apesar de não haver qualquer restrição ao reconhecimento de inconstitucionalidade de uma emenda constitucional, os argumentos apresentados pelos que defendem a inconstitucionalidade do artigo 78 do ADCT são lastreados em noções muito genéricas, como o espírito de justiça ${ }^{205}$ e igualdade da Constituição da República. Todavia, tais argumentos são amplos demais, e podem abarcar teses defendidas em sentidos absolutamente contrários.

Aventou-se, ainda, a tese de que as sucessivas cessões de precatórios alimentares os desnaturariam, de modo que, para o cessionário, ou para o terceiro que adquirisse o crédito já cedido, este precatório não ostentaria mais a qualidade de alimentar.

Essa tese não parece plausível, uma vez que a cessão de crédito realizada não alterar a natureza alimentar do precatório, havendo apenas a mudança de credor e não da natureza do crédito.

${ }^{204}$ No mesmo sentido: AgRg no RMS 29.544/PR, Primeira Turma, Rel. Min. Benedito Gonçalves, DJe 27/4/10; RMS 34.119/PR, Rel. Ministro Arnaldo Esteves Lima, Primeira Turma, julgado em 13/09/2011, DJe 13/10/2011; RMS 33.409/PR, Rel. Ministro Mauro Campbell Marques, Segunda Turma, julgado em 24/05/2011, DJe 31/05/2011; AgRg no Ag 1326526/SP, Rel. Ministro Humberto Martins, Segunda Turma, julgado em 22/02/2011, DJe 04/03/2011; RMS 31.208/PR, Rel. Min. Castro Meira, Segunda Turma, DJe 23.4.2010; AgRg no RMS 30.340/PR, Rel. Min. Herman Benjamin, Segunda Turma, DJe 30.3.2010; RMS 26.581/PR, Rel. Min. Teori Albino Zavascki, Primeira Turma, DJe 9.6.2008; e RMS 26.908/GO, Rel. Ministra Denise Arruda, Primeira Turma, DJe $1^{\circ} .8 .2008$.

${ }^{205}$ Cf. SCAFF, Fernando Facury. O uso de precatórios para pagamento de tributos após a EC 62. Revista dialética de direito tributário. São Paulo, n. 175, abr. 2010. p.99 
Nesse sentido é a jurisprudência do Superior Tribunal de Justiça, que entende que “A cessão não descaracteriza o caráter alimentar dos precatórios negociados e oferecidos à compensação"206.

Em conclusão, até que o Supremo Tribunal Federal decida a matéria em definitivo, prevalece o entendimento de que se deve observar a exceção imposta aos precatórios alimentares pelo artigo 78 ADCT.

Também nesse sentido já sedimentou a sua jurisprudência o Tribunal de Justiça de São Paulo, conforme se verifica do trecho extraído do acórdão proferido pelo Órgão Especial $^{207}$ : "De fato, na hipótese vertente o crédito da impetrante, obtido na qualidade de cessionária, possui natureza alimentar, característica essa que não se transmuda, e por isso não dispõe do poder liberatório do pagamento de tributos."

Por essas razões, pode-se concluir que o parágrafo $2^{\circ}$ do artigo 78 do ADCT não é aplicável aos precatórios alimentares.

\subsubsection{A compensação entre pessoas jurídicas diferentes}

$\mathrm{O}$ artigo $78, \S 2^{\circ}$, in fine, ao estabelecer hipótese de atribuição de poder liberatório aos precatórios inadimplidos, restringe a sua utilização para o pagamento de tributos da "entidade devedora".

Como não se havia certeza acerca do conceito de entidade devedora, para fins de utilização de precatórios em procedimento de compensação tributária, diversos credores de precatórios pleitearam judicialmente o reconhecimento do direito de utilização de precatórios devidos por autarquias em procedimento de compensação com tributos administrados pelo ente federado ao qual a autarquia estava vinculada.

\footnotetext{
${ }^{206}$ AgRg no RMS 30.340/PR, Rel. Min. Herman Benjamin, DJe 30/3/2010. Nessa linha: REsp 28.811/PR, Rel. Min. Denise Arruda, DJe 18/06/2009 e RMS 35.372/PR, Rel. Min. Benedito Gonçalves, DJe 25.10.2011. AgRg no RMS 28.547/PR, Rel. Ministro Napoleão Nunes Maia Filho, Primeira Turma, julgado em 16/02/2012, DJe 08/03/2012.

207 Apelação Cível n 0064705-27.2011.8.26.0000, Rel. Des. Mário Devienne Ferraz, julgamento realizado em 16/11/2011.
} 
Essa tese estava fundamentada, como aponta Fernando Facury Scaff ${ }^{208}$, na ideia de que "Existem vários órgãos ordenadores de despesas- mas só existe um arrecadador em um ente federado".

Essa tese, no entanto, não encontrou respaldo no Poder Judiciário, sendo rechaçada pelo Superior Tribunal de Justiça. Confiram-se os excertos extraídos de acórdãos proferidos pela Corte Superior:

Não há falar em correspondência entre credor e devedor uma vez que os titulares dos créditos em análise são pessoas jurídicas distintas. A titularidade dos créditos tributários de ICMS é do Estado do Rio Grande do Sul, e os créditos oriundos de precatório, de titularidade do IPERGS, autarquia previdenciária, pessoa jurídica distinta com autonomia administrativa e financeira.

(AgRg no REsp 1238247/RS, Rel. Ministro ARNALDO ESTEVES LIMA, PRIMEIRA TURMA, julgado em 05/06/2012, DJe 13/06/2012)

Na falta de previsão expressa, é inviável extinguir crédito de IPVA por meio de compensação com precatório devido por pessoa jurídica distinta (autarquia estadual - Ipergs). Precedentes do STJ.

[...] A inexistência de identidade entre o devedor do precatório (Ipergs) e o credor do tributo (Estado) afasta a incidência do dispositivo constitucional.

(AgRg no AREsp 57.701/RS, Rel. Ministro HERMAN BENJAMIN, SEGUNDA TURMA, julgado em 29/05/2012, DJe 26/06/2012)

A jurisprudência do Superior Tribunal de Justiça é pacífica no sentido de considerar impossibilitada a compensação de créditos tributários de ICMS com precatórios devidos por pessoa jurídica de direito público de natureza distinta, a exemplo do IPERGS, autarquia que é dotada de autonomia administrativa e financeira à parte.

(AgRg no AREsp 115.109/RS, Rel. Ministro HUMBERTO MARTINS, SEGUNDA TURMA, julgado em 17/05/2012, DJe 25/05/2012)

O entendimento do Superior Tribunal de Justiça mostra-se acertado, pois as entidades da administração pública indireta são instituídas a partir da criação de pessoas jurídicas próprias, distintas da administração direta.

E justamente por serem as entidades da administração indireta dotadas de personalidade jurídica própria, contando ainda com autonomia administrativa, operacional e financeira, a responsabilidade destas não se confunde, para fins de compensação, com a responsabilidade da administração direta a que ela se vincula.

${ }^{208}$ SCAFF, Fernando Facury. O uso de precatórios para pagamento de tributos. In: ROCHA, Valdir de Oliveira (coord.). Grandes questões atuais de direito tributário. v. 13. São Paulo: Dialética, 2009. p.112. 
Desse modo, uma dívida de uma entidade da administração indireta, representada por um precatório judicial, não é compensável com um crédito tributário da administração direta. O patrimônio de uma pessoa jurídica não responde pelas dívidas da outra.

Especificamente no que tange à autarquia, que representa grande parte dos julgados do Superior Tribunal de Justiça, destaca-se a doutrina de Celso Antônio Bandeira de Mello, que a define como sendo uma pessoa jurídica de direito público de capacidade exclusivamente administrativa ${ }^{209}$ e que, sob essa perspectiva, teria na outorga de patrimônio público um acessório necessário, sem o qual a capacidade de autoadministração não existiria.

Quer isso dizer, portanto, que a autarquia, uma pessoa jurídica de direito público, deverá ser dotada de patrimônio próprio para não sofrer ingerência da administração direta a que está vinculada (autoadministração). De outro lado, desse patrimônio próprio decorrerá a sua responsabilidade pelas dívidas oriundas de decisões judiciais transitadas em julgado.

Paulo Roberto Lyrio Pimenta ${ }^{210}$ aponta que uma solução para o problema estaria na diferenciação de tipos de orçamentos, prevista no artigo 165 , parágrafo $5^{\circ}$ da Constituição da República, sendo eles: orçamento fiscal, orçamento de investimento e orçamento da seguridade social, de modo que poderiam ser considerados como mesma entidade devedora os entes federados que fossem detentores da competência para a instituição do tributo que estivesse previsto como fonte de receita para o orçamento em que inserido o precatório.

Assim leciona o citado professor:

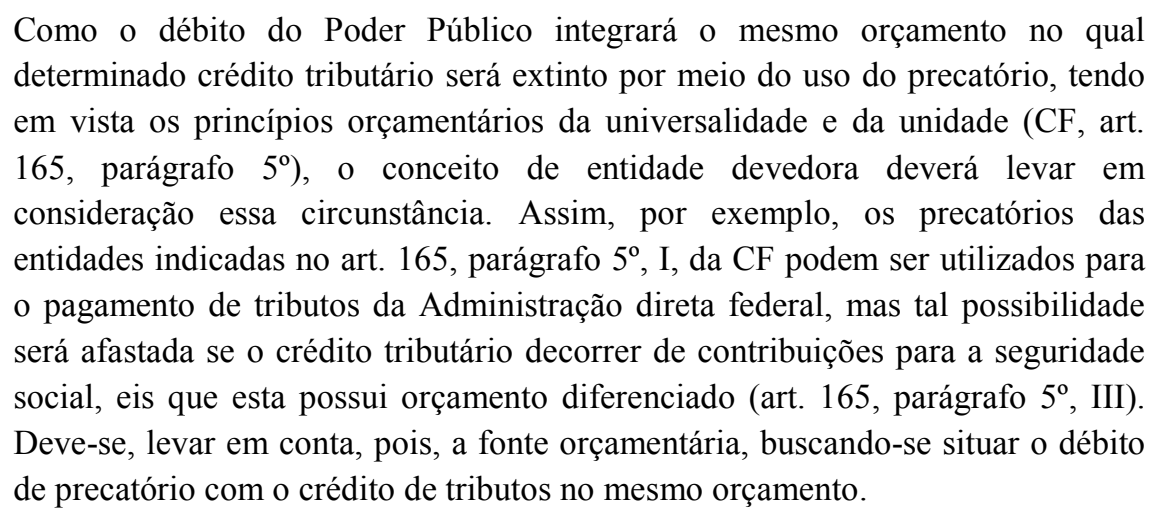

\footnotetext{
${ }^{209}$ MELLO, Celso Antonio Bandeira de. Natureza e regime jurídico das autarquias. São Paulo: Revista dos Tribunais. 1968. passim.

${ }^{210}$ PIMENTA, Paulo Roberto Lyrio. Sumula vinculante e repercussão geral em matéria tributária: cabimento e problemática. In: ROCHA, Valdir de Oliveira (coord.). Grandes questões atuais de direito tributário. v. 13. São Paulo: Dialética, 2009. p. 127.
} 
A opção é interessante, mas não serviria para a questão ora aventada, pois, como exposto, não se permite confundir as distintas personalidades jurídicas do ente federado e de uma autarquia, especificamente no que tange à autonomia administrativa.

Diante disso, depreende-se que a compensação entre precatórios e créditos tributários deve estar limitada às hipóteses em que a pessoa jurídica credora do tributo seja a mesma devedora do precatório.

\subsubsection{A compensação do artigo 100, $\S 9^{\circ}$ da Constituição Federal}

A Emenda Constitucional n ${ }^{\circ} 62$ de dezembro de 2009, ao inserir os parágrafos $9^{\circ} \mathrm{e}$ $10^{\circ}$ no artigo 100 da Constituição da República, inovou o ordenamento jurídico no que tange ao pagamento das dívidas públicas decorrentes de decisões judiciais, permitindo às Fazendas Públicas, antes da expedição do precatório, informarem a existência de débitos do credor original do precatório a ser expedido, para que tais valores sejam compensados pelos valores reconhecidos como devidos pela decisão judicial.

Não se trata propriamente, pois, de compensação entre precatórios e créditos tributários, haja vista que nesta modalidade de compensação o precatório sequer foi expedido.

Os parágrafos $9^{\circ}$ e 10 do artigo 100 da Constituição da República estão assim redigidos:

\footnotetext{
Art. $100[\ldots]$

$\S 9^{\circ}$ No momento da expedição dos precatórios, independentemente de regulamentação, deles deverá ser abatido, a título de compensação, valor correspondente aos débitos líquidos e certos, inscritos ou não em dívida ativa e constituídos contra o credor original pela Fazenda Pública devedora, incluídas parcelas vincendas de parcelamentos, ressalvados aqueles cuja execução esteja suspensa em virtude de contestação administrativa ou judicial.

$\S 10$. Antes da expedição dos precatórios, o Tribunal solicitará à Fazenda Pública devedora, para resposta em até 30 (trinta) dias, sob pena de perda do direito de abatimento, informação sobre os débitos que preencham as condições estabelecidas no $\S 9^{\circ}$, para os fins nele previstos.
} 
Da leitura do citado dispositivo constitucional, infere-se que é facultado ${ }^{211}$ à Fazenda Pública, antes da expedição do precatório, e sempre no seu interesse, "abater" da condenação que lhe foi imposta os débitos tributários devidos pelo credor original do precatório a ser expedido (aquele que será o titular do valor requisitado).

Assim, após devidamente comunicada, a Fazenda Pública que sofreu a condenação judicial poderá informar ao juízo da execução, no prazo de trinta dias contados do recebimento da solicitação, a existência de débitos tributários devidos pelo credor originário que são passíveis de compensação sob pena de perder o direito ao "abatimento" de tais valores quando da expedição do precatório.

Poderão ser compensados, nesta sistemática, todos os débitos tributários do credor original que não estejam com a sua exigibilidade suspensa nos termos do artigo 151 do Código Tributário Nacional, com exceção dos parcelamentos ordinários, conforme adiante se explicará.

A compensação prevista nos parágrafos $9^{\circ}$ e 10 do artigo 100 da Constituição Federal ensejou diversas polêmicas na doutrina, bem como aguçou a inventividade daqueles que se dedicam ao chamado "mercado de precatórios" 212 , com toda a sorte de teses envolvendo a matéria.

Como exemplo dessa criatividade, pode-se citar a tese que defende que o novel regramento constitucional permitiria a compensação de débitos tributários de terceiros com os valores reconhecidos na decisão judicial, pelo fato de que essa compensação deveria ser realizada antes da expedição do precatório.

Ora, não se mostra plausível admitir a compensação dos valores reconhecidos na decisão judicial transitada em julgado com créditos de terceiros, ainda que antes da expedição do precatório, pois tal interpretação iria de encontro à expressa previsão constitucional de que esta compensação é restrita aos "débitos líquidos e certos, inscritos ou não em dívida ativa e constituídos contra o credor original pela Fazenda Pública devedora" (artigo 100, § $9^{\circ}$ da Constituição da República).

\footnotetext{
${ }^{211}$ Nesse sentido leciona Fernando Facury Scaff: Observe-se que não se trata de uma causa extintiva do direito de a Fazenda Pública cobrar seus crédito; pela dicção constitucional ela apenas perderá o direito de compensar caso não informe ao Tribunal, antes da expedição do precatório, o montante a que se acha credora. A cobrança, pelos demais meios jurídicos, poderá ser efetuada. (SCAFF, Fernando Facury. Uso de precatórios para pagamento de tributos após a EC 62. Revista dialética de direito tributário, São Paulo, n. 175, abr. 2010. p. 92).

${ }^{212}$ Scaff aponta que a finalidade desse dispositivo constitucional seria o de facilitar o mercado de precatórios, apontando que : "O escopo é que o valor dos precatórios corresponda ao montante líquido de dívidas para com o devedor, facilitando sua comercialização para com terceiros"(Ibidem. loc. cit.).
} 
Nessa linha se posiciona Araken de Assis ${ }^{213}$, que classifica essa modalidade de compensação como sendo uma espécie de “exceção de compensação ${ }^{214 "}$ oponível pela Fazenda Pública ao credor original. Assim leciona o citado autor:

Por outro lado, o art. 100, § 9, na redação da EC 62/2009, contemplou a possibilidade de a Fazenda Pública devedora compensar seus créditos, correspondentes aos "débitos líquidos e certos, inscritos ou não em dívida ativa e constituídos contra o credor original", incluindo as parcelas vincendas dos parcelamentos.

$[\ldots]$

A compensação realizar-se-á, na hipótese de cessão, perante o credor original, que é cedente. Nada diz quanto ao eventual compensação perante o cessionário. Em princípio, impõe-se a resposta positiva, estimando-se que o art. 100, $\S 9^{\circ}$, visou tão só a reforçar a possibilidade de o cedido (Fazenda Pública) excepcionar a compensação perante o cedente, a despeito da cessão. Mas a redação desse dispositivo ensejará controvérsias, porque o cessionário rejeitará a compensação.

Deve-se notar também que as "parcelas vincendas de parcelamentos" mencionadas no artigo 100, $\S 9^{\circ}$ da Constituição Federal também se referem exclusivamente aos débitos tributários do credor originário (vencedor da ação judicial).

No que diz respeito aos pontos polêmicos dessa modalidade de compensação, inicia-se pela tese que defende a impossibilidade de serem levados à compensação débitos tributários que ainda não tenham sido inscritos em dívida ativa, ao entendimento de que tais créditos não gozariam de certeza e liquidez exigidas para a compensação, não obstante tal permissão estar expressamente prevista no artigo $100, \S 9^{\circ}$ da Constituição da República.

Compartilha desse entendimento Marcus $\mathrm{Abraham}^{215}$, que assim pondera:

De fato, o crédito já existe antes mesmo da inscrição em dívida ativa, porém, ainda não era dotado de liquidez e certeza. Portanto, a ausência de inscrição em dívida ativa retira a certeza e liquidez da dívida e inviabiliza a sua cobrança pela Fazenda Pública, impossibilitando, assim, de se realizar qualquer compensação, inclusive a compensação com precatórios ora analisada.

${ }^{213}$ Cf. ASSIS, Araken. Manual da Execução. 14. ed. rev. atual. ampl. São Paulo: RT, 2012. p.1109.

${ }^{214}$ Considerada como uma espécie de exceção, essa modalidade de compensação se assemelharia a uma condição para o recebimento de precatório, como a que foi instituída em 21 de dezembro de 2004 pela Lei $\mathrm{n}^{\circ} 11.033 / 04$, que em seu artigo 19, estabelecia que, excetuados os créditos alimentares e os de pequeno valor, "O levantamento ou a autorização para depósito em conta bancária de valores decorrentes de precatório judicial somente poderá ocorrer mediante a apresentação ao juízo de certidão negativa de tributos federais, estaduais, municipais, bem como certidão de regularidade para com a Seguridade Social, o Fundo de Garantia do Tempo de Serviço - FGTS e a Dívida Ativa da União, depois de ouvida a Fazenda Pública". Essa exigência foi julgada inconstitucional pelo Supremo Tribunal Federal, ao entendimento de que a matéria não poderia ser tratada no plano infraconstitucional (ADI n³453).

215 ABRAHAM, Marcus. Reflexões sobre a EC 62/2009: a compensação de precatórios com créditos da fazenda pública. Revista tributária e de finanças públicas. São Paulo: Revista dos Tribunais, a. 18, n. 94, set.-out. 2010. p. 248. 
Há coerência nessa argumentação, contudo, não se vislumbra qualquer impedimento para que sejam compensados débitos não inscritos em dívida ativa, basta se considerar a situação em que a discussão administrativa tenha se encerrado sem que tenha havido tempo hábil para a inscrição do débito em dívida ativa ou, ainda, nas hipóteses em que o crédito levado à compensação esteja sujeito ao lançamento por homologação, caracterizando aquilo que a jurisprudência consolidou como débito tributário declarado e não pago $^{216}$.

Note-se que, especificamente em relação ao débito tributário declarado e não pago, o próprio Marcus Abraham ${ }^{217}$ concorda com a viabilidade da compensação envolvendo débitos tributários não inscritos em dívida ativa, in verbis:

Talvez a única ressalva que se possa tecer a respeito destes créditos que ainda
não foram objeto de inscrição é a relativa aos que se originaram do
autolançamento realizado pelo próprio contribuinte. Isso porque os tributos
declarados e não pagos no seu vencimento foram constituídos pelo próprio
contribuinte, a partir da sua "confissão" em declaração dirigida à Fazenda
Pública, o que nos levaria a conclusão da desnecessidade do procedimento de
controle da legalidade, decorrente da inscrição como mecanismo de legitimação
e validação do crédito público.

Sobre a compensação do artigo 100, $\S 9^{\circ}$ da Constituição Federal, questiona-se também a inexistência de previsão em sede constitucional que assegure ao credor originário (autor da ação judicial) oportunidade de provar que eventuais créditos tributários apontados pela Fazenda Pública não são devidos ou que estão com a sua exigibilidade suspensa, o que impediria, fossem eles compensados.

Nessa senda é a advertência de $\mathrm{Scaff}^{218}$, apontando que "Se não for instaurada uma espécie de contraditório nesta fase, os problemas se multiplicarão, atrasando ainda mais a determinação do valor de cada precatório".

O problema da ausência de norma constitucional permitindo ao vencedor da ação judicial demonstrar que os créditos tributários informados pela Fazenda Pública não são devidos, ou que estão com a sua exigibilidade suspensa, foi satisfatoriamente suprida pelos artigos $6^{\circ}$, da Resolução $n^{\circ} 115$ de 2010 do Conselho Nacional de Justiça ${ }^{219}$ e, em âmbito

\footnotetext{
${ }^{216}$ Súmula 446 do Superior Tribunal de Justiça: "Declarado e não pago o débito tributário pelo contribuinte, é legítima a recusa de expedição de certidão negativa ou positiva com efeito de negativa".

${ }^{217}$ ABRAHAM, Marcus. Reflexões sobre a EC 62/2009: a compensação de precatórios com créditos da fazenda pública. Revista tributária e de finanças públicas. São Paulo: Revista dos Tribunais, a. 18, n. 94, set.-out. 2010. p.248.

${ }^{218} \mathrm{O}$ uso de precatórios para pagamento de tributos após a EC 62. Revista dialética de direito tributário. São Paulo, n. 175, abr. 2010. p. 92.

${ }^{219}$ Com as alterações promovidas pelas Resoluções CNJ 123/2010 e 145/2011.
} 
federal, pelos artigos 30 e seguintes da Lei $\mathrm{n}^{\circ} 12.431 / 2011$, os quais serão a seguir analisados.

Mais tormentosa, contudo, é a exceção contida no artigo $100, \S 9^{\circ}$, in fine, a qual autoriza a compensação dos valores devidos na ação judicial com créditos tributários parcelados, os quais também estariam com a sua exigibilidade suspensa, por força do artigo 151, inciso XI do Código Tributário Nacional.

Ao nosso sentir, a solução desse problema se dá pela interpretação de que seriam compensáveis, nos termos do artigo $100, \S 9^{\circ}$, da Constituição Federal, apenas os créditos tributários que tenham sido objeto de parcelamentos ordinários, hipóteses em que não há qualquer benesse ao contribuinte.

Desse modo, a compensação não poderia atingir os parcelamentos excepcionais, pois, ao mesmo tempo em que estes parcelamentos impõem condições aos contribuintes que desejam a ele aderir, oferecem-lhes vantagens muito atraentes, como a redução de multa e juros. Assim, não seria razoável a Fazenda Pública incentivar o contribuinte a regularizar a sua situação fiscal para no momento seguinte cobrar-lhe de uma só vez a sua dívida.

Nesse sentido se manifesta Abraham ${ }^{220}$ :

Devemos lembrar, também, que é muito comum nos programas de parcelamento recentemente criados pelo Estado brasileiro a fixação de condições para a sua adesão pelo devedor. Dentre estas condições, temos a desistência dos questionamentos administrativos ou judiciais a respeito da dívida como uma regra comum.

Ora impor ao cidadão a desistência da discussão do seu direito para ingressar no programa de parcelamento - que é proposto pelo próprio Estado como um favor legal - e logo depois, desfazer aquele ato jurídico perfeito e acabado, para quitar a obrigação de uma só vez através da compensação pode, de alguma maneira, resvalar no valor da segurança jurídica, necessário para garantir a estabilidade das relações sociais.

$[\ldots]$

Portanto, não nos parece razoável que, em um Estado Democrático de Direito, a desconstituição de um parcelamento concedido ao cidadão para se efetivar a compensação das parcelas vincendas com os precatórios possa ser feita de plano, sem, de alguma maneira, se atingir o direito adquirido e a segurança jurídica.

É bem verdade, de outro lado, que, por apresentarem condições especiais, tais parcelamentos excepcionais assumem natureza jurídica de transação, conforme

${ }^{220}$ ABRAHAM, Marcus. Reflexões sobre a EC 62/2009: a compensação de precatórios com créditos da fazenda pública. Revista tributária e de finanças públicas. São Paulo: Revista dos Tribunais, a. 18, n. 94, set.-out. 2010. p. 250-251. 
jurisprudência do Superior Tribunal de Justiça ${ }^{221}$, de modo que, também por esse motivo, não incidiria nos parcelamentos especiais a previsão do artigo $100, \S 9^{\circ}$ da Constituição Federal.

Nessa linha de raciocínio, seria viável a compensação do artigo $100, \S 9^{\circ}$ da Constituição Federal para os débitos objeto de parcelamentos especiais, se expressamente com ela concordasse o contribuinte, consentindo, também, com os abatimentos das parcelas remanescentes, desde que, por óbvio, fossem mantidas as vantagens para o cálculo dos valores devidos, em observância ao princípio da segurança jurídica e respeito ao ato jurídico perfeito e ao direito adquirido, todos constitucionalmente assegurados.

Por fim, questiona-se a possibilidade de serem compensados tributos com créditos de natureza alimentar.

Ora, se a compensação disciplinada pelo artigo 100 , $\S 9^{\circ}$, é realizada antes da expedição do precatório, a ela não se aplicam as restrições incidentes sobre os precatórios alimentares, não sendo, neste caso, a natureza da dívida em si um óbice à compensação.

Nesse sentido são precisas as palavras de Abraham $^{222}$ :

\begin{abstract}
A metodologia instituída pelo $\S 9^{\circ}$ do art. 100, ao estabelecer a compensação entre os créditos da Fazenda Pública e os precatórios, não fixou qualquer distinção em face da sua natureza ou espécie. Assim, como existem os precatórios comuns e os precatórios alimentares, ambos, a princípio, poderiam ser objetos da referida compensação. Afinal, se a Carta quisesse estabelecer qualquer limitação ou restrição à compensação ela teria expressamente previsto.
\end{abstract}

Outras questões envolvendo sobre a matéria decorrem da sua regulamentação pelas normas infraconstitucionais.

Com efeito, apesar de expressamente autoaplicável, por força da previsão parágrafo

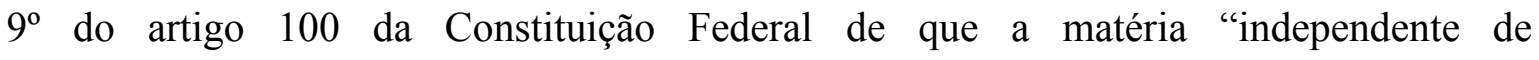
regulamentação", esta modalidade de compensação foi regulamentada pelo Conselho Nacional de Justiça - CNJ, por meio da Resolução n 115 de 2010, e na esfera federal pela Lei ${ }^{\circ} 12.431 / 2011$.

${ }^{221}$ Confira-se: "O parcelamento do débito tributário envolve transação do contribuinte com o fisco e licitamente impede a discussão judicial acerca do fato gerador ou do montante da dívida originária". (REsp no 1.065.940 - SP, Relator Ministro Francisco Falcão, Primeira Turma, Acórdão disponibilizado no DJE em 03/10/2008) e "O REFIS, espécie de transação, só autoriza a suspensão da execução quando homologado" (REsp n 427358/RS, Segunda Turma, Relatora Ministra Eliana Calmon, DJ de 16/09/02).

${ }^{222}$ ABRAHAM, Marcus. Reflexões sobre a EC 62/2009: a compensação de precatórios com créditos da fazenda pública. Revista tributária e de finanças públicas. São Paulo: Revista dos Tribunais, a. 18, n. 94, set.-out. 2010. p. 244. 
A Resolução $n^{\circ}$ 115/2010 do Conselho Nacional de Justiça trata da compensação prevista no artigo $100, \S 9^{\circ}$ da Constituição da República no seu artigo $6^{\circ}$, que possui a seguinte redação:

Art. $6^{\circ}$. O juízo da execução, antes do encaminhamento do precatório ao Tribunal, para os efeitos da compensação prevista nos $\S \S 9^{\circ}$ e 10 do art. 100 da Constituição Federal, intimará o órgão de representação judicial da entidade executada para que informe, em 30 dias, a existência de débitos que preencham as condições estabelecidas no $\S 9^{\circ}$, sob pena de perda do direito de abatimento dos valores informados.

$\S 1^{\circ}$ Havendo resposta de pretensão de compensação pela entidade devedora, o juiz da execução decidirá o incidente nos próprios autos da execução, após ouvir a parte contrária que deverá se manifestar em 10 (dez) dias, valendo-se, se necessário, do exame pela contadoria judicial.

$\S 2^{\circ}$ Quando a intimação for realizada no âmbito do Tribunal, havendo pretensão de compensação pela entidade devedora, o Presidente determinará a autuação de processo administrativo e ouvirá a parte contrária, que deverá se manifestar em 10 (dez) dias, decidindo em seguida, valendo-se, se necessário, do exame pela contadoria do Tribunal e cabendo recurso na forma prevista no seu regimento interno.

$\S 3^{\circ}$ Tornando-se definitiva a decisão que determina a compensação dos valores a serem pagos mediante precatório, deverá a Vara ou o Tribunal, conforme o órgão que decidiu sobre a compensação, emitir certificado de compensação para fins de controle orçamentário e financeiro, juntando-os ao processo administrativo de expedição do precatório.

$\S 4^{\circ}$ A compensação se operará no momento da efetiva expedição do certificado de compensação, quando cessará a incidência de correção monetária e juros moratórios sobre os débitos compensados.

$\S 5^{\circ} \mathrm{O}$ procedimento de compensação, quando realizado no âmbito do Tribunal, não impedirá a inscrição do precatório apresentado até $1^{\circ}$ de julho de um ano no orçamento do ano seguinte da entidade devedora, deduzindo-se o valor compensado, caso reconhecida posteriormente a compensação.

Do artigo $6^{\circ}$ da Resolução acima transcrita, destacam-se as previsões dos parágrafos $1^{\circ}, 4^{\circ}$ e $5^{\circ}$. No parágrafo primeiro está disciplinado que a parte contrária será ouvida no prazo de dez dias sobre os débitos tributários apresentados pela Fazenda Pública, o que afasta a tese de ausência de previsão de contraditório neste procedimento de compensação.

Já os parágrafos $4^{\circ}$ e $5^{\circ}$, determina que o procedimento de compensação não altera o procedimento do artigo 100 da Constituição da República, bem como que a compensação será efetivada apenas no momento do regular pagamento do precatório, impedindo, assim, questionamentos sobre a quebra da ordem cronológica de pagamento dos precatórios.

A Lei $n^{\circ} 12.431 / 2011$, que disciplinou a compensação em comento para os débitos administrados pela Fazenda Pública Federal, estabeleceu detalhadamente o modo pelo qual a referida compensação deverá ser operacionalizada. 
Assim, de acordo com o artigo 30, $\S 3^{\circ}$ da citada lei, a Fazenda Pública Federal, antes da requisição do precatório ao Tribunal, deverá ser intimada, no prazo de trinta dias para se manifestar sobre a existência de débitos do autor da ação, cujos valores poderão ser abatidos a título de compensação.

Ressalva o parágrafo $6^{\circ}$ do mesmo artigo, que somente poderão ser objeto da compensação de que trata o artigo 100, $\S 9^{\circ}$ da Constituição Federal, os créditos e os débitos oriundos da mesma pessoa jurídica que será a devedora do precatório.

Nota-se, portanto, que em âmbito federal é legal a vedação de compensação entre pessoas jurídicas distintas.

$\mathrm{O}$ artigo 31 da Lei $\mathrm{n}^{\circ}$ 12.431/2011 disciplina as hipóteses em que se permite a apresentação de impugnação pelo beneficiário do precatório, no prazo de 15 dias. Assim, poderá versar a impugnação sobre:

I. erro aritmético do valor do débito a ser compensado;

II. Suspensão da exigibilidade do débito, ressalvado o parcelamento;

III. suspensão da execução, em virtude do recebimento de embargos do devedor com efeito suspensivo ou em virtude de outra espécie de contestação judicial que confira efeito suspensivo à execução; ou

IV. extinção do débito.

No parágrafo $2^{\circ}$ do citado artigo, há a ressalva de que "outras exceções somente poderão ser arguidas pelo beneficiário em ação autônoma".

Apresentada a impugnação, o representante judicial da pessoa jurídica devedora do precatório na ação de execução será intimado pessoalmente para se manifestar no prazo de 30 dias (artigo 32).

Findo esse prazo, o juiz proferirá decisão em dez dias, "restringindo-se a identificar eventuais débitos que não poderão ser compensados, o montante que deverá ser submetido ao abatimento e o valor líquido do precatório" (artigo 33).

Contra essa decisão caberá agravo de instrumento, o qual será recebido com efeito suspensivo, impedindo a requisição do precatório ao Tribunal até o seu trânsito em julgado (artigo 34), admitindo-se, entretanto, a requisição ao Tribunal de precatório relativo à parte incontroversa da compensação (artigo 35). 
Para Marcus Abraham, em estudo elaborado antes da edição da Lei ${ }^{\circ}$ 12.431/2011, essa decisão deveria ser objeto de mandado de segurança, em razão da natureza não jurisdicional da atividade desenvolvida pelo juízo da execução. Assim leciona o aludido autor $^{223}$ :

\begin{abstract}
Ora se o credor do precatório, devedor da Fazenda pública, entender inexigível o crédito apresentado para a compensação, por qualquer razão de fato ou de direito, deveria possuir - previamente estabelecido em lei - todos os mecanismos válidos e eficazes para apresentar sua oposição.

Considerando que a compensação dos valores a serem pagos por precatórios com os créditos da Fazenda Pública em nome do devedor é feita em momento processual cuja fase jurisdicional propriamente dita já estaria encerrada, poderse-ia até mesmo entender que a decisão a respeito do incidente sobre a compensação teria natureza administrativa, atacável por via de Mandado de Segurança, e não como decisão interlocutória, recorrível pelo Agravo de Instrumento.
\end{abstract}

Ainda em relação à citada lei federal, determina o artigo 36 que a compensação será considerada realizada na data da decisão judicial que a determinou transitar em julgado, ficando sob condição resolutória de ulterior disponibilização financeira do precatório.

Para os débitos parcelados, em caso de compensação parcial, haverá a quitação das parcelas na seguinte ordem:

I - crescente da data de vencimento das prestações vencidas; e

II - decrescente da data de vencimento das prestações vincendas.

Transitada em julgado a decisão que determinou a compensação, os atos de cobrança dos débitos ficam suspensos até que haja disponibilização financeira do precatório, sendo cabível a expedição de certidão positiva com efeitos de negativa, entendendo-se por disponibilização financeira do precatório o ingresso de recursos nos cofres da União.

Ainda de acordo com a lei federal em comento, os efeitos financeiros da compensação, para fins de repasses e transferências constitucionais, somente ocorrerão no momento da disponibilização financeira do precatório.

Em caso de cancelamento do precatório, será intimada a Fazenda Pública Federal para dar prosseguimento aos atos de cobrança (artigo 41).

${ }^{223}$ ABRAHAM, Marcus. Reflexões sobre a EC 62/2009: a compensação de precatórios com créditos da fazenda pública. Revista tributária e de finanças públicas. São Paulo: Revista dos Tribunais, a. 18, n. 94, set.-out. 2010. p. 238-239. 
Por fim, o artigo 44 da lei em análise exclui desse procedimento a obrigação originada em sentença judicial transitada em julgado cuja prestação seja definida em lei como de pequeno valor para a Fazenda Pública Federal.

Essa previsão decorre do fato de que as obrigações de pequeno valor, como visto alhures, são constitucionalmente excluídas da sistemática dos precatórios (artigo 100, $\S 3^{\circ}$ da Constituição da República).

Desse modo, parece equivocado o entendimento de Artur Ricardo Ract, para quem $^{224}$ :

Acreditamos que mesmo com a disposição legal desfavorável à compensação de RPV com tributos existiria tal possibilidade se aplicássemos uma interpretação sistemática do ordenamento jurídico, em especial, a celeridade processual, que permitiria o encontro de contas entre o ente federativo e o credor de RPV de imediato, sem maiores complicações burocráticas, uma vez que, em muitas das vezes o credor de pequenos valores demora mais de um ano para receber a mencionada quantia.

Não obstante isso, como bem alerta Marcus Abraham ${ }^{225}$ :

Todavia, na prática forense, temos visto que a grande maioria dos magistrados vem demandando às Fazendas Públicas informações dos seus créditos antes de expedir as requisições de pequeno valor (RPV), sendo que as orientações a respeito do procedimento de compensação, expedidas pelos Tribunais, não vêm tratando especificamente da matéria.

Percebe-se que a regulamentação infraconstitucional da matéria é de extrema valia, pois além de resolver os diversos problemas aventados acima, pertinentes à compensação tributária com precatórios já expedidos, dirime as dúvidas próprias dessa modalidade de compensação.

De outro lado, antevê-se a nítida dificuldade que os Estados-Membros, o Distrito Federal e os Municípios enfrentarão para disciplinar essa modalidade de compensação, caso assim o desejarem, uma vez que, por disposição expressa, a Lei n ${ }^{\circ} 12.431 / 11$ é inaplicável aos créditos tributários da Fazenda Pública Estadual Municipal e Distrital.

Com efeito, questões como a previsão do recurso cabível, matéria de Direito Processual, são de competência exclusiva da União, artigo 22, inciso I da Constituição Federal, e não poderão ser disciplinadas pela legislação local.

${ }^{224}$ RACT, Artur Ricardo. Precatórios: a compensação de tributos com o advento da Lei 12.431/2011. Revista tributária e de finanças públicas, São Paulo: RT, a. 19, v. 100, set-out. 2011. p.197.

225 ABRAHAM, Marcus. Reflexões sobre a EC 62/2009: a compensação de precatórios com créditos da fazenda pública. Revista tributária e de finanças públicas. São Paulo: Revista dos Tribunais, a. 18, n. 94, set.-out. 2010. p. 241. 
De todo modo, na ausência de legislação específica estadual, distrital ou municipal, a matéria será regida pela Resolução no 115/2010 do Conselho Nacional de Justiça, acima analisada.

\subsection{O precatório como garantia da execução fiscal}

Conforme visto acima, discute-se a possibilidade de utilização de precatórios como forma de extinção de créditos tributários em duas situações, quais sejam, o pagamento e a compensação.

Outro modo de manejo de precatórios para fins tributários, que é reiteradamente observado, consiste em apresentá-los como garantia de uma execução fiscal.

Todavia, também nessa hipótese de uso de precatórios para fins tributários a discussão, apesar de se iniciar por uma premissa diferente, caminhará para as duas modalidades de extinção do crédito tributário já estudadas, a saber: o pagamento e a compensação, sobretudo nessa última.

Desse modo, todas as considerações já expendidas sobre a compensação e o pagamento refletirão no tópico que ora se inicia, pois a satisfação do crédito tributário perseguido em uma execução fiscal, caso o precatório seja aceito como garantia, ocorrerá inevitavelmente por meio de uma compensação ${ }^{226}$. É o que se passa a expor.

\subsubsection{O regramento da garantia à execução fiscal}

A execução judicial para cobrança da "dívida ativa"227 da União, dos Estados, do Distrito Federal, dos Municípios e respectivas autarquias é regida pela Lei $n^{\circ} 6.830$ de 22

\footnotetext{
${ }^{226}$ A utilização de precatório como garantia de execução fiscal foi objeto de estudo no nosso "O precatório como garantia da execução fiscal à luz da atual jurisprudência do Superior Tribunal de Justiça" (Revista Dialética de Direito Tributário, São Paulo, n. 203, 2012, p. 54 a 64), do qual extraímos grande parte deste capítulo.

${ }^{227}$ Sobre a locução "Dívida Ativa da Fazenda Pública": "Considero uma expressão hermafrodita. Toda a dívida há de estar no passivo, e não no ativo. O Fisco, entretanto, potencializou a dívida do contribuinte para poder, então, prestigiar seu crédito, e aí resultou a expressão 'dívida ativa'. A expressão, no entanto, fora criada pela Lei $\mathrm{n}^{\circ} 4.320$, de março de 1964, que disse o que não deveria ter dito: Dívida ativa, tributária e não tributária, é crédito da Fazenda Pública.Ora se é o crédito da Fazenda Pública, por que
} 
de setembro de 1980, e, subsidiariamente, pelo Código de Processo Civil (artigo $1^{\circ}$ da Lei $\left.\mathrm{n}^{\circ} 6.830 / 80\right)$.

Qualquer valor cuja cobrança seja atribuída por lei à União, aos Estados, ao Distrito Federal, aos Municípios e respectivas autarquias, será considerado como dívida ativa da Fazenda Pública (artigo $2^{\circ}, \S 1^{\circ}$, da Lei $n^{\circ} 6.830 / 80$ ), a qual compreenderá os créditos de natureza tributária e não tributária, abrangendo, ainda, a atualização monetária, juros e multa de mora e demais encargos previstos em lei ou contrato (artigo $2^{\circ}, \S 2^{\circ}$ da Lei $n^{\circ}$ $6.830 / 80)$.

Assim, a satisfação da dívida ativa dos entes políticos internos e respectivas autarquias pela via da execução judicial deverá se desenvolver de acordo com a Lei $\mathrm{n}^{\circ}$ 6.830/80, aplicando-se, no que esta for omissa, o Código de Processo Civil ${ }^{228}$.

A Lei $n^{\circ} 6.830 / 80$ determina, em seu artigo $8^{\circ}$, que o executado será citado para, no prazo de cinco dias, pagar a dívida com os juros e multa de mora e encargos indicados na certidão de dívida ativa, ou garantir a execução.

Em garantia à execução, prevê a Lei $n^{\circ}$ 6.830/80 que poderá o executado, em síntese, efetuar o depósito em dinheiro, oferecer fiança bancária, nomear bens à penhora ou indicar à penhora bens oferecidos por terceiros e aceitos pela Fazenda Pública (artigo $9^{\circ}$, incisos I a III).

A nomeação de bens à penhora seguirá a ordem de preferência do artigo 11 da Lei $\mathrm{n}^{\circ} 6.830 / 80$, qual seja:

(i) dinheiro;

(ii) título da dívida pública, bem como título de crédito, que tenham cotação em bolsa;

(iii) pedras e metais preciosos;

(iv) imóveis;

não usar a expressão mais simples?" (PRUDENTE, Antônio Souza. Conferência proferida no Fórum de Debates sobre a Modernização do Direito, publicado na Revista do Cento de Estudos Judiciários do Conselho da Justiça Federal, apud PAULSEN, Leandro; ÁVILA, René Bergmann; SLIWKA, Ingrid Schroder. Direito processual tributário: processo administrativo fiscal e execução fiscal à luz da doutrina e da jurisprudência. 6. ed. Porto Alegre: Livraria do Advogado, 2010. p. 145).

${ }^{228}$ Neste sentido: “A observância subsidiária das regras gerais do processo de conhecimento e das execuções postas no Código de Processo Civil somente tem cabimento quando a Lei 6.830/80 não contiver previsão sobre o tema." (ABRÃO, Carlos Henrique; ÁlVARES, Manoel; BOTESINI, Moury Ângelo; FERNANDES, Odmir; CHIMENTI, Ricardo Cunha. Lei de execução fiscal comentada e anotada. 5. ed. rev. atual. e ampl. São Paulo: Revista dos Tribunais, 2008. pág. 37). 
(v) navios e aeronaves;

(vi) veículos;

(vii) móveis ou semoventes; e

(viii) direitos e ações.

Disso emerge a questão controvertida, consistente em definir se precatório pode ser penhorado como garantia de execução fiscal, e em caso afirmativo, considerando que os bens passíveis de penhora são listados em ordem de preferência, é imperativo que se identifique em qual das hipóteses do artigo 11 da Lei $n^{\circ}$ 6.830/80 tal garantia se ajustaria.

\subsubsection{A natureza do precatório oferecido à penhora na execução fiscal}

O precatório, conforme conceito delineado no capítulo anterior, não se insere na hipótese de garantia da dívida versada no inciso II do art. 11 da Lei ${ }^{\circ}$ 6.830/80, uma vez que não é título da dívida pública com cotação em bolsa.

Também não se cogita, por óbvio, inserir o precatório nas hipóteses dos incisos III a VII do artigo 11 da Lei $n^{\circ}$ 6.830/80, quais sejam: pedra ou metal precioso, imóvel, navio e aeronave, veículo, móveis ou semoventes.

Restaria, portanto, alocá-lo como dinheiro ou direito do exequente.

Sob o regime primitivo dos precatórios, não havia dúvidas de que tais títulos não poderiam ser equiparados a dinheiro (moeda corrente).

No entanto, como já exposto acima, no tópico que tratou da utilização de precatórios no pagamento de tributos, esta situação foi sensivelmente alterada com a previsão de atribuição de "poder liberatório para pagamento de tributos" para as parcelas inadimplidas do parcelamento instituído pela Emenda Constitucional n ${ }^{\circ} 30 / 00$ (artigo 78, $\S$ $2^{\circ}$ do ADCT).

Isso porque que a expressão "poder liberatório para pagamento de tributos" contida no artigo $78, \S 2^{\circ}$ do $\mathrm{ADCT}$, foi interpretada por alguns doutrinadores como equivalente a "dinheiro", inclusive para fins de garantia da execução fiscal. 
Cite-se, a propósito, o posicionamento de Fernando Facury Scaff ${ }^{229}$, para quem o oferecimento de precatórios como garantia da execução fiscal "caracteriza-se como 'dinheiro' na forma do art. 11, I da Lei 6.830/80”, pois, segundo o citado autor, “Ao mencionar que possui poder liberatório para a quitação de tributos a Constituição fez a equiparação do precatório a dinheiro ${ }^{230}$ ".

Essa também é a posição defendida por Alexandre Macedo Tavares ${ }^{231}$, que assim leciona:

\begin{abstract}
Em razão do aludido caráter liberatório, poderá o sujeito passivo, ainda, como meio recompensatório da insubserviência da Fazenda Pública à satisfação do pagamento do precatório regularmente requisitado, opor o respectivo quantum como instrumento de penhora, equivalente a dinheiro, dotado de preferência na escala de nomeação, ex vi do inciso I do art. 655 do CPC.
\end{abstract}

Em sentido contrário, Paulo Roberto Lyrio Pimenta ${ }^{232}$, defendendo que o precatório como garantia da execução "não pode ser qualificado como dinheiro, pois não tem curso forçado".

Contudo, como adiantado no tópico em que se enfrentou a utilização de precatórios para o pagamento de tributos, a discussão sobre a natureza dos precatórios oferecidos como garantia em execução fiscal encontra-se superada, na medida em que o Superior Tribunal de Justiça definiu, de modo definitivo, no julgamento do Recurso Especial $\mathrm{n}^{\circ}$ $1.090 .898 / \mathrm{SP}^{233}$, que o precatório pode ser penhorado como direito do executado, e não como dinheiro.

Nessa assentada, discutia-se se estava correto o entendimento consignado no acórdão recorrido, proferido pelo Tribunal de Justiça de São Paulo, que decidira que "a penhora na execução fiscal, representada por máquinas da empresa executada, não poderia ser substituída por crédito de precatório, mas apenas por dinheiro ou fiança bancária quando realizada, sem o consentimento do credor".

A decisão recorrida estava fundamentada no artigo 15, inciso I da Lei ${ }^{\circ} 6.830 / 80$, que possibilita ao juiz deferir, sem a concordância da exequente, a substituição da penhora já efetivada somente por depósito em dinheiro ou fiança bancária.

\footnotetext{
${ }^{229}$ SCAFF, Fernando Facury. O uso de precatórios para pagamento de tributos. In: ROCHA, Valdir de Oliveira (coord.). Grandes questões atuais de direito tributário. v. 13. São Paulo: Dialética, 2009. p. 113.

${ }^{230}$ SCAFF, Fernando Facury. op. cit. p.113.

231 TAVARES, Alexandre Macedo. Compensação do indébito tributário. São Paulo: Dialética, 2006, p. 177178.

${ }^{232}$ In: ROCHA, Valdir de Oliveira (coord.). Grandes questões atuais de direito tributário. v. 13. São Paulo: Dialética, 2009. p.128.

${ }^{233}$ REsp 1.090.898/SP, Rel. Ministro Castro Meira, Primeira Seção, julgado em 12/08/2009, DJe 31/08/2009.
} 
E essa foi exatamente o caminho escolhido pelo Superior Tribunal de Justiça, que entendeu, encampando os argumentos do Tribunal Paulista, que:

\begin{abstract}
A Corte local decidiu em sintonia com o entendimento consolidado nesta Seção de Direito Público, a qual entende que a substituição de bem penhorado, sem a anuência do credor, somente pode ser realizada por dinheiro ou fiança bancária, não se admitindo a substituição por precatório, ainda que emitido contra a própria fazenda exequente ${ }^{234}$.
\end{abstract}

Seguindo essa linha de pensamento, o Superior Tribunal de Justiça asseverou, no mesmo julgamento, que seria válida a rejeição dos precatórios como garantia nas execuções fiscais, consignando que:

\begin{abstract}
A Primeira Seção, ao examinar o tema, concluiu que é válida a rejeição do pedido de substituição da penhora por precatório por ofensa à ordem legal dos bens penhoráveis estatuída no art. 11 da LEF, além dos arts. 655 e 656 do CPC, mediante a recusa justificada da exeqüente.
\end{abstract}

Acentuadas tais premissas, arrematou a aludida Corte Superior que "A penhora de precatório é possível, mas não como penhora de dinheiro, e sim como penhora de crédito, que figura na última posição da lista fixada no art. 11 da LEF"235.

Portanto, na esteira da jurisprudência do Superior Tribunal de Justiça, conclui-se ser admissível a penhora de precatórios em sede de execução fiscal, sendo tal garantia considerada "direito" do credor do precatório, nos termos do artigo 11, inciso VIII da Lei $\mathrm{n}^{\circ} 6.830 / 80$, e não dinheiro.

\title{
3.3.3 O problema da efetivação da garantia
}

O Superior Tribunal de Justiça privilegia a satisfação célere e efetiva da execução fiscal em detrimento ao princípio da menor onerosidade ao executado, previsto no artigo

\footnotetext{
${ }^{234}$ Ibidem. loc. cit.

${ }^{235}$ Como observado na em nota de rodapé anterior, a matéria dificilmente será reapreciada pelo Supremo Tribunal Federal, uma vez que a Corte Suprema já assentou que a discussão sobre a viabilidade de caução prestada por precatório em execução fiscal tem índole infraconstitucional, e eventual ofensa à Constituição da República se daria de modo reflexo ou indireto (AI 846268 AgR, Relatora MinistraCármen Lúcia, Primeira Turma, DJe- 17-08-2011; AI 692.326-AgR, Relator Ministro Joaquim Barbosa, Segunda Turma, DJ 03/03/2011; AI 829291 AgR, Relator Min. Gilmar Mendes, Segunda Turma, julgado em 08/02/2011, DJe- 24-02-2011; e AI 473242 AgR, Relator Min. Nelson Jobim, Segunda Turma, DJ 21-05-2004).
} 
620 do Código de Processo Civil ${ }^{236}$, determinando que, nos termos da Lei n. 6.830/80, a "execução deve ser feita no interesse do credor ${ }^{237}$ ".

Corolário disso é o posicionamento da Corte Superior de que, exceto pela impenhorabilidade do bem oferecido, pode o exequente recusar o precatório nomeado à penhora, ou ainda não aceitá-lo como substituto de um bem dado em garantia, com fundamento em qualquer das hipóteses do artigo 656 do Código de Processo Civil, ou nos artigos 11 e 15 da Lei n. 6830/80 238 . Nessa linha é a súmula 406 do STJ: “A Fazenda Pública pode recusar a substituição do bem penhorado por precatório ${ }^{239 " .}$

Logo, prestigiando a realização do crédito por meio da execução fiscal, conforme delineado pela Lei n. 6.830/80, a jurisprudência do Superior Tribunal de Justiça assegura ao exequente que a penhora recaia preferencialmente sobre dinheiro ${ }^{240}$, e seja assim mantida até o final do processo.

Corrobora a assertiva acima o entendimento da Corte Superior de que "o juiz não pode exigir do credor o exaurimento das diligências, na busca de outros bens, para a decretação da penhora online ${ }^{241}$ ", já tendo a Segunda Turma decidido que a referida medida não implica "ofensa ao princípio da menor onerosidade, previsto no art.620 do CPC, vez que tal norma jurídica deve ser interpretada sistematicamente, em consonância com as demais regras, de mesma hierarquia jurídica, que informam igualmente o procedimento de execução, a exemplo do princípio da máxima utilidade da execução ${ }^{242 \%}$.

Assim, está consolidada a possibilidade de oferecimento de precatório à penhora nas execuções fiscais, sendo, entretanto, resguardada a faculdade de o exequente recusar tal garantia, com fundamento no artigo 656 do Código de Processo Civil e artigos 11 e 15

236 “Art. 620. Quando por vários meios o credor puder promover a execução, o juiz mandará que se faça pelo modo menos gravoso para o devedor".

237 EREsp 881.014/RS, Rel. Ministro Castro Meira, Primeira Seção, DJ 17/03/2008. Ainda nessa linha: AgRg no REsp 1180646/PR, Rel. Ministra Eliana Calmon, Segunda Turma, DJe 12/08/2010.

${ }^{238}$ Nesse sentido:REsp 1090898/SP, Rel. Ministro Castro Meira, Primeira Seção, julgado em 12/08/2009, DJe 31/08/2009,EREsp 870.428/RS,AgRg nos EDcl no REsp 1255770/PR, Rel. Ministro Humberto Martins, Segunda Turma, julgado em 15/09/2011, DJe 21/09/2011, AgRg no Ag 1.281.957/RS, Rel. Ministro Castro Meira, Segunda Turma, DJe 21.5.2010; REsp 1.146.057/RS, Rel. Ministra Eliana Calmon, Segunda Turma, DJe 8.2.2010; AgRg no REsp 1.173.176/PR, Rel. Ministro Herman Benjamin, Segunda Turma, DJe 30.3.2010.

239 Súmula 406, Superior Tribunal de Justiça, Primeira Seção, DJe 24/11/2009, REPDJe 25/11/2009.

${ }^{240}$ O Superior Tribunal de Justiça, apesar de privilegiar que a penhora recaia sobre dinheiro, relativiza a ordem de preferência de bens que podem garantir a execução, sumulando o entendimento de que "Na execução civil, a penhora de dinheiro na ordem de nomeação de bens não tem caráter absoluto." (Súmula 417, Corte Especial, julgado em 03/03/2010, DJe 11/03/2010).

${ }^{241}$ REsp 1.112.943-MA, Rel. Min.NancyAndrighi, ocorrido em 15/09/2010.

${ }^{242}$ AgRg no REsp 1182130/PR, Rel. Ministro Castro Meira, Segunda Turma, julgado em 18/11/2010, DJe $01 / 12 / 2010$. 
da Lei n. 6830/80, sem que isso represente ofensa ao princípio de que a execução seja realizada de modo menos gravoso ao devedor (artigo 620 do Código de Processo Civil).

Contudo, outras questões parecem ainda não resolvidas pelo Superior Tribunal de Justiça, especialmente quando analisadas no momento da satisfação do crédito com a efetivação da penhora.

É que recaindo a penhora sobre precatórios, e considerando que tenham sido rejeitados os embargos à execução eventualmente oferecidos, ou ainda na hipótese de inexistir defesa do executado, não há certeza em se apontar a forma pela qual esta garantia deva ser efetivada.

A Primeira Seção do Superior Tribunal de Justiça consolidou o entendimento no sentido de que "a execução fiscal realiza-se no interesse do credor/exequente, cabendo-lhe, por conseguinte, escolher pela sub-rogação ou alienação judicial do direito penhorado, conforme estabelecido no art. $673, \S 1^{\circ}$, do CPC",243.

Em relação à citada escolha, “A Primeira Seção do Superior Tribunal de Justiça, ao interpretar o artigo 673, $\S 1^{\circ}$, do $\mathrm{CPC}$, firmou entendimento no sentido de que a Fazenda Pública pode preferir a alienação judicial do direito penhorado, ao invés da sub-rogação, mas deve manifestar tal vontade obrigatoriamente no prazo de 10 (dez) dias contados da realização da penhora". ${ }^{244}$

Destarte, importa analisar as duas opções de efetivação da penhora abertas à Fazenda Pública.

Na hipótese de alienação da garantia, nos termos do artigo 23 da Lei n. 6.830/80, os precatórios deveriam ser levados para leilão público, em local e data designado pelo juiz. Após o término do leilão, não havendo licitantes, a Fazenda Pública poderia adjudicar o precatório pelo preço da avaliação (artigo 24, inciso II, alínea a da Lei n. 6.830/80).

Segundo a orientação que parece se firmar no Superior Tribunal de Justiça, a efetivação da garantia, consoante as disposições da Lei de Execuções Fiscais, mostra-se desvantajosa tanto para o executado como para a própria exequente.

\footnotetext{
243 AgRg no AREsp 114.940/PR, Rel. Ministro Benedito Gonçalves, Primeira Turma, julgado em 06/03/2012, DJe 09/03/2012.

${ }^{244}$ REsp 1293506/PR, Rel. Ministro Mauro Campbell Marques, Segunda Turma, julgado em 01/03/2012, DJe 09/03/2012. Nesse sentido: EREsp 870428/RS, Rel. Min. Teori Albino Zavascki, Primeira Seção, DJ 13.8.2007, p. 328; AgRg no Ag 1415884/RS, Rel.Min. Humberto Martins, Segunda Turma, DJe 25.11.2011; AgRg no REsp 1229550/PR, Rel. Min. Castro Meira, Segunda Turma, DJe 1.7.2011; AgRg no Ag 1245632/PR, Rel. Min. Benedito Gonçalves, Primeira Turma, DJe 16.3.2011; AgRg no Ag 1235513/PR, Rel. Min. Eliana Calmon, Segunda Turma, DJe 7.6.2010.
} 
Isso porque o executado, que é credor de um precatório, ainda que na qualidade de cessionário, será obrigado a oferecê-lo à penhora pelo preço de mercado, o qual é sabidamente muito inferior ao seu valor de face, pois de acordo com entendimento firmado pelo Superior Tribunal de Justiça: “Optando a Fazenda Pública pela alienação em hasta pública de precatório penhorado em Execução Fiscal, a avaliação do bem é obrigatória, pois a sua aquisição, naturalmente, se dá por valor inferior ao nominal"245.

Assim, a orientação do Superior Tribunal de Justiça, apesar de viabilizar uma futura alienação da garantia pois atenta à realidade acerca do "mercado de precatórios", parece onerar de forma desproporcional o executado detentor de um precatório, pois, mesmo sendo ele titular de um crédito contra a Fazenda Pública, tendo o título valor de face por vezes muito superior ao exigido por meio da execução fiscal, este crédito certamente não servirá para a quitação de sua dívida tributária.

Essa crítica é feita por Sacha Calmon Navarro Côelho e Misabel Abreu Machado Derzi, que defendem que "Não faz senso penhorar um bem se ele não contiver o poder de satisfazer o crédito do accipiens ( a posteriori o precatório penhorado paga o crédito com o mesmo poder do dinheiro). Como o depósito, converte-se em pagamento, ainda que escritural. Em rigor, o que se converte em renda é o depósito em dinheiro de contado. $\mathrm{O}$ símile é perfeito ${ }^{246,}$.

De outro lado, deixando de lado a questão de ser possível ou não a Fazenda Pública adjudicar precatório, pode-se constatar que, de acordo com a interpretação dada pelo Superior Tribunal de Justiça, em praticamente nenhuma hipótese o precatório seria suficiente à satisfação do crédito tributário, na medida em que não sendo o precatório equiparável a dinheiro quando oferecido à penhora, inevitavelmente correrá contra o executado, até a data da adjudicação, a responsabilidade pela atualização monetária e juros de mora do crédito objeto da execução (artigo $9^{\circ}, \S 4^{\circ}$ da Lei n. 6.830/80 247 ) . E, tendo em vista que os precatórios são atualizados por índices bem menores que os créditos

245 REsp 1264247/RS, Rel. Ministro Herman Benjamin, Segunda Turma, julgado em 18/10/2011, DJe 25/10/2011. Na mesma direção: "Entendimento da Primeira Turma do STJ no sentido de que é legítima a avaliação dos precatórios, pleiteada pelo Estado do Rio Grande do Sul (emitidos pelo IPERGS), a fim de que se apure o seu real valor. (REsp 1.059.881/RS" (AgRg no Ag 1390102/RS, Rel. Ministro Benedito Gonçalves, Primeira Turma, julgado em 06/10/2011, DJe 11/10/2011)

246 cf. CÔELHO, Sacha Calmon Navarro; DERZI, Misabel Abreu Machado. Precatórios alimentares ofertados para garantir a execução e para pagar débitos de natureza tributária. Revista dialética de direito tributário. São Paulo, n. 144. p.104.

${ }^{247}$ Art. $9^{\circ}$ - Em garantia da execução, pelo valor da dívida, juros e multa de mora e encargos indicados na Certidão de Dívida Ativa, o executado poderá: (...) $\S 4^{\circ}$ - Somente o depósito em dinheiro, na forma do artigo 32, faz cessar a responsabilidade pela atualização monetária e juros de mora. 
tributários $^{248}$, a equivalência entre os dois será pouco provável, quiçá impossível ${ }^{249}$. Poderse-ia imaginar que a Fazenda Pública teria vantagem com o deságio obtido na avaliação do precatório, mas não se pode esquecer, de outro lado, que a penhora provavelmente será insuficiente, o que prolongará a duração do processo com vistas à satisfação do crédito tributário.

Logo, ainda que pareça ser a hasta pública o caminho mais adequado à efetiva satisfação da execução fiscal garantida por precatório, tal procedimento revela-se desvantajoso, principalmente para o executado.

Como alternativa, de acordo com a já citada jurisprudência do Superior Tribunal de Justiça, poderia ser aplicado, de forma subsidiária, o Código de Processo Civil.

Desse modo, considerado o precatório como um direito do executado, nos termos do artigo 11, inciso VIII, da Lei ${ }^{\circ}$ 6.830/80 e artigo 655, inciso XI do Código de Processo Civil, a satisfação do crédito seguiria os ditames do artigo 671 e seguintes do Código de Processo Civil, que disciplinam a penhora de créditos e de outros direitos patrimoniais.

Essa opção é defendida por Cleide Previtalli Cais ${ }^{250}$, , ponderando que, recaindo a penhora "sobre crédito do executado referente a precatório já expedido contra a exequente", deve-se obedecer aos "comandos dos arts. 671 a 676 do CPC".

Seguindo o procedimento de penhora de créditos do Código de Processo Civil, verse-á que esta deverá ser averbada no rosto dos autos em que se processa o precatório (artigo 674 do CPC). Feita a penhora no rosto dos autos, conforme ensina Araken De Assis $^{251}$, três caminhos são abertos ao exequente:
a) aguarda a solução da demanda, de olho na sub-rogação real do art. $674, \S 2^{\mathrm{a}}$ parte, para dar andamento à expropriação sobre bens - quem sabe - corpóreos e de fácil alienação;
b) promove a alienação do direito litigioso, transferindo-o a terceiro (art. $673, \S$ $\left.1^{\circ}\right)$

\footnotetext{
248 De acordo com o artigo 100, § 12 da Constituição da República (redação dada pela Emenda Constitucional $n^{\circ}$ 62/09), a atualização dos valores de requisitórios, após sua expedição, até o efetivo pagamento, independente de sua natureza, será feita pelo índice de remuneração básica da caderneta de poupança, e, para fins de compensação da mora, incidirão juros simples no mesmo percentual de juros incidentes sobre a caderneta de poupança, ficando excluída a incidência de juros compensatórios.

${ }^{249} \mathrm{O}$ mesmo problema não ocorre com a fiança bancária a qual o Superior Tribunal de Justiça confere status de dinheiro (Nesse sentido RESP 957.110/SC, ver outros). Isso porque, conforme leciona CLEIDE PREVITALLI CAIS: "Na fiança, o fiador deve assumir a responsabilidade pelo pagamento do valor da dívida original, juros e demais encargos, inclusive correção monetária, calculados até o efetivo pagamento.”(CAIS, Cleide Previtalli. O processo tributário. 7.ed..rev. atual. e ampl. São Paulo: RT, 2011. p. 599.).

${ }^{250}$ CAIS, Cleide Previtalli. O processo tributário. 7.ed..rev. atual. e ampl. São Paulo: RT, 2011. p. 606.

${ }^{251}$ Cf. ASSIS, Araken. Manual da execução. 14. ed. rev. atual. e ampl. São Paulo: RT. 2012. p.763.
} 
c) pleiteia a sub-rogação de que trata o art. 673 , caput, e substitui o executado no polo que ocupar da relação processual, observado o disposto no art. 42.

Depreende-se das lições acima que, na hipótese de ser o crédito penhorado um precatório, caberia apenas se falar em sub-rogação do ente público devedor do precatório na ação que o originou. Ocorre que não raras seriam as hipóteses em que o precatório oferecido pelo executado à penhora tenha como credor (devedor do precatório) o próprio ente federativo como exequente, ou uma ainda uma autarquia a ele pertencente.

Nessa situação, haveria um forçado encontro de contas, e a efetivação da penhora nada mais seria que verdadeira hipótese de compensação autorizada judicialmente, sem que necessariamente haja lei específica a autorizando.

Essa é a opinião de Renato de Oliveira Alves ${ }^{252}$, para quem "Ocorrendo a penhora de precatório, a situação em muito se assemelhará à de um encontro de contas (compensação), pois enquanto o credor cobra uma dívida do devedor, este garante o juízo com um crédito seu em desfavor do credor, que, no futuro, poderá servir de pagamento".

Entretanto, o Superior Tribunal de Justiça há muito sedimentou o entendimento de que não é possível a compensação de débitos tributários com créditos de precatórios, mesmo que dotados de poder liberatório para pagamento de tributos, nas hipóteses em que não há lei específica do ente federado devedor, em observância ao artigo 170 do Código Tributário Nacional ${ }^{253}$.

Nesse ponto, ao que parece, há uma incontornável incompatibilidade na jurisprudência do Superior Tribunal de Justiça.

Esse desencontro jurisprudencial é ainda mais evidente pelo fato de a jurisprudência do Superior Tribunal de Justiça permitir de um lado que a penhora recaia

${ }^{252}$ ALVES, Renato de Oliveira. Execução fiscal: comentários à Lei n. 6.830, de 22/09/1980. Belo Horizonte: Del Rey, 2008. p.102.

${ }^{253}$ Nessa trilha: "A Jurisprudência deste Tribunal Superior firme no sentido de que somente quando existe lei estadual autorizadora é possível a compensação prevista no art. 170 do CTN de débito tributário com precatório judicial". (AgRg no REsp 1285053/RS, Rel. Ministro Benedito Gonçalves, Primeira Turma, julgado em 20/03/2012, DJe 23/03/2012) e “A compensação, em matéria tributária, não se opera automaticamente, exige para sua implementação autorização em lei e a observância das demais disposições da legislação tributária quanto a condições e limites por ela admitidos. (Art. 170 do CTN)." (AgRg no AREsp 107.397/RS, Rel. Ministro Humberto Martins, Segunda Turma, julgado em 15/03/2012, DJe 23/03/2012). Por fim: "... a compensação, posto modalidade extintiva do crédito tributário (artigo 156, do CTN), exsurge quando o sujeito passivo da obrigação tributária é, ao mesmo tempo, credor e devedor do erário público, sendo mister, para sua concretização, autorização por lei específica e créditos líquidos e certos, vencidos e vincendos, do contribuinte para com a Fazenda Pública (artigo 170, do CTN)." (REsp 1.137.738/SP, Rel. Min. Luiz Fux, julgado sob o rito do art. 543-C, do CPC, DJ de 01/02/2010). 
sobre precatórios devidos por pessoas jurídicas diferentes do mesmo ente federado ${ }^{254}$, e de outro, afastar completamente a possibilidade de compensação entre débitos e precatórios devidos por pessoas jurídicas distintas, ainda que do mesmo Estado ou Município ${ }^{255}$.

Assim, não parece ser a sub-rogação uma escolha viável em qualquer execução fiscal, na medida em que devem ser observados os diversos fatores acima citados, conforme jurisprudência do próprio Superior Tribunal de Justiça.

Tais considerações sequer seriam aventadas se prevalecesse o entendimento anteriormente manifestado pela segunda turma do Superior Tribunal de Justiça ${ }^{256}$ de que:

\begin{abstract}
Um crédito sujeito a precatório não atende ao fim teleológico da praça pública. A pretensão do devedor menos não fora que, por vias obliquas, efetuar compensação de créditos entre duas obrigações heterogêneas, sem se perder de vista que, se aceita, poderia fulminar o princípio constitucional da ordem cronológica dos precatórios.
\end{abstract}

Conclui-se, portanto, que a jurisprudência do Superior Tribunal de Justiça é desarmônica ao permitir que o exequente escolha a sub-rogação como forma de satisfação do crédito objeto da execução garantida por penhora, o que se revestiria em verdadeiro procedimento de compensação, sendo que esta vedada para os casos em que não haja lei específica do ente federado.

Não há dúvida de que é interesse da Fazenda Pública liquidar o seu estoque de precatórios, inclusive com a possibilidade de serem tais créditos utilizados na quitação de débitos cobrados em execução fiscal. Porém, o que não se pode admitir é a aplicação indiscriminada desta alternativa, a qual deverá se restringir aos entes federados que já

${ }^{254}$ Cite-se: "O crédito representado por precatório é bem penhorável, mesmo que a entidade dele devedora não seja a própria exeqüente" (REsp 951.976/RS, Rel. Ministro Luiz Fux, Primeira Turma, julgado em 18/03/2008, DJe 12/05/2008) e "A jurisprudência do Superior Tribunal de Justiça é pacífica no sentido da impossibilidade de compensação de créditos tributários de ICMS com precatórios devidos por ente jurídico de natureza distinta"( AgRg no AREsp 107.397/RS, Rel. Ministro Humberto Martins, Segunda Turma, julgado em 15/03/2012, DJe 23/03/2012). "Nada impede que a penhora recaia sobre precatório cuja devedora seja outra entidade pública que não a própria exeqüente, devendo-se pôr em relevo que a penhora sobre o crédito do executado previsto em precatório obedece ao regime próprio da penhora de crédito, que indica a sub-rogação do credor no direito penhorado (AgRg no REsp $n^{\circ}$ 826.260/RS, Rel. p/Ac. Min. Teori Albino Zavascki, DJ de 07/08/2006)" (AgRg no REsp 852.425/RS, Rel. Ministro José Delgado, Rel. p/ Acórdão Ministro Francisco Falcão, Primeira Turma, julgado em 19/09/2006, DJ 14/12/2006, p. 306)

${ }^{255}$ Nesse sentido: "A primeira Seção desta Corte possui entendimento pacífico de ser inadmissível a compensação entre créditos tributários oriundos de ICMS com precatórios emitidos por Autarquia Estadual em razão da diferença de titularidade das obrigações. Precedentes: AgRg no RMS 34.021/PR, Rel. Min. CASTRO MEIRA, DJe 22/11/2011; AgRg no Ag 1.351.117/RS, Rel. Min. BENEDITO GONÇALVES, DJe 30.09.2011, e AgRg no REsp. 1.1096.680/RS, Rel. Min. HUMBERTO MARTINS, DJe 06.10.2010" (EDcl no AgRg no RMS 28.519/PR, Rel. Ministro NAPOLEÃO NUNES MAIA FILHO, PRIMEIRA TURMA, julgado em 13/03/2012, DJe 26/03/2012).

${ }^{256}$ RESp 157.913/RS, Rel. Ministro Franciulli Neto, 2002 
disciplinaram a compensação de tributos com precatórios em legislação específica, de modo a garantir maior segurança jurídica e menor onerosidade ao executado. 


\section{CONCLUSÕES}

O crédito tributário é o objeto da prestação da relação jurídico-tributária, a qual é instaurada com a verificação do fato jurídico tributário previsto no critério material do antecedente de uma regra-matriz de incidência tributária, e que terá como sujeito ativo o ente político a quem foi outorgada a competência tributária e como sujeito passivo o contribuinte, ou responsável tributário, que deverá adimplir a referida obrigação

O artigo 156 do Código Tributário Nacional estabelece doze modalidades de extinção do crédito tributários sendo elas: o pagamento, a compensação, a transação, a remissão, a prescrição, a decadência, a conversão do depósito em renda, o pagamento antecipado e a homologação do lançamento nos termos do disposto no art. 150 e seus $\S \S 1^{\circ}$ e $4^{\circ}$, a consignação em pagamento, a decisão administrativa irreformável, a decisão judicial passada em julgado e a dação de bens imóveis.

A disciplina da extinção do crédito tributário é matéria subordinada ao princípio da estrita legalidade, por expressa determinação do artigo 97, inciso VI, do Código Tributário, o que não prejudica o entendimento majoritário no sentido de que o rol do artigo 156 do Código Tributário Nacional não é exaustivo.

Levando-se em consideração o objetivo do presente trabalho, que é o de apresentar de modo sistematizado os questionamentos sobre a utilização de precatórios como forma de extinção do crédito tributário, focou-se o estudo, dentre as hipóteses de extinção do crédito tributário previstas no artigo 156 do Código Tributário Nacional, no pagamento e na compensação, por serem estas as modalidades em que se mostra possível o manejo dos precatórios.

Sobre o pagamento, viu-se que o termo é utilizado juridicamente tanto em sentido amplo, correspondendo a todo e qualquer meio de extinção de uma obrigação, como também em sentido estrito, significando a entrega de certa quantia em dinheiro ao sujeito ativo da relação obrigacional.

Ademais, concluiu-se que, em matéria tributária, o termo pagamento, previsto no artigo 156, inciso I do Código Tributário Nacional, somente pode ser entendido em seu sentido estrito, haja vista que o artigo $3^{\circ}$ do mesmo diploma legal determina que a obrigação tributária é essencialmente pecuniária, de modo que o liame obrigacional apenas 
será rompido, no pagamento, com a efetiva entrega de dinheiro, moeda corrente, aos cofres públicos (artigo 162, inciso I do Código Tributário Nacional).

Há, contudo, a possibilidade de o titular da competência tributária permitir, caso seja de seu interesse, e sempre por meio de lei, que a obrigação tributária seja adimplida pela entrega de coisa diversa de dinheiro.

Nestes casos, o termo pagamento assumirá o seu sentido amplo, de meio geral de adimplemento de obrigações, diverso do previsto no artigo 156, inciso I do Código Tributário Nacional, ainda que a lei mencione que a extinção se dará por "pagamento".

Isso porque a expressão "moeda corrente" de que se vale o artigo 162, inciso II do Código Tributário Nacional, é juridicamente definida pelo artigo $1^{\circ}$ da Lei $\mathrm{n}^{\circ} 9.069 / 95$, que estabeleceu que a partir de $1^{\circ}$ de julho de 1994 a moeda corrente com curso legal em todo o território nacional seria o REAL.

Portanto, somente haverá obrigação de natureza tributária se esta for pecuniária, bem como a extinção do liame obrigacional por meio do pagamento, nos estritos termos do artigo 156, inciso I do Código Tributário Nacional, ocorrerá apenas se o pagamento for realizado em REAL, ou seja, pelo ato de entrega de moeda corrente no território nacional pelo sujeito passivo da relação jurídico-tributária aos cofres públicos.

Em relação à compensação, deve-se, de início, ressalvar que em matéria tributária há regramento específico, diverso do aplicável para as obrigações em geral.

Com efeito, exige-se para a realização de uma compensação, no que se refere às obrigações em geral, tão somente a presença dos seguintes requisitos: reciprocidade de obrigações, liquidez de dívidas, exigibilidade das prestações e fungibilidade das coisas devidas.

Já para a efetivação de uma compensação tributária é necessário que ela esteja prevista em lei específica, editada pelo detentor da competência tributária (artigo 170 do Código Tributário Nacional), não havendo espaço para a discricionariedade da Administração Tributária. A observância à lei é estrita.

Logo, em matéria tributária não se pode falar em direito subjetivo à compensação, ao contrário, esta é um prerrogativa do legislador ordinário, que poderá criar vedações, restrições etc. 
Demais disso, o artigo 170-A do Código Tributário Nacional condiciona a compensação tributária decorrente de sentença judicial ao trânsito em julgado dessa decisão, não se admitindo mais que esta ocorra em outro momento processual.

Ainda em relação à compensação tributária, constatou-se que esta sempre esteve atrelada à repetição do indébito tributário, uma vez que, nestes casos, é inequívoca a identidade dos elementos da obrigação, e incontroversa a fungibilidade de prestações.

Essa afirmação é confirmada pela legislação federal que regulamenta a matéria, notadamente a Lei $\mathrm{n}^{\circ}$ 9.430/96.

Sem prejuízo disso, verificou-se também que o ordenamento jurídico vigente não impede sejam previstas hipóteses de compensações tributárias não vinculadas à repetição do indébito tributário, desde que estejam elas regradas em lei editada pelo ente político competente.

Dessa maneira, tais compensações tributárias dependeriam apenas da política físcal desenvolvida, a exemplo da "nota fiscal paulista" e da "nota fiscal paulistana".

De outro lado, há situações em que se tem a obrigatoriedade da realização de compensações tributárias com créditos de outra natureza, que não os oriundos de uma repetição de indébito tributário, como no caso da não cumulatividade do ICMS.

Fixadas tais premissas sobre o pagamento e a compensação como formas de extinção do crédito tributário, passou-se a investigar o conceito de precatório, sua natureza jurídica e regramento constitucional.

Verificou-se que o precatório é uma a ordem de pagar quantia certa decorrente de decisão judicial transitada em julgado contra a Fazenda Pública, emitida pelo Presidente do Tribunal nos estritos termos da solicitação a ele dirigida pelo do juízo da execução.

Estão sujeitos ao regime dos precatórios a União, os Estados, o Distrito Federal e os Municípios, suas autarquias e fundações públicas, além da Empresa Brasileira de Correios e Telégrafos - EBCT.

A sistemática de pagamento da dívida pública pelo regime de precatórios já é antiga no ordenamento jurídico brasileiro, estando prevista em sede constitucional desde a Constituição de 1934.

Atualmente, o pagamento da dívida pública decorrente de decisão judicial transitada em julgado por meio de precatório está disciplinado no artigo 100 da 
Constituição da República de 1988, com as alterações promovidas pela Emenda Constitucional n. 62/2009.

A citada Emenda Constitucional n. 62/2009 também alterou a parte transitória da Constituição da República, inserindo o artigo 97 no ADCT, que instituiu um regime especial e transitório para a quitação do estoque da dívida pública decorrente de decisões judiciais, de observância obrigatória para os entes federados que estivessem em mora no pagamento de seus precatórios vencidos e não pagos na data da promulgação da citada emenda.

Esse regime especial permitiu, em apertada síntese, que os devedores optassem pelo depósito mensal, em conta especial criada para tal fim, de quantia calculada pela aplicação de percentuais sobre as receitas correntes líquidas, ou pela adoção do regime especial pelo prazo de até 15 anos, hipótese em que o percentual a ser depositado na referida conta especial deverá corresponder, anualmente, ao saldo total dos precatórios devidos.

O regime especial do artigo 97 do ADCT objetiva saldar o estoque da dívida de precatórios existente à época em que promulgada a Emenda Constitucional n. 62/2009, tendo revogado, tacitamente, o parcelamento decenal de precatórios previsto pelo artigo 78 do ADCT, inserido pela Emenda Constitucional n. 30/2000.

O parcelamento do artigo 78 do ADCT, conforme se inferiu, foi pensado para ser uma solução de mercado para o problema da dívida pública representada por precatórios vencidos e não pagos.

Essa solução de mercado seria possível pela conjunção da previsão do artigo 78, caput, do ADCT, que permitiu a cessão de créditos de precatórios, com o parágrafo segundo, também do artigo 78 do ADCT, que estabeleceu que as prestações desse parcelamento que não fossem liquidadas até o final do exercício financeiro a que se referiam, teriam poder liberatório do pagamento de tributos da entidade devedora.

Ocorre que, como demonstrado, a possibilidade de se atribuir poder liberatório aos precatórios sujeitos ao parcelamento do artigo 78 do ADCT que não tivessem suas parcelas adimplidas, e a permissão de que tais créditos de precatórios fossem cedidos, provocaram uma série de questionamentos judiciais e doutrinários sobre o modo pelo qual tais precatórios poderiam ser utilizados como forma de extinção de créditos tributários.

Nesse ponto, e forte nas premissas estabelecidas sobre o pagamento e a compensação em matéria tributária, passou-se a enfrentar a hipótese que serviu para o 
desenvolvimento do presente estudo, a saber: é possível a utilização de precatórios como forma de extinção de créditos tributários? Em que situações?

De início, pode-se afastar de uma vez a possibilidade de utilização de um precatório como "moeda" para o pagamento de um tributo, nos termos do artigo 156, inciso I do CTN.

Com efeito, deduziu-se que a obrigação tributária é estritamente pecuniária, bem como que o termo pagamento é adotado pelo Código Tributário Nacional em seu sentido estrito, correspondente à entrega de dinheiro - moeda corrente-, aos cofres públicos.

Ademais, depreendeu-se que moeda é termo juridicamente definido, apresentando as seguintes características:

(i) ser bem fungível, podendo ser tocado por outro de mesma qualidade, quantidade e espécie;

(ii) ter sido determinado pelo Direito, na medida em que só poderá ser considerado moeda aquilo que o Direito disser que é;

(iii) ser aceito de forma universal pela sociedade, ou seja, a moeda é o instrumento ordinário de efetivação do pagamento e correspondente extinção da relação obrigacional;

(iv) representar sempre uma unidade ideal de medida, representativa de valores dos bens e serviços existentes no mercado; e

(v) ser o instrumento utilizado por toda a sociedade como elemento de extinção das relações de caráter pecuniário.

Entretanto, como restou deduzido, tais elementos não são encontrados nos precatórios, mesmo os que são dotados de poder liberatório para o pagamento de tributos.

Essa é a consolidada jurisprudência do Superior Tribunal de Justiça.

E, por se concluir que o precatório, ainda que dotado de poder liberatório para o pagamento de tributos, não poderia ser equiparado à moeda, impedindo-se, assim, a sua utilização como instrumento próprio para o pagamento de tributos, direcionou-se a pesquisa para a possibilidade de utilização de precatórios em procedimento de compensação tributária.

Nesse ponto, a matéria foi analisada de forma compartimentada. 
Iniciou-se pela compensação de créditos tributários com precatórios que não fossem dotados constitucionalmente de poder liberatório para o pagamento de tributos. Nessa situação, pode-se concluir que bastaria a edição de uma lei específica pelo detentor da competência tributária, que fosse ao mesmo tempo devedor do tributo, constando nessa lei a previsão de todos os requisitos necessários à compensação tributária.

Nessa linha, foi citada a Lei $\mathrm{n}^{\circ} 10.339 / 1999$ do Estado de São Paulo, que disciplinou a compensação de créditos tributários com precatórios, sem que estes precatórios tivessem força liberatória para o pagamento de tributos constitucionalmente determinada.

Na sequência, analisou-se a compensação de tributos com precatórios, fundada no artigo 78, $\S 2^{\circ}$, do ADCT.

Dessa análise, depreendeu-se que o artigo 78, § $2^{\circ}$, do ADCT é uma norma constitucional de eficácia limitada, pois dependeria da edição de uma outra norma para que seus efeitos pudessem ser produzidos.

A partir disso, concluiu-se que a exigência do artigo 170 do CTN não pode ser afastada nas hipóteses em que se pretenda compensar um crédito tributário com os precatórios referidos no artigo $78, \S 2^{\circ}$, do ADCT, uma vez que à lei caberia disciplinar os requisitos indispensáveis para a efetivação dessa modalidade de compensação, notadamente o modo pelo qual se observariam a ordem cronológica de pagamento dos tributos e as vinculações constitucionais das receitas obtidas pelo recolhimento do imposto.

Essa também é a linha seguida pelo Superior Tribunal de Justiça.

O artigo 78 do ADCT suscitou ainda outras duas discussões, a primeira decorre da tese que defende a aplicabilidade do parcelamento estabelecido nesse dispositivo constitucional também para os precatórios alimentares.

Referida discussão surge do fato de que a Emenda Constitucional n. 30 de 2000 expressamente excluiu os precatórios alimentares do parcelamento por ela instituído, partindo, ao que tudo indica, do pressuposto de que os precatórios alimentares, que tinham ordem cronológica de pagamento distinta dos precatórios comuns, estavam sendo regularmente quitados, inclusive em prazo menor que aqueles.

Entretanto, a premissa se mostrou equivocada, e os precatórios alimentares hoje representam a maior parte do estoque de precatórios, sobretudo no Estado de São Paulo. 
Todavia, em virtude da existência da expressa previsão constitucional, não há como se autorizar a aplicação das regras do artigo 78 do ADCT aos precatórios alimentares. Essa é a posição do Superior Tribunal de Justiça.

Esse posicionamento poderá ser revisto, uma vez que a matéria ainda será decidida de forma definitiva pelo Supremo Tribunal Federal nos autos do recurso extraordinário 566.349, que teve repercussão geral reconhecida.

A outra discussão envolvendo o artigo 78 do ADCT diz respeito ao conceito de “entidade devedora", contido no caput para fins de compensação.

A tese levada aos Tribunais é a de que não se poderia obstar a realização de uma compensação de precatórios de uma autarquia com créditos tributários do ente federado ao qual a autarquia estava vinculada.

Nessa parte, constatou-se que uma autarquia, instituída por lei, tem personalidade jurídica própria, distinta do ente federado ao qual ela está vinculada, além de possuir patrimônio próprio e autoadministração.

Como visto, tais características imporiam à autarquia a responsabilidade por seus débitos, os quais não poderiam ser imputados ao ente federado ao qual ela está vinculada, muito menos para fins de compensação.

Nessa trilha são as decisões do Superior Tribunal de Justiça.

Ainda em relação ao artigo 78 do ADCT, citou-se que este dispositivo está com sua exigibilidade suspensa em razão da medida cautelar deferida nos autos da Ação Direta de Inconstitucionalidade n. 2356, além de ter sido tacitamente revogado pelo artigo 97 do ADCT, inserido pela Emenda Constitucional n. 62/2009.

Não obstante isso, reiterou-se a relevância do seu estudo, a uma porque encontramse pendentes de julgamento no Supremo Tribunal Federal recursos extraordinários que versam sobre o artigo 78 do ADCT, inclusive com repercussão geral reconhecida (e.g.RE 566.349 e RE 597.092). A duas, pelo fato de que a própria Emenda Constitucional n. 62/2009 é questionada em diversas Ações Diretas de Inconstitucionalidade, como as Ações Diretas de Inconstitucionalidade $\mathrm{n}^{\circ} 4.357,4.372,4.400$ e 4.425 .

Em relação à Emenda Constitucional 62/2009, foram objeto de estudo as duas espécies de compensações por ela instituída, a primeira, prevista no artigo $100, \S \S 9^{\circ}$ e 10 da Constituição da República, que trata da compensação realizada no interesse da Fazenda Pública, antes da expedição do precatório, e a segunda, prevista no artigo 97, § 10, inciso II 
do ADCT, que é uma espécie de sanção que pode ser ordenada pelo Presidente do Tribunal para o ente federativo que não honrar os depósitos mensais do regime especial de que trata o artigo 97 do ADCT.

Sobre a compensação sanção, pode-se inferir que esta independe de lei por expressa determinação constitucional, motivo pelo qual deverá conter a ordem emitida pelo Presidente do Tribunal todos os requisitos necessários à compensação. Nesta hipótese, não há restrição quanto aos créditos alimentares e cessões de crédito.

Já a compensação que é facultada à Fazenda Pública antes da expedição do precatório, embora independa de regulamentação, foi disciplinada pela Resolução 115/2010 do CNJ e, em âmbito federal, pela Lei n. 12431/2011.

Essa modalidade de compensação só é aplicável aos credores originais dos precatórios que serão expedidos.

Assim, no momento da expedição do precatório, a Fazenda Pública é intimada para indicar eventuais débitos inscritos ou não em dívida ativa daquele que será titular de um precatório, para que seja realizado o procedimento de compensação, tratado pela Constituição Federal como um "abatimento". Caso não sejam informados os débitos, a fazenda perderá o direito de abatimento do precatório, restando a cobrança pelos demais meios a ela disponíveis. Poderão ser compensados apenas os débitos tributários que não estejam com a sua exigibilidade suspensa, ou os créditos tributários que estejam parcelados, desde que seja ele ordinário, regular, e não os parcelamentos incentivados, que oferecem benefícios e impõe condições aos contribuintes.

Essa compensação, nos termos das normas que a regulamentam, será considerada realizada no momento da expedição do precatório, efetivando-se, contudo, no momento do pagamento do precatório, dentro da sua ordem cronológica.

De todo o exposto, pode-se afirmar que é possível a utilização de precatórios como forma de extinção de créditos tributários em procedimento de compensação, ressalvandose, entretanto, que os requisitos necessários para sua realização devem estar previstos em lei específica, ou na própria Constituição, salvo se houver expressa determinação constitucional atribuindo essa função a uma ordem judicial.

No que se refere à utilização de precatórios como garantia da execução fiscal, verifica-se que tal expediente não é vedado pela legislação de regência, sendo essa possibilidade corroborada pelo Superior Tribunal de Justiça, o qual, contudo, classifica 
essa garantia apenas como um "direito" do credor do precatório, nos termos do artigo 11, inciso VIII da Lei ${ }^{\circ} 6.830 / 80$, e não dinheiro.

Não sendo o precatório equiparável a dinheiro quando oferecido à penhora, e também seguindo orientação consolidada pelo Superior Tribunal de Justiça, este deve ser oferecido pelo seu valor de mercado e não de face, o que, apesar de viabilizar a sua alienação, causa evidente prejuízo ao executado.

De outro lado, também por não se considerar precatório como dinheiro, ou ainda equivalente à carta de fiança bancária, não se admite a simples extinção da dívida garantida pelo precatório como se depósito judicial fosse, correndo contra o executado, até a data da adjudicação, a responsabilidade pela atualização monetária e juros de mora do crédito objeto da execução (artigo $9^{\circ}, \S 4^{\circ}$ da Lei n. 6.830/80), sendo, portanto, inviável a equivalência entre a atualização do crédito tributário e do precatório, tornando muito pequena a possibilidade de um precatório ser apto a quitar uma dívida tributária.

Por fim, caso o exequente aceite que a penhora recaia sobre precatórios e escolha de efetivação dessa penhora nos moldes do artigo 671 e seguintes do Código de Processo Civil, ainda na esteira da jurisprudência do Superior Tribunal de Justiça, a sub-rogação prevista no artigo 673, caput, do Código de Processo Civil seria, na prática, verdadeira compensação tributária autorizada judicialmente sem que, em muitos casos, haja lei específica, em notória afronta ao artigo 170 do Código Tributário Nacional, além de possivelmente envolver créditos alimentares e de entidades diferentes, modalidades em que a Corte Superior não permite a compensação.

Portanto, concluiu-se, nesse ponto, que a penhora sobre precatórios deve ser autorizada somente nas hipóteses em que seja possível a posterior compensação, assegurando-se, assim, a efetiva satisfação do crédito tributário. 


\section{BIBLIOGRAFIA}

ABRAHAM, Marcus. Reflexões sobre a EC 62/2009: a compensação de precatórios com créditos da fazenda pública. Revista tributária e de finanças públicas. São Paulo: Revista dos Tribunais, a. 18, n. 94, set.-out. 2010.

ABRÃO, Carlos Henrique; ÁLVARES, Manoel; BOTESINI, Moury Ângelo; FERNANDES, Odmir; e CHIMENTI, Ricardo Cunha. Lei de execução fiscal comentada e anotada, 5. ed., rev. atual. e ampl. São Paulo: Revista dos Tribunais, 2008.

ALVES, Renato de Oliveira. Execução fiscal: comentários à lei n. 6830, de 22/09/1980. Belo Horizonte: Del Rey, 2008.

ATALIBA, Geraldo. Hipótese de incidência tributária. 6. ed., 5. tirag. São Paulo: Malheiros, 2004.

ASSIS, Araken de. Manual da execução. 14. ed. rev. atual. e ampl. São Paulo: RT, 2012.

BARROSO, Luís Roberto. Interpretação e aplicação da constituição. São Paulo: Saraiva, 2004.

BECKER, Alfredo Augusto. Teoria geral do direito tributário. 5. ed. São Paulo: Noeses, 2010.

BITTAR, Eduardo C. B. Metodologia da pesquisa jurídica: teoria e prática da monografia para os cursos de direito. 8. ed. São Paulo: Saraiva, 2010.

BORGES, José Souto Maior. Obrigação tributária: uma introdução metodológica. 2. ed. São Paulo: Malheiros Editores.

CAETANO, Marcello. Princípios fundamentais de direito administrativo. Rio de Janeiro: Forense, 1989.

CAIS, Cleide Previtalli. O Processo tributário. 7. ed. rev. atual. e ampl. São Paulo: RT, 2011 
CARRAZZA, Roque Antonio. ICMS. 14. ed. São Paulo: Malheiros, 2009.

CARVALHO, André Castro. Vinculação de receitas públicas. São Paulo: Quartier Latin, 2010.

CARVALHO, Paulo de Barros. Teoria da norma tributária. Max Limonad, 4. ed. São Paulo, 2002.

Curso de direito tributário. 22. ed. São Paulo: Saraiva, 2010.

CERQUEIRA, Marcelo Fortes de. Extinção da obrigação tributária: compensação e repetição do indébito. In: Curso de especialização em direito tributário: estudos analíticos em homenagem a Paulo de Barros Carvalho. Rio de Janeiro: Forense, 2005.

COÊLHO, Sacha Calmon Navarro. Liminares e depósitos antes do lançamento por homologação: decadência e prescrição. 2. ed. São Paulo: Dialética, 2002.

Curso de direito tributário. 11. ed. Rio de Janeiro: Forense, 2010.

CÔELHO, Sacha Calmon Navarro; DERZI, Misabel Abreu Machado. Precatórios, tributos e a emenda constitucional $\mathrm{n}^{\circ}$ 62/2009. Revista dialética de direito tributário. São Paulo, n. 180, 2010. [p. 182-191].

- Precatórios alimentares ofertados para garantir a execução e para pagar débitos de natureza tributária. Revista dialética de direito tributário. São Paulo, n. 144. set. 2007.

CONRADO, Paulo Cesar. Compensação tributária e processo. 2. ed. São Paulo: Quartier Latin, 2010.

CONTI, José Maurício. Dívida pública e responsabilidade físcal no federalismo brasileiro. In: SCHOUERI, Luís Eduardo (Org.). Direito tributário: estudos em homenagem ao prof. Alcides Jorge Costa. São Paulo: Quartier Latin, 2003. [v. 2, p. 1077-1093].

COSTA, Regina Helena. Curso de direito tributário: constituição e código tributário nacional. São Paulo: Saraiva, 2009. 
CRETELLA JÚNIOR, José. O contencioso administrativo na constituição de 1969. Revista de direito administrativo. v. 104, p. 30-48, Rio de Janeiro: Fundação Getúlio Vargas, 1971.

CUNHA, Leonardo José Carneiro da. A fazenda pública em juízo. 8. ed. São Paulo: Dialética, 2010.

DANTAS, Francisco Wildo Lacerda. Execução contra a fazenda pública: regime de precatório. 2. ed. São Paulo: Método, 2010.

DAVI, René. O Direito Inglês. [título original: Le Droit Anglais]. Tradução de Eduardo Brandão. São Paulo: Martins Fontes, 1997.

DI PIETRO, Maria Sylvia Zanella. Direito administrativo. 23. ed. São Paulo: Atlas, 2010.

DIDIER JUNIOR, Fredie; CUNHA, Leonardo José Carneiro da; BRAGA, Paula Sarno; OLIVEIRA, Rafael. Curso de direito processual civil: execução. 4. ed. v. 5. Salvador: Jus Podium, 2012.

DINIZ, Maria Helena. Curso de direito civil brasileiro: teoria geral das obrigações. v. 2: São Paulo: Saraiva, 2011.

ECO, Umberto. Como se faz uma tese. [título original: Come si fa uma tesi de láurea, 1932]. Tradução de Gilson Cesar Cardoso de Souza. 23. ed. São Paulo: Perspectiva, 2010.

FERRAZ, Roberto. O pagamento de tributos com precatórios: caso de uso de moeda e não de compensação: a inconstitucionalidade dinâmica da vedação à compensação. In: ROCHA, Valdir de Oliveira. Grandes questões atuais do direito tributário v. 13. São Paulo: Dialética, 2009 [p. 344-356].

FERREIRA, Eudimar Alves. Um estudo sobre a compensação tributária. In: SCAFF, Fernando Facury (coord.). Direito tributário e financeiro aplicado. São Paulo: Quartier Latin, 2010.

FLAKS, Milton. Precatório judiciário na constituição de 1988. Revista de processo n. 58, a. 15, São Paulo: RT, 1990. 
FREDERIGHI, Wanderley José. A execução contra a fazenda pública. São Paulo: Saraiva, 1996.

GRUPENMACHER, Betina Treiger. O uso de precatórios para pagamento de tributos. Revista dialética de direito tributário. São Paulo, n. 175, p. 34-55, 2010.

HORVATH, Estevão. Lançamento tributário e "autolançamento". São Paulo: Dialética, 1997.

JUSTEN FILHO, Marçal; NASCIMENTO, Carlos Valder do. Emenda dos precatórios: fundamentos de sua inconstitucionalidade. Belo Horizonte: Fórum, 2010.

LOCKMANN, Ana Paula Pellegrina. A execução contra a fazenda pública: precatórios trabalhistas. São Paulo: LTr, 2004.

MACHADO, Hugo de Brito. Comentários ao código tributário nacional. v. III. São Paulo: Atlas, 2005.

. Curso de direito tributário, 31. ed. São Paulo: Malheiros, 2010.

MALERBI, Diva Prestes Marcondes. A cláusula pétrea da legalidade tributária e o instituto da compensação. Revista de direito tributário. n. 67, São Paulo: Malheiros, 1995.

MARINONI, Luiz Guilherme; MITIDIERO, Daniel. Código de processo civil comentado artigo por artigo. 2 ed. São Paulo: Revista dos Tribunais, 2010.

MEDAUAR, Odete. Direito administrativo moderno. 14. ed. rev. e atual. São Paulo: Revista dos Tribunais, 2010.

MELLO, José Eduardo de. Curso de direito tributário. 7. ed. São Paulo: Dialética, 2007.

MORAES, Alexandre de. Direito constitucional. 28. ed. São Paulo: Atlas, 2012.

MOSQUERA, Roberto Quiroga. Direito monetário e tributação da moeda. São Paulo: Dialética; Oliveira Rocha, 2006. 
NOGUEIRA, Ruy Barbosa. Curso de direito tributário. [edição do autor] 4. ed. São Paulo: Instituto Brasileiro de Direito Tributário, 1976.

OLIVEIRA, Regis Fernandes de. Manual de direito financeiro. 6. ed. São Paulo: Revista dos Tribunais, 2009.

PAULSEN, Leandro. Curso de direito tributário. Porto Alegre: Livraria do Advogado, 2008 .

PAULSEN, Leandro, ÁVILA, René Bergmann, SLIWKA, Ingrid Schroder. Direito processual tributário: processo administrativo fiscal e execução fiscal à luz da doutrina $\mathrm{e}$ da jurisprudência. 6. ed. Porto Alegre: Livraria do Advogado, 2010.

PIMENTA, Paulo Roberto Lyrio. O Pagamento de tributos por meio de créditos relativos aos precatórios judiciais. Revista dialética de direito tributário. São Paulo, n. 177, p. 121-129, 2010.

RACT, Artur Ricardo. Precatórios: a compensação de tributos federais com o advento da Lei 12.431/2011. Revista tributária e de finanças públicas. São Paulo: RT, a. 19, n. 10, set. -out., 2011.

RAFAELLI, Paulo Cesar Pimentel. Compensação de tributos com precatórios. Revista tributária e de finanças públicas. São Paulo: RT, n. 78, a. 16, jan.-fev., 2008.

TAVARES, Alexandre Macedo. Compensação do indébito tributário. São Paulo: Dialética, 2006.

SANTI, Eurico Marcos Diniz de. Lançamento tributário. 3. ed. São Paulo, Saraiva, 2010.

SANTOS, Bruno Maciel dos. O precatório como garantia da execução fiscal à luz da atual jurisprudência do superior tribunal de justiça. Revista dialética de direito tributário. São Paulo, n. 203, p. 54-64, 2012.

SCAFF, Fernando Facury. O uso de precatórios para pagamento de tributos. In: ROCHA, Valdir de Oliveira (coord.). Grandes questões atuais de direito tributário. v. 13. São Paulo: Dialética, 2009 [p. 102-116]. 
dialética de direito tributário. São Paulo, n. 175, abr. 2010.

2010 . . (coord.). Direito tributário e financeiro aplicado. São Paulo: Quartier Latin,

SCHOUERI, Luís Eduardo. Direito tributário. São Paulo: Saraiva, 2011.

Fato gerador da obrigação tributária. In: Luis Eduardo Schoueri. (Org.). Direito tributário: homenagem a Alcides Jorge Costa. São Paulo: v. 1. Quartier Latin, 2003. [p. 125-168].

SILVA, Américo Luís Martins da. Precatório-requisitório e requisição de pequeno valor (RPV). 4. ed. atual. e ampl. São Paulo: RT, 2010.

SILVA, José Afonso da. Curso de direito constitucional positivo. 26. ed., São Paulo: Malheiros, 2006.

SILVA, Ricardo Perlingeiro Mendes da. Execução contra a fazenda pública. São Paulo: Malheiros, 1999.

SILVEIRA, Vladmir Oliveira da Silveira; CONTIPELLI, Ernani. Pagamento de tributos com precatórios judiciais em mora da Fazenda Pública. Revista tributária e de finanças públicas. São Paulo: RT, n. 84, a. 17, jan.-fev., 2009.

TEODORO JUNIOR, Humberto. Comentários ao código de processo civil. v. 4. Rio de Janeiro: Forense, 1979.

Lei de execução fiscal: comentários e jurisprudência. 12. ed. São Paulo: Saraiva, 2011.

VAZ, José Otávio de Vianna. O pagamento de tributos por meio de precatórios. Belo Horizonte: Del Rey, 2007.

VAZ, Orlando, coordenador. Precatórios: problemas e soluções. Belo Horizonte: Del Rey, 2005.

VENOSA, Sílvio de Salvo. Direito civil: teoria geral das obrigações e teoria geral dos 
contratos. 12. ed. São Paulo: Atlas, 2012.

VIANA, Juvêncio Vasconcelos. Execução contra a fazenda pública. São Paulo: Dialética, 1998. 


\begin{abstract}
ANEXO
RELAÇÃO DOS PROCESSOS, POR CÂMARA JULGADORA E DATA DE JULGAMENTO, EM QUE FORAM PROFERIDOS OS ACÓRDÃOS DO TRIBUNAL DE JUSTIÇA DE SÃO PAULO QUE SERVIRAM DE SUPORTE PARA A ELABORAÇÃO DOS GRÁFICOS SOBRE A UTILIZAÇÃO DE PRECATÓRIOS PARA FINS TRIBUTÁRIOS
\end{abstract}

- Processo nº 0064705-27.2011.8.26.0000, Órgão Especial, Relator Mário Devienne Ferraz, julgado em 16 de novembro de 2011;

- Processo $n^{\circ}$ 0074431-25.2011.8.26.0000, Órgão Especial, Relator Samuel Júnior, julgado em 14 de dezembro de 2011;

- Processo $n^{\circ}$ 0230854-81.2009.8.26.0000, Órgão Especial, Relator A.C. Mathias Coltro, julgado em 02 de março de 2011;

- Processo $n^{0}$ 9088095-38.2009.8.26.0000, $1^{\text {a }}$ Câmara de Direito Público, Relator Vicente de Abreu Amadei, julgado em 29 de novembro de 2011;

- Processo $n^{\mathrm{o}}$ 0045234-94.2010.8.26.0053, $1^{\mathrm{a}}$ Câmara de Direito Público, Relator Danilo Panizza, julgado em 25 de outubro de 2011;

- Processo $n^{\circ}$ 0066113-53.2011.8.26.0000, $1^{\mathrm{a}}$ Câmara de Direito Público, Relatora Regina Capistrano, julgado em 08 de novembro de 2011;

- Processo $n^{0}$ 0008841-57.2010.8.26.0220, $1^{\mathrm{a}}$ Câmara de Direito Público, Relator Márcio Franklin Nogueira, julgado em 25 de outubro de 2011;

- Processo $\mathrm{n}^{\mathrm{o}}$ 0487867-20.2010.8.26.0000, $1^{\mathrm{a}}$ Câmara de Direito Público, Relator Castilho Barbosa, julgado em 07 de junho de 2011;

- Processo $n^{\mathrm{o}}$ 0099182-76.2011.8.26.0000, 2 $2^{\mathrm{a}}$ Câmara de Direito Público, Relator José Luiz Germano, julgado em 16 de outubro de 2011;

- Processo $n^{\mathrm{o}}$ 0188954-50.2011.8.26.0000, $2^{\mathrm{a}}$ Câmara de Direito Público, Relatora Vera Angrisani, julgado em 06 de dezembro de 2011;

- Processo $n^{\mathrm{o}}$ 0077720-63.2011.8.26.0000, 2a Câmara de Direito Público, Relator Lineu Peinado, julgado em 29 de novembro de 2011; 
- Processo $n^{\mathrm{o}}$ 0101579-11.2011.8.26.0000, 2a Câmara de Direito Público, Relator Samuel Júnior, julgado em 27 de setembro de 2011;

- Processo $\mathrm{n}^{\mathrm{o}}$ 0032276-76.2010.8.26.0053, $2^{\mathrm{a}}$ Câmara de Direito Público, Relator Corrêa Vianna, julgado em 22 de março de 2011;

- Processo $n^{0}$ 0025276-33.2009.8.26.0482, $2^{\mathrm{a}}$ Câmara de Direito Público, Relator Henrique Nelson Calandra, julgado em 14 de dezembro de 2010;

- Processo $n^{0}$ 0267517-92.2010.8.26.0000, $3^{\mathrm{a}}$ Câmara de Direito Público, Relator Antonio Carlos Malheiros, julgado em 13 de dezembro de 2011;

- Processo $n^{0}$ 0096496-14.2011.8.26.0000, $3^{\mathrm{a}}$ Câmara de Direito Público, Relator Leonel Costa, julgado em 29 de novembro de 2011;

- Processo $n^{0}$ 0203135-56.2011.8.26.0000, $3^{\mathrm{a}}$ Câmara de Direito Público, Relator Amorim Cantuária, julgado em 17 de janeiro de 2012;

- Processo $n^{\circ}$ 0190718-71.2011.8.26.0000, $3^{\mathrm{a}}$ Câmara de Direito Público, Relator Marrey Uint, julgado em 20 de setembro de 2011;

- Processo $n^{0}$ 0033661-93.2009.8.26.0053, $3^{\text {a }}$ Câmara de Direito Público, Relator Angelo Malanga, julgado em 06 de setembro de 2011;

- Processo $n^{\circ}$ 0021069-80.2010.8.26.0053, $4^{\mathrm{a}}$ Câmara de Direito Público, Relator Rui Stoco, julgado em 05 de dezembro de 2011;

- Processo $n^{0}$ 9246979-05.2008.8.26.0000, 4 Câmara de Direito Público, Relator Ferreira Rodrigues, julgado em 14 de março de 2011;

- Processo $\mathrm{n}^{\mathrm{o}}$ 0080951-74.2006.8.26.0000, 4a Câmara de Direito Público, Relatora Ana Luiza Liarte, julgado em 22 de agosto de 2011;

- Processo $n^{0}$ 0143899-52.2006.8.26.0000, $4^{\mathrm{a}}$ Câmara de Direito Público, Relator Osvaldo Magalhães, julgado em 03 de outubro de 2011;

- Processo $n^{o}$ 0003989-40.2009.8.26.0053, 5 Câmara de Direito Público, Relator Franco Cocuzza, julgado em 05 de dezembro de 2011;

- Processo $n^{0}$ 0007731-05.2011.8.26.0053, 5 Câmara de Direito Público, Relator Francisco Bianco, julgado em 05 de dezembro de 2011;

- Processo $n^{0}$ 0024853-65.2010.8.26.0053, $5^{\mathrm{a}}$ Câmara de Direito Público, Relator Nogueira Diefenthaler, julgado em 10 de outubro de 2011;

- Processo $n^{\mathrm{o}}$ 0269560-65.2011.8.26.0000, 5 Câmara de Direito Público, Relatora Maria Laura Tavares, julgado em 21 de novembro de 2011; 
- Processo $n^{\circ}$ 0089886-45.2002.8.26.0000, 5ª Câmara de Direito Público, Relator Fermino Magnani Filho, julgado em 16 de maio de 2011;

- Processo $n^{\circ}$ 0005319-04.2011.8.26.0053, 6 Câmara de Direito Público, Relator Oliveira Santos, julgado em 05 de dezembro de 2011;

- Processo $n^{\circ}$ 0010810-89.2011.8.26.0053, 6 $6^{\mathrm{a}}$ Câmara de Direito Público, Relator Leme de Campos, julgado em 05 de dezembro de 2011;

- Processo $n^{0}$ 9000186-70.2011.8.26.0037, 6a Câmara de Direito Público, Relator Carlos Eduardo Pachi, julgado em 24 de outubro de 2011;

- Processo $n^{o}$ 0004835-97.2011.8.26.0114, 6 Câmara de Direito Público, Relator Evaristo dos Santos, julgado em 21 de novembro de 2011;

- Processo $n^{0}$ 0033683-31.2010.8.26.0405, 6 Câmara de Direito Público, Relator Reinaldo Miluzzi, julgado em 28 de novembro de 2011;

- Processo $n^{0}$ 9215452-40.2005.8.26.0000, 6 $6^{\mathrm{a}}$ Câmara de Direito Público, Relator Sidney Romano dos Reis, julgado em 26 de outubro de 2009;

- Processo $n^{o}$ 0006136-68.2011.8.26.0053, $7^{\mathrm{a}}$ Câmara de Direito Público, Relator Moacir Peres, julgado em 05 de dezembro de 2011;

- Processo $n^{0}$ 0033327-25.2010.8.26.0053, $7^{\mathrm{a}}$ Câmara de Direito Público, Relator Magalhães Coelho, julgado em 07 de novembro de 2011;

- Processo $n^{0}$ 0000564-97.2011.8.26.0032, $7^{\mathrm{a}}$ Câmara de Direito Público, Relator Coimbra Schmidt, julgado em 07 de novembro de 2011;

- Processo $n^{0}$ 0199603-74.2011.8.26.0000, $7^{\mathrm{a}}$ Câmara de Direito Público, Relator Eduardo Gouvêa, julgado em 24 de outubro de 2011;

- Processo $n^{\mathrm{o}}$ 0190611-27.2011.8.26.0000, $7^{\mathrm{a}}$ Câmara de Direito Público, Relator Guerrieri Rezende, julgado em 10 de outubro de 2011;

- Processo $n^{\circ}$ 0252621-10.2011.8.26.0000, $8^{\mathrm{a}}$ Câmara de Direito Público, Relator Osni de Souza, julgado em 14 de dezembro de 2011;

- Processo $n^{0}$ 0270304-31.2009.8.26.0000, $8^{\mathrm{a}}$ Câmara de Direito Público, Relator Rubens Rihl, julgado em 16 de novembro de 2011;

- Processo $n^{0}$ 0009596-28.2011.8.26.0000, $8^{\mathrm{a}}$ Câmara de Direito Público, Relator João Carlos Garcia, julgado em 25 de maio de 2011;

- Processo $n^{\circ}$ 0085598-17.2009.8.26.0224, $8^{\mathrm{a}}$ Câmara de Direito Público, Relatora Cristina Cotrofe, julgado em 09 de novembro de 2011; 
- Processo $n^{\circ}$ 9136297-46.2009.8.26.0000, $8^{\text {a }}$ Câmara de Direito Público, Relator Carvalho Viana, julgado em 07 de abril de 2010;

- Processo $n^{o}$ 9217393-20.2008.8.26.0000, $8^{\text {a }}$ Câmara de Direito Público, Relator Paulo Dimas Mascaretti, julgado em 27 de maio de 2009;

- Processo $n^{0}$ 0029916-08.2009.8.26.0053, 9ª Câmara de Direito Público, Relator Paulo Sérgio Gomes, julgado em 14 de dezembro de 2011;

- Processo $n^{0}$ 0012983-54.2009.8.26.0248, 9a Câmara de Direito Público, Relator Oswaldo Luiz Palu, julgado em 16 de dezembro de 2011;

- Processo $n^{\circ}$ 0225931-41.2011.8.26.0000, 9ª Câmara de Direito Público, Relator Décio Notarangeli, julgado em 16 de dezembro de 2011;

- Processo $n^{0}$ 0026057-47.2010.8.26.0053, 9a Câmara de Direito Público, Relator Antonio Rulli Júnior, julgado em 06 de julho de 2011;

- Processo $n^{\circ}$ 0170542-71.2011.8.26.0000, 9ª Câmara de Direito Público, Relator Rebouças de Carvalho, julgado em 16 de novembro de 2011;

- Processo $n^{0}$ 0005649-98.2011.8.26.0053, $10^{\text {a }}$ Câmara de Direito Público, Relator Antonio Carlos Villen, julgado em 19 de dezembro de 2011;

- Processo $n^{\circ}$ 0039180-15.2010.8.26.0053, $10^{\mathrm{a}}$ Câmara de Direito Público, Relator Paulo Galizia, julgado em 21 de novembro de 2011;

- Processo $n^{\circ}$ 0080215-80.2011.8.26.0000, $10^{\mathrm{a}}$ Câmara de Direito Público, Relator Teresa Ramos Marques, julgado em 21 de novembro de 2011;

- Processo $n^{0}$ 0070084-97.2008.8.26.0114, 10ª Câmara de Direito Público, Relator Torres de Carvalho, julgado em 21 de novembro de 2011;

- Processo $n^{\circ}$ 0224001-85.2011.8.26.0000, $10^{\mathrm{a}}$ Câmara de Direito Público, Relator Urbano Ruiz, julgado em 19 de setembro de 2011;

- Processo $n^{\circ}$ 9133231-92.2008.8.26.0000, 10 Câmara de Direito Público, Relator Antonio Celso Aguilar Cortez julgado em 25 de julho de 2011;

- Processo $n^{\circ}$ 9067182-35.2009.8.26.0000, $11^{\mathrm{a}}$ Câmara de Direito Público, Relator Aroldo Mendes Viotti julgado em 12 de dezembro de 2011;

- Processo $n^{0}$ 9058824-81.2009.8.26.0000, $11^{\text {a }}$ Câmara de Direito Público, Relator Francisco Vicente Rossi julgado em 30 de março de 2009;

- Processo $n^{\mathrm{o}}$ 0276957-78.2011.8.26.0000, $11^{\mathrm{a}}$ Câmara de Direito Público, Relator Oscild de Lima Júnior julgado em 05 de dezembro de 2011; 
- Processo $n^{\circ}$ 0011057-70.2011.8.26.0053, $11^{\mathrm{a}}$ Câmara de Direito Público, Relator Ricardo Dip julgado em 05 de dezembro de 2011;

- Processo $n^{\circ}$ 0568385-94.2010.8.26.0000, $11^{\mathrm{a}}$ Câmara de Direito Público, Relator Aliende Ribeiro julgado em 25 de julho de 2011;

- Processo $n^{\circ}$ 0016040-49.2010.8.26.0053, $11^{\mathrm{a}}$ Câmara de Direito Público, Relator Pires de Araújo julgado em 18 de abril de 2011;

- Processo $n^{\circ}$ 0005334-95.2011.8.26.0562, 12a Câmara de Direito Público, Relator Edson Ferreira julgado em 07 de dezembro de 2011;

- Processo $n^{\circ}$ 0248650-85.2009.8.26.0000, $12^{\mathrm{a}}$ Câmara de Direito Público, Relator Osvaldo de Oliveira julgado em 07 de dezembro de 2011;

- Processo $\mathrm{n}^{\mathrm{o}}$ 0032205-85.2010.8.26.0114, $12^{\mathrm{a}}$ Câmara de Direito Público, Relator Ribeiro de Paula julgado em 31 de agosto de 2011;

- Processo $n^{0}$ 0043131-51.2009.8.26.0114, $12^{\mathrm{a}}$ Câmara de Direito Público, Relator Burza Neto julgado em 18 de janeiro de 2012;

- Processo $n^{0}$ 0024546-14.2010.8.26.0053, $12^{\mathrm{a}}$ Câmara de Direito Público, Relator Wanderley José Federighi julgado em 08 de junho de 2011;

- Processo $n^{\circ}$ 0039889-61.2010.8.26.0114, 13ª Câmara de Direito Público, Relator Luciana Bresciani julgado em 26 de outubro de 2011;

- Processo $n^{\circ}$ 0033688-53.2010.8.26.0405, $13^{\mathrm{a}}$ Câmara de Direito Público, Relator Borelli Thomaz julgado em 11 de janeiro de 2012;

- Processo $n^{0}$ 0158624-70.2011.8.26.0000, $13^{\mathrm{a}}$ Câmara de Direito Público, Relator Peiretti de Godoy julgado em 21 de setembro de 2011;

- Processo $n^{\circ}$ 0022374-71.2010.8.26.0224, $13^{\mathrm{a}}$ Câmara de Direito Público, Relator Ferraz de Arruda julgado em 13 de abril de 2011;

- Processo $n^{\mathrm{o}}$ 0003596-81.2010.8.26.0053, 13 ${ }^{\mathrm{a}}$ Câmara de Direito Público, Relator Ivan Sartori julgado em 25 de maio de 2011;

- Processo $n^{\circ}$ 9102428-39.2002.8.26.0000, $14^{\mathrm{a}}$ Câmara de Direito Público, Relator Marino Neto julgado em 01 de dezembro de 2011;

- Processo $n^{\circ}$ 0172734-16.2007.8.26.0000, $14^{\mathrm{a}}$ Câmara de Direito Público, Relator Geraldo Xavier julgado em 16 de junho de 2011;

- Processo $n^{\circ}$ 9054968-90.2001.8.26.0000, 14ª Câmara de Direito Público, Relator Rodolfo César Milano julgado em 15 de setembro de 2011; 
- Processo $n^{0}$ 0099491-83.2000.8.26.0000, 14ª Câmara de Direito Público, Relator Rodrigo Enout julgado em 30 de março de 2006;

- Processo $n^{\mathrm{o}}$ 0050394-75.2004.8.26.0000, 15ª Câmara de Direito Público, Relator Eutálio Porto julgado em 29 de julho de 2010;

- Processo $n^{\mathrm{o}}$ 0387229-13.2009.8.26.0000, 15 Câmara de Direito Público, Relator Silva Russo julgado em 12 de novembro de 2011;

- Processo $\mathrm{n}^{\mathrm{o}}$ 0048118-27.2011.8.26.0000, $15^{\mathrm{a}}$ Câmara de Direito Público, Relator Arthur Del Guércio julgado em 06 de outubro de 2011;

- Processo $n^{\circ}$ 0146869-59.2005.8.26.0000, 15 Câmara de Direito Público, Relator Erbetta Filho julgado em 09 de dezembro de 2010;

- Processo $\mathrm{n}^{\mathrm{o}}$ 0009367-68.2011.8.26.0000, $18^{\mathrm{a}}$ Câmara de Direito Público, Relator Roberto Martins de Souza julgado em 26 de maio de 2011;

- Processo $n^{\circ}$ 0145178-34.2010.8.26.0000, $18^{a}$ Câmara de Direito Público, Relatora Beatriz Braga julgado em 31 de março de 2011;

- Processo $n^{\circ}$ 0282417-80.2010.8.26.0000, $18^{\mathrm{a}}$ Câmara de Direito Público, Relatora Osvaldo Capraro julgado em 02 de dezembro de 2010;

- Processo $n^{\circ}$ 0147482-74.2008.8.26.0000, $18^{\mathrm{a}}$ Câmara de Direito Público, Relator J. Martins julgado em 25 de fevereiro de 2010. 